Universidade de São Paulo

Faculdade de Medicina de Ribeirão Preto

\title{
2019
}

\section{INFLUÊNCIA DO GLICOGÊNIO MUSCULAR SOBRE A ORIGEM DA FADIGA EM DIFERENTES DOMÍNIOS DE INTENSIDADE}

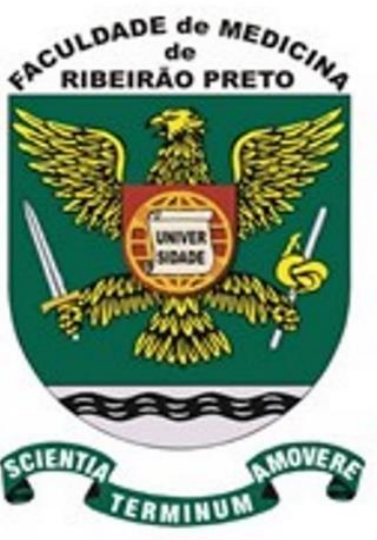

Carlos Augusto Kalva Filho 


\section{Versão Corrigida}

CARLOS AUGUSTO KALVA FILHO

\section{INFLUÊNCIA DO GLICOGÊNIO MUSCULAR SOBRE A ORIGEM DA FADIGA EM DIFERENTES DOMÍNIOS DE INTENSIDADE}

Tese apresentada à Faculdade de Medicina de Ribeirão Preto da Universidade de São Paulo, para obtenção do título de Doutor em Ciências pelo Programa de pós-graduação em Reabilitação e Desempenho Funcional.

Área de Concentração: Fisioterapia

Orientador: Prof. Dr. Marcelo Papoti

Ribeirão Preto 
Kalva-Filho, Carlos Augusto

Influência do glicogênio muscular sobre a origem da fadiga em diferentes domínios de intensidade/ Carlos Augusto Kalva Filho; Orientador Dr. Marcelo Papoti - Ribeirão Preto, São Paulo, 2019.

191p. il.,

Tese (Doutorado) - Faculdade de Medicina de Ribeirão Preto da Universidade de São Paulo/USP - Programa de Pós-Graduação em Reabilitação e Desempenho Funcional, Área de concentração: Fisioterapia.

1. Fadiga central, 2. Fadiga periférica, 3. Glicogênio muscular, 4. Triptofano 


\section{DedicatóRia}


Dedico este trabalho a toda sociedade brasileira. Sem parecer preciosista em relacionar os dados aqui expostos a vida de toda população, expresso minha obrigação em agradecer e dedicar meus estudos a todos que contribuíram direta ou indiretamente para a manutenção do ensino superior oferecido de maneira pública. Embora para sociedade atual a real importância do ensino superior seja muitas vezes obscura, os novos profissionais, os serviços prestados e as pesquisas que surgem desta modalidade de ensino são, sem dúvida nenhuma, essenciais para a manutenção e evolução da sociedade. Dessa forma, do meu ponto de vista, nada mais justo do que eu registrar neste espaço meus agradecimentos a sociedade brasileira. Espero contribuir futuramente para a formação de profissionais gabaritados para o ensino da Educação Física e produzir pesquisas que influenciem relevantemente esta sociedade, a qual eu tanto devo. 
Agradecimentos 
Primeiramente, agradeço a você que se interessou em ler este trabalho. Espero contribuir ao menos um pouco para a sua jornada, seja ela qual for.

Gostaria de começar os agradecimentos por meu pai Carlos Augusto Kalva, minha mãe Marlene Gomes Kalva e as minhas irmãs Anne Caroline Kalva e Danielle Cristyane Kalva Borato, é praxe, mas farei com a maior alegria e satisfação do mundo, pois não estaria aqui sem todos os sacrifícios que vocês fizeram por mim. Meu paizinho amado, só Deus sabe o tamanho e o porquê do fardo que o senhor trouxe para esta encarnação, como fiz anteriormente, te agradeço por nunca ter desistido da vida! Peço desculpas por não estar ao seu lado sempre que você precisou, me desculpe por não poder mais pescar com o senhor todo final de semana. Você é e sempre será um exemplo de força, esperteza, honestidade e humildade, ao qual me espelharei para o resto da minha vida. Minha mãezinha, ôô minha mãezinha tão amada, te agradeço por toda a devoção que você demonstrou e demonstra para ser mãe e agora avó. Não tenho palavras para agradecer por você ser essa mulher de uma fibra sem igual, que nunca mediu esforços para que eu tivesse tudo do bom e do melhor, com conforto e muitas regalias. Acredite minha mãezinha, tudo que eu precisava era estar ao seu lado todos os dias da minha vida, pro resto da minha vida. Peço desculpas por não conseguir expressar meus problemas, por não ter ligado todos os dias para a senhora, por ter deixado você tão aflita por todos estes anos, espero que você entenda, com todo amor que eu sei que você tem no seu peito. Além destes agradecimentos, também gostaria de expressar minha gratidão por todas as oportunidades que vocês me possibilitaram desde estudar nas melhores escolas até as vivências cognitivas e motoras, como brincar na rua e permitir que eu montasse minha própria bicicletaria no porão da nossa casa. Anne minha irmã linda, agradeço por tudo que você tem feito ao longo destes anos, por estar ao lado dos nossos pais, ajudando no que eles mais precisavam. Você renunciou muitas coisas por eu não estar presente para dividir os problemas, peço desculpas por isso, do 
fundo do meu coração. Obrigado por todas as vezes que você foi atenciosa comigo, desde me arrumar para escola até comprar as passagens para eu voltar, sou eternamente grato pelo seu apoio como irmã. Dani, devo a você muito do que sou hoje como estudante, muito obrigado por toda ajuda intelectual e emocional que você me deu ao longo destes anos, não tenho como mensurar a diferença que isso faz na minha vida. Preciso novamente agradecer a você e ao Ricardo por terem aceitado o desafio de conceber a Camille, obrigado por terem colocado nossas vidas em outro patamar. Camille, espero que um dia você encontre este documento e entenda o porquê do seu tio não estar presente na melhor fase da sua vida! Me desculpe por isso, minha princesa.

A vida é feita de renuncias! Não estar com vocês é, sem dúvida, a que mais me dói. Espero o perdão de vocês por todas as decepções que eu possa ter causado. Eu Amo muito todos vocês!

Não posso deixar de agradecer a todos os amigos que fiz em Ribeirão Preto nessa jornada. Sem risco de esquecer alguém, agradeço a todos sem exceção. Obrigado por terem me recebido de braços abertos nessa cidade tão maravilhosa. Em especial aos amigos que convivi no GECIFEX, obrigado por me aguentar esses anos e me perdoem pelas inconveniências constantes. Espero ter contribuído para a formação de vocês pelo menos um pouquinho, assim retribui o tanto que vocês me ensinaram ao longo destes anos. Dedico muito deste trabalho ao Nayan Xavier Ribeiro (In memoriam), que nos deixou no meio desta jornada. Espero que se sinta bem, onde quer que você esteja, meu amigo. Também preciso agradecer ao nosso técnico de laboratório Marçal Vieira de Almeida, que tem proporcionado uma maior agilidade em nossos procedimentos, sempre com uma prontidão admirável. Realmente, muito obriga tudo, principalmente por não serem apenas um laboratório, mas sim, uma república.

Deixo aqui também meus agradecimentos especiais ao meu orientador, Prof. Dr. Marcelo Papoti. Acredito que você não tenha total ideia da transformação que proporciona no ambiente 
e nas pessoas que estão ao seu redor. Você é um exemplo de profissionalismo, sem perder a honra e o respeito ao próximo. Realmente Marcelo, aqui faz-se outra praxe, mas eu gostaria de agradecer por todas as oportunidades que você me deu ao longo destes anos. Tentei aproveitálas ao máximo, espero não ter decepcionado na maioria delas, afinal o importante é o saldo. Peço desculpas pelas vezes em que deixei a desejar. Devo-lhe tanto que acredito não precisar falar, mas, como este espaço permite redundâncias: Conte sempre comigo! 


\section{Apoio financeiro}


Esta tese teve o apoio financeiro da Fundação de Amparo à Pesquisa do Estado de São Paulo (FAPESP) (n 16/09339-9). Além disso, agradeço o apoio da Coordenação de Aperfeiçoamento de Pessoal de Nível Superior - Brasil (CAPES), ao Programa de Reabilitação e Desempenho Funcional da Faculdade de Medicina de Ribeirão Preto - Código de financiamento 001. 
Apresentação 
Atualmente o modelo tradicional de elaboração de uma tese tem sido substituído pelo modelo "escandinavo", principalmente pela objetividade das informações apresentadas. Embora o modelo escandinavo facilite a transição entre a tese completa e os artigos que serão publicados, acredito que muitas informações pertinentes são redigidas de maneira superficial em meio aos seus "pré-prints". Assim, a história relacionada a cada artigo fica restrita apenas ao autor e ao orientador da tese, que ficam impossibilitados de contar seus erros e acertos ao longo do processo. Em outras palavras, como frequentemente comentamos em nosso laboratório e com outros grupos de estudo, a tese apresentada no modelo "escandinavo" diminui o "romantismo" deste documento tão importante.

Por outro lado, o modelo tradicional de elaboração de uma tese, caso escrito de maneira prolixa, pode tornar sua leitura monótona e as informações pouco aprazíveis aos interessados. A grande distância entre a forma de apresentação da tese e os artigos científicos que serão publicados, também representa uma grande limitação do modelo tradicional. Na minha opinião, estes são os principais motivos que explicam o exponencial declínio no número de teses escritas com este modelo.

Buscando extrair as principais vantagens destes modelos, a presente tese foi confeccionada utilizando um modelo híbrido, composto por um documento principal e outro auxiliar. O documento principal assemelha-se ao modelo escandinavo, onde apresentamos os procedimentos metodológicos aplicados e os resultados obtidos ao longo dos delineamentos, de uma maneira objetiva. Este documento contém todas as informações necessárias sobre as atividades desenvolvidas para responder nossa pergunta central. Entretanto, caso você tenha dúvidas sobre os procedimentos aplicados você pode recorrer ao documento auxiliar, onde descrevemos com riqueza de detalhes os problemas experimentais observados, os meios e métodos que utilizamos para resolvê-los e algumas padronizações importantes para a robustez 
dos nossos dados.

O documento principal é composto por cinco capítulos. No primeiro capítulo a introdução e os objetivos foram demonstrados de uma maneira bastante direta e objetiva. No segundo capítulo estão apresentadas todas as padronizações prévias, instrumentais e metodológicas, que julgamos necessárias para a realização dos experimentos propostos. Nos dois próximos capítulos, os principais resultados sobre o tema central desta tese foram apresentados. Por fim, as considerações finais sobre nossos resultados estão apresentadas no quinto capítulo. Perceba que a tradicional revisão da literatura não foi contemplada nos capítulos do documento principal, sendo inserida como tópico do documento auxiliar.

É importante salientar que o documento principal foi confeccionado a partir do modelo escandinavo, possibilitando que o documento auxiliar seja totalmente ignorado. Além disso, caso você tenha interesse em informações específicas no documento auxiliar, o documento principal possui Hyperlinks que levarão ao assunto desejado, basta clicar sobre o link. Assim, o documento auxiliar não precisa ser lido na íntegra e, embora a presente tese seja composta por 190 páginas, você pode optar em ler apenas as 71 páginas do documento principal.

Desejo-lhe uma boa leitura e fico a disposição para as possíveis dúvidas relacionadas a dinâmica do presente documento. 
Resumos e SUMÁRIO 
KALVA-FILHO, C.A. Influência do glicogênio muscular sobre a origem da fadiga em diferentes domínios de intensidade. [Tese]. Ribeirão Preto: Universidade de São Paulo, Faculdade de Medicina de Ribeirão Preto, 2019. $191 \mathrm{f}$.

\section{RESUMO}

Durante esforços com baixas quantidades de glicogênio muscular (B-Glic), a fadiga é classicamente relacionada a fatores periféricos, como a indisponibilidade energética. Entretanto, a situação de B-Glic induz alterações sistêmicas, as quais podem levar a uma diminuição da ativação muscular pelo sistema nervoso (i.e., fadiga central). Considerando estas duas vertentes de pensamento, a presente tese teve como objetivo investigar as possíveis influências do glicogênio muscular sobre a origem da fadiga em diferentes domínios de intensidade. Para testar as diferentes origens da fadiga, utilizamos técnicas como a twitch interpolation (TI) e a estimulação magnética trascraniana. Além disso, testamos se a situação de B-Glic pode ser responsável pela diminuição na ativação dos motoneurônios (i.e., fadiga central), principalmente pela ação do triptofano ( $\mathrm{TrP})$ circulante. Basicamente buscamos avaliar a origem de fadiga em esforços com B-Glic, induzida por exercício prévio, e após a recuperação deste substrato (R-Glic), por meio de dieta com altos índices de carboidrato. No primeiro experimento, 11 participantes foram submetidos a um esforço de depleção, $24 \mathrm{~h}$ de recuperação com aplicação de solução contendo (Maltodextrina 10\%; R-Glic) ou não (placebo, B-Glic) carboidratos, seguida de esforço intermitente de alta intensidade $\left(6 \times 1\right.$ min a $120 \%$ do $\mathrm{VO}_{2 \mathrm{PICO}}$, separados por 3 min de intervalo passivo). Neste experimento, o conteúdo de glicogênio foi estimado por ultrassom. Os principais resultados demonstram que i) o glicogênio é preservado em esforços com B-Glic e ii) a fadiga tem origem periférica independentemente do conteúdo prévio de glicogênio. Em outro experimento investigamos a origem da fadiga em esforços prolongados e suas relações com as concentrações sanguíneas de TrP, desta vez realizamos um período de 5 dias para a depleção do glicogênio (exercícios e dieta com baixas quantidades de 
carboidratos $\left.\left(0,3 \pm 0,2 \mathrm{~g} \cdot \mathrm{Kg}^{-1} \cdot \mathrm{dia}^{-1}\right)\right)$. A situação R-Glic foi induzida por três dias de descanso e dieta com elevadas quantidades de carboidrato $\left(4,5 \pm 1,7 \mathrm{~g} \cdot \mathrm{Kg}^{-1} \cdot \mathrm{dia}^{-1}\right)$. Neste experimento as quantidades de glicogênio foram determinadas por meio de biópsia muscular (B-Glic: 0,6 0 0,2 mg.100mg ${ }^{-1}$; B-Glic: $\left.4,5 \pm 1,6 \mathrm{mg} .100 \mathrm{mg}^{-1} ; \mathrm{p}=0,001\right)$. O esforço realizado a $80 \%$ do $\mathrm{VO}_{2 \mathrm{PICO}}$ (2x15 min, seguido de um esforço exaustivo nesta intensidade; E30Tlim) demonstrou uma pronunciada fadiga periférica em esforços com B-Glic, o que não ocorreu para o esforço RGlic. As concentrações de TrP foram correlacionadas com parâmetros de fadiga central ( $\mathrm{r}=-$ 0,87) somente na situação B-Glic. Além disso, a variação percentual da força evocada pelos estímulos magnéticos da EMT foi significativamente correlacionada a variação percentual do $\operatorname{TrP}(r=0,89)$. O esforço de maior duração e menor intensidade $\left(2 \times 20\right.$ min a $70 \%$ do $\mathrm{VO}_{2 \mathrm{PICO}}$, seguido de um exercício exaustivo a $80 \%$ do $\mathrm{VO}_{2 \mathrm{PICO}}$; E40Tlim), apresentou origem de fadiga periférica mais pronunciada quando realizado com B-Glic. Os resultados da técnica de EMT demonstraram que a situação R-Glic induziu significativas diminuições na amplitude, no tempo entre os picos e na força evocada pelos estímulos magnéticos. Significativas correlações foram observadas entre o tempo de silencio após o segundo esforço constante e as concentrações de $\operatorname{TrP}(\mathrm{r}=0,94)$. O tempo de pico a pico no repouso também foi correlacionado com as concentrações de $\operatorname{Tr} P(r=0,93)$. Desse modo, pode-se concluir que a origem da fadiga em esforços com diferentes quantidades de glicogênio é influenciada pela intensidade do exercício realizado. Especificamente, a fadiga em esforços com B-Glic tem origem periférica em esforços intermitentes de alta intensidade e nos esforços de moderada duração apresenta um caráter misto (E30Tlim) ou periférico (E40Tlim). A origem central da fadiga emerge apenas no E30Tlim, quando o esforço é realizado na situação R-Glic.

Palavras - chave: Fadiga central, Fadiga periférica, Glicogênio muscular, Triptofano. 
KALVA-FILHO, C.A. Influence of muscle glycogen on the origin of fatigue in different domains of intensity. [Thesis]. Ribeirão Preto: University of São Paulo, Ribeirão Preto Medical School, 2019. 191f.

\section{ABSTRACT}

During efforts with low muscle glycogen (B-Glic), fatigue is classically related to peripheral factors, such as energy unavailability. However, the B-Glic situation also induces systemic changes, which can decrease the muscle activation by the nervous system (i.e., central fatigue). Considering these two strands of thought, this thesis aimed to investigate the possible influences of muscle glycogen on the origin of fatigue in different domains of intensity. To test the different origins of fatigue, we used techniques such as twitch interpolation (TI) and transcranial magnetic stimulation (TMS). In addition, we tested whether the B-Glic situation may be responsible for the decrease in the activation of the motoneurons (i.e., central fatigue), mainly by the action of circulating tryptophan $(\mathrm{TrP})$. Basically, we tried to evaluate the origin of fatigue in efforts with B-Glic, induced by previous exercise, and after the recovery of this substrate (RGlic), through a diet with high carbohydrate levels. In the first experiment, 11 participants underwent depletion effort, 24-hour with solution application containing (10\% Maltodextrin; R-Glic) or not (placebo, B-Glic) carbohydrates, and a high-intensity intermittent effort (6x1min to $120 \%$ of $\mathrm{VO}_{2 \mathrm{PICO}}$, separated by 3 min of passive recovery). In this experiment, the glycogen content was estimated by ultrasound. The main results demonstrate that i) glycogen is preserved in efforts with B-Glic and ii) the fatigue has peripheral origin regardless of the previous glycogen content. In another experiment we investigated the origin of fatigue in prolonged exertion and its relationships with the blood concentrations of $\mathrm{TrP}$, this time we performed a 5day period for glycogen depletion (exercises and diet with low amounts of carbohydrates $(0.3$ $\pm 0,2 \mathrm{~g} \cdot \mathrm{kg}^{-1}$. Day $\left.\left.{ }^{-1}\right)\right)$. The R-Glic situation was induced by three days of rest and diet with high amounts of carbohydrate $\left(4.5 \pm 1.7 \mathrm{~g} \cdot \mathrm{Kg}^{-1} \cdot \mathrm{day}^{-1}\right)$. In this experiment, glycogen levels were determined by muscle biopsy (B-Glic: $0.6 \pm 0.2 \mathrm{mg} .100 \mathrm{mg}^{-1}$; B-Glic: $4.5 \pm 1.6 \mathrm{mg} .100 \mathrm{mg}^{-1}$; $\mathrm{p}$ 
$=0.001)$. The effort performed at $80 \%$ of $\mathrm{VO}_{2 \mathrm{PEAK}}(2 \mathrm{x} 15 \mathrm{~min}$, followed by an exhaustive effort at this intensity, E30Tlim) demonstrated a pronounced peripheral fatigue in B-Glic efforts, which did not occur for the R-Glic effort. Concentrations of $\operatorname{TrP}$ were correlated with parameters of central fatigue $(r=-0.87)$ only in the B-Glic situation. In addition, the percentage variation of the force evoked by the TMS magnetic stimuli was significantly correlated with the percentage variation of the $\operatorname{TrP}(r=0.89)$. The longer effort with lower intensity $(2 \times 20 \mathrm{~min}$

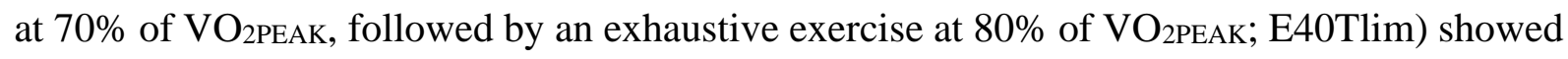
a more pronounced peripheral fatigue when performed with B-Glic. The results of the TMS technique demonstrated that the R-Glic situation induced significant decreases in amplitude, time between peaks and in the force evoked by magnetic stimuli. Significant correlations were observed between the time of silence after the second constant effort and the concentrations of $\operatorname{Tr} \mathrm{P}(\mathrm{r}=0.94)$. The peak-to-peak time at rest was also correlated with $\operatorname{Tr} \mathrm{P}$ concentrations $(\mathrm{r}=$ 0.93). Thus, it can be concluded that the origin of fatigue in efforts with different amounts of glycogen is influenced by the intensity of exercise performed. Specifically, fatigue in B-Glic efforts has peripheral origin in intermittent high-intensity efforts and in moderate-duration efforts has a mixed (E30Tlim) or peripheral (E40Tlim) character. The central origin of the fatigue emerges only in the E30Tlim, when the effort is realized in the R-Glic situation.

Keywords: Central fatigue, Peripheral fatigue, Muscle glycogen, Tryptophan. 


\section{SUMÁRIO}

DOCUMENTO PRINCIPAL 20

CAPÍTULO 1 - INTRODUÇÃO E OBJETIVOS .......................................................... 1

CAPÍTULO 2 - PADRONIZAÇÕES INSTRUMENTAIS E METODOLÓGICAS ............ 5

CAPÍTULO 3 - GLICOGÊNIO MUSCULAR E A ORIGEM DA FADIGA EM

ESFORÇOS INTERMITENTES DE ALTA INTENSIDADE: UM ESTUDO

RANDOMIZADO, DUPLO-CEGO E CONTROLADO POR PLACEBO

10

CAPÍTULO 4 - ORIGEM DA FADIGA EM ESFORÇOS DE DURAÇÃO MODERADA REALIZADOS COM DIFERENTES CONTEÚDOS DE GLICOGÊNIO MUSCULAR .. 31

CAPÍTULO - 5 CONSIDERAÇÕES E CONCLUSÕES DA TESE. 69

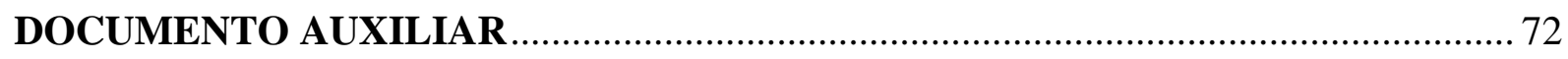

I - REVISÃO DA LITERATURA (voltar ao documento principal) .................................. 72

II - PADRONIZAÇÃO DO ERGÔMETRO PARA EXTENSÃO DE DINÂMICA DE

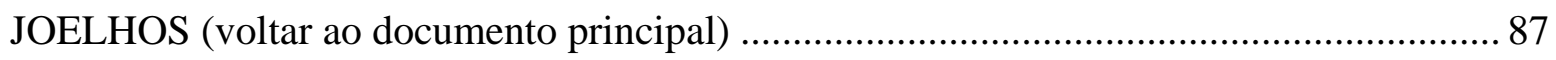

III - RESPOSTAS FISIOLÓGICAS E PADRONIZAÇÃO DO ESFORÇO NO

ERGÔMETRO PARA EXTENSÃO DE DINÂMICA DE JOELHOS .

IV - A PADRONIZAÇÃO DO ESFORÇO PARA DEPLEÇÃO DO GLICOGÊNIO

MUSCULAR (voltar ao Capítulo 2) (Voltar ao Capítulo 4) .............................................. 134

V - A PADRONIZAÇÃO DAS BIÓPSIAS E DETERMINAÇÃO DO GLICOGÊNIO

MUSCULAR (voltar ao documento principal)............................................................. 150

VI - A TÉCNICA DE ESTIMULAÇÃO MAGNÉTICA TRANSCRANIANA (voltar ao

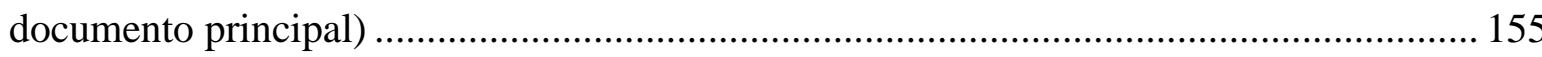

VII - A DETERMINAÇÃO DO TRIPTOFANO SANGUÍNEO TOTAL (voltar ao

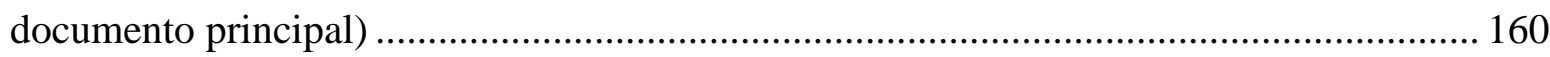

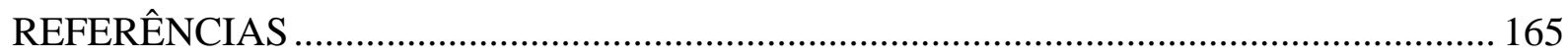




\section{Documento PRINCIPAL}




\section{CAPÍtulo 1 - Introdução e OBJetivos}

Classicamente, a fadiga é definida como a incapacidade de manutenção e/ou produção da força esperada durante o exercício [1,2], podendo ser relacionada com alterações periféricas (i.e. muscular) ou centrais (i.e. sistema nervoso) [3].

A fadiga central é relacionada aos mecanismos de feedback observados entre o sistema nervoso e os músculos utilizados durante o exercício, podendo ser de nível cortical ou espinhal [4]. Independentemente do nível onde a fadiga central ocorre, podemos caracteriza-la pela diminuição da atividade muscular induzida pelo sistema nervoso [4]. Diferentemente, os fatores que caracterizam a fadiga periférica estão relacionados ao processo excitação-contração muscular (e.g. despolarização ineficiente tanto do sarcolema como do retículo sarcoplasmático), a indisponibilidade de substratos energéticos e ao acúmulo de metabólitos [2]. Neste contexto, identificar os processos centrais e periféricos para a fadiga em diferentes esforços, propicia o desenvolvimento de diferentes estratégias para aumentar a tolerância ao exercício, o que é fundamental para o desempenho.

Frequentemente durante o treinamento de várias modalidades esportivas, os atletas realizam esforços com baixas quantidades de glicogênio muscular (B-Glic), o que diminui significativamente a tolerância ao exercício [5-7]. As quantidades de glicogênio muscular podem ser alteradas durante a rotina de treinamento por estratégias de alimentação $[8,9]$, por esforços agudos com diferentes intensidades $[6,7,10-18]$ e por dias consecutivos de treinamento com elevada carga [5]. Além disso, o glicogênio é continuamente depletado em esforços de longa duração $[9,19]$, sendo de extrema importância para o desempenho que o atleta tolere o exercício realizado com baixas quantidades deste substrato. Considerando estes fatores, o conhecimento sobre os processos centrais e periféricos que influenciam a fadiga em 
esforços com B-Glic, torna-se de extrema importância tanto para o desempenho como para a organização dos estímulos treinamento.

O declínio na tolerância ao exercício observado em esforços com B-Glic atualmente é relacionado a fatores periféricos de fadiga (i.e. quantidades insatisfatórias de ATP tanto para a contração muscular como para a reabsorção ativa do cálcio) [5-7]. De modo paradoxal, foi demonstrado que mesmo no momento da exaustão, as concentrações de glicogênio não estão completamente esgotadas $[2,10,11,20]$. Além disso, as quantidades de ATP são mantidas durante todo o exercício, inclusive no momento da exaustão (i.e. degradação do ATP < 30\% em relação aos valores de repouso) [2, 19]. Estes resultados demonstram que em esforços com B-Glic, a fadiga precoce (i.e. < tempo até a exaustão; Tlim) parece não ser completamente explicada pela indisponibilidade de energia.

Entretanto, embora os primeiros estudos sobre as influências da disponibilidade de carboidratos tenham surgido desde 1920, estudos recentes tem demonstrado que a diminuição do conteúdo de glicogênio muscular pode ter efeitos tanto locais como sistêmicos [7, 17, 21]. Dentre estes efeitos sistêmicos podemos destacar a maior liberação de interleucina-6 (IL-6), que além de suas funções relacionadas ao processo inflamatório, também está relacionada a uma maior sensação de fadiga e redução da capacidade de concentração, o que pode levar a diminuições na ativação muscular [22-24]. Outro efeito sistêmico da B-Glic é o aumento das catecolaminas circulantes, o que leva a elevação das concentrações séricas de ácidos graxos livres (AgL), aumentando a quantidade sanguínea de triptofano livre (TrP-L) [25-27]. Este aminoácido atravessa a barreira hematoencefálica e desencadeia a formação cerebral de serotonina, o que possivelmente está relacionado a uma diminuição da atividade dos motoneurônios durante o exercício [27, 28]. Embora a influência do TrP-L seja estudada por meio de delineamentos com suplementação, este mecanismo fisiológico é apenas uma hipótese 
em esforços B-Glic.

Desse modo, considerando estes efeitos sistêmicos, outra possível explicação para o comprometimento do desempenho em esforços com B-Glic pode estar relacionada a fadiga central $[29,30]$. Neste tipo de esforço, observa-se um aumento da atividade simpática sobre o coração [31-33], provavelmente devido à elevação nos níveis de catecolaminas [34]. Este panorama fisiológico pode desencadear a função protetora do sistema nervoso central, conhecida como "modelo de governador central" [29, 30]. De acordo com este modelo, o sistema nervoso diminui a atividade muscular antes do desenvolvimento da fadiga periférica, protegendo órgãos como o cérebro e o coração, que são sensíveis as grandes alterações metabólicas induzidas pelo exercício [29, 30].

Embora o modelo de governador central seja uma teoria parcialmente aceita para explicar a fadiga em várias intensidades [29, 30, 35], sendo considerado um novo paradigma da fisiologia do exercício [36], seus mecanismos fisiológicos ainda são pouco conhecidos. A linha de raciocínio relacionada a uma influência central em esforços com B-Glic foi demonstrada pelo estudo de Rauch et al. [37], que observaram que em um esforço de 60 min o pace foi menor quando os voluntários iniciaram o esforço com a restrição de glicogênio, mas o final da prova, onde os ciclistas aumentam a intensidade de exercício, não foi influenciada. Os autores concluíram que o glicogênio muscular foi preservado ao longo do exercício por mecanismos centrais, principalmente considerando o mesmo desempenho nos minutos finais da prova, o que indica que a capacidade de contração muscular também foi preservada na situação B-Glic. Entretanto, este aporte neural diferenciado na situação B-Glic ainda não foi evidenciado experimentalmente, utilizando técnicas específicas para avaliação da fadiga central e periférica.

Durante a rotina de treinamento, na "vida real", os atletas comumente realizam esforços em várias intensidades, independentemente da distribuição de cargas proposta ou modelo de 
treinamento utilizado [38]. Esforços realizados abaixo da intensidade correspondente ao consumo máximo de oxigênio ( $\mathrm{iVO}_{2 \mathrm{MAX}}$ ), parecem ser influenciados pela quantidade de glicogênio [39, 40]. Considerando que os processos centrais e periféricos para a fadiga parecem ser influenciados pela intensidade em que o exercício é realizado [41], é plausível que a origem da fadiga também seja alterada por esse fator em esforços com B-Glic realizados em diferentes intensidades, o que inda é pouco explorado na literatura.

A partir das informações expostas acima, as quais foram levantadas após uma revisão da literatura (Documento auxiliar I - Revisão da literatura), embora a fadiga periférica seja a resposta mais plausível, é possível que o desempenho em esforços com B-Glic seja comprometido por fatores centrais, o que ainda pode ser modulado pela intensidade do exercício realizado. Entretanto, estas afirmações ainda não foram testadas experimentalmente. Tendo em vista a importância desta informação para o entendimento sobre a tolerância ao exercício, a presente tese foi empenhada em responder a seguinte pergunta central:

Qual é a contribuição dos processos centrais e periféricos para a fadiga em esforços com BGlic realizados em diferentes intensidades?

Assim, transcrevendo nossa pergunta, o principal objetivo desta tese foi investigar a contribuição dos processos centrais e periféricos para a fadiga em esforços com B-Glic realizados em diferentes intensidades.

Especificamente nossos objetivos foram:

$\checkmark$ Determinar o perfil da fadiga em esforços com B-Glic;

$\checkmark$ Determinar como os processos centrais e periféricos relacionados a fadiga podem ser influenciados por diferentes intensidades;

$\checkmark$ Investigar as possíveis relações do TrP sobre o perfil da fadiga em esforços com B-Glic; 


\section{Capítulo 2 - Padronizações Instrumentais e Metodológicas}

Este capítulo tem o objetivo de demonstrar a sequência de procedimentos prévios realizados para que nossa pergunta central fosse respondida, evidenciando em ordem cronológica os desafios metodológicos e os meios que utilizamos para resolvê-los. Todos os procedimentos demostrados a partir deste capítulo foram aprovados pelo comitê de ética em pesquisa da Escola de Educação Física e Esportes de Ribeirão Preto (CAE: 60156116.2.0000.5659).

O primeiro desafio metodológico que enfrentamos leva em consideração a fisiologia muscular envolvida e a logistica de coleta durante o exercício. Em esforços que utilizam vários grupamentos musculares (e.g. corrida, natação e ciclismo), ocorre a sinergia muscular para a manutenção do exercício. Assim, nos experimentos do projeto principal, a ativação muscular pode ser diferente na segunda sessão de exercício, em relação ao padrão de ativação observado na sessão de depleção [42], comprometendo a caracterização da fadiga em esforços com B-Glic (i.e., as fibras avaliadas não foram depletadas).

Para a mensuração dos fatores relacionados a fadiga central e periférica utilizamos as técnicas de Twitch Interpolation (TI) e estimulação magnética transcraniana (EMT) [4, 43-48]. Estas técnicas utilizam estímulos para a determinação dos parâmetros relacionados a fadiga, sendo necessária a mensuração em conjunto da força evocada pelos impulsos e dos sinais captados pela eletromiografia de superfície (EMG). Para isso, integrantes do nosso grupo de pesquisa construíram uma cadeira específica para a caracterização da fadiga em diferentes esforços $[49,50]$. Embora a construção deste aparato tenha facilitado a aplicação da TI, nossa experiência com esta técnica demonstra que são necessários pelo menos dois minutos para o posicionamento do avaliado na cadeira e, consequentemente, para aplicação dos primeiros 
estímulos. Neste contexto, tendo em vista a rápida recuperação dos parâmetros neuromusculares, a utilização de modelos de exercício convencional (e.g. corrida ou ciclismo) pode influenciar a caracterização da fadiga, principalmente pelo tempo entre o avaliado terminar o esforço e a aplicação dos primeiros estímulos.

Considerando estas limitações metodológicas (i.e., sinergia muscular e tempo até aplicação das técnicas), utilizamos o ergômetro de extensão dinâmica de joelhos como modelo de exercício, permitindo que o quadríceps femoral seja o agente motor primário [51]. Este modelo de exercício garante que as respostas relacionadas ao perfil da fadiga foram induzidas por um grupamento muscular com B-Glic, diminuindo as possíveis influências da sinergia muscular durante o exercício [51]. Destacamos ainda que este modelo de exercício permite a aplicação da TI e da EMT no momento da exaustão, com intervalos curtos de pausa entre o termino do exercício e os estímulos (i.e. < 10s), aumentando a fidedignidade das medidas relacionadas a fadiga. Além disso, não ocorre o deslocamento do corpo em relação ao ergômetro, deixando os membros superiores livres para as coletas de sangue venoso e facilitando a determinação das quantidades de glicogênio muscular durante o exercício (i.e. técnica de ultrassom $[52,53]$ e/ou biópsia muscular).

Embora a utilização da extensão dinâmica de joelhos seja a resposta para os desafios científicos observados, o ergômetro necessário não está disponível comercialmente. Diante desta dificuldade, para responder à pergunta central do projeto, o primeiro passo foi a construção de um ergômetro para a extensão dinâmica de joelhos, o qual padronizamos satisfatoriamente (Documento auxiliar II - Padronização do ergômetro). Caso seja de seu interesse, disponibilizamos em nosso canal um vídeo sobre a construção e utilização do ergômetro para extensão dinâmica de joelhos disponível pelo link: https://www.youtube.com/watch?v=EF3zZMMPAPU\&t=7s. 
Além da construção do ergômetro, realizamos uma série de experimentos para confirmar o isolamento do quadríceps femoral, padronizar o melhor modelo de teste incremental e investigar as respostas obtidas durante esforços constantes realizados em várias intensidades (Documento auxiliar III - Respostas fisiológicas). Resumidamente, tivemos êxito em isolar o quadríceps femoral durante um esforço progressivo, o que permitiu a investigação das respostas relacionadas a fadiga em um grupamento muscular que sabidamente está com B-Glic. Outro resultado importante para a continuidade dos nossos experimentos, foi a baixa tolerância de exercício em alguns esforços contínuos e submáximos. De fato, quando o critério de exaustão foi a incapacidade de manter a cadência de $60 \mathrm{rpm}$ por mais de $10 \mathrm{~s}$ consecutivos, os voluntários apresentaram dificuldades para manter esforços acima de $70 \%$ da maior intensidade atingida no teste incremental (iVO2PICO).

Este resultado influenciou diretamente a aplicabilidade do protocolo de depleção apresentado no projeto desta tese, o qual previa a realização de 60 min contínuos a $70 \%$ da iVO 2 PICO. Este novo problema metodológico desencadeou outra série de novos experimentos piloto, os quais culminaram na padronização dos esforços de depleção utilizados durante o delineamento aplicado no Capítulo 3 (Documento auxiliar IV - Padronização da depleção). Além disso, considerando esta baixa tolerância ao exercício constante, optamos por alterar os esforços de interesse nos diferentes domínios de intensidade. O projeto inicial previa a realização de esforços constantes, onde o tempo até a exaustão (Tlim) seria o principal índice de desempenho avaliado nos diferentes domínios de intensidade. Após estes experimentos preliminares, fixamos um volume a ser cumprido em cada esforço de interesse, onde pequenos ajustes na intensidade podem ocorrer, assim como padronizamos durante o esforço de depleção, priorizando o cumprimento do volume proposto.

Somente após todos estes experimentos piloto, considerando suas padronizações e 
resultados pertinentes, aplicamos os delineamentos utilizados para responder nossa pergunta central. Assim os próximos capítulos descrevem nossa investigação sobre a origem da fadiga em esforços intermitentes de alta intensidade e durante esforços de longa duração (> 30 min). A Figura 1 esquematiza passos experimentais adotados nesta tese.

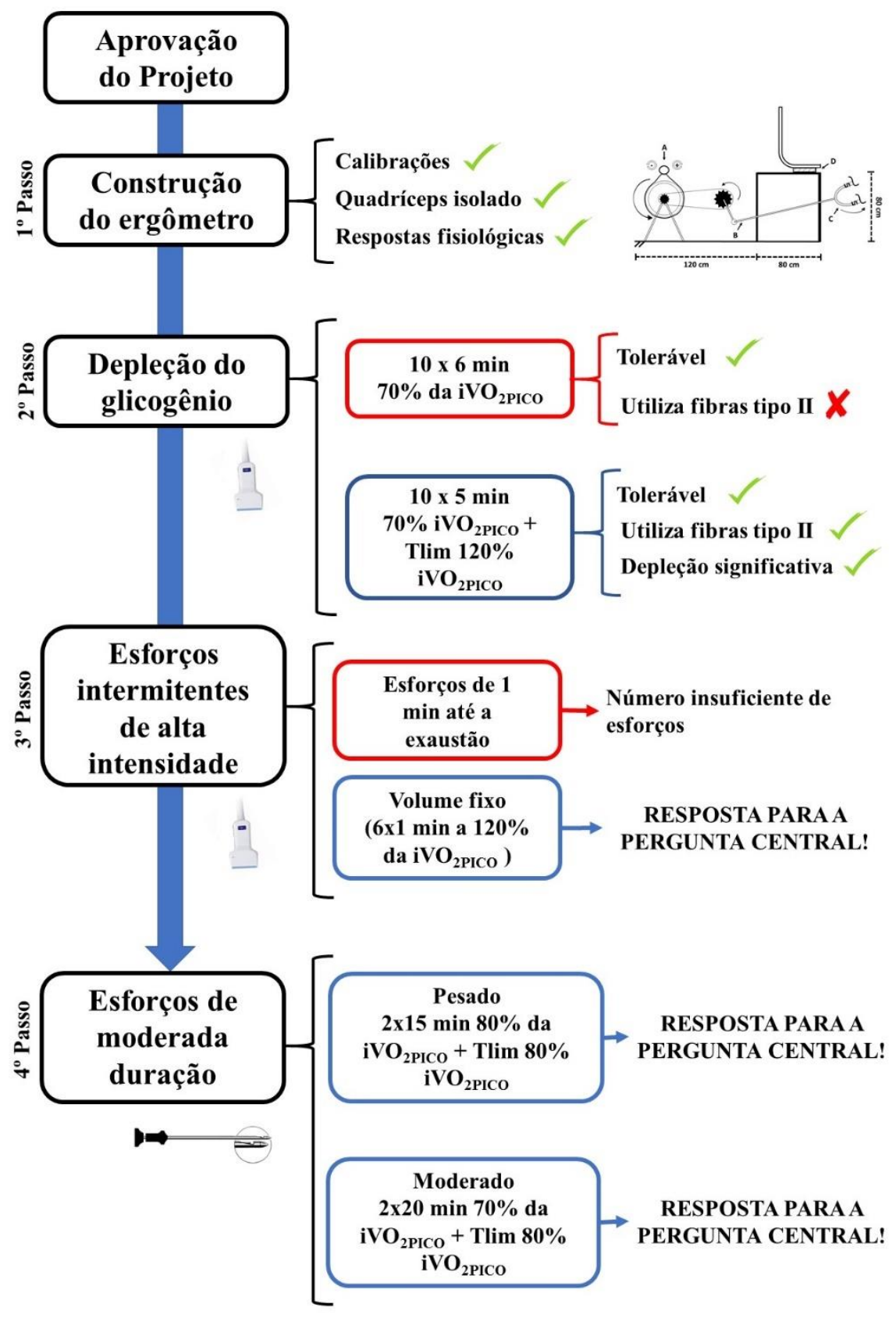

Figura 1. Fluxograma dos principais eventos ocorridos desde a aprovação do projeto principal pela FAPESP até a realização dos últimos experimentos relacionados a nossa pergunta central. 
As tentativas que apresentaram problemas durante a execução estão em destaque vermelho, sendo os procedimentos utilizados para responder à pergunta central destacados em azul.

estimativa do conteúdo de glicogênio por meio de imagens de ultrassom; $=\longrightarrow$ : extração de tecido por meio da técnica de biópsia muscular;

Nota: Resumidamente, o primeiro "grande passo" foi a construção de um ergômetro específico para a extensão dinâmica de joelhos, o que foi realizado com êxito. Tivemos uma preocupação especial com o modelo de exercício que seria utilizado para a depleção do glicogênio muscular, o que nos levou a testar dois protocolos diferentes (Segundo passo). Embora o primeiro tenha sido bem suportado, não contemplava a depleção das fibras tipo II. Assim, o modelo proposto na segunda tentativa foi o escolhido para os próximos passos da presente tese, principalmente por adicionar um esforço até a exaustão ao final da depleção. $\mathrm{O}$ estudo da fadiga com diferentes quantidades de glicogênio ocorreu primeiramente em esforços intermitentes de alta intensidade, onde a primeira tentativa foi realizar inúmeros esforços até que o participante não fosse capaz de sustentar a intensidade pré-estabelecida (Terceiro passo). Como os participantes apresentaram uma elevada variabilidade na quantidade dos esforços, decidimos fixar o volume de esforços, o que possibilitou a observação das primeiras respostas à pergunta central deste projeto. Até este momento da pesquisa, as quantidades de glicogênio muscular foram estimadas por meio de imagens de ultrassom. Entretanto, tivemos uma indisponibilidade de equipamentos. Com isso, decidimos utilizar a técnica de biópsia muscular para a determinação das quantidades de glicogênio (Quarto passo). Assim, foi possível a investigação sobre as influências das quantidades de glicogênio muscular sobre o perfil da fadiga, agora, em esforços de moderada duração. 


\section{Capítulo 3 - Glicogênio muscular e a origem da FADIGA EM ESFORÇOS INTERMITENTES DE ALTA INTENSIDADE: UM ESTUDO RANDOMIZADO, DUPLO-CEGO E CONTROLADO POR PLACEBO}

\section{BACKGROUND}

A intensidade do exercício influência tanto na magnitude de depleção do glicogênio como no tipo de fibra em que este substrato será depletado [10-12, 54]. Gollnick et al. [10] foram os primeiros a investigar o perfil da utilização do glicogênio em esforços acima da $\mathrm{iVO}_{2 \mathrm{PICO}}$ realizados de maneira intermitente $\left(6 x 1 \mathrm{~min}\right.$ a $150 \%$ da $\mathrm{iVO}_{2 \mathrm{PICO}}$, separados por $10 \mathrm{~min}$ de intervalo passivo). Estes autores observaram uma diminuição de $20 \%$ nas concentrações de glicogênio logo após o primeiro esforço e de $63 \%$ ao final do sexto esforço. Além disso, este estudo também demonstrou uma depleção do glicogênio significativamente superior nas fibras tipo II, indicando a importância deste substrato para a via glicolítica durante esforços intermitentes de alta intensidade.

Entretanto, em esforços realizados com B-Glic as concentrações de ácidos graxos livres (AGL) estão aumentadas desde o repouso, o que parece diminuir a taxa de utilização do glicogênio [55, 56]. Este "efeito protetor" dos AGL sobre a utilização do glicogênio induz uma maior utilização da via da $\beta$-oxidação, que possui uma potência inferior em relação à via glicolítica (i.e., menor energia por unidade de tempo) e, consequentemente, pode diminuir o desempenho em esforços intermitentes de alta intensidade. Embora esta explicação seja comumente aceita para explicar o menor desempenho em esforços com B-Glic, em esforços acima da $\mathrm{iVO}_{2 \mathrm{PICO}}$ as fibras do tipo II são recrutadas logo no início do exercício, aumentando a necessidade da utilização da glicólise $[10,11]$, o que pode atenuar este efeito poupador de glicogênio muscular. De fato, a manutenção do glicogênio em esforços intermitentes de alta 
intensidade com B-Glic ainda é pouco explorada na literatura [57].

Além destes fatores periféricos relacionados à fadiga em esforços intermitentes de alta intensidade, como mencionamos na introdução, em esforços com B-Glic pode ocorrer o aumento das quantidades de triptofano e outros metabólitos (e.g., IL-6), diminuindo a atividade dos motoneurônios via formação de serotonina [25, 27, 45-47]. Diferentemente das explicações relacionadas aos metabolismos energéticos (i.e., fadiga periférica), este panorama fisiológico caracteriza uma origem de fadiga central, o que ainda não foi investigado por estudos anteriores.

Desse modo, a fadiga em esforços intermitentes de alta intensidade com B-Glic pode apresentar tanto origem periférica como central. Para aumentar o conhecimento sobre estes fenômenos, o presente capítulo desta tese investigou especificamente, i) se o efeito poupador de glicogênio muscular ocorre em esforços intermitentes de alta intensidade e ii) se as quantidades de glicogênio muscular influenciam a origem da fadiga neste modelo de exercício.

\section{MATERIAIS E MÉTODO}

\section{Participantes}

Para investigar os efeitos do B-Glic sobre a fadiga em esforços intermitentes de alta intensidade, 11 indivíduos fisicamente ativos (26,8 \pm 2 anos, estatura de 173,5 $\pm 6,3 \mathrm{~cm}$ e peso corporal de 90,8 \pm 7,0 Kg) participaram voluntariamente. Previamente ao início das coletas, todos os indivíduos realizaram sessões de familiarização ao ergômetro de extensão dinâmica de joelhos, tanto de maneira dinâmica como para a execução da contração isométrica máxima, necessária para aplicação da técnica de twitch interpolation (TI).

\section{Delineamento experimental}

O delineamento experimental consistiu em cinco visitas ao laboratório. Na primeira 
visita, um teste incremental foi realizado para a determinação da $\mathrm{iVO}_{2 \mathrm{PICO}}$, utilizando o protocolo padronizado anteriormente. No dia anterior aos esforços intermitentes de alta intensidade (visitas 3 e 5), os participantes foram submetidos aos esforços para depleção do glicogênio (visitas 2 e 4). O intervalo entre a depleção e os esforços intermitentes de alta intensidade foi de $24 \mathrm{~h}$, onde os participantes receberam soluções contendo (100 g.L $\mathrm{L}^{-1}$ de maltodextrina) ou não contendo carboidratos. A administração das soluções cumpriu um delineamento duplo-cego, randomizado e contrabalanceado. O intervalo entre o primeiro esforço intermitente de alta intensidade e o próximo esforço para depleção do glicogênio foi de no mínimo $72 \mathrm{~h}$.

A força realizada a cada extensão foi monitorada para a determinação da potência e do trabalho, conforme descrito anteriormente no tópico sobre a construção e padronização do ergômetro utilizado. Os scores de glicogênio muscular foram estimados por meio de imagens de ultrassom, obtidas antes e após o esforço de depleção e durante os esforços intermitentes de alta intensidade. Durante todos os esforços intermitentes as variáveis ventilatórias foram monitoradas a cada ciclo de três respirações, seguindo as instruções de calibração e utilização do analisador de gases (VO2000; Medgraphics, Saint Paul, Minnesota, USA). A técnica de TI foi aplicada no repouso e após cada esforço intermitente de alta intensidade. Após a avaliação dos parâmetros relacionados a fadiga, amostras sanguíneas foram obtidas do lóbulo da orelha $(25 \mu \mathrm{L})$ para determinação das concentrações sanguíneas de lactato ([La-]) e de glicose ([Gli]) (YSI-2300; Yellow Springs Instruments ${ }^{\circledR}$, Ohio, USA). Por fim, a percepção subjetiva de esforço (PSE) também foi obtida ao final de cada esforço de alta intensidade por meio da escala de 10 pontos. A Figura 2 demonstra o delineamento experimental adotado nesta fase. 


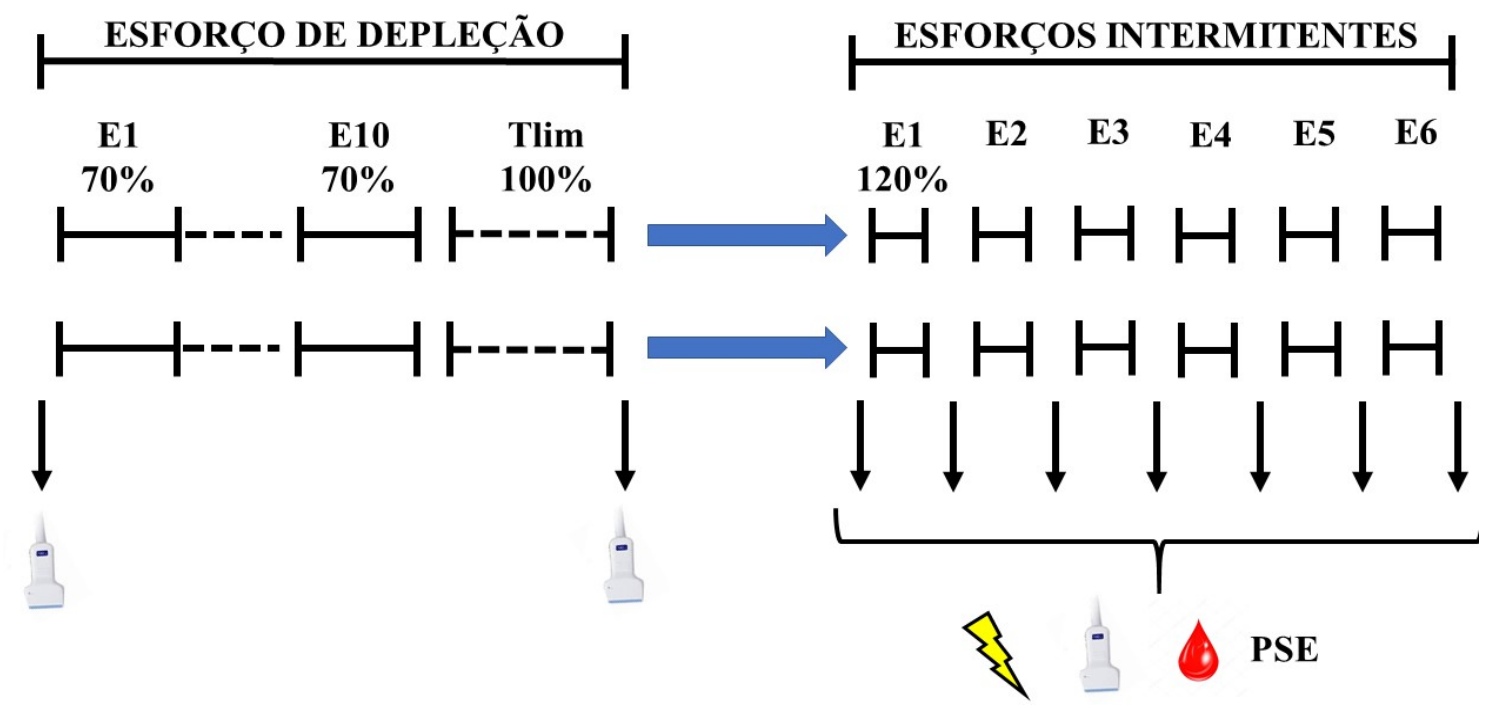

Figura 2. Delineamento experimental aplicado para avaliação da fadiga em esforços intermitentes de alta intensidade. Os percentuais representam a intensidade em relação a máxima atingida durante um teste incremental (iVO 2 PICO). Os esforços realizados a $70 \%$ da

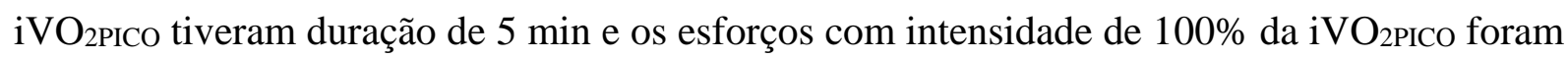
realizados até a exaustão voluntária (Tlim). Os esforços realizados a 120\% da iVO2PICo foram realizados por um minuto. fadiga; $\quad$ estimativa do conteúdo de glicogênio por meio de imagens de ultrassom; Coleta sanguínea para a determinação das concentrações de lactato e glicose; PSE: percepção subjetiva de esforço; $\Rightarrow$ : intervalo de recuperação (24h) com solução contendo maltodextrina ou placebo.

\section{Esforços de depleção}

O esforço de depleção consistiu em 10 esforços de cinco minutos com intensidade correspondente a $70 \%$ da iVO2PICO, seguidos de um esforço até a exaustão voluntária realizado a $100 \%$ da iVO2PICo (Tlim). Durante os esforços submáximos, pequenos ajustes na carga de exercício foram realizados nos casos em que o participante não foi capaz de manter a cadência 
por mais de 15 s (i.e., $60 \mathrm{rpm}$ ), apesar dos estímulos dos avaliadores. O intervalo entre os esforços submáximos foi de no máximo dois minutos. A exaustão durante o Tlim foi caracterizada pela incapacidade do avaliado em manter a cadência por mais de $15 \mathrm{~s}$ consecutivos.

\section{Esforços intermitentes de alta intensidade}

Seis esforços com duração um minuto e intensidade inicial correspondente a $120 \%$ da iVO 2 PICo foram realizados nesta fase. O intervalo entre estes esforços foi de $180 \mathrm{~s}$. Previamente a este exercício, os participantes realizaram um aquecimento de cinco minutos com intensidade correspondente a $50 \%$ da $\mathrm{iVO}_{2 \mathrm{PICO}}$. Durante os esforços de alta intensidade foram realizados ajustes na carga de exercício, sempre que o participante foi incapaz de manter a cadência (60 $\mathrm{rpm}$ ) por mais de $15 \mathrm{~s}$ consecutivos. Este procedimento foi adotado para que o volume total de esforços fosse cumprido. Nenhum feedback foi fornecido aos participantes em relação as cargas realizadas. Durante os intervalos entre os esforços de alta intensidade, as variáveis e técnicas foram aplicadas na seguinte ordem: TI, imagens de ultrassom, amostras sanguíneas e PSE. Caso tenha interesse, para melhor visualização da dinâmica de coletas a cada intervalo entre os esforços intermitentes de alta intensidade, disponibilizamos um vídeo ilustrativo no canal do nosso grupo de estudos.

\section{Administração das soluções e monitoramento da dieta}

As soluções foram administradas durante o período de recuperação conforme proposto por Alghannam et al. [6], induzindo uma situação onde o glicogênio apresenta uma recuperação (R-Glic) ou mantem-se em baixas quantidades musculares (B-Glic). Para isso, as soluções apresentavam sabor e odor similares entre as situações, sendo administradas de maneira 
isovolumétrica $(3,6 \pm 0,5 \mathrm{~L})$, gerando um consumo de carboidratos equivalente a $358 \pm 51,5 \mathrm{~g}$ durante todo o período de recuperação. Considerando a janela de oportunidade da primeira hora de recuperação [58], os participantes foram instruídos a ingerir $1000 \mathrm{~mL}$ de solução dentro deste período. As principais refeições durante o período de recuperação foram fornecidas pelos pesquisadores e as refeições intermediárias foram monitoradas por meio de recordatório alimentar (NutWin, versão 3.1, 2005). Os participantes foram instruídos a consumir alimentos com baixas quantidades de carboidrato, tanto na situação B-Glic como na situação R-Glic.

\section{Twitch Interpolation}

No repouso e imediatamente após o termino dos esforços de alta intensidade, a haste metálica foi fixada o mais rápido possível ( 10s) para a realização da contração isométrica máxima (CIM), que teve duração total de $5 \mathrm{~s}$. A força foi mensurada pelas células de carga acopladas na barra metálica conforme descrito no documento auxiliar. Para obtenção dos sinais

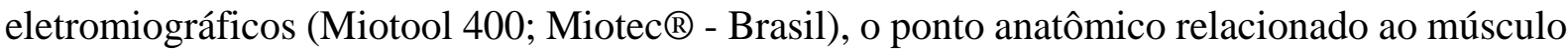
vasto lateral [59] foi tricotomizado e higienizado com álcool 70\%. Foram utilizados eletrodos de $\mathrm{Ag} / \mathrm{AgCl}$ com área de captação equivalente a $1 \mathrm{~cm}$ (3M®, São José do Rio Preto - Brasil) posicionados com uma distância de $3 \mathrm{~cm}$ de centro a centro. $\mathrm{O}$ sinal eletromiográfico foi adquirido em uma frequência de 2000 Hz, com ganho de 1000 vezes (Software Miograph; Miotec ${ }^{\circ}$, Brasil). Posteriormente, o sinal foi processado em um filtro passa-banda de 200-500 Hz.

A técnica de TI consistiu na mensuração da força gerada por meio de estimulação elétrica supramáxima, aplicada no nervo motor do músculo de interesse. Os eletrodos condutivos (5 por $5 \mathrm{~cm}$ ) foram posicionados no ponto de maior excitabilidade do triangulo femoral (catodo) e na dobra glútea (anodo). Os estímulos elétricos foram duplos (separados por $10 \mathrm{~ms}$ ) com duração 
de 1 ms (Bioestimulador, Insight $®$, Ribeirão Preto - Brasil). Este estimulador é um protótipo confeccionado pelo nosso grupo de pesquisa (para mais detalhes: $[49,60]$ ). A intensidade de estímulo elétrico foi relativa a $110 \%$ do limiar de estimulação (i.e., platô de força observado com o incremento de $10 \mathrm{~mA}$ ), determinado no músculo relaxado [61, 62]. Estes estímulos foram aplicados no terceiro segundo da CIM e após seu término com o músculo relaxado, entre o terceiro e sétimo segundo de recuperação. A variação no tempo de estimulação com o músculo relaxado foi importante para evitar a contração antecipada do avaliado. A CIM e as estimulações foram repetidas após $30 \mathrm{~s}$ de recuperação, sendo utilizada para as análises a contração com o sinal mais próximo do sinal de força típico da técnica de TI. O local de posicionamento dos eletrodos, tanto para a EMG como para a TI, foram mantidos até o final dos experimentos por meio de marcações na pele.

A força evocada no momento do estímulo durante a CIM foi assumida como Twitch Superimposed (TS). O pico de força induzido pelo estímulo elétrico aplicado no musculo relaxado (i.e., entre 3 e 7 s após a CIM), foi assumido como Twitch potenciada (TP). O percentual de ativação voluntária $(\% \mathrm{AV})$ foi determinado por meio da equação proposta por Allen et al. [63]. O perfil destas variáveis ao longo do comportamento de força está apresentado na Figura 3. A RMS foi calculada no segundo de esforço anterior a aplicação do estímulo elétrico. A máxima amplitude do sinal eletromiografico durante o estímulo elétrico foi considerada como amplitude da onda M. Embora sejam sempre interpretadas em contexto, diminuições nestas variáveis indicam um perfil de fadiga periférica (TP, Onda $M$ e razão RMS/Onda M) ou central (TS, \%AT e RMS) [6, 35, 61, 62]. 


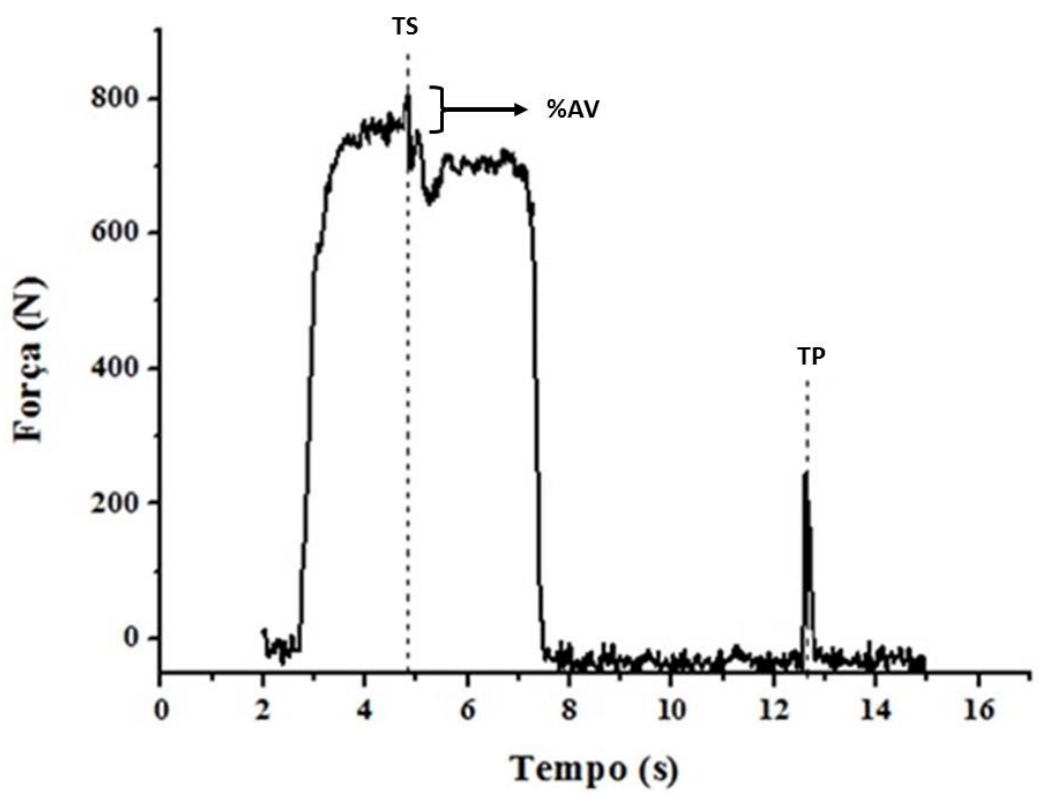

Figura 3. Comportamento da força durante a contração isométrica máxima (CIM) e sua recuperação. As linhas tracejadas indicam os momentos da estimulação elétrica. TS: força no momento do estímulo aplicado durante a CIM; \%AV: percentual de ativação voluntária; TP: Estimulo elétrico aplicado com o músculo relaxado, após a CIM.

\section{Estimativa do glicogênio muscular}

O local de aferição no reto femoral foi marcado previamente aos experimentos, sendo mantido até sua finalização. As medidas foram realizadas por meio de transdutor linear de 12 MHz conectado ao ultrassom de alta resolução GE LOGIQe (GE Healthcare, Milwaukee, WI, EUA). Todas as imagens foram realizadas em modo B, com dois focos (52\% de profundidade), ganho de $60 \mathrm{~dB}$, e profundidade equivalente a 3,5 cm. Estas especificações estão de acordo com as exigidas pelo software MuscleSound ${ }^{\circledR}$ (Denver, Colorado, USA), que permitiu a estimativa do conteúdo de glicogênio no músculo Rectus femoris $(41,51)$. A intensidade de brilho dos pixels foi mensurada em uma escala de 0 a 100, sendo que grandes quantidades de glicogênio muscular são indicadas por imagens hipoecogênicas (i.e., tendência para escala 0) e baixas 
quantidades hiperecogênicas (i.e., tendência para escala 100) (51). Como no mínimo três imagens são necessárias para este processo, durante as avaliações foram obtidas de 8 a 12 aquisições. Este procedimento é necessário pois imagens com baixa qualidade - com problemas na definição e/ou alinhamento do musculo ao centro da imagem - são automaticamente excluídas pelo software. No presente experimento, 292 imagens foram realizadas, sendo 205 efetivamente utilizadas para as análises. Estes procedimentos são os mesmos utilizados pelos estudos de validação desta técnica $(41,51)$.

\section{Análise estatística}

Os scores de glicogênio muscular e os parâmetros da TI, não apresentaram distribuição normal, quando determinados após a maioria dos esforços no domínio severo (Teste de ShapiroWilk: $\mathrm{p}<0,02)$. As tentativas de diminuir a assimetria das variáveis utilizando a logaritmização e os valores em raiz, não foram efetivas ( $\mathrm{p}<0,04)$. Desse modo, os dados estão apresentados em mediana (intervalo interquartil). As comparações entre os esforços e entre os grupos foi realizada por meio dos testes de Friedman e de Wilcoxon, respectivamente. Nos casos em que diferenças significativas foram observadas ao longo dos esforços, as comparações ponto a ponto também foram realizadas por meio do teste de Wilcoxon. Todas as análises foram realizadas pelo software SPSS 17.0 (SPSS Inc, Chicago, Illinois), com o nível de significância fixado em p-valor $<0,05$.

\section{RESULTADOS}

A iVO 2 PICo dos participantes foi de 94,5 (7,3) W. Durante os períodos de recuperação, os participantes ingeriram em média 2,6 (0,6) g de carboidrato, 75,8 $(13,4)$ g de proteínas e 26,2 $(4,8)$ g de lipídeos. Após o esforço de depleção, os escores de glicogênio muscular apresentaram 
valores significativamente inferiores em relação aos valores basais em ambas as situações ( $p$ valor < 0,03). Após $24 \mathrm{~h}$ de recuperação, a situação R-Glic apresentou scores de glicogênio significativamente superiores em relação a B-Glic ( $p$-valor < 0,04) (Figura 4). Na situação RGlic, os scores de glicogênio muscular diminuíram significativamente em relação ao repouso ( $p$-valor < 0,003), o que ocorreu a partir do quarto esforço. Entretanto, na situação B-Glic os scores não foram alterados em relação aos valores de repouso ( $p$-valor $>0,06)$. Além disso, os valores apresentados no sexto esforço foram significativamente inferiores na situação R-Glic $(p$-valor < 0,02) (Figura 5).

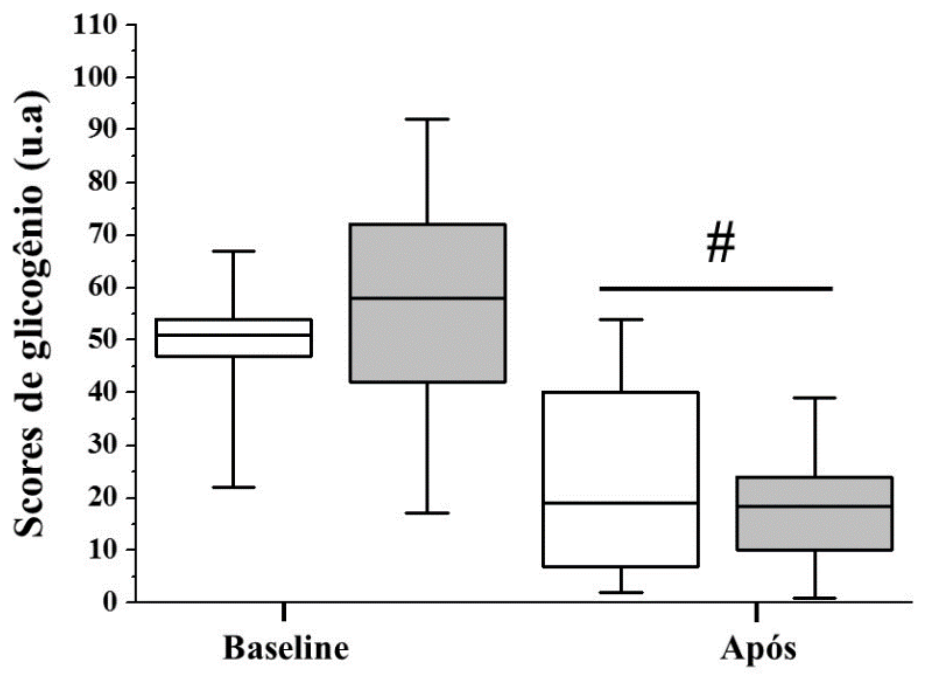

Figura 4. Comportamento dos scores de glicogênio antes e após o esforço de depleção. As caixas vazias representam a situação com baixa reposição de glicogênio (B-Glic) e as caixas cinzas representam a situação onde ocorreu a recuperação do glicogênio muscular (R-Glic). \#: Diferença significativa em relação ao repouso para ambas as situações. 


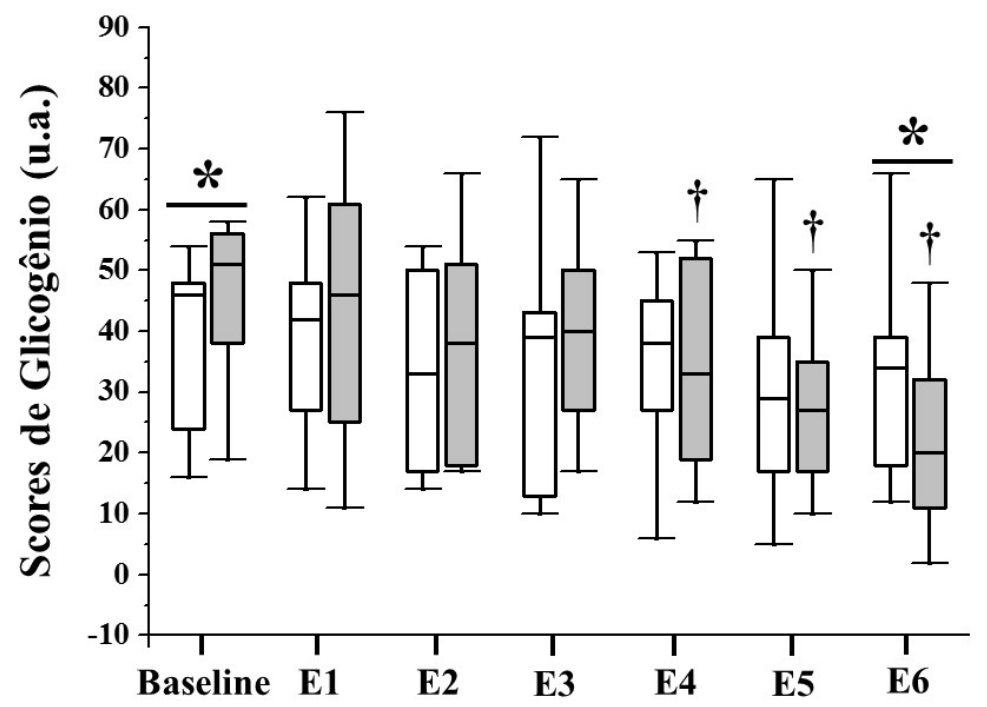

Figura 5. Comportamento dos scores de glicogênio ao longo dos esforços intermitentes de alta intensidade, realizados após $24 \mathrm{~h}$ de recuperação. As caixas vazias representam a situação com baixa reposição de glicogênio (B-Glic) e as caixas cinzas representam a situação onde ocorreu a recuperação do glicogênio muscular (R-Glic). *: Diferença significativa entre as duas situações; $\uparrow$ : Diferença significativa em relação ao repouso.

O desempenho observado nas duas situações ao longo dos esforços no domínio severo está apresentado na Figura 6. Na situação B-Glic a potência desenvolvida diminuiu significativamente a partir do quarto esforço $(p$-valor < 0,05). Na situação R-Glic, a potência diminuiu apenas no quarto esforço ( $p$-valor $>0,03$ ). O trabalho desenvolvido na situação BGlic diminuiu logo no segundo esforço ( $p$-valor > 0,02), o que ocorreu apenas após o quarto esforço na situação R-Glic ( $p$-valor $>0,02)$. 

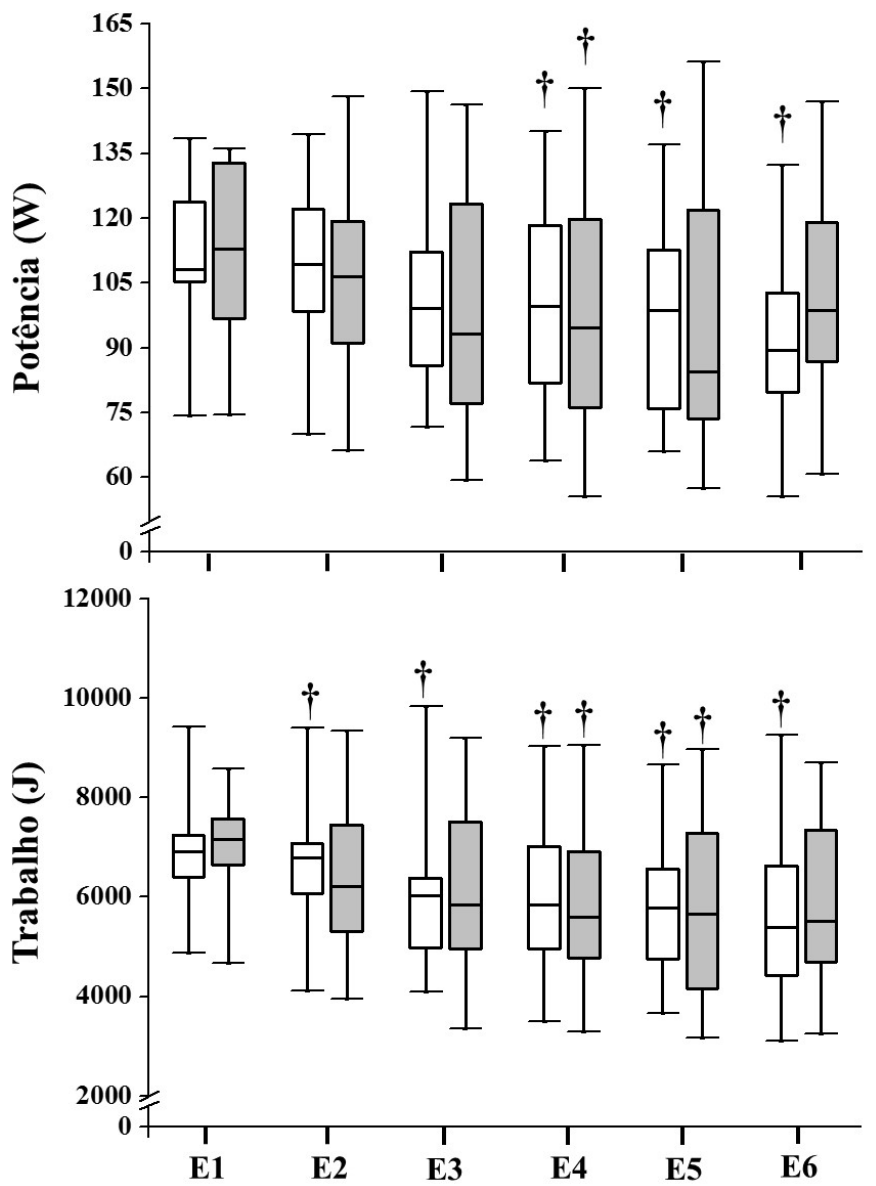

Figura 6. Valores de potência e trabalho observados ao longo dos esforços intermitentes de alta intensidade, nas situações onde ocorreu a reposição de glicogênio (R-Glic; caixas cinzas) e quando baixos scores foram observados (B-Glic; caixas vazias). †: Diferença significativa em relação ao primeiro esforço.

Os valores de PSE aumentaram significativamente ao longo dos esforços ( $p$-valor $<0,02)$, sem diferenças significativas entre as situações ( $p$-valor > 0,39) (Figura 7). Os comportamentos das variáveis ventilatórias ao longo dos esforços intermitentes de alta intensidade estão apresentados na Figura 8. A ventilação (VE), o $\mathrm{VO}_{2}$ e o $\mathrm{VCO}_{2}$, aumentaram significativamente em relação ao repouso, independentemente do esforço ( $p$-valor $<0,003)$. A VE no quarto esforço foi maior na situação B-Glic $(p$-valor $=0,04)$. Os valores de $\mathrm{VO}_{2}$ no segundo, quarto, quinto e sexto esforço, também foram superiores na situação B-Glic ((p-valor < 0,04). Nenhuma diferença significativa entre as situações foi observada para os valores de $\mathrm{VCO}_{2}(p$ valor > 0,20). Os valores em repouso do coeficiente respiratório (QR) foram significativamente inferiores na situação B-Glic ( $p$-valor = 0,02), o que ocorreu até o segundo esforço ( $p$-valor < 
0,05). Os valores de QR ficaram acima dos valores de repouso até o segundo esforço na situação R-Glic ( $p$-valor $<0,03)$ e até o quarto esforço na situação B-Glic $(p$-valor $=0,01)$.

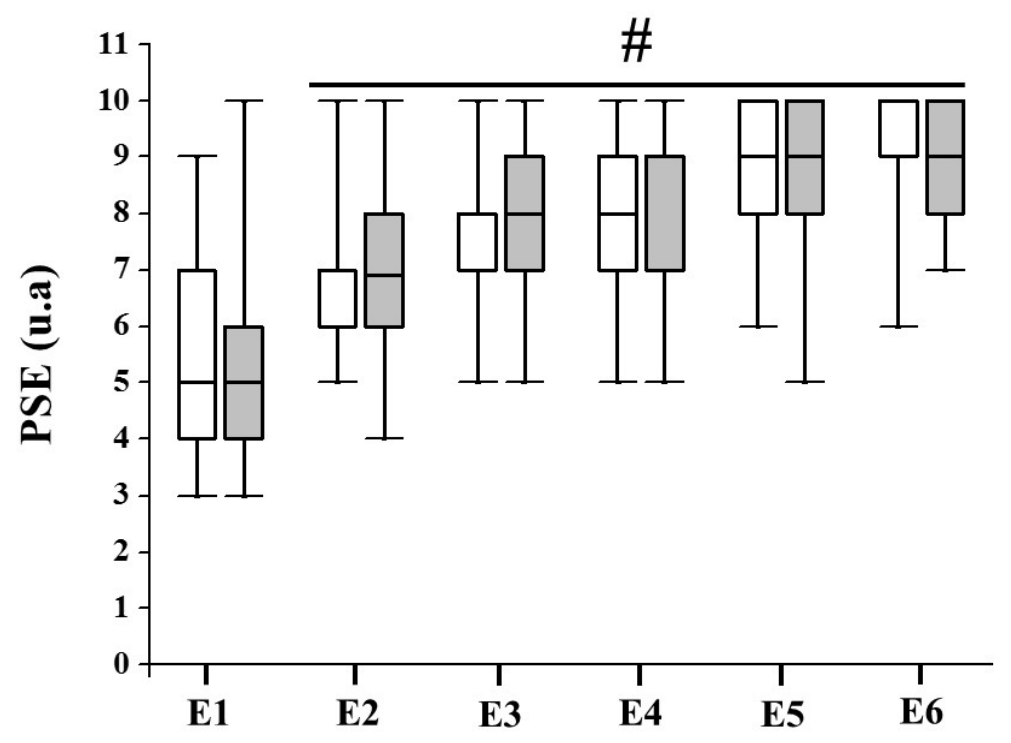

Figura 7. Valores de percepção subjetiva de esforço ao longo dos esforços intermitentes de alta intensidade. Os as caixas cinzas representam a situação onde o glicogênio muscular foi recuperado (R-Glic) e os símbolos vazios foram obtidos

na situação onde os scores apresentaram baixos valores (B-Glic). \#: Diferença significativa em relação ao primeiro esforço, para ambas as situações ( $p$-valor $<0,05)$. 

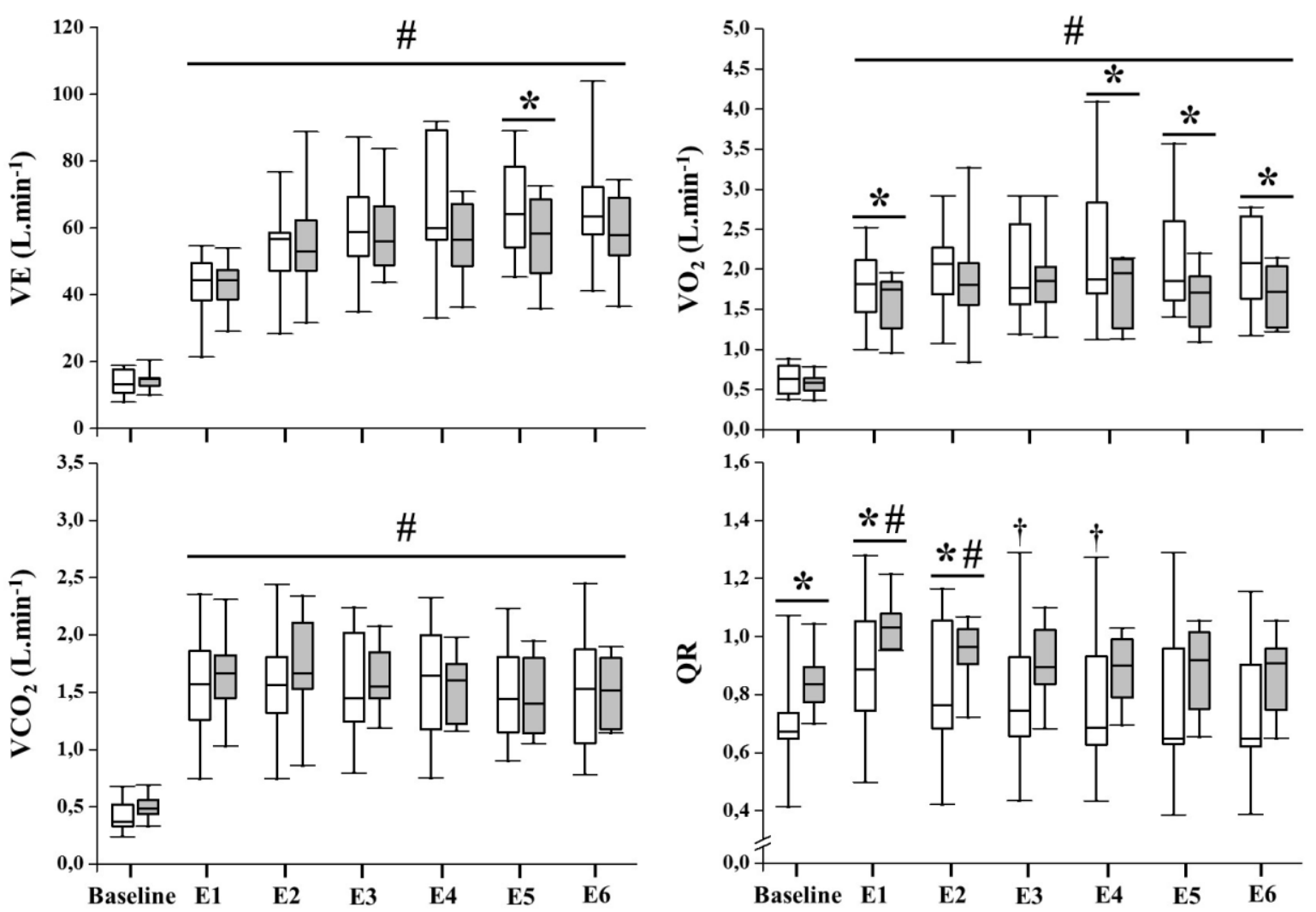

Figura 8. Comportamento das variáveis ventilatórias ao longo dos esforços intermitentes de alta intensidade. As caixas cinzas representam a situação onde o glicogênio muscular foi recuperado (R-Glic) e as caixas vazias representam a situação onde os scores apresentaram baixos valores (B-Glic). \#: Diferença significativa em relação ao primeiro esforço para as duas situações; $\dagger$ : Diferença significativa em relação ao primeiro esforço; *Diferença significativa entre as situações.

Os parâmetros obtidos por meio dos sinais de força com a aplicação da técnica de TI estão apresentados na Figura 9. A TS apresentou uma diminuição significativa desde o primeiro esforço $(p$-valor < 0,04), o que não foi diferente entre as situações $(p$-valor $>0,14)$. A TP também apresentou uma diminuição significativa desde o primeiro esforço ( $p$-valor $<0,02)$, sem diferenças significativas entre as situações ( $p$-valor $>0,39)$. A força pico (FP) apresentou uma diminuição significativa e progressiva ao longo dos esforços, para ambas as situações ( $p$ - 
valor < 0,012). Entretanto, nos três últimos esforços a FP foi significativamente superior na situação B-Glic ( $p$-valor < 0,03). A ativação voluntária (AV) não apresentou diferenças tanto entre os esforços $(p$-valor $>0,07)$ como entre as situações $(p$-valor $>0,11)$.
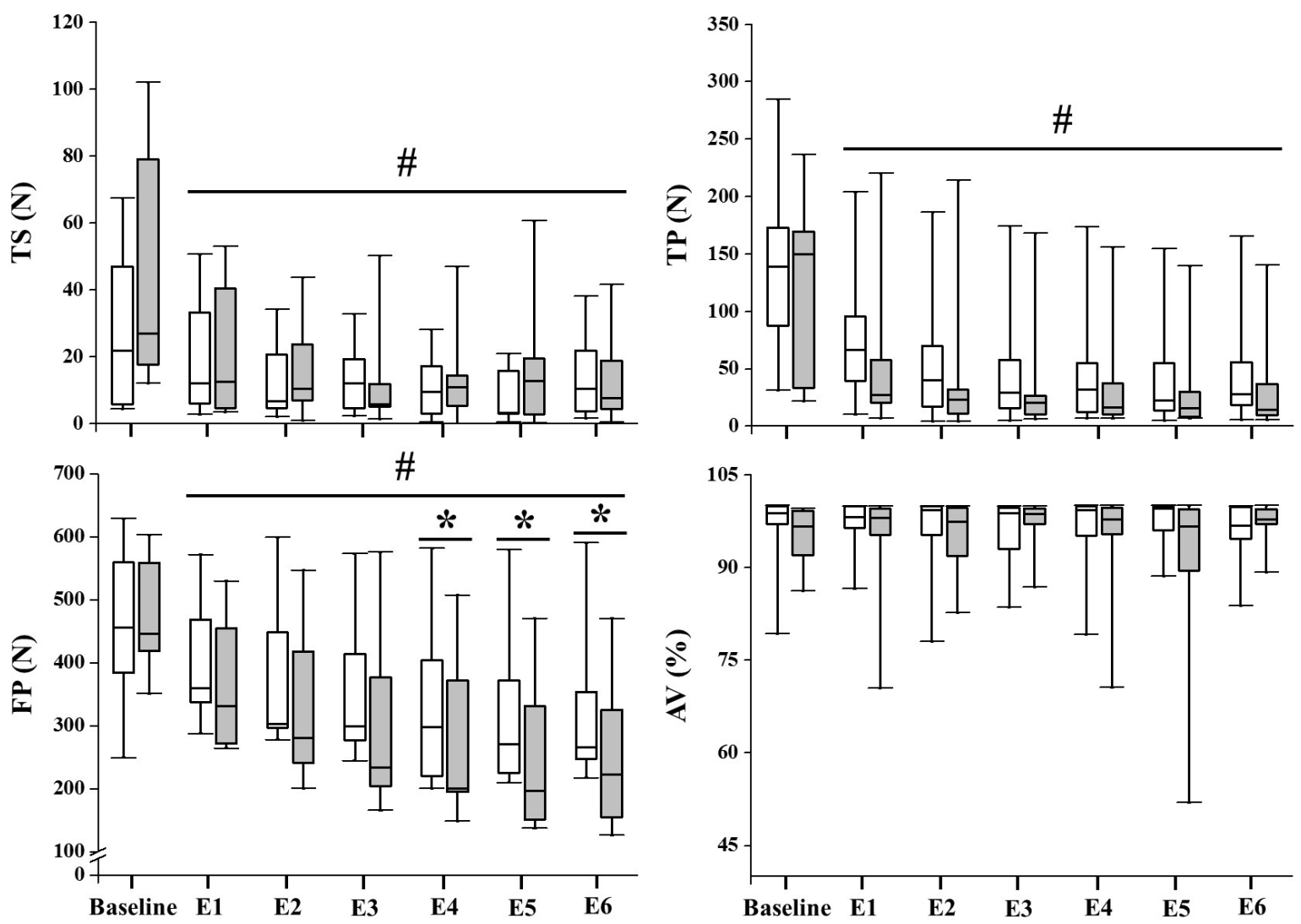

Figura 9. Comportamento das variáveis obtidas por meio dos sinais de força durante a técnica de Twitch Interpolation, ao longo dos esforços intermitentes de alta intensidade. As caixas cinzas representam a situação onde o glicogênio muscular foi recuperado (R-Glic) e as caixas vazias foram obtidas na situação onde os scores apresentaram baixos valores (B-Glic). TS: força evocada com o estímulo elétrico durante a contração isométrica máxima; TP: força evocada com o estímulo elétrico aplicado no músculo relaxado; FP: Força pico; AV: ativação voluntária obtida por meio desta técnica. \#: Diferença significativa em relação ao primeiro esforço para as duas situações; $\uparrow$ : Diferença significativa em relação ao primeiro esforço. 
Além dos dados obtidos por meio do sinal de força, a partir da técnica de TI também é possível extrair algumas variáveis oriundas da eletromiografia, as quais estão apresentadas na Figura 10. A root mean square (RMS) apresentou um aumento significativo em relação ao primeiro esforço $(p$-valor $<0,05)$, sem diferenças significativas entre as situações ( $p$-valor $>$ 0,38). A Onda M não foi alterada ao longo dos esforços, em ambas as situações ( $p$-valor > 0,28). Entretanto, a razão entre a RMS e Mwave, apresentou uma significativa elevação após o terceiro esforço em relação aos valores de repouso na situação B-Glic ( $p$-valor < 0,04), o que ocorreu somente após o quarto esforço na R-Glic ( $p$-valor $<0,02)$.

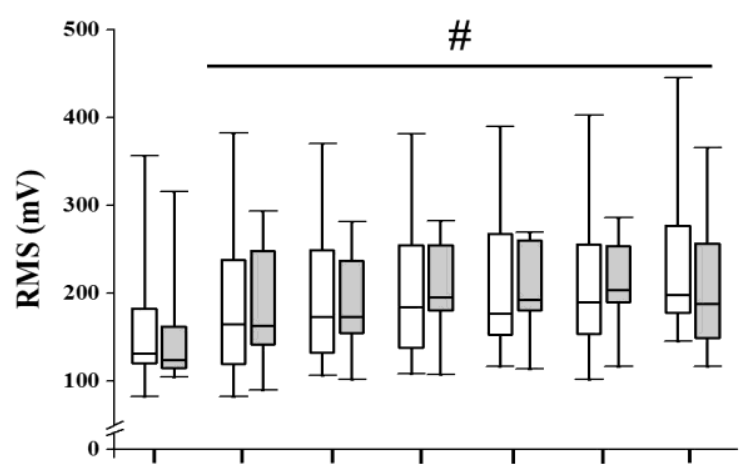

Figure 10. Comportamento das variáveis obtidas pelas análises eletromiográficas da técnica de Twitch Interpolation, aplicada ao longo dos intermitentes de alta intensidade. As caixas cheias representam a situação onde o glicogênio muscular foi recuperado (R-Glic) e

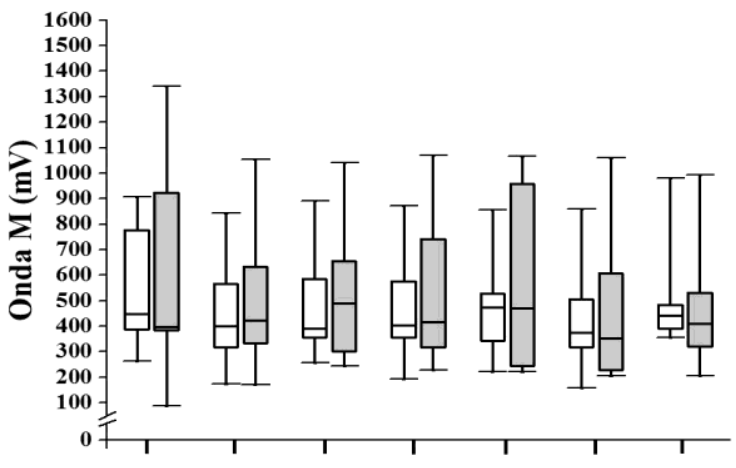
as caixas vazias foram obtidas na situação onde os scores apresentaram baixos valores (B-Glic). RMS: Root mean square; Onda M: Amplitude dos picos eletromiográficos logo

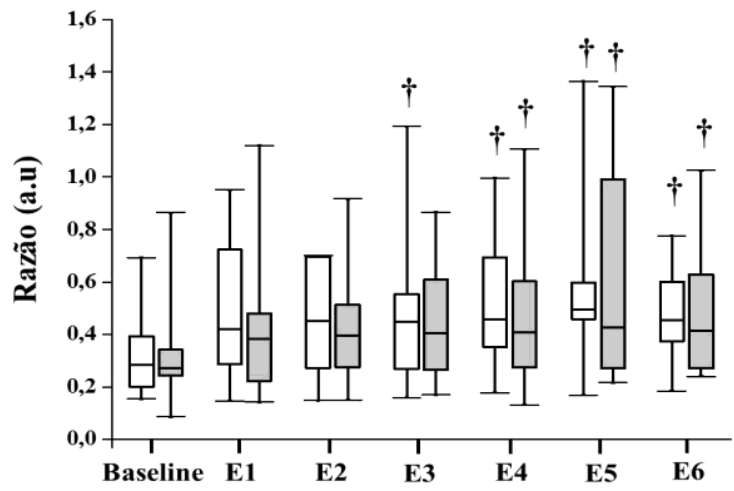
após o estímulo elétrico; Razão divisão da RMS pela Onda M. \#: Diferença significativa em relação ao primeiro esforço para as duas situações; $\dagger$ : Diferença significativa em relação ao primeiro esforço. 
As concentrações de glicose aumentaram em relação ao repouso no primeiro esforço na situação B-Glic $(p$-valor $=0,02)$ e diminuíram significativamente após o terceiro esforço na situação R-Glic ( $p$-valor $=0,01)$ (Figura 11). As concentrações de lactato aumentaram significativamente em relação ao repouso desde o primeiro esforço ( $p$-valor $<0,01)$, sem diferenças significativas entre as situações $(p$-valor $=0,12)($ Figura 11).
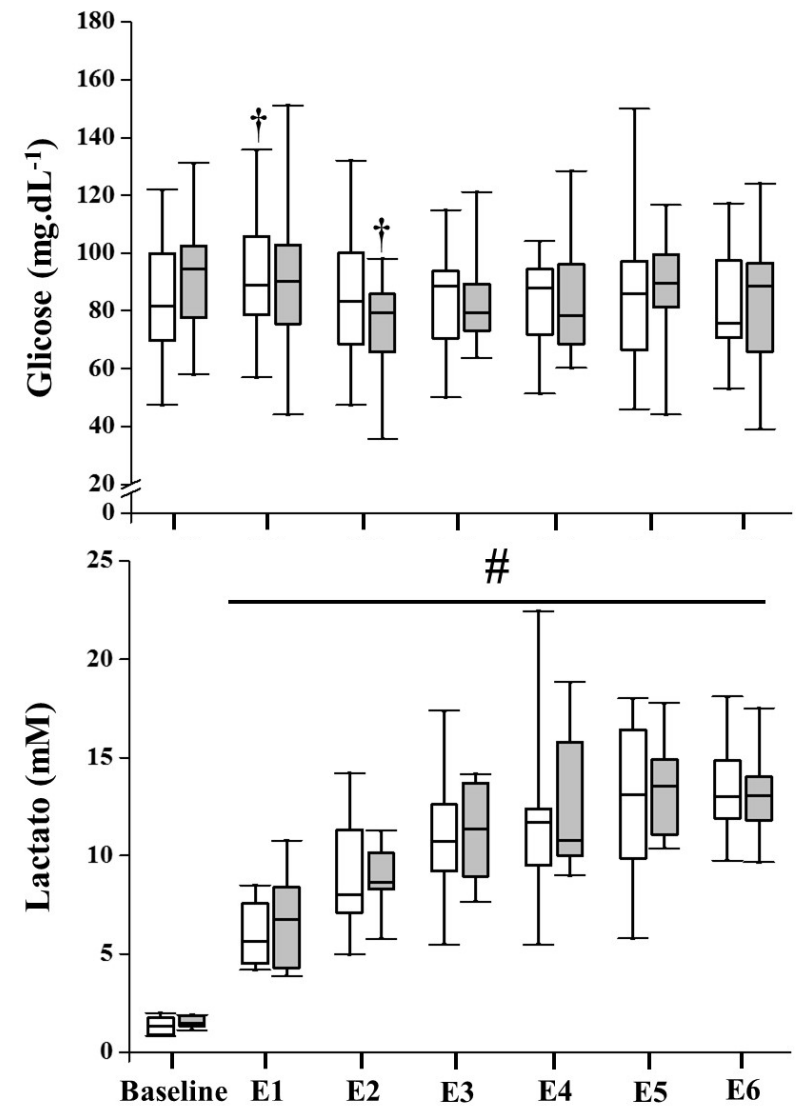

Figura 11. Comportamento das concentrações sanguíneas de glicose e lactato ao longo dos intermitentes de alta intensidade. As caixas cheias representam a situação onde o glicogênio muscular foi recuperado (R-Glic) e as caixas vazias foram obtidas na situação onde os scores apresentaram baixos valores (B-Glic). $\dagger$ : Diferença significativa em relação ao primeiro esforço.

\section{DISCUSSÕES E CONSIDERAÇÕES}

Os principais achados deste capítulo foram i) a confirmação de que o glicogênio é preservado na situação B-Glic, mesmo em esforços intermitentes de alta intensidade, e ii) a fadiga observada em esforços intermitentes de alta intensidade possui origens periféricas, sendo que na situação B-Glic o trabalho realizado diminui desde o segundo esforço realizado, o que ocorre apenas após o quarto esforço em R-Glic. 
Com um elegante delineamento experimental, Costill et al. [55], demonstraram que a utilização do glicogênio muscular é 40-50\% menor quando o exercício é realizado em elevadas concentrações sanguíneas de ácidos graxos livres (AGL). Os autores relacionaram estes achados ao aumento das concentrações de Acetil-CoA, oriundas da oxidação de lipídeos, que elevam as concentrações de citrato. Este panorama fisiológico leva a uma inibição da fosfofrutoquinase (PFK) com um consequente acumulo de Glicose-6-P, diminuindo drasticamente a eficiência da glicólise [56]. Além disso, ocorre um aumento da razão Glicose6-P/Frutose-1,6-BiP, o que inibe a enzima hexoquinase, diminuindo a oferta de substratos para a glicólise. Todo esse mecanismo favorece a utilização de lipídeos durante a atividade física, preservando o conteúdo de glicogênio durante exercício moderado [55].

Balsom et al. [57], utilizando um delineamento experimental similar ao presente estudo, observaram uma menor utilização do glicogênio muscular em uma situação de B-Glic, o que foi acompanhado por elevadas concentrações plasmáticas de AGL. Embora estes achados estejam de acordo com os mecanismos descritos acima, a diferença de utilização do glicogênio foi mais discreta $(\sim 10 \%$ a menos que o glicogênio utilizado na R-Glic) e o exercício foi acompanhado por elevadas concentrações sanguíneas de lactato (i.e., $10 \mathrm{mM}$ ), indicando que a glicólise não foi inibida na mesma magnitude do que durante o exercício moderado em RGlic, assim como apontam os resultados obtidos no presente estudo.

Embora seja esperado que as concentrações musculares de citrato estejam elevadas na situação B-Glic, durante a atividade intensa a razão ATP/ADP diminui drasticamente, anulando os efeitos inibitórios sobre a PFK e aumentando o fluxo da glicólise [64]. De fato, nossos resultados indicam que na situação B-Glic os lipídeos foram o principal substrato no repouso e durante os três primeiros esforços, o que foi indicado pelos valores de QR significativamente inferiores esta situação em relação a R-Glic. Após estes esforços os valores de QR foram 
similares aos observados na R-Glic, indicando uma troca de substratos utilizados durante o exercício. Estes resultados concordam com os apresentados por Hargreaves et al [56] que observaram uma preservação do glicogênio muscular, com uma concomitante ativação da glicólise durante o exercício. Assim, considerando a preservação dos scores de glicogênio na situação B-Glic, acompanhados por elevadas concentrações de lactato, é plausível supor que a glicose sanguínea tenha sido o principal substrato energético utilizado na situação B-Glic.

Além disso, os resultados do presente estudo demonstram que os fatores periféricos relacionados a fadiga ocorrem quase que concomitantemente ao declínio da potência e do trabalho durante os esforços intermitentes de alta intensidade. Mais especificamente, embora a diminuição da força pico possa estar relacionada a incapacidade/ineficiência do recrutamento motor pelo do sistema nervoso, durante nossos experimentos a força gerada involuntariamente (i.e., TS e TC) apresentou uma diminuição significativa ao longo do exercício, indicando a incapacidade muscular em gerar tensão, independentemente de fatores centrais [4]. Estes resultados são confirmados pelo aumento da RMS, indicando que a capacidade de recrutamento foi mantida ao longo dos esforços. Além disso, o aumento da razão RMS/Onda M demonstra que a capacidade de recrutamento muscular foi mantida sem grandes alterações na resposta do sarcolema. Outro resultado observado com este estudo foram os valores inferiores de força pico observados na situação R-Glic, o que pode ter sido ocasionado pelo maior distúrbio metabólico nesta situação (i.e., maiores concentrações de $\mathrm{H}^{+}$, ADP e Pi) e consequentemente, a uma diminuição do pH, fatores relacionados a diminuição da força em CIM [65]. Nossos resultados também demonstram que as possíveis alterações sistêmicas induzidas pela situação B-Glic (e.g., aumento do TrP, catecolaminas e AGL), não foram suficientes para induzir um quadro de fadiga central. Em outras palavras, durante o exercício aplicado pelo presente estudo, o modelo de "governador central" não foi evidenciado. 
O principal aspecto inovador do presente estudo foi a utilização das imagens de ultrassom para a estimativa do glicogênio muscular, o que possibilitou o monitoramento desta variável em diferentes momentos do delineamento. Esta técnica foi validada recentemente por meio de comparações utilizando medidas diretas do glicogênio muscular [52, 53], sendo considerada promissora para estudos em fisiologia do exercício [66]. Além disso, embora uma limitação na utilização desta técnica poderia ser a experiência do avaliador em manusear o transdutor, nos preocupamos em padronizar o local das aferições e o software reconhece as melhores imagens, levando em consideração a centralização do músculo de interesse e a nitidez das imagens. Assim, considerando os resultados de estudos clássicos sobre a depleção do glicogênio durante o esforço severo [10] e as padronizações adotadas, os resultados do presente estudo confirmam que os scores obtidos por ultrassom apresentaram um comportamento muito parecido com os observados por meio da biópsia muscular, representando uma metodologia não invasiva para o controle deste substrato energético.

Além da utilização do ultrassom para a estimativa do glicogênio muscular, outro aspecto metodológico do presente estudo que merece destaque é a utilização da estratégia duplo-cego e randomizada. Noakes [29] após uma elegante revisão, observou que a maioria dos estudos realizados sobre os efeitos do conteúdo de glicogênio sobre o desempenho, não garantiram a situação placebo durante o delineamento experimental. Os resultados do presente estudo demonstram que obtivemos sucesso em induzir scores de glicogênio superiores na situação RGlic em relação a B-Glic, o que representa o primeiro estudo sobre a origem da fadiga que utilizou a estratégia duplo-cego. Entretanto, as diferenças não foram elevadas, o que pode ter gerado algum fator de confusão em nossas análises. Em outras palavras, embora as diferenças estatísticas tenham sido significativas entre as situações, certa recuperação também ocorreu na situação B-Glic, o que pode ter comprometido as possíveis diferenças no desempenho e no 
perfil da fadiga observado durante o domínio severo. Acreditamos que o aumento dos scores de glicogênio na situação de B-Glic tenha sido induzido pela gliconeogênese durante o período de recuperação [67]. Além disso, a suposição de que as concentrações de AGL foram superiores na situação B-Glic não foram provadas, assim estas pequenas diferenças no glicogênio entre as situações, embora significativas, podem ter sido insuficientes para induzir estas respostas sistêmicas.

Considerando estas possíveis limitações, concluímos com o presente estudo que ocorrem diferenças importantes na utilização do glicogênio muscular em situações com B-Glic, onde este substrato é preservado, mesmo em esforços de alta intensidade que induzem elevadas concentrações de lactato. Este resultado, aliado ao fato de a força pico ter diminuído mais abruptamente na situação R-Glic, parece uma vantagem na utilização de esforços com B-Glic. Entretanto, o menor desempenho observado pode representar uma importante limitação da utilização de esforços com B-Glic no meio esportivo. Outro resultado importante do presente estudo demonstrou que, embora a situação B-Glic tenha apresentado scores de glicogênio inferiores, esta situação metabólica não influenciou significativamente a origem e o perfil da fadiga durante esforços intermitentes de alta intensidade, a qual possui caráter periférico. Neste sentido, é possível que a continuidade do exercício possa induzir diferenças mais significativas entre as situações B-Glic e R-Glic.

Estudos futuros devem preocupar-se em induzir diferenças mais abruptas sobre o glicogênio de repouso e aumentar a quantidade de esforços, possibilitando uma investigação mais profunda dos mecanismos energéticos durante o exercício de alta intensidade em situação de B-Glic. Nestes estudos a Além disso, embora pautadas em vários estudos prévios e com evidências sistêmicas (e.g., alterações no QR e elevadas concentrações de lactato), as inferências moleculares discutidas aqui não foram observadas durante esforços intermitentes de 
alta intensidade, demonstrando uma importante lacuna na literatura que deve ser explorada futuramente.

\section{Capítulo 4 - Origem da fadiga em eSforços De DURAÇÃO MODERADA REALIZADOS COM DIFERENTES CONTEÚDOS DE GLICOGÊNIO MUSCULAR}

\section{BACKGROUND}

Este capítulo descreve a realização do último experimento proposto para responder à pergunta central da presente tese. Embora os scores de glicogênio tenham sido modulados entre as situações, tivemos uma preocupação com a magnitude das diferenças observadas. Com isso, nossa primeira alteração experimental seria a utilização de mais esforços de depleção, acompanhados por uma dieta com baixas quantidades de carboidratos, e seguidos por um período de supercompensação do glicogênio (i.e., diminuição da carga de exercício e aumento da oferta de carboidratos).

Entretanto, nosso cronograma culminou na indisponibilidade do equipamento de ultrassom utilizado nos primeiros experimentos. Desse modo, para os experimentos demonstrados neste capítulo, optamos por determinar as concentrações de glicogênio muscular por meio da técnica de biópsia muscular. Por ser considerada como o método "padrão ouro" para a determinação do glicogênio muscular e possibilitar outras análises que não foram previstas, acreditamos que a utilização da biópsia muscular representou um avanço metodológico para a presente teste. Entretanto, este é um procedimento que necessita de vários detalhes metodológicos os quais estão descritos no documento auxiliar (Documento auxiliar V - Padronização da biópsia e determinação do glicogênio). 
Após a revisão da literatura, observamos que a influência do o glicogênio muscular em esforços maiores que 90min está bem estabelecida. Entretanto, esforços de moderada duração (i.e., 20 - 90 min) ainda possuem resultados inconclusivos. Além disso, o estudo de Alghannam et al. [68] demonstra um aspecto importante pouco explorado na literatura, sendo: qual é a influência da disponibilidade de glicogênio sobre o desempenho até a exaustão realizado após esforços de moderada duração? Este conhecimento pode ser de grande valia para modalidades onde o final de provas relativamente longas deve ser realizado em alta intensidade (e.g., ciclistas sprinters). Os delineamentos observados raramente induziram comparações entre B-Glic e RGlic associando dietas e exercício para a depleção e posterior supercompensação, representando uma linha de pensamento metodológico ainda não utilizado em estudos sobre este tema. Finalmente, a origem da fadiga em esforços com moderada duração seguidos de um esforço até a exaustão, semelhantemente ainda não foi investigada na literatura.

Considerando estas lacunas, os procedimentos descritos neste capítulo avançam para responder à pergunta central desta tese, especialmente sobre a origem da fadiga em esforços de longa duração. Para isso, além da técnica de Twitch Interpolation (TI), utilizamos neste experimento a técnica de estimulação magnética transcraniana (EMT) que possibilita a avaliação da fadiga supra espinhal, uma ramificação importante da fadiga de origem central [45-47]. Além disso, amostras sanguíneas foram retiradas para a determinação das concentrações plasmáticas de triptofano, um dos principais agentes causadores da fadiga supre espinhal (i.e., hipótese serotoninérgica) [25, 27]. Desse modo, o delineamento proposto neste capítulo i) aumenta a diferença entre os valores de glicogênio em repouso, determinados por biópsia muscular, ii) descreve a origem da fadiga periférica e central (infra e supra espinhal) e iii) testa a hipótese de que as concentrações de triptofano são relacionadas a fadiga central em exercícios prolongados. 


\section{MATERIAIS E MÉTODO}

\section{Participantes}

Completaram o delineamento deste estudo oito participantes fisicamente ativos (idade de $26 \pm 3$ anos, estatura de $175,6 \pm 6,3 \mathrm{~cm}$ e peso corporal de 87,3 $\pm 18,9 \mathrm{Kg}$ ). Todos os participantes eram familiarizados com a extensão dinâmica de joelhos, modelo de exercício adotado em todo o delineamento deste estudo.

\section{Delineamento experimental}

O delineamento teve duração de 12 dias consecutivos, compostos por dez visitas ao laboratório. Na primeira visita, os participantes realizaram um teste incremental, seguido de 20 min de um esforço a $70 \%$ da $\mathrm{iVO}_{2 \mathrm{PICO}}$, que teve objetivo de iniciar a depleção do glicogênio muscular. Na segunda, terceira e quarta visitas, foram realizados esforços específicos para a depleção do glicogênio muscular. A primeira biópsia muscular foi realizada na quinta visita. $\mathrm{Na}$ sexta e sétima visita foram realizados dois esforços a $80 \%$ da $\mathrm{iVO}_{2 \mathrm{PICO}}$ com duração de 15

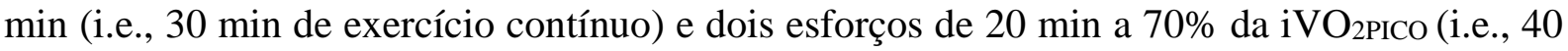
min de exercício contínuo), respectivamente. Estes esforços foram seguidos de um esforço até a exaustão (Tlim) realizado a $80 \%$ da $\mathrm{iVO}_{2 \text { PICO }}$ (E30Tlim e E40Tlim, respectivamente), caracterizando os exercícios realizados com B-Glic. Após três dias com uma dieta com elevadas quantidades de carboidrato, os participantes realizaram uma nova biópsia (oitava visita) e os esforços de interesse foram repetidos (nona e décima visitas, exercícios em R-Glic). A Figura 12 ilustra este novo delineamento. O teste incremental, o recordatório alimentar e a técnica de TI foram aplicados conforme descrito no capítulo anterior. 


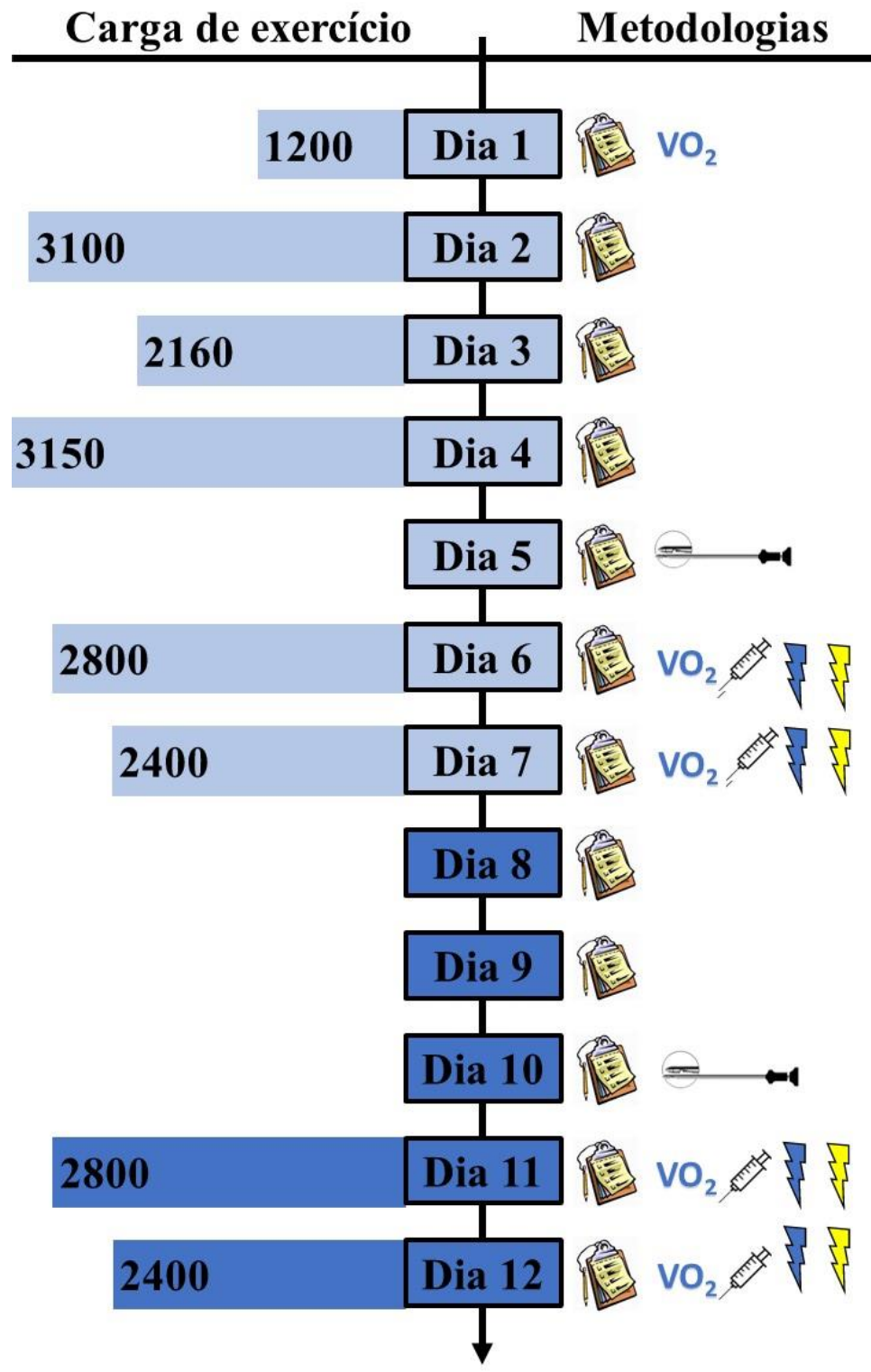

Figura 12. Delineamento experimental do presente estudo. Durante o experimento, as dietas com baixas quantidades de carboidrato (azul claro) e de alta quantidade de carboidratos (azul escuro) foram fornecidas pelos pesquisadores. Os valores de carga externa (i.e., produto entre o volume total e a intensidade em percentual da $\mathrm{iVO}_{2 \mathrm{PICO}}$ ) estão apresentados em unidades arbitrárias. recordatório alimentar; $\mathrm{VO}_{2}$ : monitoramento das variáveis ventilatórias; $=-m$ : extração de tecido por meio da técnica de biópsia muscular; ฟ:

aplicação da técnica de Twitch Interpolation; : aplicação da técnica de estimulação magnética transcraniana.

\section{Sessões para depleção do glicogênio muscular}

Nas quatro primeiras sessões, foram aplicados diferentes esforços para a depleção do glicogênio muscular (A, B, C e D). A sessão "A" foi constituída pelo teste incremental e dois esforços de 10 min com intensidade correspondente a $70 \%$ da $\mathrm{iVO}_{2 \mathrm{PICO}}$, separados por dois 
minutos de recuperação passiva (Volume total de $\approx 40 \mathrm{~min}$ ). A sessão "B" foi composta por doze esforços de 5 min com intensidades correspondentes a 50 (2 esforços), 60 (seis esforços), 70 (2 esforços) e $80 \%$ ( 2 esforços) da iVO 2 PICo. A sessão “C” foi composta por um aquecimento e por uma sessão principal em alta intensidade. $\mathrm{O}$ aquecimento foi realizado por meio de um esforço contínuo de 10 min com intensidades oscilando em 50, 60, 50, 70 e $50 \%$ da iVO 2 PICO (i.e., 2 min em cada intensidade). Durante a sessão principal foram realizados 20 esforços de um minuto com intensidade correspondente a $80 \%$ da $\mathrm{iVO}_{2 \mathrm{PICO}}$, sendo aplicados em uma relação esforço pausa de 1:1. A sessão “D” foi semelhante ao esforço de depleção utilizado nos experimentos anteriores, sendo constituída por uma fase progressiva, onde um esforço de 15 min foi realizado nas intensidades de 30,50 e $60 \%$ da iVOPIco ( 5 min em cada intensidade), seguida de sete esforços de 5 min realizados a $70 \%$ da iVO 2 PICO. Em todas as sessões ajustes na intensidade foram realizados para que o volume total fosse cumprido. O intervalo máximo entre cada esforço em todas as sessões foi de três minutos.

\section{Biópsias musculares e determinação do glicogênio}

Para os procedimentos de biópsia muscular, as amostras foram extraídas das duas pernas, de maneira randomizada e contrabalanceada entre as duas visitas. Todos os procedimentos foram realizados por uma médica com treinamento específico em extração de tecido muscular. A região de interesse (porção medial do músculo vasto lateral) foi tricotomizada e limpa com liquido antisséptico. Na sequência, a região foi anestesiada com xilocaína (2\%), permitindo a realização de uma incisão de aproximadamente $5 \mathrm{~mm}$ até a fáscia do músculo. O tecido muscular foi extraído por meio de uma agulha específica para biópsia muscular, a qual foi inserida a uma profundidade de aproximadamente 2,5 a $3 \mathrm{~cm}$. Em média foram extraídos 0,111 $\pm 0,04 \mathrm{~g}$ e $0,101 \pm 0,02 \mathrm{~g}$ na primeira e na segunda visitas, respectivamente. As amostras de 
tecido foram imediatamente congeladas por meio de nitrogênio líquido e posteriormente armazenados $-80^{\circ} \mathrm{C}$.

As concentrações de glicogênio foram determinadas por método colorimétrico, conforme proposto por Dubois et al. (1). A absorbância foi medida em espectrofotômetro 490nm. Sete padrões foram confeccionados por meio de soluções conhecidas de glicose entre 10 e 90 g.mL $\mathrm{mL}^{-1}$. A curva de calibração apresentou elevados índices de linearidade $\left(\mathrm{r}^{2}=0,998\right)$. Para as concentrações observadas na situação B-Glic, utilizamos para a análise de absorbância $300 \mu \mathrm{L}$ de amostra. Entretanto, na situação em que os estoques de glicogênio foram supercompensados, considerando a elevada concentração de glicogênio nesta situação, apenas $20 \mu \mathrm{L}$. Estas diferenças foram padronizadas anteriormente e corrigidas conforme proposto pela equação da metodologia original (1). (Documento auxiliar V - Padronização da biópsia e determinação do glicogênio).

\section{Exercícios de interesse}

O E30Tlim foi composto de dois esforços de 15 min com intensidade inicial de $80 \%$ da iVO 2 PICO, seguido de um esforço até a exaustão na intensidade correspondente a $80 \%$ da iVO 2 PICO. Diferentemente, o exercício E40Tlim teve intensidade inicial de $70 \%$ da iVOPICO, sendo composto por dois esforços de 20 min, seguido de um esforço até exaustão na intensidade correspondente a $80 \%$ da iVO2PICO. Ajustes na intensidade de exercício foram realizados sempre que o participante foi incapaz de manter a cadência de $60 \mathrm{rpm}$ por mais de $10 \mathrm{~s}$ consecutivos. Durante estes esforços, o participante foi orientado a realizar o máximo de trabalho possível, logo a intensidade poderia ser aumentada novamente ao longo do exercício, por solicitação do participante. O intervalo entre os dois esforços em ambos os domínios foi o mínimo para que todas as coletas fossem realizadas (i.e., TI, EMT e amostras sanguíneas). 


\section{Estimulação magnética transcraniana (EMT)}

A técnica de EMT utiliza esforços isométricos submáximos [45-47, 69, 70], que foram aplicados antes das CIM utilizadas para a TI. O estímulo magnético foi aplicado por uma bobina figura oito com $110 \mathrm{~mm}$ de diâmetro e potência máxima de saída equivalente a 1,4 T [45, 70]. Previamente aos esforços isométricos, o ponto de estimulação craniana foi determinado com auxílio da neuronavegação, previamente validado [71]. A intensidade inicial do estimulo foi ajustada em $60 \%$, referente a potência máxima de saída, sendo aumentada em 5\%. O limiar de estimulação foi determinado durante uma contração isométrica a 20\% da CIM, sendo assumido como a intensidade de estimulação magnética associada a maior força evocada no quadríceps. O estímulo durante as avaliações correspondeu a $120 \%$ do limiar de estimulação. A excitabilidade cortical (EC) foi avaliada por meio das respostas médias de cinco estímulos durante uma contração isométrica a $20 \%$ da CIM. Além da força evocada, foram determinadas as variáveis de amplitude do estímulo (Amp), do tempo entre os picos positivo e negativo (Tpp) e do tempo de silencio (i.e., tempo após o estímulo para que o sinal de EMG volte a ter o comportamento característico de uma contração isométrica; Tsil). A diminuição destes fatores após o exercício, indica um perfil de fadiga central relacionada ao nível cortical [45-47, 69, 70, 72]. Mais informações sobre o sinal típico, a determinação dos parâmetros obtidos pela EMT e os problemas metodológicos observados com sua aplicação, estão disponíveis no documento auxiliar (Documento auxiliar VI - A técnica de estimulação magnética transcraniana).

\section{Determinação das concentrações de triptofano $(\mathrm{Tr} P)$}

Foram coletados $4 \mathrm{ml}$ de sangue da veia basílica mediana direita por meio de sistema a vácuo com anticoagulante EDTA (Venipuncture Needle-Pro, Portex, Keene, NH). As amostras 
foram obtidas no repouso e após os dois esforços constantes. Posteriormente as amostras foram centrifugadas por 15 minutos a $300 \mathrm{x}$ g, para separação do plasma, que foi armazenado em freezer $-80^{\circ} \mathrm{C}$ para posterior análise. Embora todos os procedimentos para a determinação do TrP utilizando o método HPLC tenham sido descritos por Sultana et al. [73], fatores como o modelo do equipamento e da coluna, a marca e pureza dos reagentes e padrões utilizados, podem influenciar no cromatograma observado. Desse modo, uma série de tentativas foram realizadas para ajustar a técnica ao equipamento utilizado no presente estudo, os quais estão descritos no documento auxiliar (Documento auxiliar VII - Determinação do triptofano). Todos os procedimentos foram antecedidos pela calibração do equipamento e do sistema por meio de sete pontos com concentrações de $\operatorname{TrP}$ variando entre 0,25 e $20 \mu \mathrm{g} \cdot \mathrm{mL}^{-1}$. Todas as retas de calibração apresentaram elevados índices de linearidade $\left(\mathrm{r}^{2}>0,998\right)$.

\section{Análises estatísticas}

Neste experimento, alguns valores observados no desempenho e com a técnica de TI, não apresentaram uma distribuição normal. As tentativas de diminuir a assimetria das variáveis utilizando a logaritmização e os valores em raiz, não foram efetivas $(\mathrm{p}<0,04)$. Além disso, a efetividade da EMT não foi elevada, principalmente no E30Tlim na situação R-Glic (i.e., comportamentos atípicos do sinal eletromiográfico). Desse modo, as comparações entre as situações B-Glic e R-Glic para os dados de EMT foram realizadas com cinco participantes e somente no E40Tlim. Os dados estão apresentados em mediana (intervalo interquartil). As comparações entre os esforços e entre os grupos foi realizada por meio dos testes de Friedman e de Wilcoxon, respectivamente. Nos casos em que diferenças significativas foram observadas ao longo dos esforços, as comparações ponto a ponto também foram realizadas por meio do teste de Wilcoxon. As possíveis correlações entre os parâmetros de fadiga e as concentrações 
de TrP foram realizadas pelo teste de Spearman. Para testar as possíveis relações, além dos valores absolutos de $\operatorname{TrP}\left(\mu \mathrm{g} \cdot \mathrm{mL}^{-1}\right)$, também foram utilizadas as diferenças percentuais observadas ao longo dos esforços $\left(\Delta=\left[\right.\right.$ Segundo esforço $\cdot 100 \cdot$ Repouso $\left.\left.^{-1}\right]-100\right)$. Todas as análises foram realizadas pelo software SPSS 17.0 (SPSS Inc, Chicago, Illinois), com o nível de significância fixado em $p$-valor $<0,05$.

\section{RESULTADOS}

\section{Efetividade do delineamento}

A Figura 13 demonstra o consumo de macronutrientes nas situações experimentais BGlic e R-Glic. A quantidade de carboidratos foi significativamente superior ( $p$-valor $=0,012$ ) para induzir a situação R-Glic. As quantidades de lipídeos não foram diferentes entre as situações $(p$-valor $=0,40)$. No período de supercompensação os participantes ingeriram significativamente menos proteínas $(p$-valor $=0,012)$. Com isso, nosso delineamento experimental induziu concentrações de glicogênio significativamente inferiores após os esforços de depleção em relação aos valores observados após o período de supercompensação $(\mathrm{p}=0,0001)$. De fato, as concentrações de glicogênio aumentaram para todos os participantes (Figura 14). 


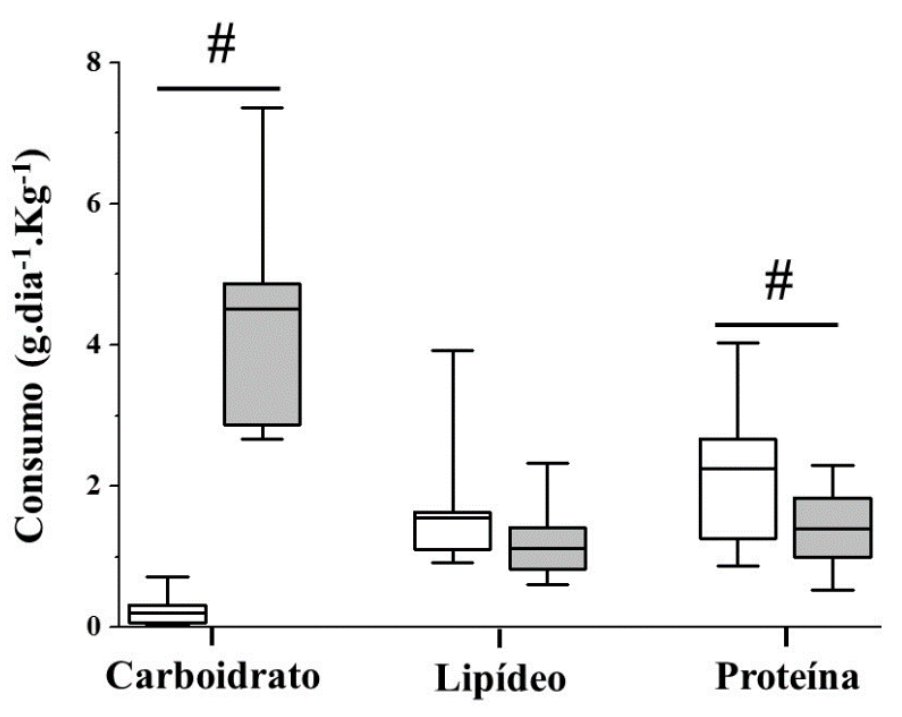

Figura 13. Quantidades ingeridas dos macronutrientes para induzir a depleção (i.e., caixas vazias) ou o fenômeno de supercompensação do glicogênio muscular (i.e., caixas cinzas). As caixas vazias representam a situação B-Glic e as cinzas os valores observados em R-

Glic. \#: Diferença significativa entre as duas situações experimentais.

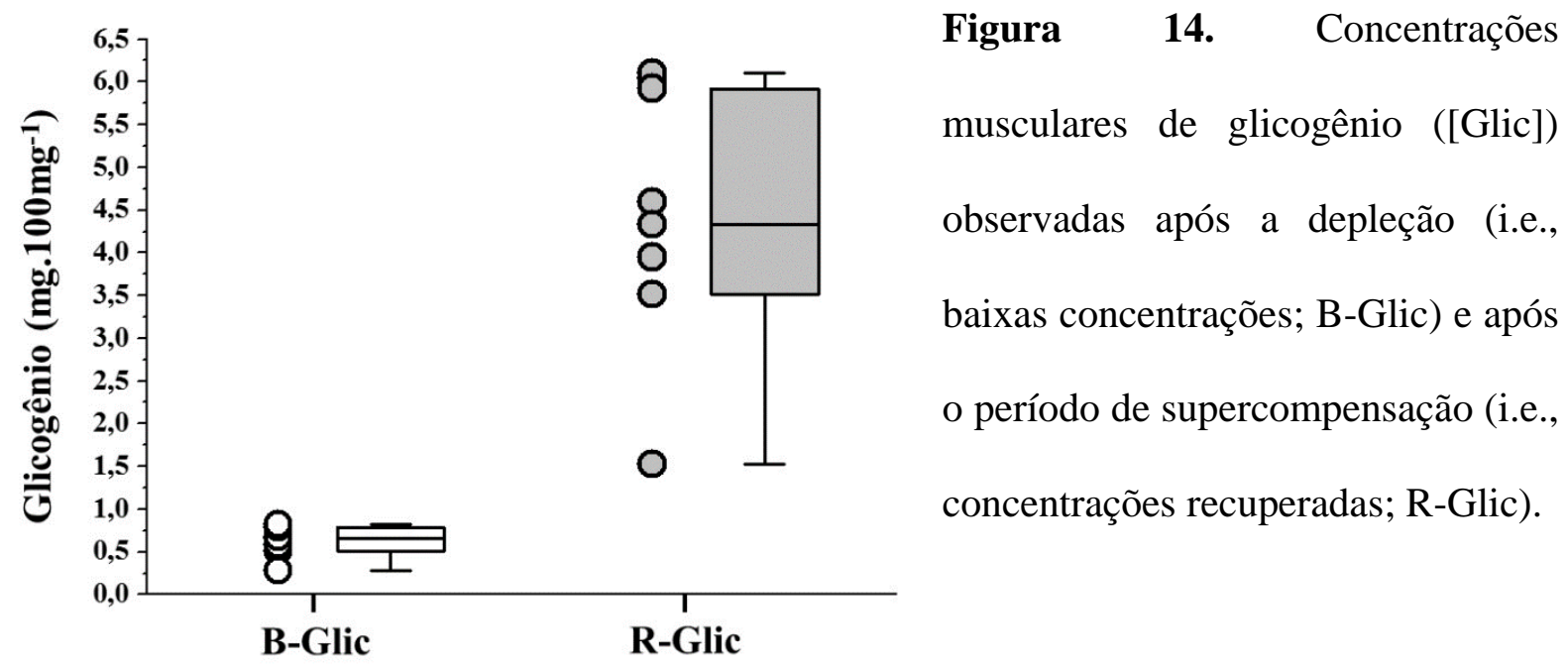

Respostas ao E30Tlim

Os desempenhos ao longo dos esforços de 15 min e durante o esforço até a exaustão, estão apresentados na Figura 15. Na situação R-Glic os participantes apresentaram valores significativamente inferiores no segundo esforço prolongado em relação ao primeiro esforço ( $p$-valor > 0,12). Entretanto, o desempenho foi significativamente superior durante o esforço exaustivo na situação R-Glic, em comparação aos valores observados na B-Glic ( $p$-valor < 0,036), comportamento também evidenciado pelos valores de Tlim ( $p$-valor $=0,012)$ (Figura 
16).
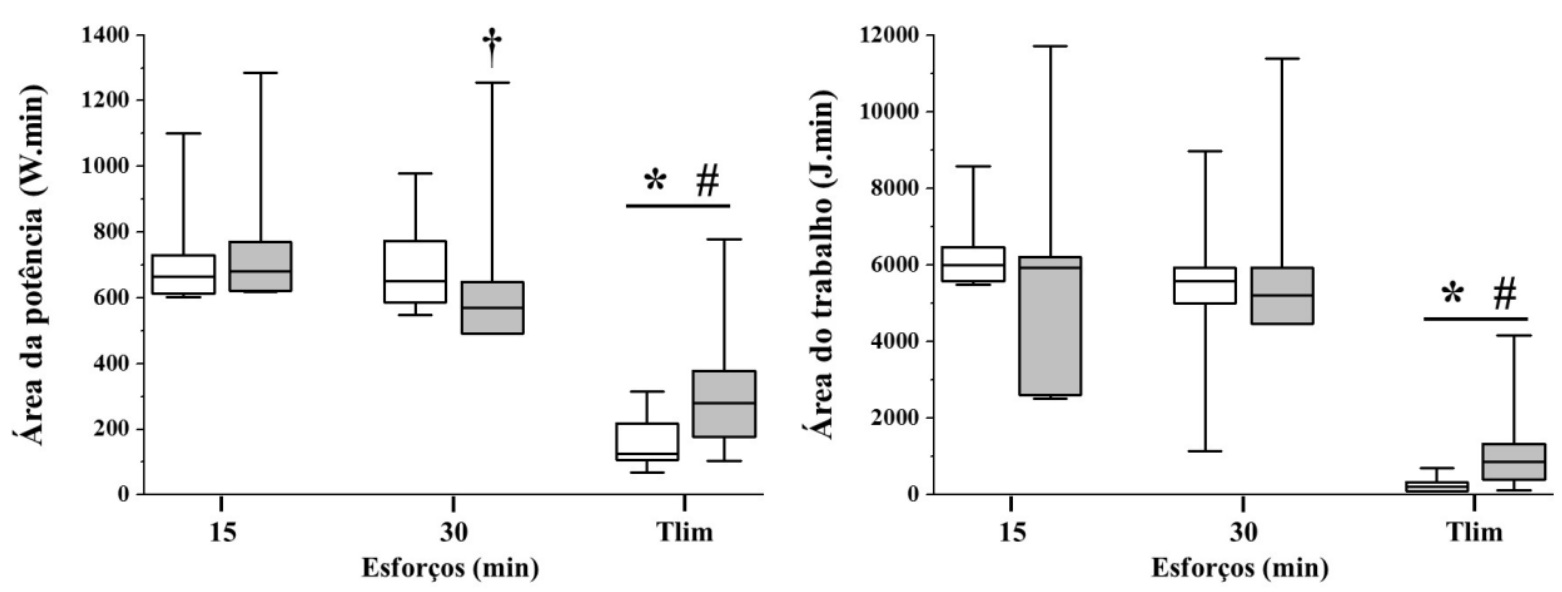

Figura 15. Área sob a curva dos valores de potência e trabalho observados durante dois esforços de 15 min com intensidade correspondente a $80 \%$ da $\mathrm{iVO}_{2 \mathrm{PICO}}$ (E1 e E2) e no esforço até a exaustão realizado a $80 \%$ da $\mathrm{iVO}_{2 \mathrm{PICO}}$. As barras cheias representam a situação onde o glicogênio muscular foi recuperado (R-Glic) e os valores obtidos na situação onde os scores apresentaram baixos valores (B-Glic) estão apresentados nas barras vazias. $\dagger$ : Diferença significativa em relação ao primeiro esforço; *: Diferença significativa entre situações; \#: Diferença significativa em relação ao primeiro esforço para as duas situações. 


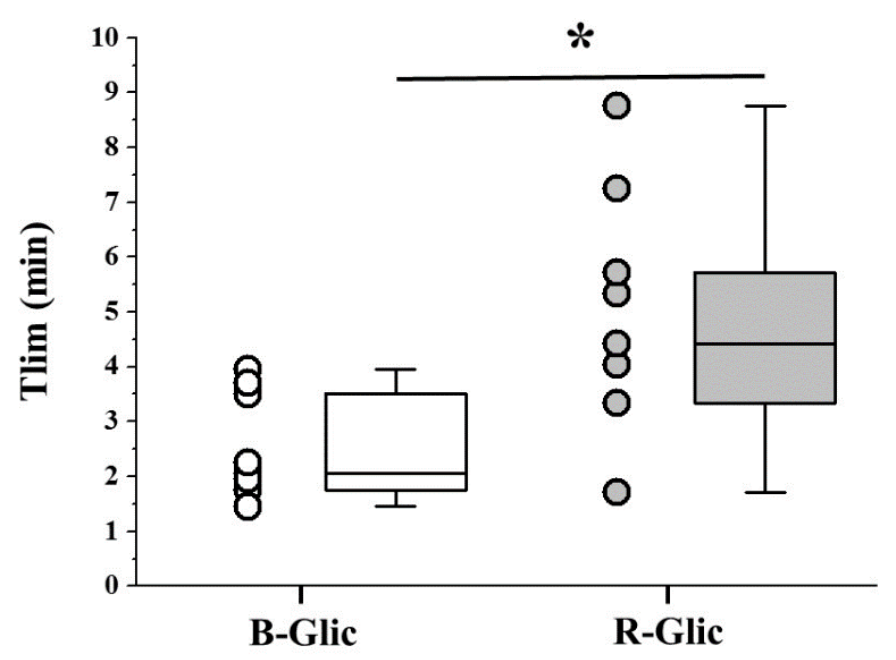

Figura 16. Tempo até a exaustão (Tlim) no esforço correspondente a $80 \%$ da máxima intensidade atingida durante um teste incremental, realizado após dois esforços de 15 min.

Para ambas as situações, os valores de $\mathrm{VE}, \mathrm{VO}_{2}$ e $\mathrm{VCO}_{2}$ apresentaram valores superiores durante o esforço exaustivo em comparação aos observados nos esforços de 15 min ( $p$-valor < 0,012). Os valores de QR foram significativamente inferiores após o segundo esforço em comparação ao primeiro e ao realizado até a exaustão ( $p$-valor $<0,016)$. A VE e o $\mathrm{VO}_{2}$ foram significativamente superiores na situação B-Glic após o esforço até a exaustão ( $p$-valor < 0,012). Além disso, o $\mathrm{VCO}_{2}$ e o $\mathrm{QR}$, apresentaram valores significativamente inferiores na situação B-Glic durante no primeiro esforço e após o esforço até a exaustão ( $p$-valor < 0,036). Estas repostas ventilatórias estão apresentadas na Figura 17. 

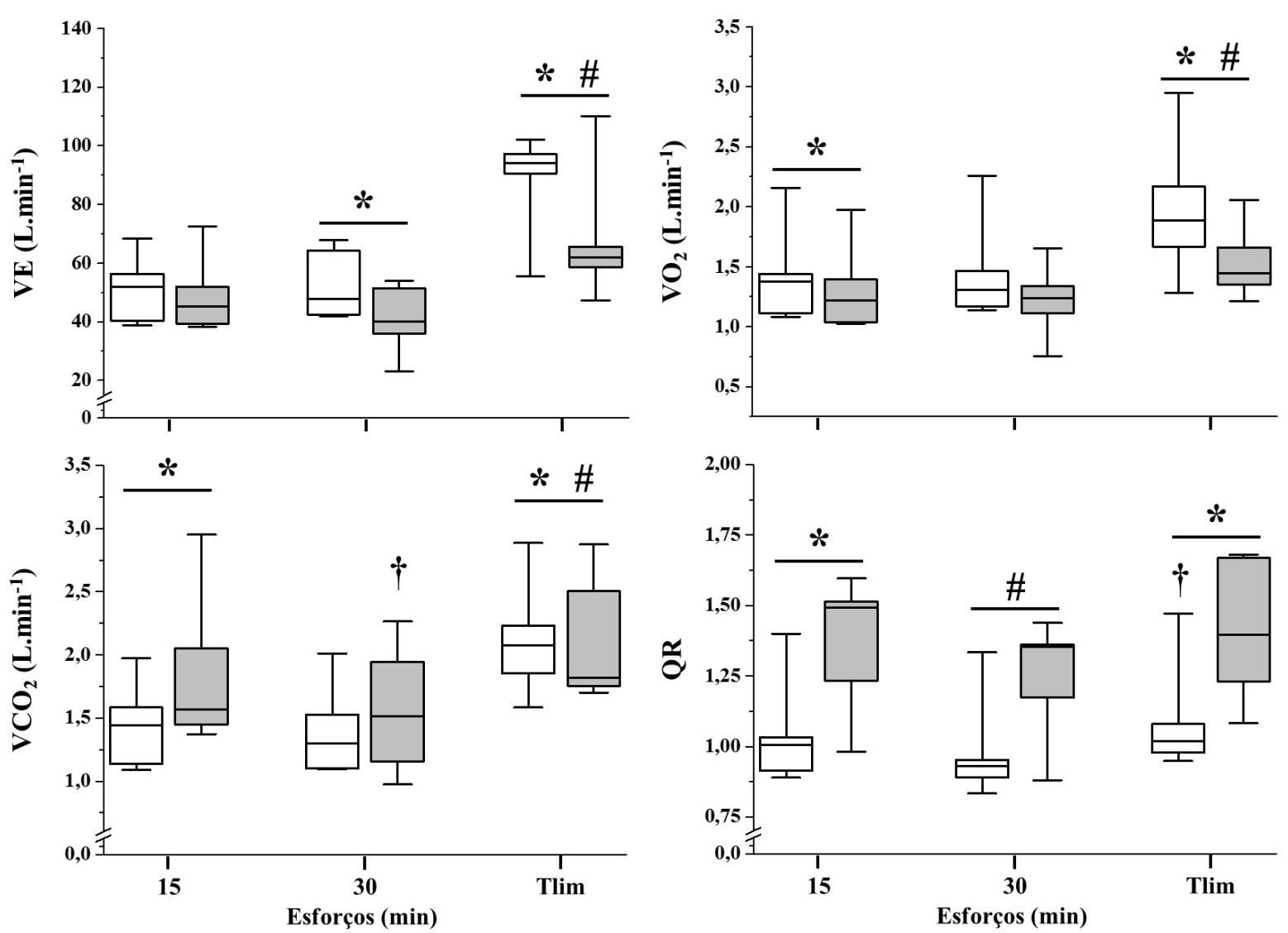

Figura 17. Comportamento das variáveis ventilatórias ao longo de dois esforços de 15 min (E1 e E2) seguidos de um esforço até a exaustão (Tlim). As barras cheias representam a situação onde o glicogênio muscular foi recuperado (R-Glic) e os valores obtidos na situação onde os scores apresentaram baixos valores (B-Glic) estão apresentados nas barras vazias. $\uparrow$ : Diferença significativa em relação ao primeiro esforço; *: Diferença significativa entre situações; \#: Diferença significativa em relação ao primeiro esforço para as duas situações.

Os parâmetros provenientes da técnica de TI estão apresentados na Figura 18. A TS não apresentou diferenças significativas ao longo do exercício realizado, independentemente da situação prévia de glicogênio ( $p$-valor < 0,017). Entretanto, os valores de TP observados antes do exercício foram significativamente superiores a todos os outros momentos na situação BGlic ( $p$-valor < 0,012), o que não ocorreu na situação R-Glic ( $p$-valor > 0,16). Os valores de FP 
foram inferiores ao repouso em todos os momentos da situação B-Glic ( $p$-valor < 0,025), mas durante a situação R-Glic somente os valores após o esforço exaustivo foram significativamente inferiores ao repouso ( $p$-valor $<0,012)$. Além disso, a FP foi significativamente inferior após o primeiro esforço na situação B-Glic em relação a R-Glic (p-valor < 0,012). A AV não foi alterada ao longo do exercício em nenhuma das situações ( $p$-valor > 0,08).

A RMS foi significativamente superior na situação R-Glic em relação a B-Glic, desde o primeiro esforço $(p$-valor $<0,014)$. Estas diferenças também foram observadas para a onda $\mathrm{M}$ após o segundo esforço prolongado, sendo os valores da B-Glic inferiores aos apresentados no repouso e durante a situação R-Glic ( $p$-valor $<0,02$ ). Com isso, a razão RMS/Onda M foi superior ao repouso na situação B-Glic, após o segundo esforço prolongado ( $p$-valor $=0,03)$. As respostas da eletromiografia observada durante a TI estão apresentadas a Figura 19. 

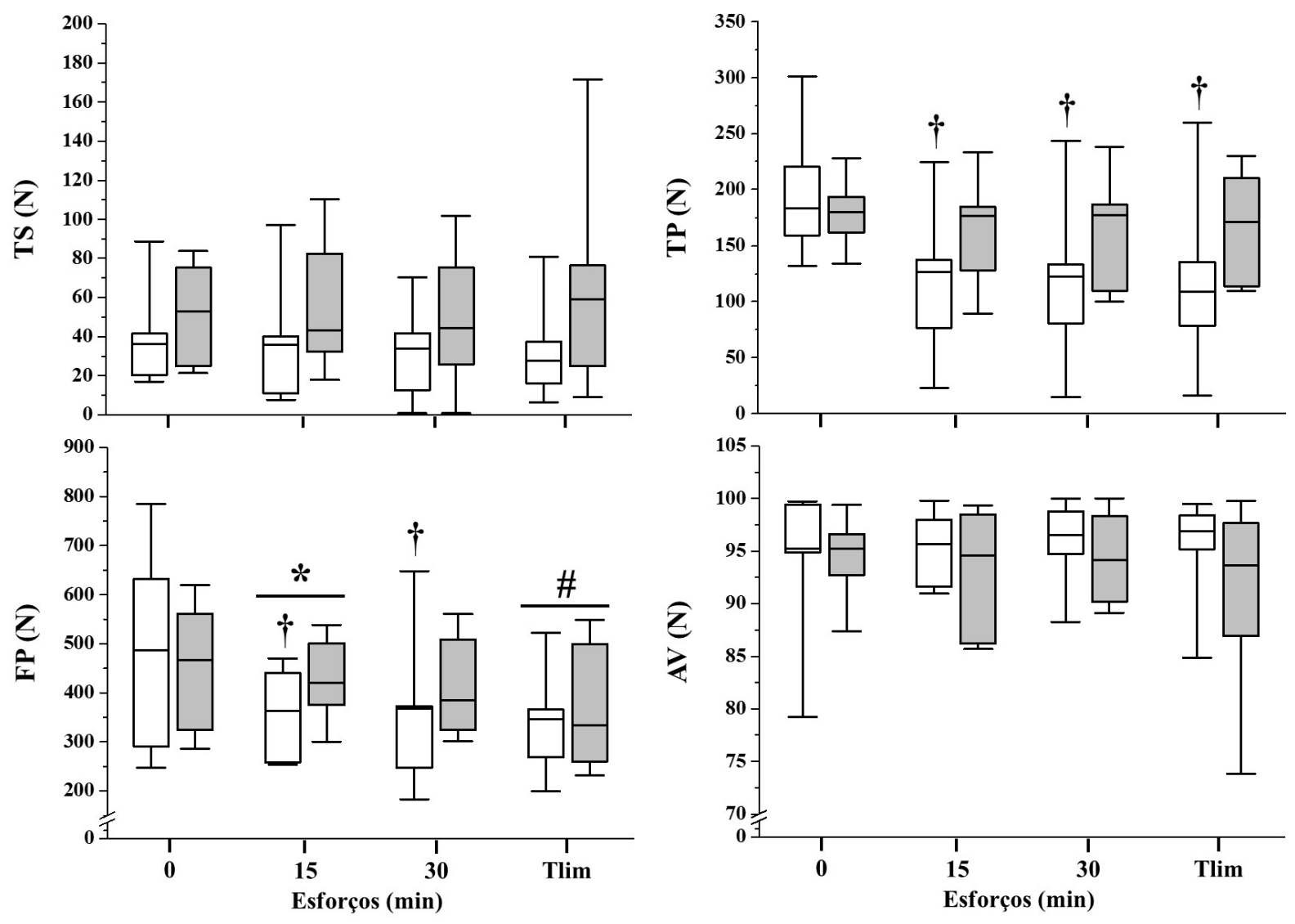

Figura 18. Comportamento das variáveis obtidas por meio dos sinais de força durante a técnica de Twitch Interpolation, após dois esforços de 15 min (E1 e E2) seguidos de um esforço até a exaustão (Tlim). As barras cheias representam a situação onde o glicogênio muscular foi recuperado (R-Glic) e os valores obtidos na situação onde os scores apresentaram baixos valores (B-Glic) estão apresentados nas barras vazias. $\uparrow$ : Diferença significativa em relação ao primeiro esforço; *: Diferença significativa entre situações; \#: Diferença significativa em relação ao primeiro esforço para as duas situações. TS: força evocada com o estímulo elétrico durante a contração isométrica máxima; TP: força evocada com o estímulo elétrico aplicado no músculo relaxado; FP: Força pico; AV: ativação voluntária obtida por meio desta técnica. 


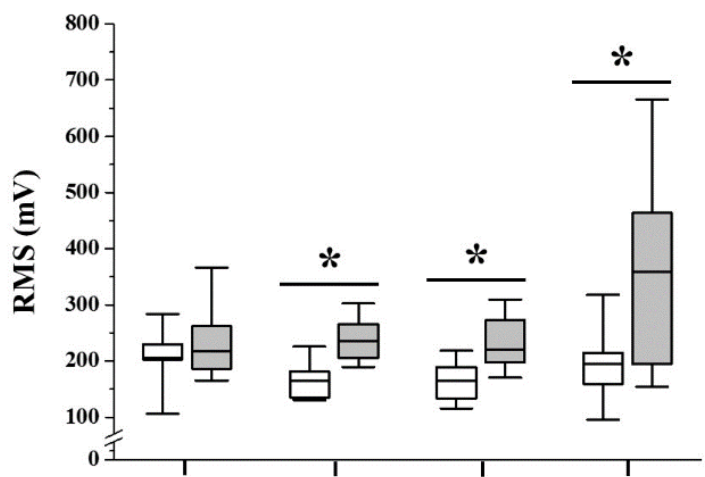

Figura 19. Respostas obtidas com a eletromiografia de superfície durante a técnica de Twitch Interpolation, após dois esforços de 15 min (E1 e E2) seguidos de um esforço até a exaustão (Tlim). As barras cheias representam a

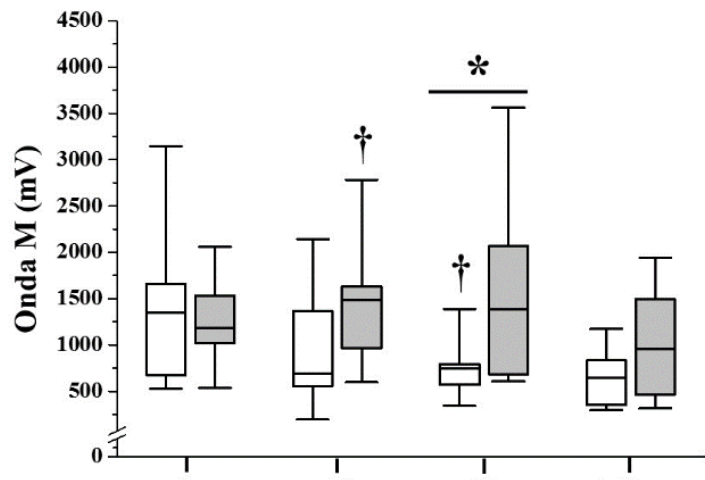
situação onde o glicogênio muscular foi recuperado (R-Glic) e os valores obtidos na situação onde os scores apresentaram baixos valores (B-Glic) estão apresentados nas barras vazias. $\dagger$ : Diferença significativa em relação ao primeiro esforço; *: Diferença significativa entre

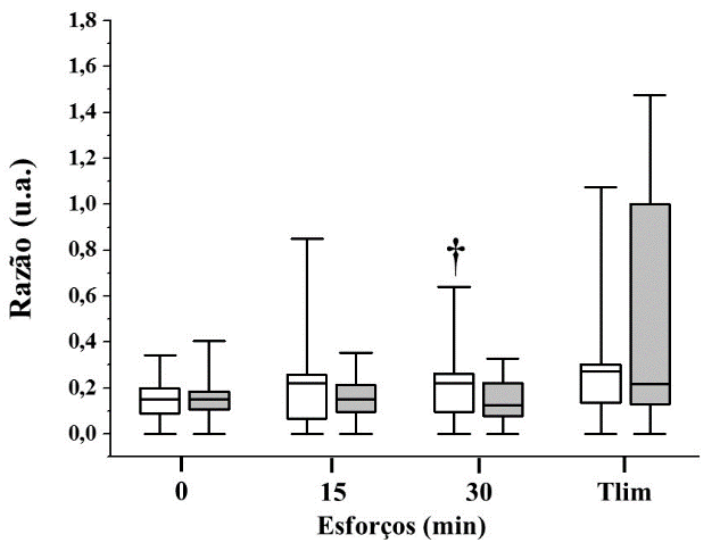
situações; \#: Diferença significativa em relação ao primeiro esforço para as duas situações. RMS: Root mean square.

As concentrações de TrP diminuíram significativamente após o exercício realizado na situação R-Glic ( $p$-valor $>0,01)$, o que não ocorreu na B-Glic ( $p$-valor $>0,20)$ (Figura 20). A Tabela 1 demonstra os coeficientes de correlação entre as concentrações de TrP e os parâmetros relacionados a fadiga central e periférica obtidos pela técnica de Twitch Interpolation no E30Tlim. Foram observadas relações diretas entre as concentrações de TrP e a TS observada no primeiro esforço somente na situação B-Glic $(p=0,02)$. Neste mesmo esforço e situação, relações inversas foram observadas entre o $\operatorname{TrP}$ e a AV $(\mathrm{p}=0,01)$. Relações diretas foram 
observadas entre o TrP e o Tp-p no repouso do situação R-Glic $(p=0,01)$. A variação percentual da força foi diretamente relacionada ao TrP no domínio pesado na situação R-Glic ( $p=0,04)$.

As concentrações de glicose foram significativamente inferiores após o segundo esforço contínuo, somente na situação R-Glic ( $p$-valor $=0,03)$. As concentrações de lactato aumentaram após todos os esforços em relação ao repouso ( $p$-valor $>0,01)$, sem diferenças significativas entre as situações ( $p$-valor $>0,10)$. A Figura 21 demonstra o comportamento da glicose e do lactato durante este esforço de duração moderada.

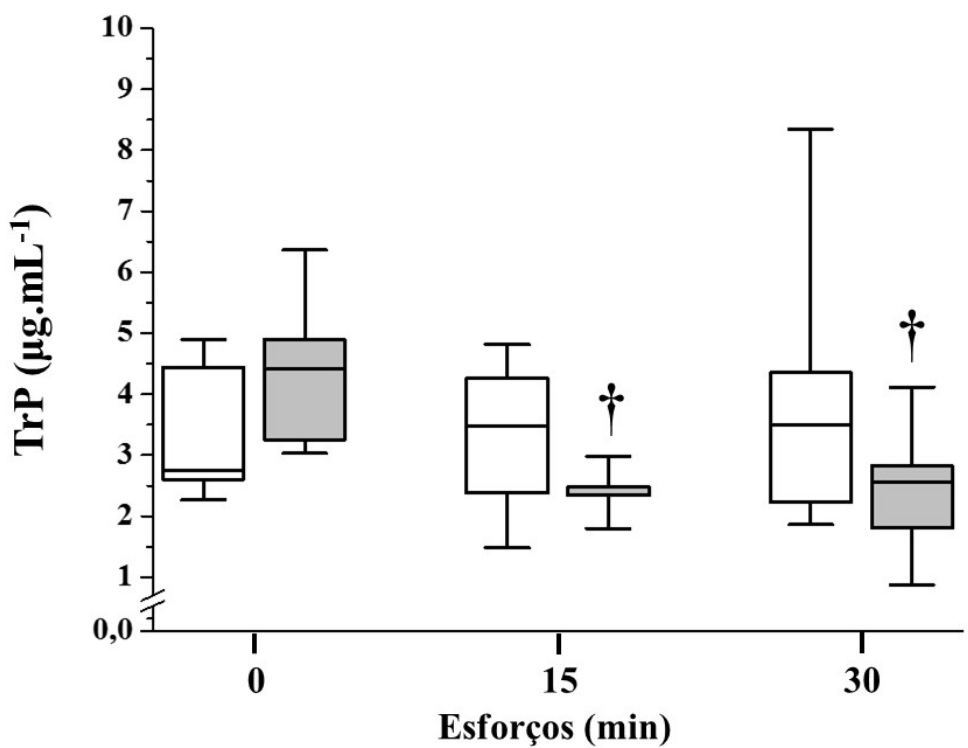

Figura 20. Comportamento das concentrações plasmáticas de triptofano (TrP) ao longo do exercício de interesse. As barras cheias representam a situação onde o glicogênio muscular foi recuperado (R-Glic) e os valores obtidos na situação onde os scores

apresentaram baixos valores (B-Glic) estão apresentados nas barras vazias. $\dagger$ : Diferença significativa em relação ao primeiro esforço. 
Tabela 1. Relações entre as concentrações sanguíneas de triptofano livre (TrP) e os parâmetros obtidos pela técnica de Twitch Interpolation - em valores absolutos e em variações percentuais $(\Delta)$ - durante o E30Tlim, nas situações de baixo conteúdo de glicogênio (B-Glic) e com o glicogênio recuperado (R-Glic).

\begin{tabular}{|c|c|c|c|c|c|c|c|c|}
\hline & \multicolumn{4}{|l|}{ B-Glic } & \multicolumn{4}{|l|}{ R-Glic } \\
\hline & Repouso & E1 & E2 & $\Delta$ & Repouso & E1 & E2 & $\Delta$ \\
\hline $\mathrm{TS}$ & 0,33 & $0,81^{*}$ & 0,24 & $-0,16$ & $-0,43$ & $-0,41$ & $-0,19$ & 0,26 \\
\hline $\mathrm{TC}$ & 0,59 & 0,49 & 0,28 & $-0,07$ & $-0,52$ & $-0,02$ & $-0,32$ & $-0,06$ \\
\hline FP & 0,52 & 0,38 & 0,19 & $-0,41$ & 0,51 & 0,01 & $-0,04$ & $-0,41$ \\
\hline $\mathrm{AV}$ & 0,45 & - $0,87 *$ & $-0,14$ & $-0,30$ & 0,53 & 0,52 & 0,31 & 0,08 \\
\hline
\end{tabular}

TS: força evocada pela estimulação elétrica durante a contração máxima; TC: força evocada pela estimulação elétrica após a contração máxima; FP: força pico observada durante a contração isométrica; AV: ativação voluntária.

Tabela 2. Relações entre as concentrações sanguíneas de triptofano livre (TrP) e os parâmetros obtidos pela técnica de Estimulação magnética transcraniana - em valores absolutos e em variações percentuais $(\Delta)$ - durante o E30Tlim, nas situações de baixo conteúdo de glicogênio (B-Glic) e com o glicogênio recuperado (R-Glic).

\begin{tabular}{|c|c|c|c|c|c|c|c|c|}
\hline & B-Glic & & & & R-Glic & & & \\
\hline & Repouso & E1 & E2 & $\Delta$ & Repouso & E1 & $\mathrm{E} 2$ & $\Delta$ \\
\hline Amp & ---- & ---- & ---- & ---- & $-0,41$ & 0,12 & 0,25 & 0,41 \\
\hline $\mathrm{Tp}-\mathrm{p}$ & ---- & ---- & ---- & ---- & $0,89 *$ & 0,19 & 0,13 & 0,17 \\
\hline Tsil & ---- & ---- & ---- & ---- & $-0,27$ & $-0,46$ & $-0,01$ & $-0,30$ \\
\hline Força & ---- & ---- & ---- & ---- & 0,18 & 0,08 & 0,68 & $0,89 *$ \\
\hline
\end{tabular}

Amp: Amplitude do sinal observado pela análise de EMG no momento do estímulo magnético; Tp-p: tempo entre o pico positivo e o pico negativo observados pela análise de EMG no momento do estímulo magnético; Tsil: tempo para que o sinal de EMG retorne ao comportamento normal durante uma contração submáxima após o estímulo magnético; Força: força evocada com o estímulo magnético; ----: análise não realizada pelo baixo número de 
respostas satisfatórias $(\mathrm{n}=2)$.
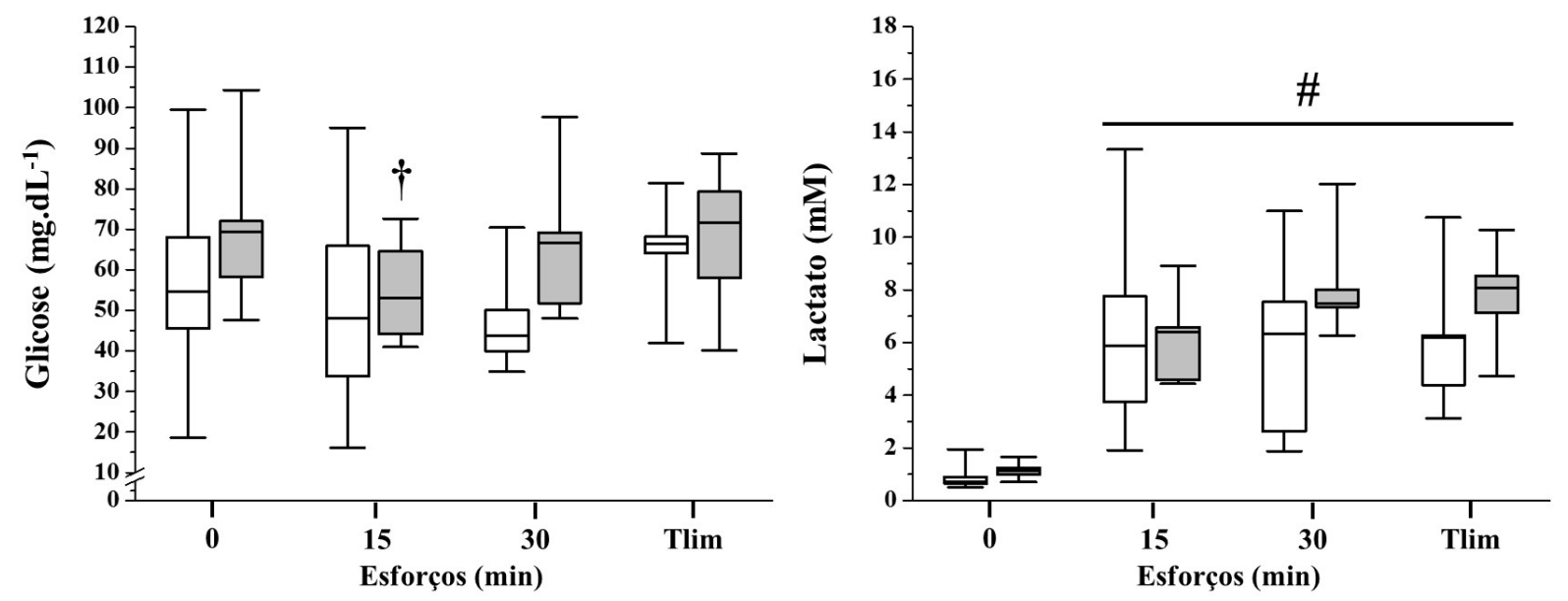

Figura 21. Comportamento das concentrações de glicose e lactato ao longo do exercício de interesse. As barras cheias representam a situação onde o glicogênio muscular foi recuperado (R-Glic) e os valores obtidos na situação onde os scores apresentaram baixos valores (B-Glic) estão apresentados nas barras vazias. $\uparrow$ : Diferença significativa em relação ao primeiro esforço; \#: Diferença significativa em relação ao primeiro esforço para as duas situações.

\section{Respostas ao E40Tlim}

Diferentemente do E30Tlim, durante o esforço de longa duração o desempenho na situação B-Glic foi significativamente inferior ao observado na R-Glic ( $p$-valor < 0,03), o que também ocorreu durante o esforço até a exaustão ( $p$-valor $=0,001)$. Além disso, durante a RGlic, o segundo esforço apresentou desempenho significativamente inferior ao primeiro ( $p$ valor $=0,02)$. O Tlim também foi inferior na situação B-Glic $(p$-valor $=0,01)$. Estas respostas estão apresentadas na Figura 22 e 23. 

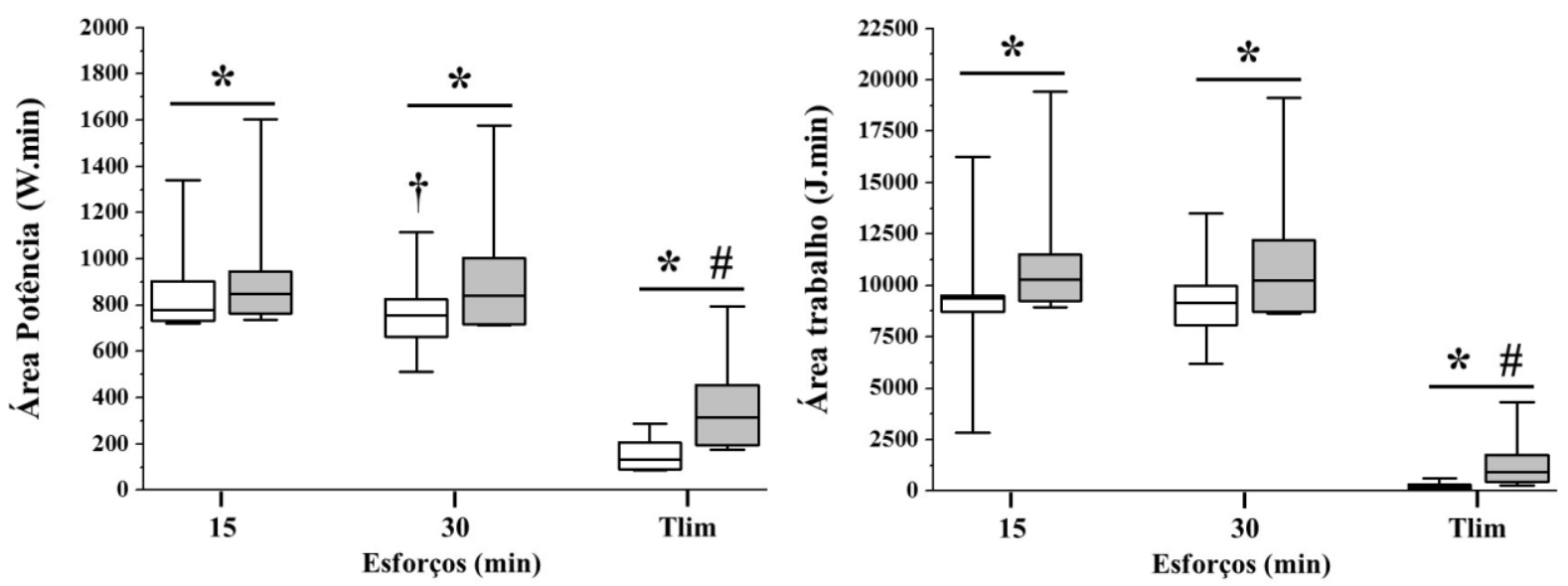

Figura 22. Área sob a curva dos valores de potência e trabalho observados durante dois esforços de 20 min com intensidade correspondente a 70\% da iVO2PICo (E1 e E2) e no esforço até a exaustão realizado nessa intensidade. As barras cheias representam a situação onde o glicogênio muscular foi recuperado (R-Glic) e os valores obtidos na situação onde os scores apresentaram baixos valores (B-Glic) estão apresentados nas barras vazias. $\dagger$ : Diferença significativa em relação ao primeiro esforço; *: Diferença significativa entre situações; \#: Diferença significativa em relação ao primeiro esforço para as duas situações.

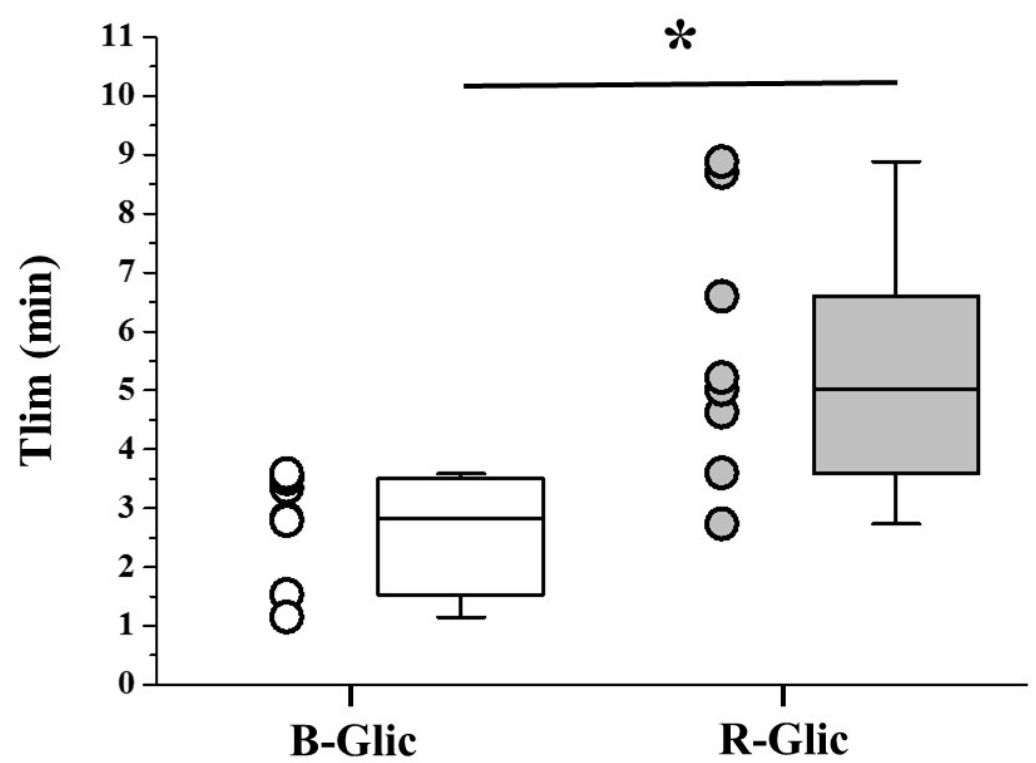

Figura 23. Tempo até a exaustão (Tlim) no esforço correspondente a $80 \%$ da máxima intensidade atingida durante um teste incremental, realizado após dois esforços de 20 min a $70 \%$ da máxima intensidade atingida no teste incremental.

Os valores de $\mathrm{VE}, \mathrm{VO}_{2}$ e $\mathrm{VCO}_{2}$, foram significativamente superiores nos esforços até a 
exaustão realizado em ambas as situações ( $p$-valor $<0,012)$ (Figura 23). Além disso, os independentemente da situação, os valores de QR foram inferiores após o segundo esforço em relação aos demais ( $p$-valor < 0,016). Todas as variáveis ventilatórias não apresentaram diferenças significativas entre as situações ( $p$-valor > 0,32) (Figura 24).
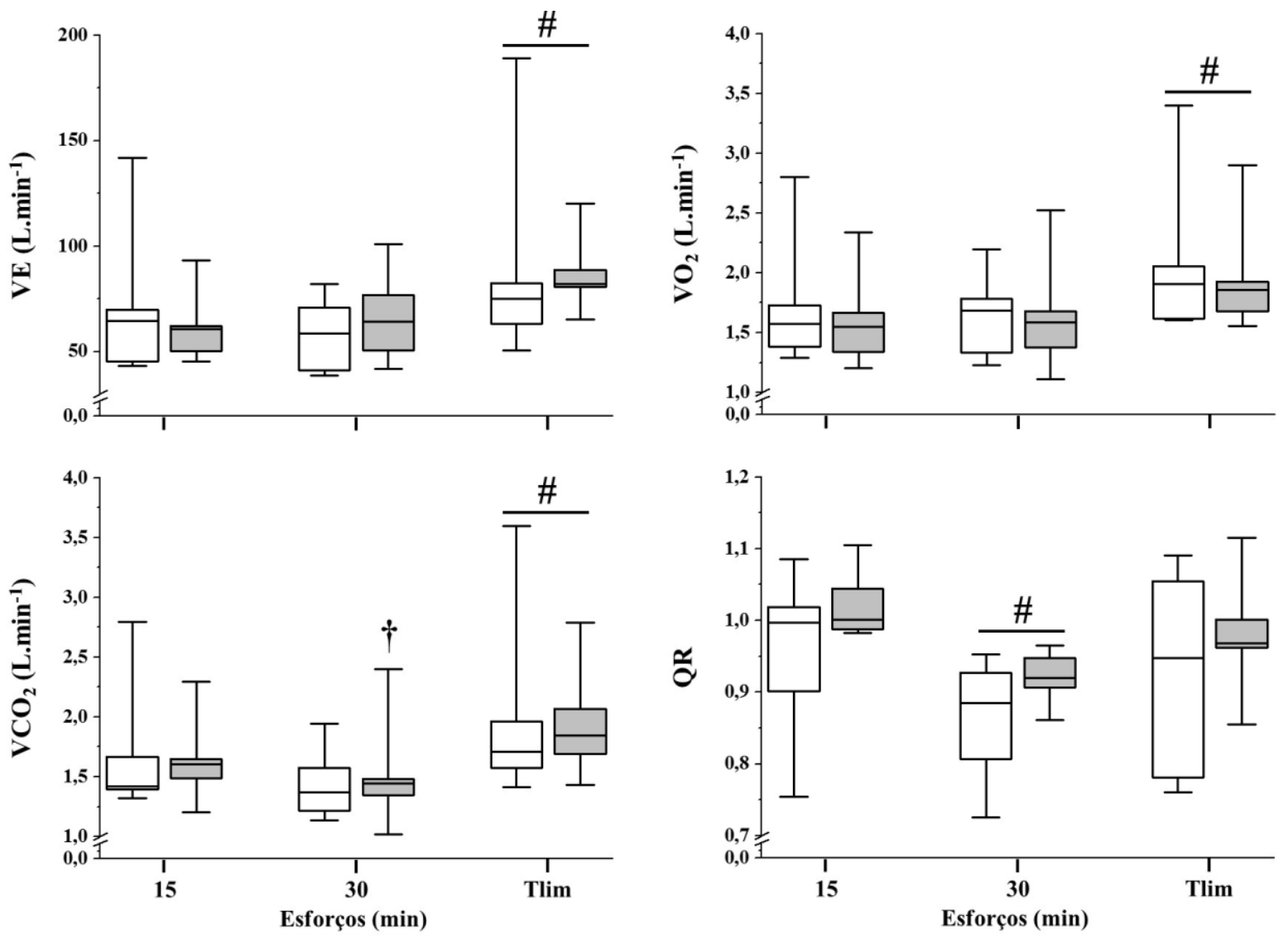

Figura 24. Comportamento das variáveis ventilatórias ao longo de dois esforços de 20 min (E1 e E2) seguidos de um esforço até a exaustão (Tlim). As barras cheias representam a situação onde o glicogênio muscular foi recuperado (R-Glic) e os valores obtidos na situação onde os scores apresentaram baixos valores (B-Glic) estão apresentados nas barras vazias. $\uparrow$ : Diferença significativa em relação ao primeiro esforço; *: Diferença significativa entre situações; \#: Diferença significativa em relação ao primeiro esforço para as duas situações.

A TS apresentou uma diminuição significativa a partir do primeiro esforço na situação B- 
Glic ( $p$-valor < 0,016), o que não apresentou significância na situação R-Glic ( $p$-valor > 0,17). A TP observada no repouso foi significativamente superior a todos os outros momentos na situação B-Glic ( $p$-valor < 0,012). Na situação R-Glic, uma manutenção da TP ocorreu durante o primeiro esforço (i.e., diminuições significativas apenas após o segundo esforço e imediatamente após a exaustão; p-valor $<0,012)$. A força pico observada no repouso foi superior a todos os outros momentos, independentemente da situação estudada ( $p$-valor < 0,032). Esta diminuição na FP foi mais acentuada na B-Glic, que apresentou valores significativamente inferiores a R-Glic após os dois esforços de $20 \mathrm{~min}(p$-valor $<0,02)$. A AV não foi alterada ao longo dos esforços, em ambas as situações ( $p$-valor $>0,22)$. Todos os comportamentos observados para as variáveis da técnica de TI estão apresentados na Figura 25.

A RMS aumentou significativamente desde o segundo esforço contínuo na situação RGlic, o que perdurou até o final do esforço exaustivo ( $p$-valor $<0,03$ ). Na situação B-Glic a RMS aumentou somente após o esforço exaustivo $(p$-valor $=0,02)$. Na situação B-Glic a Onda M aumentou após o primeiro esforço em relação aos valores de repouso ( $p$-valor $=0,01)$, o que não ocorreu na R-Glic. A razão RMS/Onda M diminuiu após o segundo esforço e, após o esforço exaustivo, aumentou significativamente na situação B-Glic ( $p$-valor $=0,03$ ), o que não ocorreu na R-Glic ( $p$-valor $>0,11)$. As respostas da eletromiografia obtida durante a aplicação da técnica de TI estão apresentadas na Figura 26. 

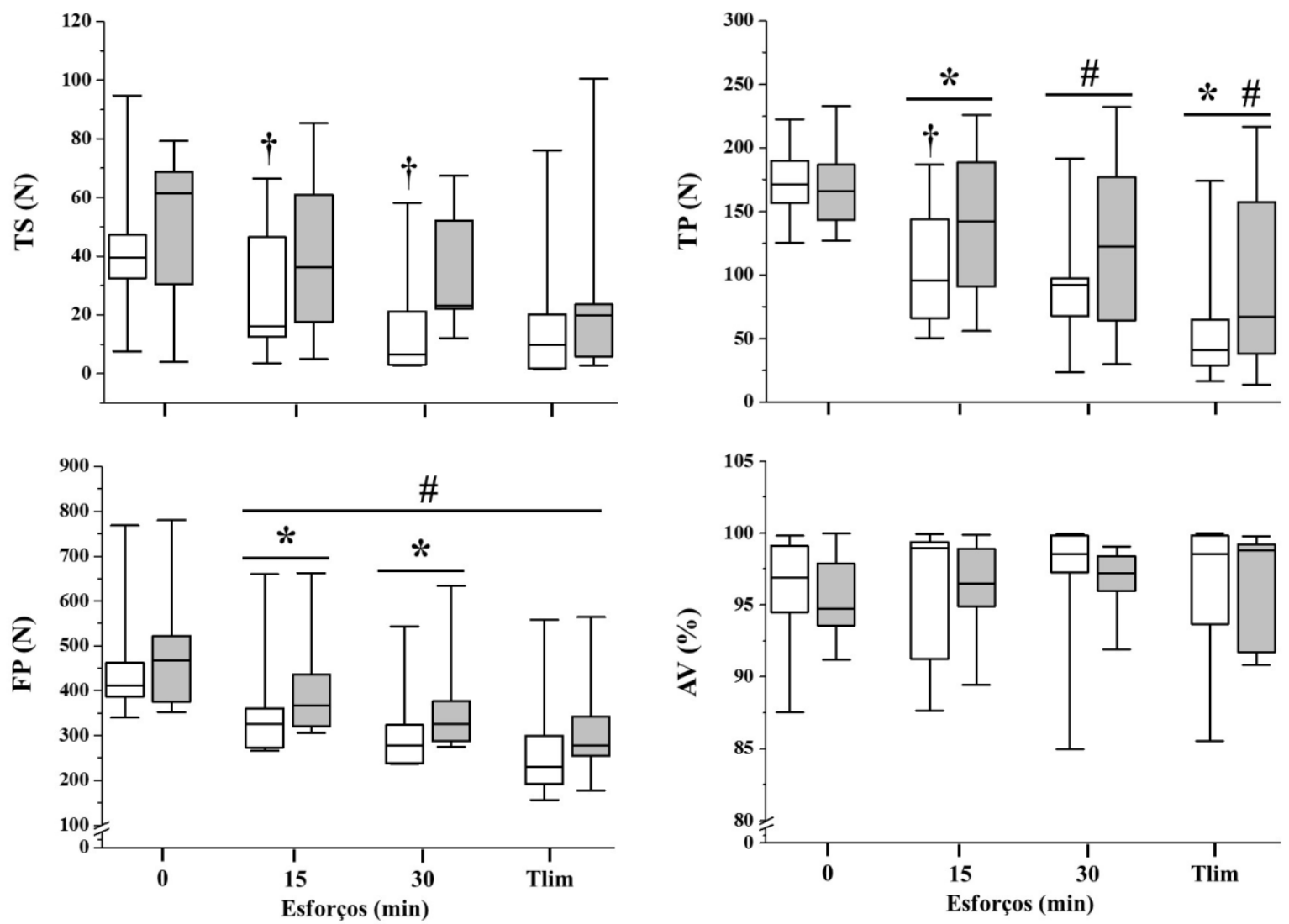

Figura 25. Comportamento das variáveis obtidas por meio dos sinais de força durante a técnica de Twitch Interpolation, após dois esforços de 20 min (E1 e E2) seguidos de um esforço até a exaustão (Tlim). As barras cheias representam a situação onde o glicogênio muscular foi recuperado (R-Glic) e os valores obtidos na situação onde os scores apresentaram baixos valores (B-Glic) estão apresentados nas barras vazias. †: Diferença significativa em relação ao primeiro esforço; *: Diferença significativa entre situações; \#: Diferença significativa em relação ao primeiro esforço para as duas situações. TS: força evocada com o estímulo elétrico durante a contração isométrica máxima; TP: força evocada com o estímulo elétrico aplicado no músculo relaxado; FP: Força pico; AV: ativação voluntária obtida por meio desta técnica. 

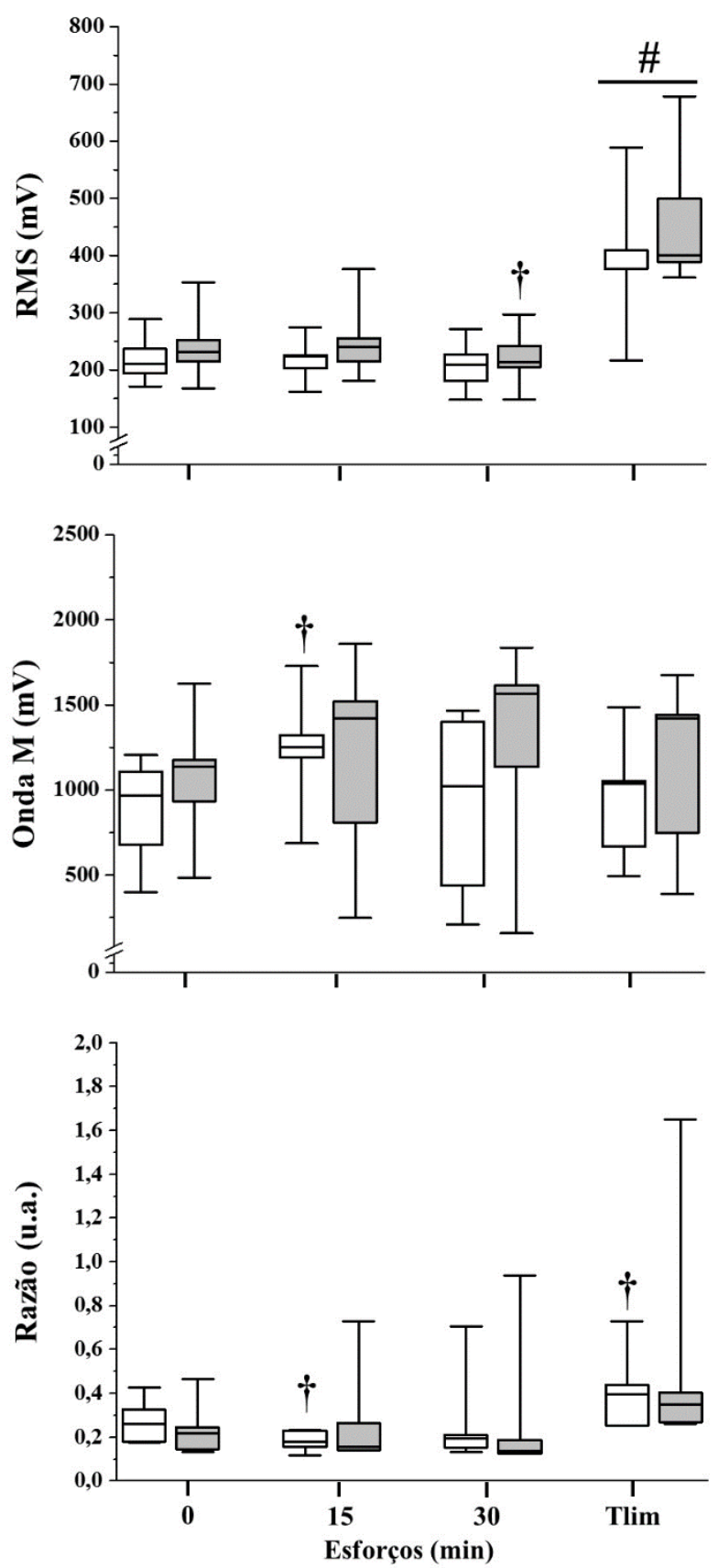

Figura 26. Respostas obtidas com a eletromiografia de superfície durante a técnica de Twitch Interpolation, após dois esforços de 20 min (E1 e E2) seguidos de um esforço até a exaustão (Tlim). As barras cheias representam a situação onde $\mathrm{o}$ glicogênio muscular foi recuperado (RGlic) e os valores obtidos na situação onde os scores apresentaram baixos valores (BGlic) estão apresentados nas barras vazias. †: Diferença significativa em relação ao primeiro esforço; *: Diferença significativa entre situações; \#: Diferença significativa em relação ao primeiro esforço para as duas situações. RMS: Root mean square. 

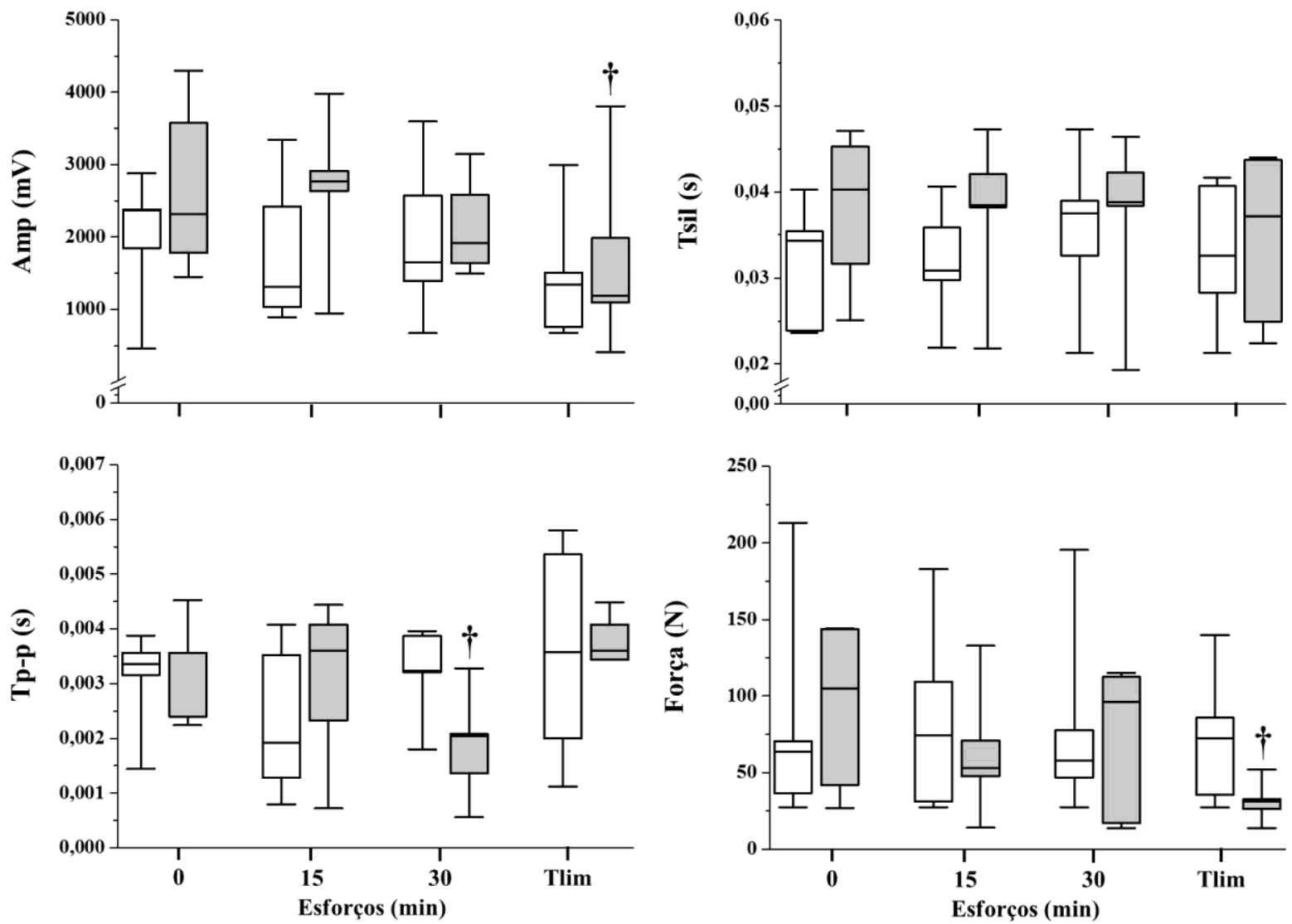

Figura 27. Parâmetros obtidos pela técnica de estimulação magnética tranascraniana (EMT). As barras cheias representam a situação onde o glicogênio muscular foi recuperado (R-Glic) e os valores obtidos na situação onde os scores apresentaram baixos valores (B-Glic) estão apresentados nas barras vazias. Amp: Amplitude do sinal observado pela análise de EMG no momento do estímulo magnético; Tp-p: tempo entre o pico positivo e o pico negativo observados pela análise de EMG no momento do estímulo magnético; Tsil: tempo para que o sinal de EMG retorne ao comportamento normal durante uma contração submáxima após o estímulo magnético; Força: força evocada com o estímulo magnético; †: Diferença significativa em relação ao primeiro esforço.

As concentrações de TrP no repouso foram significativamente superiores na situação RGlic em comparação a B-Glic ( $p$-valor > 0,01). Durante o exercício proposto, as concentrações 
de TrP diminuíram significativamente $(p$-valor $>0,02)$, sem diferenças entre as situações $(p$ valor > 0,11) (Figura 25). No E30Tlim, as concentrações de TrP foram inversamente relacionadas a AV observada após o segundo esforço da situação B-Glic ( $p=0,03)$. Nenhuma relação foi observada entre o TrP e os parâmetros de fadiga observados em ambos os domínios fisiológicos na situação R-Glic ( $p$ > 0,10). Neste esforço foi possível a investigação das relações entre o TrP e os parâmetros da técnica de EMT (Tabela 3). O TrP apresentou correlações significativas com o tempo de silêncio após o segundo esforço na situação B-Glic ( $p$-value = 0,01). Na situação R-Glic o TrP foi correlacionado com o tempo entre os picos observado no repouso $(p$-value $=0,02)$.

As concentrações de glicose na B-Glic foram significativamente menores após o esforço exaustivo tanto em relação ao repouso $(p$-valor $=0,01)$ como em comparação com R-Glic ( $p$ valor $=0,01)$. As concentrações de lactato aumentaram significativamente ao longo do exercício, em ambas as situações ( $p$-valor $<0,03$ ). Entretanto, durante os esforços realizados na B-Glic as concentrações de lactato foram significativamente inferiores aos valores observados em R-Glic ( $p$-valor > 0,01). O comportamento da glicose e do lactato ao longo dos esforços está apresentado na Figura 26.

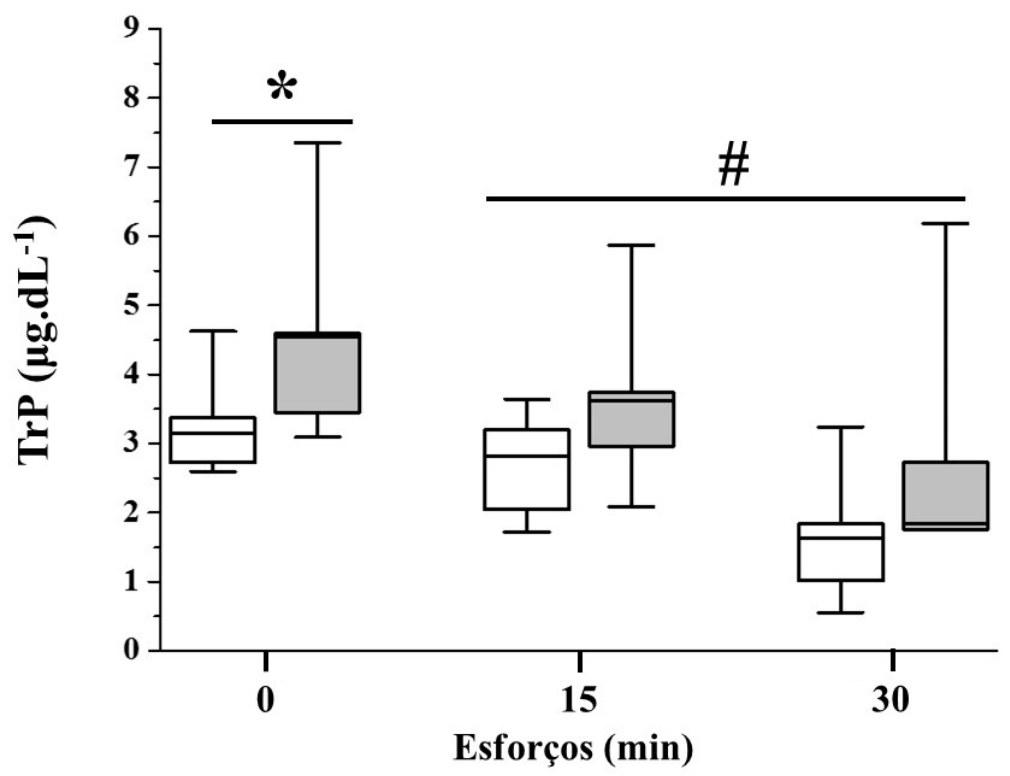

Figura 25. Comportamento das concentrações plasmáticas de triptofano $(\mathrm{TrP})$ ao longo do exercício de interesse. As barras cheias representam a situação onde o glicogênio muscular foi recuperado (R-Glic) e os valores obtidos na situação onde os 
scores apresentaram baixos valores (B-Glic) estão apresentados nas barras vazias. $\uparrow$ : Diferença significativa em relação ao primeiro esforço.

Tabela 3. Relações entre as concentrações sanguíneas de triptofano livre (TrP) e os parâmetros obtidos pela técnica de Twitch Interpolation - em valores absolutos e em variações percentuais $(\Delta)$ - durante o E40Tlim, nas situações de baixo conteúdo de glicogênio (B-Glic) e com o glicogênio recuperado (R-Glic).

\begin{tabular}{|c|c|c|c|c|c|c|c|c|}
\hline \multirow[b]{2}{*}{ TS } & \multicolumn{4}{|l|}{ B-Glic } & \multicolumn{4}{|l|}{ R-Glic } \\
\hline & 0,33 & 0,34 & 0,39 & $-0,51$ & $-0,08$ & $-0,14$ & $-0,10$ & 0,03 \\
\hline $\mathrm{TC}$ & $-0,24$ & $-0,52$ & $-0,53$ & $-0,55$ & 0,14 & 0,28 & 0,32 & 0,31 \\
\hline FP & 0,15 & 0,10 & $-0,26$ & $-0,20$ & $-0,23$ & $-0,19$ & $-0,07$ & 0,30 \\
\hline AV & $-0,45$ & $-0,46$ & $-0,76^{*}$ & 0,51 & $-0,24$ & 0,36 & 0,21 & 0,01 \\
\hline
\end{tabular}

TS: força evocada pela estimulação elétrica durante a contração máxima; TC: força evocada pela estimulação elétrica após a contração máxima; FP: força pico observada durante a contração isométrica; AV: ativação voluntária.

Tabela 4. Relações entre as concentrações sanguíneas de triptofano livre (TrP) e os parâmetros obtidos pela técnica de Estimulação magnética transcraniana - em valores absolutos e em variações percentuais $(\Delta)$ durante o E40Tlim, nas situações de baixo conteúdo de glicogênio (B-Glic) e com o glicogênio recuperado (R-Glic).

\begin{tabular}{|c|c|c|c|c|c|c|c|c|}
\hline & \multicolumn{4}{|l|}{ B-Glic } & \multicolumn{4}{|l|}{ R-Glic } \\
\hline & Repouso & E1 & E2 & $\Delta$ & Repouso & E1 & E2 & $\Delta$ \\
\hline Amp & $-0,72$ & $-0,73$ & $-0,57$ & $-0,09$ & 0,27 & 0,31 & 0,71 & 0,15 \\
\hline $\mathrm{Tp}-\mathrm{p}$ & 0,55 & $-0,22$ & $-0,68$ & 0,58 & $0,93 *$ & 0,22 & $-0,43$ & $-0,34$ \\
\hline Tsil & 0,64 & 0,41 & $0,94^{*}$ & $-0,09$ & 0,34 & 0,18 & 0,58 & $-0,40$ \\
\hline Força & $-0,56$ & $-0,72$ & 0,14 & 0,50 & 0,22 & 0,75 & 0,58 & $-0,28$ \\
\hline
\end{tabular}

Amp: Amplitude do sinal observado pela análise de EMG no momento do estímulo magnético; Tp-p: tempo entre o pico positivo e o pico negativo observados pela análise de EMG no momento do estímulo magnético; Tsil: tempo para que o sinal de EMG retorne ao 
comportamento normal durante uma contração submáxima após o estímulo magnético; Força: força evocada com o estímulo magnético.
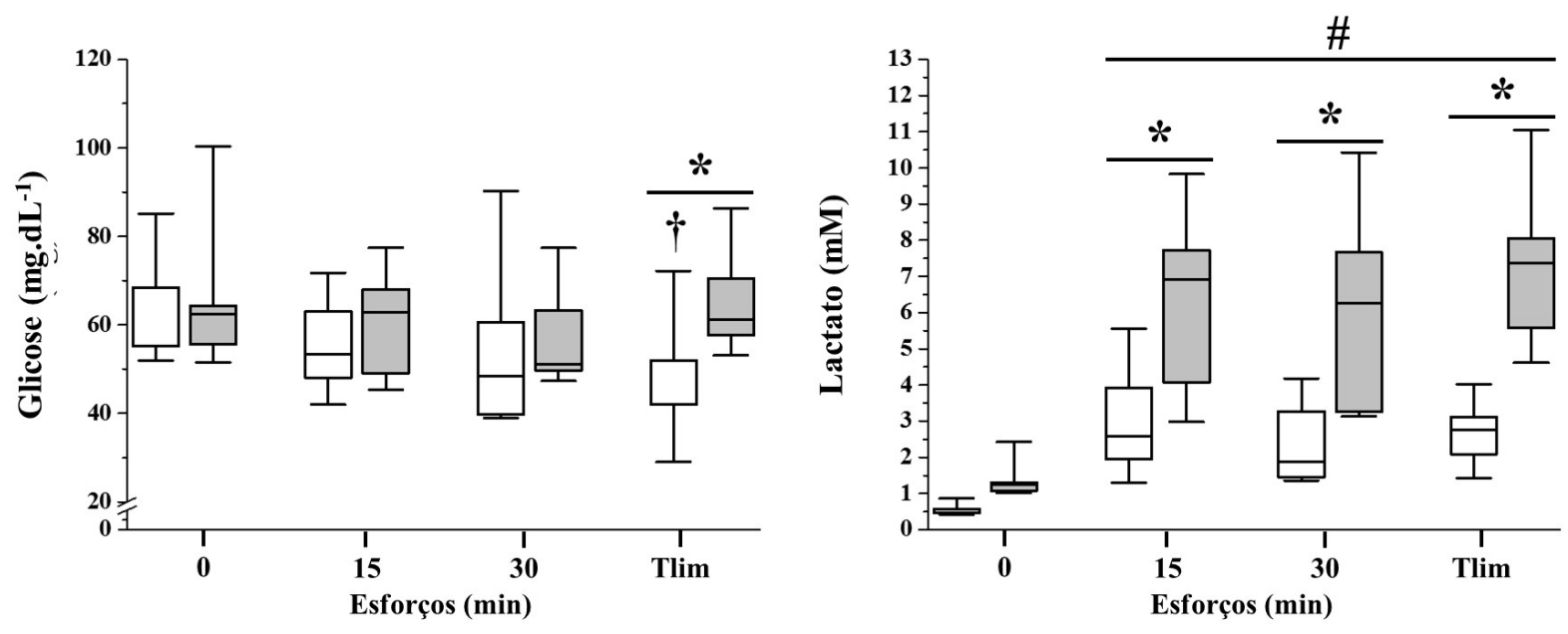

Figura 26. Comportamento das concentrações de glicose e lactato ao longo do exercício de interesse. As barras cheias representam a situação onde o glicogênio muscular foi recuperado (R-Glic) e os valores obtidos na situação onde os scores apresentaram baixos valores (B-Glic) estão apresentados nas barras vazias. †: Diferença significativa em relação ao primeiro esforço; \#: Diferença significativa em relação ao primeiro esforço para as duas situações.

Neste esforço de longa duração foi possível a determinação dos parâmetros provenientes da EMT, os quais estão apresentados na Figura 27. A amplitude (Amp) do sinal de eletromiografia evidenciada com o estímulo magnético, diminuiu significativamente após o esforço exaustivo, apena na R-Glic ( $p$-valor > 0,03). O tempo de silencio (TSil) não foi alterado pelo exercício realizado, independentemente da situação prévia de glicogênio ( $p$-valor > 0,11). O tempo de pico a pico do sinal de eletromiografia (Tp-p), diminuiu significativamente após o segundo esforço da situação R-Glic ( $p$-valor $=0,03$ ), o que não ocorreu durante o exercício realizado em B-Glic (p-valor > 0,18). A força evocada pelos estímulos diminuiu 
significativamente após o esforço exaustivo, apenas na situação R-Glic ( $p$-valor > 0,01).

Relações do $\Delta T r P$ com todos os parâmetros de fadiga independentemente da situação

Quando levamos em consideração todos os esforços em todas as situações e intensidades, nenhuma correlação foi observada entre as concentrações de $\operatorname{TrP}$ e os parâmetros da técnica de Twitch Interpolation (Figura 28). As relações entre as concentrações de $\operatorname{TrP}$ e os parâmetros obtidos pela técnica de Estimulação magnética transcraniana (EMT) estão apresentados na Figura 29. Relações diretas foram observadas entre o TrP e a Amp evocada pelos estímulos magnéticos $(r=0,89 ; p=0,04)$ (Figura 29). 

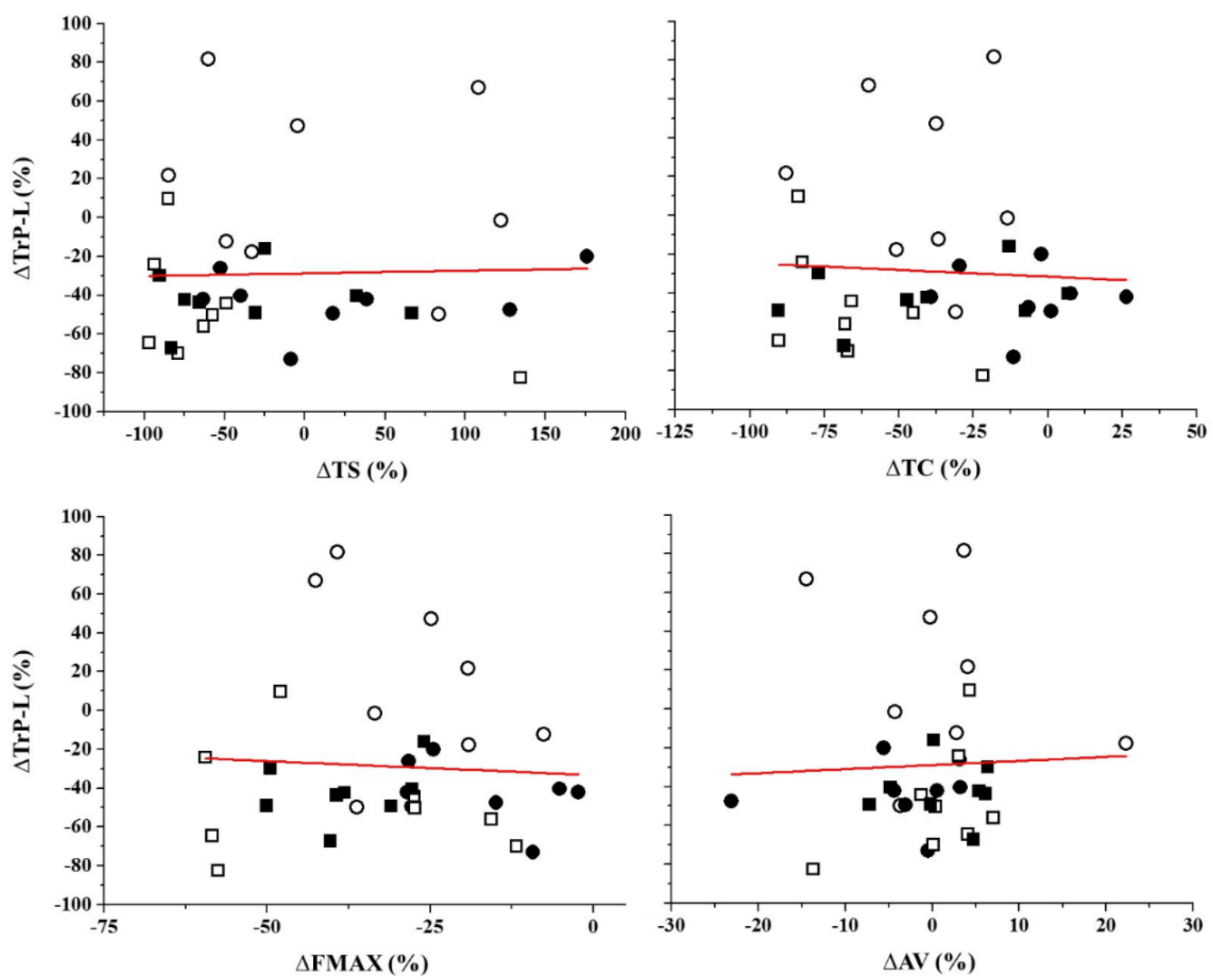

Figura 28. Relações entre as diferenças percentuais das concentrações de triptofano (TrP) e dos parâmetros obtidos pela técnica de Twitch Interpolation no E30Tlim (círculos) e no E40Tlim (quadrados), na situação em que o glicogênio estava depletado (B-Glic; símbolos abertos) e na situação após a recuperação deste substrato (R-Glic; símbolos fechados). Nenhuma das relações foi significativa ( $\mathrm{r}$ : entre - 0,55 e 0,$51 ; \mathrm{p}>0,15)$. TS: força evocada pela estimulação elétrica durante a contração máxima; TC: força evocada pela estimulação elétrica após a contração máxima; FMAX: força máxima observada durante a contração isométrica; AV: ativação voluntária. 

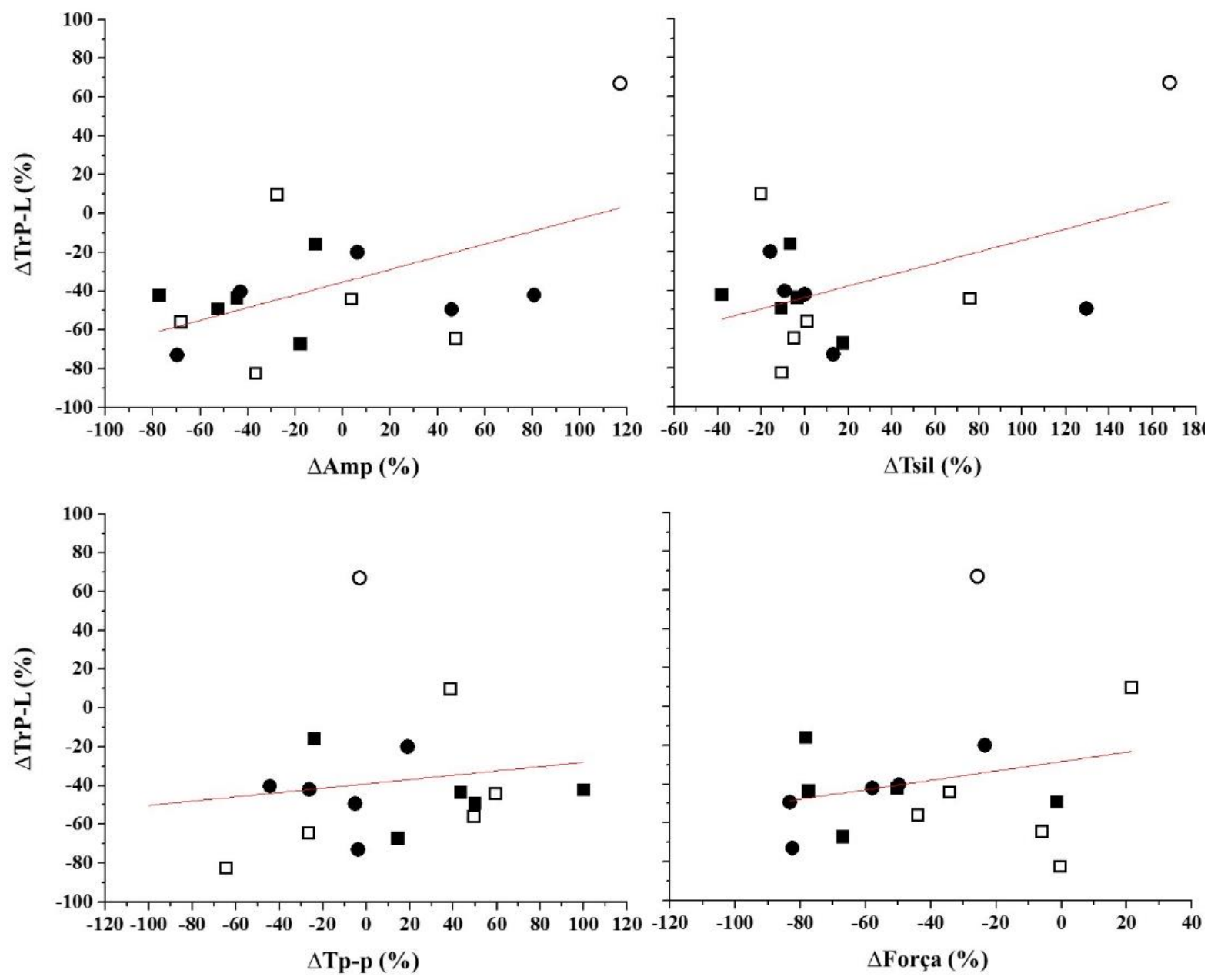

Figura 29. Relações entre as diferenças percentuais das concentrações de triptofano (TrP) e dos parâmetros obtidos pela técnica de Estimulação magnética transcraniana no E30Tlim (círculos) e no E40Tlim (quadrados), na situação em que o glicogênio estava depletado (B-Glic; símbolos abertos) e na situação após a recuperação deste substrato (R-Glic; símbolos fechados). Apenas a correlação entre as variações do TrP e da Amp foram significativas $(r=0,51 ; p=0,04)$. As outras análises não apresentaram relações significativas (r: entre 0,16 e 0,46; p > 0,07). Amp: Amplitude do sinal observado pela análise de EMG no momento do estímulo magnético; Tp-p: tempo entre o pico positivo e o pico negativo observados pela análise de EMG no momento do estímulo magnético; Tsil: tempo para que o sinal de EMG retorne ao comportamento normal durante uma contração submáxima após o estímulo magnético; Força: força evocada com o estímulo magnético. 


\section{DISCUSSÕES E CONSIDERAÇÕES}

\section{Efetividade do delineamento}

O principal objetivo do delineamento aplicado foi promover o fenômeno da supercompensação do glicogênio muscular. Considerando as observações do estudo anterior com esforços intermitentes de alta intensidade, neste delineamento buscamos uma depleção mais severa dos estoques de glicogênio muscular, associando esforços de elevada carga com uma dieta com baixas quantidades de carboidrato. Além disso, utilizamos o mesmo período de recuperação para o fenômeno de supercompensação observado por Bergström e Hultman [74] (i.e., três dias), o que foi associado a uma dieta com elevadas quantidades de carboidrato. A partir dos valores de glicogênio observados com a biópsia muscular, que demonstrou um aumento significativo das concentrações deste substrato para todos os participantes, podemos concluir que tivemos êxito em nosso propósito.

$\mathrm{Na}$ situação B-Glic a distribuição dos macronutrientes demonstrou um percentual de carboidratos, lipídeos e proteínas de $\sim 8,39$ e 53\%, respectivamente. Estudos prévios demonstraram que a indução de baixas quantidades de glicogênio muscular por meio da dieta pode levar a uma acidose metabólica, especialmente quando elevadas quantidades de proteína são aplicadas juntamente com quantidades inferiores a 10\% de carboidratos [75]. Com isso, a dieta aplicada no presente estudo pode ter contribuído para o comprometimento do desempenho na situação B-Glic. Entretanto, Maughan et al. [76] comenta em suas discussões alguns resultados não publicados sobre a administração de bicarbonato para anular os efeitos da acidose metabólica durante o exercício. Nestes estudos o tempo limite em exercício de alta intensidade manteve-se baixo na situação B-Glic, indicando que a acidose metabólica não explica a fadiga este tipo de esforço. 


\section{E30Tlim}

A diminuição do desempenho neste esforço foi evidenciada pelo trabalho, potência e Tlim inferiores na B-Glic. As respostas ventilatórias demonstram uma maior participação do metabolismo aeróbio na situação B-Glic, principalmente pelos valores superiores de $\mathrm{VO}_{2} \mathrm{e}$ inferiores de $\mathrm{VCO}_{2}$ e QR. Embora não tenham sido diferentes entre as situações, elevadas concentrações de lactato foram observadas e a glicemia diminuiu em relação ao repouso somente para R-Glic. Em conjunto estes resultados novamente indicam que os lipídeos foram o principal substrato utilizado na situação B-Glic, especialmente durante o primeiro esforço de 15 min e no Tlim, sem alterações significativas no fluxo da glicólise.

Os esforços realizados durante a B-Glic apresentaram um perfil de fadiga periférica, principalmente pela diminuição das variáveis obtidas de maneira involuntária como a TS e a $\mathrm{TP}$, de maneira significativamente diferente do que foi observado em R-Glic. Ao final do segundo esforço de 15 min, a Onda $M$ foi significativamente inferior na situação B-Glic em relação aos valores observados em R-Glic, demonstrando comprometimentos na capacidade do sarcolema reagir ao estímulo. Juntos estes resultados demonstram que tanto o processo de pontes cruzadas, como a capacidade do musculo em propagar o sinal, estão comprometidas a B-Glic [4]. Além disso, a RMS foi significativamente inferior ao longo de todos os esforços na situação B-Glic em relação a situação R-Glic, demonstrando a incapacidade de recrutamento muscular com a diminuição do glicogênio (i.e., fadiga central). Desse modo, o E30Tlim realizado com baixas concentrações de glicogênio apresentou ambas as origens da fadiga, periférica e central.

Diferentemente, os parâmetros da TI observados durante o E30Tlim demonstraram que a situação R-Glic preveniu a fadiga periférica relacionada aos mecanismos de ponte cruzada (i.e., sem alterações na TP e na TS) e de recrutamento e resposta muscular (i.e., manutenções ou 
aumentos significativos da RMS e Onda M). Entretanto, uma significativa diminuição da FP foi observada após o Tlim, o que pode estar relacionado a fadiga cortical. É plausível considerar esta hipótese pela interpretação em conjunto das significativas diminuições nas concentrações de $\operatorname{TrP}$, acompanhadas de significativas correlações entre as variações percentuais deste aminoácido e da força evocada durante os estímulos. Assim, o TrP na forma livre pode ter passado pela barreira hematoencefálica promovendo a formação de serotonina e, consequentemente, diminuindo a ação do motoneurônio (i.e., hipótese serotoninérgica) [25, 27, 76]. Considerando que o limiar de despolarização das fibras tipo II é maior que as do tipo I [77], é possível que a necessidade de utilização destas fibras de alto limiar por um longo período de tempo, acelere um quadro de fadiga central [78]. Desse modo, os valores significativamente superiores de RMS podem indicar que na situação R-Glic as fibras do tipo dois foram recrutadas por um longo período, o que não levou a distúrbios periféricos importantes, mas fadigou o sistema nervoso central.

\section{E40Tlim}

Novamente o desempenho foi superior na situação R-Glic em relação aos valores observados em B-Glic, o que ocorreu desde o primeiro esforço do E40Tlim. Diferentemente dos esforços investigados até aqui, nenhuma diferença entre as situações foi observada para as variáveis ventilatórias, demonstrando que a baixa intensidade do E40Tlim, independentemente da quantidade de glicogênio prévio, não estressou de maneira diferente o sistema respiratório. Entretanto, pela primeira vez em nossos estudos as concentrações de glicose foram significativamente inferiores na situação R-Glic após o Tlim. Além disso, embora diferenças em relação ao repouso tenham sido observadas para as duas situações, na situação B-Glic as concentrações de lactato foram significativamente inferiores em todos os esforços. 
Coletivamente estes resultados demonstram que a glicólise foi comprometida pela situação BGlic. Considerando a baixa intensidade proposta para este esforço, é possível que as concentrações de Acetil-CoA, oriundas da oxidação de lipídeos, elevam as concentrações de citrato, o que inibe a fosfofrutoquinase (PFK) [55]. O consequente acumulo de Glicose-6-P e o aumento da razão Glicose-6-P/Frutose-1,6-BiP inibem a enzima hexoquinase diminuindo eficiência da glicólise [56]. Todo esse mecanismo favorece a utilização de lipídeos durante a atividade física, preservando o conteúdo de glicogênio durante exercício moderado [55].

Os parâmetros obtidos pela técnica de TI, demonstram claramente que uma fadiga de ordem periférica ocorre de maneira antecipada na situação B-Glic, principalmente pelos valores inferiores de TP e TC observados nesta situação desde o primeiro esforço de 20 min. Além disso, os parâmetros de EMT não foram alterados ao longo dos esforços na situação B-Glic, demonstrando que a fadiga nesta situação possui caráter periférico. Considerando as alterações observadas na EMG (i.e., aumento da Onda M e da Razão), pode-se inferir que a fadiga periférica observada na situação B-Glic pode estar relacionada ao fornecimento da energia para contração muscular. Neste sentido, levando-se em consideração o acumulo de lactato observado na R-Glic, a intensidade proposta para este esforço demanda uma utilização da glicólise, a qual estava inibida na situação B-Glic, provavelmente por efeitos alostéricos (e.g., glicogênio muscular em níveis críticos, aumento do citrato, inibição da hexoquiase e da PFK) [55, 64]. Assim, uma possível explicação para a fadiga periférica observada no E40Tlim na situação BGlic é que a utilização da $\beta$-oxidação não possui potência suficiente para manter as demandas deste esforço. É importante salientar que, embora na corrida e no ciclismo o Tlim em um esforço a $70 \%$ da $\mathrm{iVO}_{2 \text { PICO }}$ seja $>40$ min $[6,40]$, no modelo de extensão dinâmica de joelhos esta intensidade não foi bem tolerada (Documento auxiliar IV - Padronização da depleção.), demonstrado a elevada demanda energética desta intensidade neste modelo de exercício. 
Oriundos da glicólise ativada, além do lactato outros produtos começam a acumular no meio intramuscular - como o $\mathrm{Pi}, \mathrm{H}^{+}$, ADP, AMP e consequentemente, a queda do $\mathrm{pH}-$ causando a fadiga periférica observada na R-Glic a partir do segundo esforço [2, 4]. Além disso, o tempo entre os picos dos estímulos magnéticos diminuiu significativamente após o segundo esforço de 20 min na situação R-Glic. A Amp e a força evocada pelos estímulos após o Tlim também diminuíram nesta situação. Embora estes resultados indiquem um quadro de fadiga supra espinhal, existem duas explicações plausíveis para estas observações. A primeira está relacionada a manifestação do modelo de governador central [45-47], principalmente pelo tempo elevado de distúrbio metabólico induzido pelo E40Tlim. A segunda explicação diz respeito às possíveis influências da fadiga periférica sobre os parâmetros da EMT. Diferentemente dos resultados observados no E30Tlim, no presente caso a fadiga periférica foi observada mesmo na situação R-Glic, impossibilitando a afirmação de que a diminuição das respostas musculares aos estímulos magnéticos está relacionada apenas a um comprometimento do sistema nervoso central. Considerando a inconsistência dos dados, onde foram apresentadas respostas positivas (i.e., diminuição do tempo entre os picos) e negativas ao exercício (i.e., diminuição da Amp e da Força), acreditamos que estas variações observadas na situação R-Glic não caracterizam um quadro de fadiga central, mas sim confirmam a fadiga periférica observada com a TI.

As concentrações plasmáticas de TrP foram maiores no repouso da situação R-Glic, o que discorda de vários trabalhos na literatura $[25,27,28,76]$, provavelmente por se tratar das concentrações totais deste metabólito. Estes resultados, provavelmente, indicam que a porção livre de TrP pode ter passado a barreira hematoencefálica no repouso da situação B-Glic, diminuindo as concentrações totais. Independentemente das concentrações em repouso, foram observadas significativas diminuições nas concentrações plasmáticas de $\operatorname{TrP}$, indicando um 
consumo deste aminoácido pelo sistema nervoso central. De fato, significativas correlações foram observadas entre as concentrações de TrP e a AV observada após o segundo esforço da situação de B-Glic, demonstrando que este aminoácido pode estar relacionado com parâmetros de fadiga central, ao menos quando as quantidades de glicogênio estão em nível crítico. Além disso, as concentrações de $\operatorname{TrP}$ foram significativamente correlacionadas com o período de silêncio observado após o segundo esforço da situação B-Glic (i.e., TrP é relacionado com os potenciais inibitórios intracorticais [47]). Por fim, significativas correlações foram observadas na situação R-Glic entre o TrP e o tempo entre os picos do estímulo, o que demonstra um maior tempo de recuperação após o estímulo. Considerando estes resultados, embora as alterações centrais não tenham sido consistentes e/ou significativas, as concentrações de TrP parecem estar relacionadas com a incapacidade do sistema nervoso central contrair o músculo.

\section{Relações do $\Delta T r P$ com todos os parâmetros de fadiga independentemente da situação}

Quando desconsideramos as possíveis diferenças entre as situações, a variação percentual do TrP foi significativamente correlacionada com a variação percentual da Amp. Este resultado pode demonstrar que o TrP está relacionado com a capacidade do sistema nervoso central enviar o estímulo até o músculo, independentemente da quantidade de glicogênio muscular.

\section{Limitações}

Embora nosso delineamento tenha sido efetivo para a depleção e posterior supercompensação do glicogênio muscular, o período de recuperação entre o exercício prévio e o E30Tlim não foi o mesmo entre as situações, o que pode caracterizar uma limitação do presente estudo. Entretanto, como experenciamos em todos os procedimentos do nosso laboratório, a realização de extensões dinâmicas de joelho não causa dor tardia nos 
participantes, o que indiretamente e superficialmente pode indicar que baixos níveis de microlesão neste exercício. Outra limitação do presente estudo foi a baixa efetividade da EMT, o que diminuiu o número de participantes para estas análises. De fato, todas as discussões realizadas acima sobre os resultados da EMT devem ser realizadas com cautela. A opção de não utilizar um cateter para a obtenção das amostras sanguíneas implicou na diminuição das determinações de TrP ao longo dos esforços, o que também pode representar uma limitação do presente estudo. 


\section{Capítulo - 5 Considerações e conclusões da tese}

Em resposta à pergunta central do presente projeto de pesquisa que foi "Qual é a origem da fadiga (central ou periférica) em esforços realizados com baixas quantidades de glicogênio muscular?", pode-se concluir que a origem da fadiga em esforços com diferentes quantidades de glicogênio é influenciada pela intensidade do exercício realizado. Especificamente a fadiga em esforços com B-Glic tem origem periférica em esforços intermitentes de alta intensidade e nos esforços de moderada duração apresenta um caráter misto (E30Tlim) ou somente periférico (E40Tlim). A origem central da fadiga emerge no domínio pesado, quando o esforço é realizado na situação R-Glic.

Desse modo, a situação B-Glic compromete o desempenho, o que foi acompanhado por um quadro de fadiga com origem periférica em todas as intensidades. Entretanto, refutamos a hipótese de que as baixas quantidades de glicogênio muscular poderiam levar a alterações sistêmicas e, consequentemente, diminuir a ativação muscular pelo sistema nervoso. De fato, este quadro de fadiga central somente ocorreu na situação R-Glic, o que demonstra que a fadiga central pode estar relacionada não somente ao volume do exercício, mas também à demanda imposta por este esforço. A Figura 30 resume os principais resultados da presente tese. 


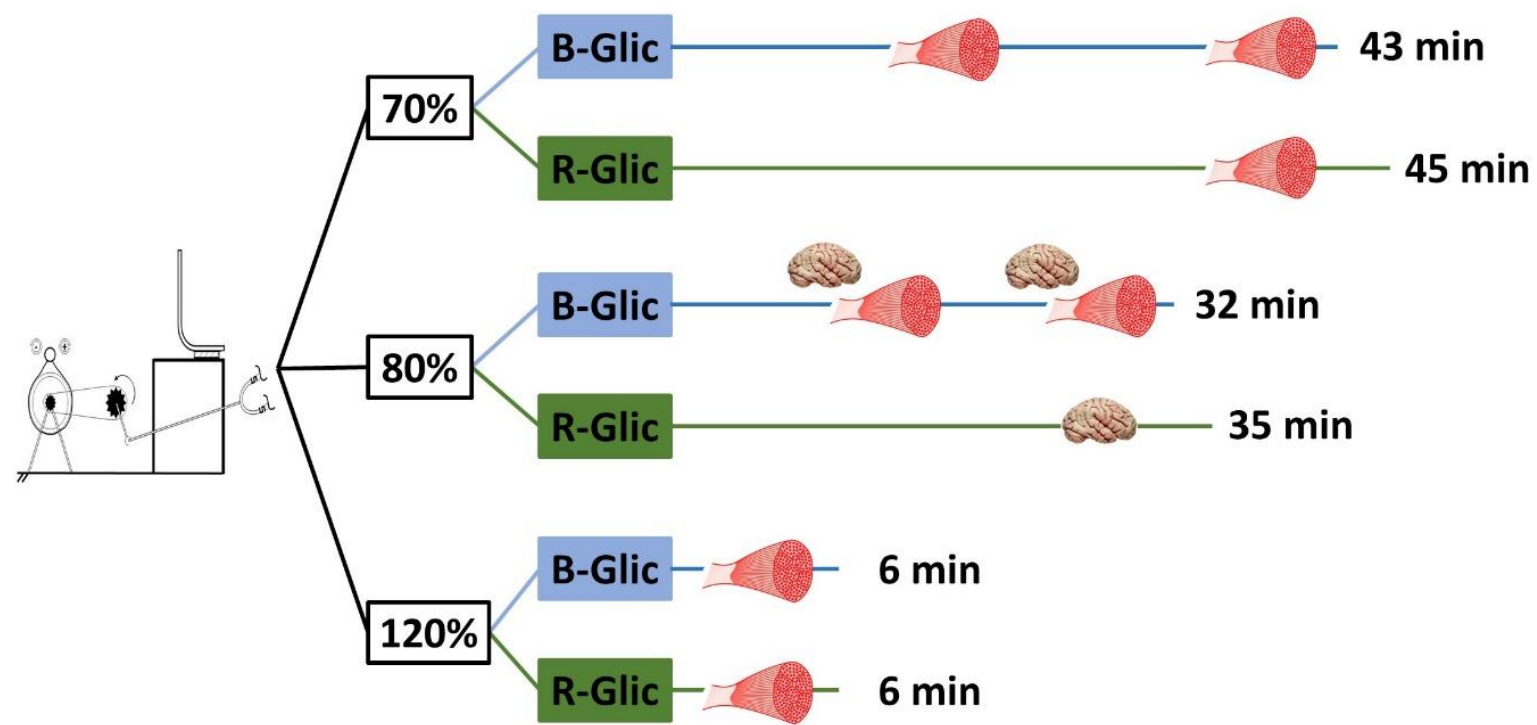

Figura 30. Principais resultados observados na presente tese durante os esforços realizados com baixas quantidades de glicogênio muscular (B-Glic) e quando este substrato foi recuperado (R-Glic) com o aumento do volume e da intensidade de exercício. Os músculos representam os momentos em que a fadiga periférica ocorreu e os cérebros representam os indícios de fadiga central. No esforço de 40 min realizado a $70 \%$ do $\mathrm{VO}_{2 \mathrm{PICO}}$ seguido por um esforço até a exaustão, a fadiga teve caráter periférico, com valores mais precoces na situação B-Glic. No esforço de 30 min realizado a $80 \%$ do $\mathrm{VO}_{2 \mathrm{PICO}}$ um esforço até a exaustão, a fadiga teve caráter misto na situação B-Glic, mas somente central quando o esforço foi realizado em R-Glic. Quando o esforço foi realizado de maneira intermitente (i.e., 6 x 1 min, com intervalo de 3 min) e em alta intensidade ( $120 \%$ do $\mathrm{VO}_{2 \mathrm{PICO}}$ ), a fadiga foi de caráter periférico em ambas as situações. Ainda neste modelo de exercício, embora tenham sido observados valores mais incisivos de fadiga periférica na situação R-Glic, o desempenho foi claramente comprometido na situação B-Glic. 


\section{Documento auXILIAR}

\section{I - REVISÃO DA LITERATURA (voltar ao documento principal)}

\section{Funções e conceitos gerais sobre o glicogênio}

O glicogênio é um complexo polímero formado por glicose encontrado principalmente no músculo esquelético e no fígado [7, 17, 21, 54]. Embora seja estocado em concentrações mais elevadas no fígado ( 20\% ou $100 \mathrm{~g}$ ), o que permite a manutenção da glicemia, as maiores quantidades absolutas deste substrato são encontradas na musculatura esquelética ( 400 g) [79]. Considerando a relativa facilidade com que as amostras de tecido podem ser obtidas, principalmente após a padronização da técnica de biópsia pela agulha de Bergström $[80,81]$, existe uma extensa literatura relacionada ao glicogênio muscular. De fato, estudos relativamente recentes têm demonstrado que a função do glicogênio muscular vai além de ser uma rápida fonte de energia, sendo responsável por uma série de sinalizações locais e sistêmicas, que alteram radicalmente o ambiente fisiológico do organismo [17, 21].

Os polímeros de glicogênio são uma estrutura ramificada formadas basicamente por moléculas de glicose organizadas em torno da proteína glicogenina. As moléculas de glicose são organizadas em até 12 camadas, aumentando a superfície da molécula de glicogênio e permitindo sua rápida degradação. Estima-se que um polímero de glicogênio pode armazenar até 55.000 moléculas de glicose distribuídas em $8.000 \mathrm{~nm}^{3}$ [82]. Os resíduos de glicose são acoplados em até 12 moléculas que se ligam por meio ligações covalentes tipo $\alpha(1 \rightarrow 4)$. Por sua vez as ramificações são ligadas as outras cadeias de resíduos de glicose por meio de ligações $\alpha(1 \rightarrow 6)[83]$. 
No músculo o glicogênio é armazenado em três sítios, o que parece estar relacionado a sua função [7, 84]. Desse modo, o glicogênio pode ser armazenado entre as miofibrilas, próximo as mitocôndrias e ao reticulo sarcoplasmático ( $75 \%$ do total), entre os filamentos contrateis $(\sim 5-15 \%$ do total $)$ e logo abaixo do sarcolema ( $5-15 \%$ do total). Além disso, embora exista alguma discussão [21], o glicogênio parece estar mais concentrado em fibras do tipo II em relação as fibras oxidativas do tipo I [85, 86]. Estas características de distribuição do glicogênio podem ser significativamente alteradas por fatores como nível de treinamento e estado tanto de fadiga como de disponibilidade de carboidratos [17, 21, 54].

Considerando estas informações, pode-se perceber que o glicogênio possui é uma molécula bastante complexa, mas ao mesmo tempo muito dinâmica em suas funcionalidades fisiológicas. As próximas sessões desta revisão irão destacar ainda mais estes aspectos, discutindo i) a formação e degradação do glicogênio, ii) como a depleção desta molécula ocorre em diferentes intensidades de exercício e iii) como o glicogênio pode estar relacionado à fadiga.

\section{Glicogênio muscular: síntese e depleção}

A hiperemia causada pelo exercício juntamente com o aumento do fluxo sanguíneo aumenta a oferta de glicose e a permeabilidade dos capilares para o músculo em exercício [87]. Desse modo, as moléculas de glicose da corrente sanguínea podem ser transportadas pelos poros endoteliais para o interstício e, posteriormente, para o meio intramuscular por difusão facilitada, o que é mediado pela translocação dos transportadores transmembrana de glicose (i.e., principalmente a isoforma GLUT4). Após sua passagem pelo sarcolema, a glicose é rapidamente fosforilada em Glicose-6-Fosfato (G6F), pela ação da enzima Hexoquinase [83]. Este processo habilita sua utilização para obtenção de energia ou para seu armazenamento em forma de glicogênio (i.e., glicogênese). 
A glicogênese inicia pela translocação de um grupo fosforil da G6F, formando Glicose1-Fosfato, ação catalisada pela enzima Fosfoglicomutase. Esta translocação ativa a enzima UDP glicose-pirofosforilase, que utiliza um grupamento UTP para formar a UDP-Glicose. A partir deste composto a enzima Glicogênio Sintase (GS) pode acoplar os resíduos de glicose em uma ramificação do glicogênio, em forma de $\alpha(1 \rightarrow 4)$-Glicose, inicialmente acoplada a proteína Glicogenina. Em torno de oito resíduos de glicose são acoplados em uma ramificação de glicogênio por meio de ligações $\alpha(1 \rightarrow 4)$, a partir desse ponto outra ramificação deve ser formada, adicionando um resíduo de glicose por meio de ligação $\alpha(1 \rightarrow 6)$. Esta última ação é catalisada pela enzima Ramificadora de Glicogênio (amilo- $\alpha(1: 4) \rightarrow \alpha(1: 6)$ transglicosilase), o que permite que mais uma ramificação seja iniciada a partir do resíduo $\alpha(1 \rightarrow 6)$-Glicose [83]. A Figura 31 representa um esquema da glicogênese.

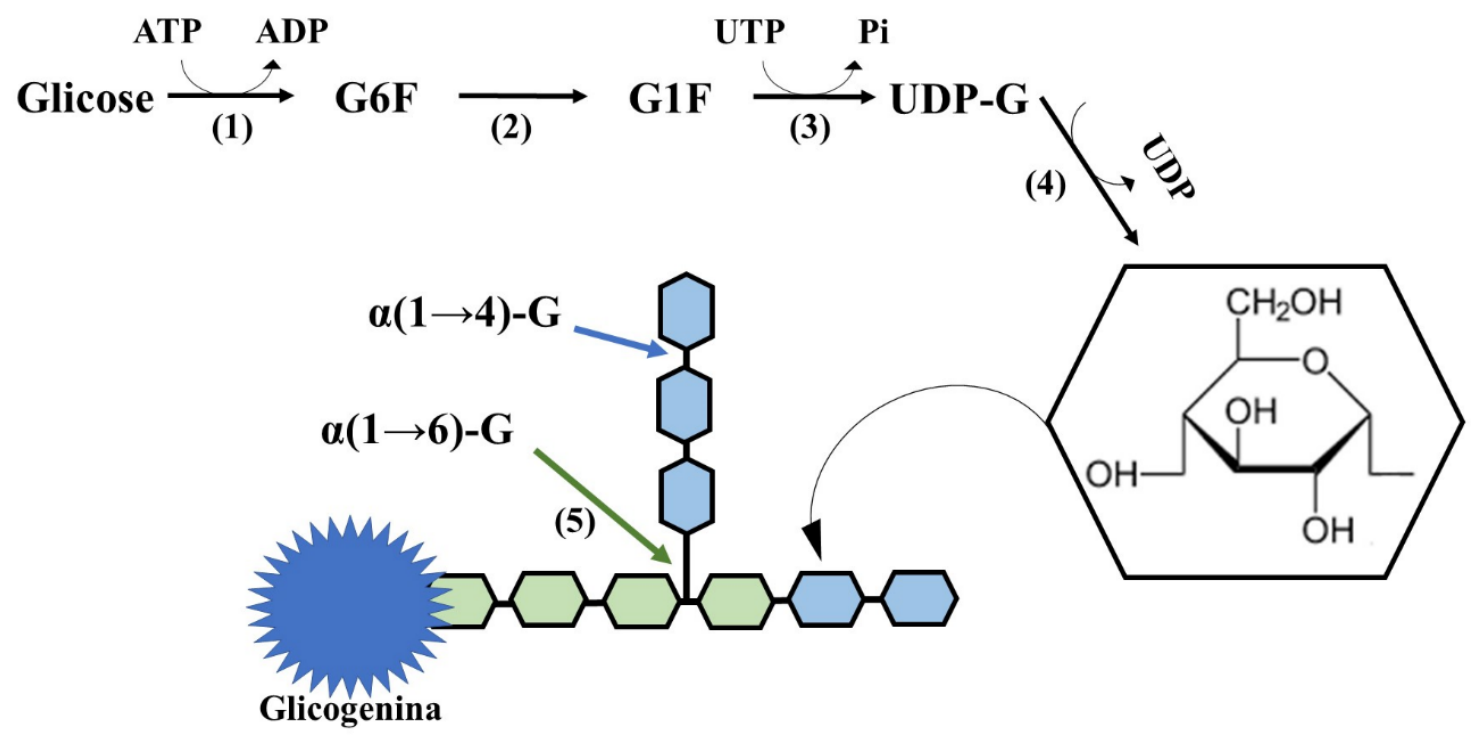

Figura 31. Esquema ilustrativo da glicogênese. As enzimas foram identificadas por números: 1: Hexoquinase; 2: Fosfoglicomutase; 3: glicose-pirofosforilase; 4: Glicogênio sintase; 5: Ramificadora de Glicogênio. G6F: Glicose-6-Fosfato; G1F: Glicose-1-fosfato; Pi: Fosfato inorgânico; UDP-G, Glicose ligada ao UDP. (Baseado em [64]) 
Embora várias enzimas estejam envolvidas na glicogênese, a GS é considerada como a principal controladora do fluxo desta cascata de reações $[88,89]$. A GS pode ser ativada pela desfosforilação de nove sítios, o que indica a grande complexidade envolvida na formação do glicogênio. Estas reações de ativação são reguladas por ativadores alostéricos, sendo a G6F a molécula com maior afinidade com a GS [64]. Além disso, outros estímulos fisiológicos coma adrenalina, insulina, a contração muscular e a própria quantidade de glicogênio muscular, podem alterar o meio muscular e levar ao aumento de outros metabólitos que favorecem, ou desfavorecem a ativação da GS [79]. De fato, os principais inibidores da GS são produtos oriundos da contração muscular e/ou da ativação da Glicogênio Fosforilase (GF), enzima de ação antagônica a GS [64, 90]. Além destas, alguns complexos proteicos envolvidos com a regulação do ciclo circadiano (CKI e CKII), com fatores de stress musculares (p38 $\beta$ ) e com a fosforilação de aminoácidos como as serinas (GSK3), formadoras da estrutura da GS [90]. A Figura 32 esquematiza a GS, seus sítios de fosforilação, e os compostos que podem atuar em cada sítio favorecendo sua inibição.

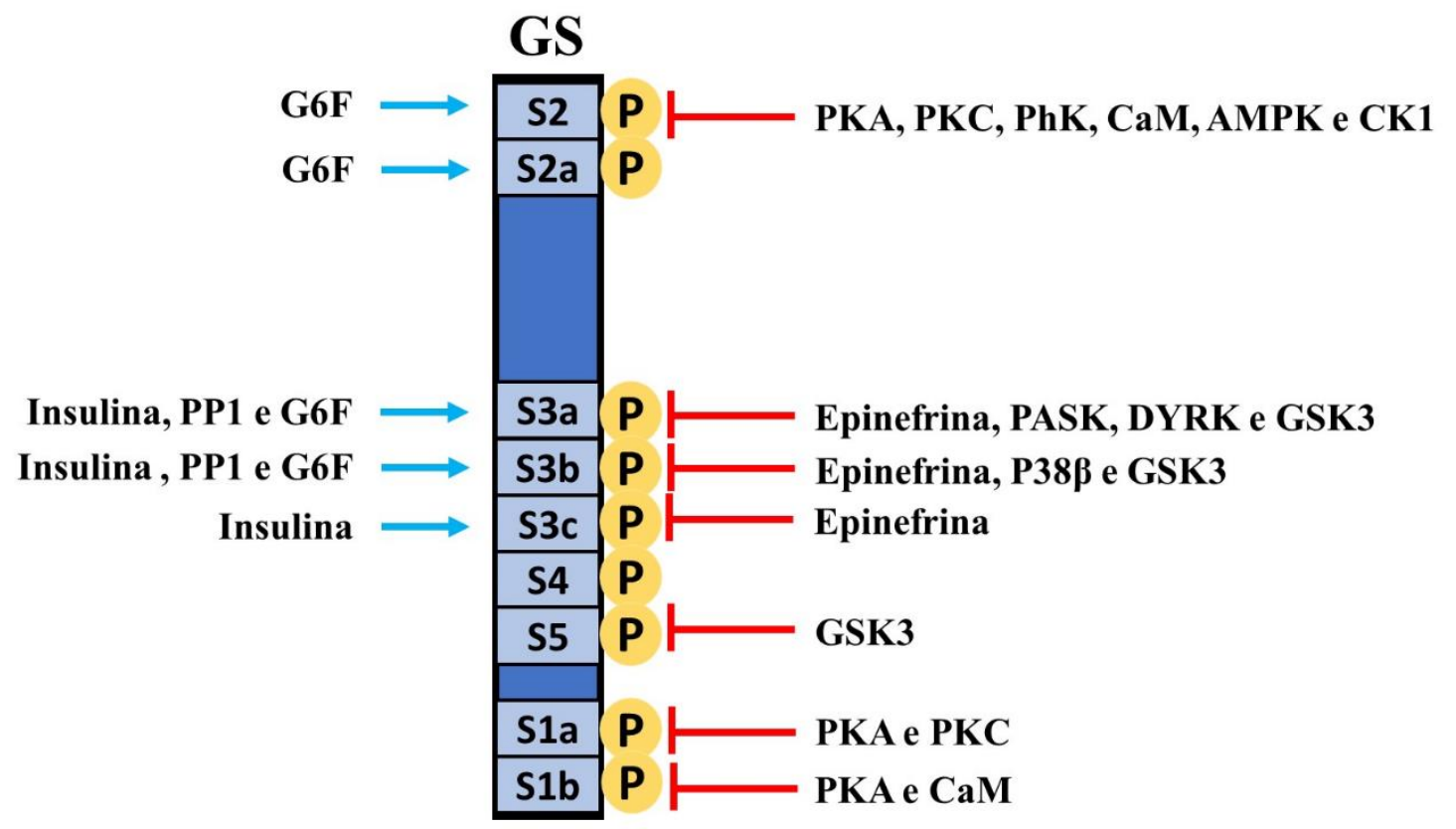

Figura 32. Fatores de ativação (flechas azuis) e de inibição (símbolos vermelhos) para a 
glicogênio sintase (GS) no musculo esquelético. (Fonte figura: Próprio autor; Informações principais: $[64,91])$

É evidente que a quantidade de fatores inibitórios à GS favorece sua fosforilação. Entretanto, estudos in vitro demonstram que quando a GS é mantida em meio saturado de G6F, sua atividade é mantida independentemente do inibidor presente, demonstrando que este intermediário da glicólise possui grande afinidade com esta enzima [64]. Este aspecto é de extrema importância, considerando principalmente que a translocação do GLUT4 continua após o exercício [64], assim como o maior fluxo sanguíneo [92], o consumo de glicose pelo músculo continua aumentado após o esforço, proporcionando um acumulo de G6F e, consequentemente, uma grande atividade da GS.

Além disso, como demonstrado pioneiramente por Bergström e Hultman [74], outras respostas observadas após o exercício potencializam a glicogênese, aumentando os níveis de glicogênio acima dos evidenciados antes do exercício, fenômeno reconhecido como "supercompensação do glicogênio". Dentre as respostas potencializadoras deste fenômeno, pode-se destacar a elevada expressão da enzima Hexoquinase que, juntamente com a supressão da enzima piruvato desidrogenase, aumenta a quantidade de G6F e diminui o fluxo da glicólise $[64,93]$. Estas respostas potencializam a fosforilação da GS por diferentes fatores (e.g., AMPK, PKA e GSK3, [90]) e aumentam a afinidade desta enzima pelo seu ativador alostérico (i.e., G6F) e pelo seu substrato a UDP-Glicose. Assim, principalmente os sítios 2, 2a, 3a e 3b, se mantem desfosforilados, potencializando a GS por vários dias ( 5 dias) [64], mesmo após os estoques de glicogênio retornarem ao estado basal, o que explica o fenômeno da supercompensação.

Teoricamente, buscamos o fenômeno da supercompensação durante o treinamento de 
várias modalidades, principalmente pela importância do glicogênio como substrato energético. De fato, quando o exercício é realizado com elevadas concentrações de glicogênio, este substrato ganha preferência para a manutenção do esforço, acarretando novamente sua depleção [21, 56]. Além disso, a depleção do glicogênio apresenta uma seletividade em relação ao tipo de fibra, onde em esforços de longa duração (> 40 min) a depleção é evidente nas fibras do tipo I e nos esforços de alta intensidade realizados de maneira intermitente as fibras do tipo II são depletadas $[10,94]$.

A Glicogênio fosforilase (GF) é a principal enzima responsável pelo processo de glicogenólise [95], que remove um resíduo de glicose do glicogênio quebrando as ligações $\alpha(1 \rightarrow 4)$ as custas de um fosfato inorgânico $(\mathrm{Pi})$. Dessa forma a Glicose-1-Fosfato é liberada ativado a enzima Fosfoglicomutase, que converte esta molécula em Glicose-1,6-difosfato. Novamente um fosfato é transferido para a Fosfoglicomutase, gerando a G6F que pode ser utilizada pela glicólise. É importante destacar que a GF não remove os resíduos de glicose ligados por $\alpha(1 \rightarrow 6)$, sessando sua ação nos quatro últimos resíduos de glicose de uma ramificação. A partir disso, é necessária a ação da enzima Desramificadora de glicogênio, que possui duas subunidades conhecidas como Glicotransferase e Glicosidase. A Glicotransferase acopla três resíduos de glicose em uma ramificação próxima, liberando o último resíduo de glicose para a ação da Glicosidase, que quebra a ligação $\alpha(1 \rightarrow 6)$ e encerra a utilização daquela ramificação [96].

A GF apresenta-se em duas isoformas, sendo uma inativa (GFi) e outra muito ativa (GFa) [97]. Desse modo, o primeiro passo para a glicogenólise é a ativação da GF, que pode ser realizada pela ação da Epinefrina e da Acetilcolina. A Epinefrina é recebida pelos receptores $\alpha$ adrenérgicos ativando a Adenilato Ciclase e, consequentemente, promovendo a formação de AMP cíclico (cAMP). Na presença de cAMP a proteína Quinase A (PKA) é ativada, induzindo 
também a ativação da Fosforilase Quinase (PhK) que por sua vez altera o estado da GFi para GFa. Diferentemente, a Acetilcolina inicia a despolarização do sarcolema levando a liberação do cálcio $\left(\mathrm{Ca}^{++}\right)$pelo retículo sarcoplasmático. $\mathrm{O} \mathrm{Ca}^{++}$muda a conformação da calmodulina (CaM) e ativa a PhK, promovendo a alteração de estado da GFi para GFa [98]. Desse modo, a contração muscular é o principal agente para ativação da GF e, consequentemente, promove a liberação/ativação de vários fatores de inibição da GS (e.g., PKA, PhK e CaM) [99]. A Figura 33, esquematiza as vias de ativação da GF.

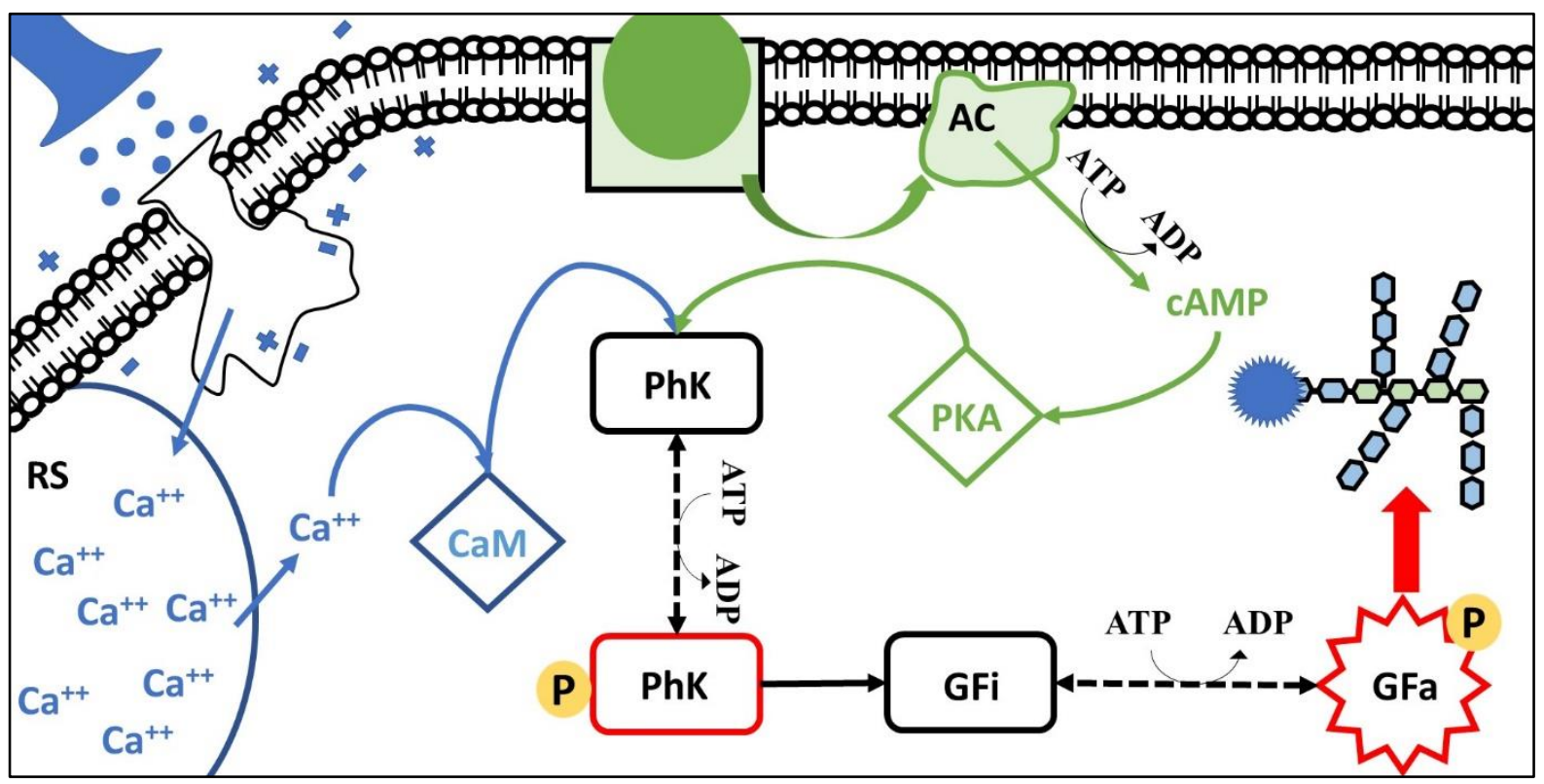

Figura 33. Vias de ativação da enzima glicogênio fosforilase (GF). As relações em azul representam a via que é desencadeada pela Acetilcolina e as em verde representam a via de ativação desencadeada pela Epinefrina. CaM: Calmodulina; PhK: Fosforilase quinase; GFi: forma inativa da enzima glicogênio sintase; GFa: forma ativa da enzima glicogênio sintase; AC: Adenilato ciclase; PKA: Proteína quinase A. (Fonte: Próprio autor)

Além destas vias, com o aumento da demanda energética causada pela atividade física, metabólitos como o Pi, ADP e AMP podem acumular no meio intramuscular, representando ativadores alostéricos da GF [100]. De modo antagônico, a ação da insulina promove a inibição 
da GF, principalmente pela translocação do GLUT-4, com consequente formação de G6F pela fosforilação da glicose mediada pela Hexoquinase [64, 99]. Neste caso, teremos uma maior desfosforilação da GS, propiciando a formação de glicogênio.

\section{Influência da quantidade de glicogênio sobre o desempenho}

Estudos sobre a importância da disponibilidade de carboidratos têm sido desenvolvidos desde 1920 [101]. Desde estes achados pioneiros, uma série de estudos tem demonstrado a importância da disponibilidade de carboidratos para o desempenho, o que parece ser dependente da intensidade de exercício realizada. Desse modo, nesta sessão da revisão de literatura, serão apresentados os trabalhos encontrados que utilizaram a estratégia de depleção do glicogênio (i.e., esforços realizados com baixas quantidades de glicogênio; B-Glic) seguida de um período de supercompensação deste substrato (i.e., recuperação do glicogênio; R-Glic).

A taxa de utilização, considerada como a quantidade de glicogênio utilizada por unidade de tempo, aumenta concomitantemente com a intensidade do exercício [40, 54]. Entretanto, a duração do esforço realizado parece não influenciar as quantidades de glicogênio muscular observadas na exaustão [40, 54]. Além disso, a exaustão parece ocorrer em um quadro normoglicêmico, o que indica que a disponibilidade de glicose não está comprometida [102]. Estes achados parecem indicar que o glicogênio tem um "limiar" para que seja utilizado durante o exercício, o que foi recentemente proposto a partir de estudos utilizando sessões de treinamento com B-Glic [103].

Vários estudos investigaram a influência da quantidade de glicogênio sobre o desempenho em esforços de alta intensidade (i.e., < 20 min de duração). O primeiro estudo encontrado nesta intensidade foi realizado por Hermanssen et al. [16]. Estes autores aplicaram diferentes dietas para modular a disponibilidade de carboidratos (baixa: $\sim 0,3 \mathrm{~g} \cdot \mathrm{Kg}^{-1} \cdot \mathrm{dia}^{-1}$; alta: 
$\sim 7$ g. $\mathrm{Kg}^{-1} \cdot \mathrm{dia}^{-1}$ ) antes de um exercício realizado até a exaustão (Tlim) na intensidade correspondente ao $\mathrm{VO}_{2 \mathrm{MAx}}$. Estes autores observaram que o grupo com alta disponibilidade de carboidratos apresentou desempenho superior ao grupo com baixa disponibilidade. Entretanto, estes autores não mensuraram as quantidades de glicogênio muscular e nenhum esforço de depleção foi realizado previamente. Esta limitação experimental também foi apresentada por outros estudos similares, que observaram desempenhos superiores em dietas com alta disponibilidade de carboidratos, mas não determinaram as quantidades de glicogênio muscular $[76,104,105]$

Esta questão foi implementada somente 24 anos depois no estudo de Lamb et al. [106], que realizaram dois dias de exercício seguidos de três dias de supercompensação do glicogênio (B-Glic: 4,5 g. $\mathrm{Kg}^{-1} \cdot \mathrm{dia}^{-1}$; R-Glic: $7,5 \mathrm{~g} \cdot \mathrm{Kg}^{-1} \cdot \mathrm{dia}^{-1}$ ). O exercício de interesse foi um esforço até a exaustão com intensidade de $125 \%$ do $\mathrm{VO}_{2 \mathrm{MAX}}$. Os autores não observaram diferenças significativas no desempenho entre as situações. Além disso, a depeleção do glicogênio após o esforço foi semelhante entre as duas situações ( 7\%). Entretanto, embora uma diferença de $40 \%$ tenha sido evidenciada no glicogênio em repouso, a situação R-Glic falhou em produzir o fenômeno da supercompensação, pois os valores de glicogênio foram inferiores aos observados com a dieta normal. Diferentemente, Tarnopolsky et al. [107] demonstraram que uma dieta com elevadas quantidades de carboidrato $\left(\sim 8 \mathrm{~g} \cdot \mathrm{Kg}^{-1} \cdot \mathrm{dia}^{-1}\right)$ induziu um aumento no desempenho até a exaustão a $85 \%$ do $\mathrm{VO}_{2 \mathrm{MAX}}$ em relação a dieta normal $\left(6,8 \mathrm{~g} \cdot \mathrm{Kg}^{-1} \cdot \mathrm{dia}^{-1}\right)$, apenas para o grupo que apresentou diferenças nas quantidades de glicogênio em repouso ( 29\% superior com a dieta de elevadas quantidades de carboidrato). Uma diminuição significativa do glicogênio muscular foi observada após o esforço ( 75\% de diminuição), sem diferença entre as situações $(\sim 3 \%)$.

Balsom et al. [57] associaram uma dieta com baixas quantidades de carboidrato e 
exercícios para a depleção, o que foi efetivo para a depleção do glicogênio muscular e posterior supercompensação ( 120\% a mais de glicogênio em R-Glic). Estes autores observaram desempenhos significativamente superiores na situação R-Glic em esforços intermitentes de alta intensidade (i.e., $15 \times 6$ s com intensidade de $200 \%$ do $\mathrm{VO}_{2 \mathrm{MAX}}$, separados por $30 \mathrm{~s}$ de recuperação passiva). Além disso, a taxa de utilização do glicogênio foi $13 \%$ maior na situação R-Glic.

Em conjunto estes resultados demonstram que o desempenho em esforços de alta intensidade parece ser influenciado pela quantidade prévia de glicogênio muscular. Entretanto, podemos notar alguns pontos interessantes nestes estudos, como i) ainda não foram realizados experimentos separando as concentrações de glicogênio em B-Glic e R-Glic, em intensidades acima do $\mathrm{VO}_{2 \mathrm{MAX}}$, ii) os esforços realizados próximo ao $\mathrm{VO}_{2 \mathrm{MAX}}$ não foram aplicados de maneira intermitente, iii) não foram observados estudos controlados por placebo e esquema duplo-cego; iv) embora a influência das quantidades de glicogênio pareça influenciar no desempenho em esforços de alta intensidade, a origem da fadiga ainda não foi demonstrada. Buscamos implementar todos estes aspectos no estudo redigido no Capítulo 3 do documento principal.

Em relação a esforços de moderada duração (i.e., entre 20 e 90 min), os estudos têm demonstrado resultados contraditórios. Hawley et al. [108] não observaram diferenças significativas no desempenho em 60 min de ciclismo, aplicando dietas controle $\left(\sim 6 \mathrm{~g} \cdot \mathrm{Kg}^{-1} \cdot \mathrm{dia}^{-}\right.$ ${ }^{1}$ ) ou com baixo conteúdo de glicogênio $\left(\sim 9 \mathrm{~g} \cdot \mathrm{Kg}^{-1} \cdot \mathrm{dia}^{-1}\right)$. Estes resultados foram muito parecidos com os observados por Madsen et. al., [109] que utilizaram o tempo até a exaustão em $\sim 75 \%$ do $\mathrm{VO}_{2 \mathrm{MAX}}$ após modular a dieta do grupo experimental com 3 dias de baixo consumo, seguidos de três dias de alto consumo de carboidratos. Entretanto, Alghannam et al. [68] aplicaram dois esforços exaustivos a $70 \%$ do $\mathrm{VO}_{2 \mathrm{MAX}}$, separados por $4 \mathrm{~h}$. Durante a 
recuperação, os participantes receberam ou não uma solução contendo altas $\left(1,2 \mathrm{~g} \cdot \mathrm{kg}^{-1} \cdot \mathrm{h}^{-1}\right)$ ou baixas $\left(0,3 \mathrm{~g} \cdot \mathrm{kg}^{-1} \cdot \mathrm{h}^{-1}\right)$ quantidades de carboidrato. Estes autores observaram um desempenho 40\% superior quando o glicogênio foi recuperado ( 40\% de diferença para o glicogênio).

De fato, as evidências mais contundentes da influência do glicogênio muscular sobre o desempenho foram demonstradas em esforços com duração > 90 min. Ahlborg et. al., [110] aplicaram manipulações bastante agressivas na dieta administrando baixas $\left(\sim 0,1 \mathrm{~g} \cdot \mathrm{Kg}^{-1} \cdot \mathrm{dia}^{-1}\right)$ ou muito altas $\left(>9,5 \mathrm{~g} \cdot \mathrm{Kg}^{-1} \cdot \mathrm{dia}^{-1}\right)$ quantidades de carboidratos. Este delineamento induziu a diferenças marcantes no glicogênio muscular de repouso ( 334\% > com altas quantidades), o que foi associado com um desempenho $66 \%$ superior em um Tlim em $85 \%$ do $\mathrm{VO}_{2 \mathrm{MAx}}$. Resultados semelhantes foram observados por Bosch et al., [111] que induziram diferenças de $148 \%$ no glicogênio de repouso na situação em que foi administrado elevadas quantidades de carboidrato em relação a uma dieta com baixas quantidades desse macronutriente. Este delineamento induziu um aumento de $39 \%$ no desempenho em um Tlim na intensidade de $70 \%$ do $\mathrm{VO}_{2 \mathrm{MAX}}$. Estes resultados levaram vários estudiosos a propor diferentes estratégias para que o glicogênio seja preservado durante o esforço de longa duração, destacando-se a ingestão de carboidratos durante o esforço [112].

Considerando estes resultados sobre esforços de moderada e longa duração, parece que a influência do o glicogênio muscular em esforços maiores que 90min está bem estabelecida. Entretanto, esforços de moderada duração (i.e., 20 - 90 min) ainda possuem resultados inconclusivos. Além disso, o estudo de Alghannam et al. [68] demonstra um aspecto importante pouco explorado na literatura, mostrando a lacuna sobre a influência da disponibilidade de glicogênio sobre o desempenho até a exaustão realizado após esforços de moderada duração. Este conhecimento pode ser de grande valia para modalidades onde o final de provas relativamente longas deve ser realizado em alta intensidade (e.g., ciclistas sprinters). Os 
delineamentos observados raramente induziram comparações entre B-Glic e R-Glic associando dietas e exercício para a depleção e posterior supercompensação, representando uma linha de pensamento metodológico ainda não utilizado em estudos sobre este tema. Finalmente, a origem da fadiga em esforços com moderada duração seguidos de um esforço até a exaustão, semelhante ainda não foi investigada na literatura. Estes aspectos metodológicos e lacunas identificadas na literatura formam a "linha de pensamento" do experimento descrito no Capítulo 4 do documento principal.

\section{Influências do conteúdo de glicogênio sobre a origem da fadiga}

Após exercícios onde a depleção do glicogênio é pronunciada, as concentrações de ácidos graxos livres (AGL) aumentam, indicando que o metabolismo dos lipídeos deve ser predominante [113]. De fato, embora este estado fisiológico dependa de fatores como a duração e a intensidade do exercício prévio, o a preferência para oxidação de lipídeos pode continuar por vários dias, mesmo que a sejam fornecidas fontes de carboidrato [114]. Este panorama fisiológico indica a prioridade do organismo para repor o conteúdo de glicogênio depletado durante o exercício $[113,114]$. Para que isso ocorra, a AMPK continua ativa mesmo durante a recuperação, o que parece estar ligado a uma supressão da Piruvato Desidrogenase [21, 64]. Assim a glicose captada é rapidamente convertida em G6F mas não é utilizada para energia pela diminuição do fluxo no final da glicólise. Considerando que a quantidade de G6F é o principal ativador alostérico da GS, este ambiente muscular propicia a formação de glicogênio.

Desse modo, durante o esforço quando as concentrações de AGL estão aumentadas desde o repouso a taxa de utilização do glicogênio diminui [55]. Este "efeito protetor" dos AGL sobre a utilização do glicogênio induz uma maior utilização da via da $\beta$-oxidação, que possui uma potência inferior em relação à via glicolítica (i.e., menor energia por unidade de tempo) e, 
consequentemente, pode diminuir o desempenho em esforços próximos ao $\mathrm{VO}_{2 \mathrm{MAX}}$ ou realizados de maneira intermitente em alta intensidade. Embora esta explicação seja comumente aceita para explicar o menor desempenho em esforços com B-Glic, em esforços acima do $\mathrm{VO}_{2 \mathrm{MAX}}$ as fibras do tipo II são recrutadas logo no início do exercício, aumentando a necessidade da utilização da glicólise [10], o que pode atenuar este efeito poupador de glicogênio muscular. De fato, a manutenção do glicogênio em esforços intermitentes de alta intensidade com B-Glic ainda é pouco explorada na literatura. Balsom et al., [57], além de ter observado um efeito poupador menos expressivo do que os encontrados na literatura (i.e., degradação apenas 10\% menor em esforços com B-Glic), também observou elevadas concentrações sanguíneas de lactato após esforços intermitentes de alta intensidade, demonstrando que a glicólise também foi muito utilizada. Desse modo, mais estudos são necessários para que o metabolismo durante esforços com B-Glic seja mais bem elucidado. Neste sentido, acreditamos que investigações sobre a influência da quantidade de glicogênio sobre a origem da fadiga representam um importante avanço nesta área.

Além destes fatores relacionados ao metabolismo energético, a importância do glicogênio também tem sido demonstrada em outras funções musculares. Uma série de estudos desde 1999 tem demonstrado que a diminuição do glicogênio muscular, especialmente aquele armazenado entre as miofibrilas, possui um papel fundamental para a liberação do $\mathrm{Ca}^{++}$pelo retículo sarcoplasmático [7]. Um dos mais decisivos estudos sobre esta hipótese foi conduzido por Ortebland et al. [84], que determinou o papel da recuperação do glicogênio após um esforço de depleção. Para isso, os participantes receberam $1 \mathrm{~g} \cdot \mathrm{kg}^{-1} \cdot \mathrm{h}^{-1}$ nas primeiras $4 \mathrm{~h}$ de recuperação ou água. Os autores observaram que existe uma significativa correlação entre a capacidade do retículo em liberar o $\mathrm{Ca}^{++}$e a quantidade de glicogênio muscular, especialmente aquele armazenado entre as miofibrilas. Embora ainda estejam relacionados a fatores periféricos de 
fadiga, estes resultados demonstram uma função do glicogênio que vai além da bioenergética para o processo de pontes cruzadas.

Outra possível explicação para o comprometimento do desempenho em esforços com BGlic, pode estar relacionada a fadiga central [29, 30]. Neste tipo de esforço, observa-se um aumento da atividade simpática sobre o coração [31-33], provavelmente devido à elevação nos níveis de catecolaminas [34]. Este panorama fisiológico pode desencadear a função protetora do sistema nervoso central, conhecida como "modelo de governador central" [29, 30]. De acordo com este modelo, o sistema nervoso diminui a atividade muscular antes do desenvolvimento da fadiga periférica, protegendo órgãos como o cérebro e o coração, que são sensíveis as grandes alterações metabólicas induzidas pelo exercício [29, 30].

Embora o modelo de governador central seja uma teoria parcialmente aceita para explicar a fadiga em várias intensidades [29, 30, 35], sendo considerado um novo paradigma da fisiologia do exercício [36], seus mecanismos fisiológicos ainda são pouco conhecidos. Em esforços com B-Glic, o aumento das catecolaminas circulantes resulta na elevação das concentrações séricas de ácidos graxos livres (AgL), aumentando a quantidade sanguínea de triptofano livre (TrP-L) [25-27]. Este aminoácido atravessa a barreira hematoencefálica e desencadeia a formação cerebral de serotonina, o que possivelmente está relacionado a uma diminuição da atividade dos motoneurônios durante o exercício [27, 28]. Embora a influência do TrP-L seja estudada por meio de delineamentos com suplementação, este mecanismo fisiológico é apenas uma hipótese em esforços B-Glic.

\section{Considerações}

A partir das lacunas evidenciadas acima, podemos notar que embora quase um século tenha se passado desde o primeiro estudo envolvendo carboidratos e exercício, este assunto 
ainda representa um campo fértil para pesquisa.

Resumindo as perguntas levantadas após a revisão da literatura, podemos citar:

Qual é a origem da fadiga em esforços intermitentes realizados em intensidades acima do $\mathrm{VO}_{2 \mathrm{MAX}}$ utilizando as situações B-Glic e R-Glic?

Como as quantidades de glicogênio muscular influenciam na origem da fadiga em esforços até a exaustão realizados após exercícios de moderada duração?

A partir das respostas destas perguntas, as quais estão apresentadas principalmente nos Capítulos 3 e 4 do documento principal, acreditamos que a pergunta central da presente tese foi respondida de maneira satisfatória. 


\section{II - PADRONIZAÇÃO DO ERGÔMETRO PARA EXTENSÃO DE DINÂMICA DE JOELHOS (voltar ao documento principal)}

\section{O ergômetro original}

O ergômetro para extensão dinâmica de joelhos foi idealizado no instituto August Krogh, vinculado a universidade de Copenhagen, na Dinamarca. O primeiro artigo que investigou este modelo de exercício, foi escrito pelo pesquisador Per Andersen e outros colaboradores, dentre eles Bengt Saltin [51]. Esta publicação é considerada um marco na fisiologia do exercício, revolucionando os estudos sobre o metabolismo, fluxo sanguíneo e as respostas sobre a fadiga muscular [115-117].

Basicamente, neste ergômetro o movimento de pedalada em um cicloergômetro convencional é substituído por extensões consecutivas. Para isso, o pedal de um cicloergômetro de frenagem mecânica é substituído por uma haste metálica, posicionada paralelamente ao seu quadro. O avaliado é posicionado de costas para o cicloergômetro, sentado em uma cadeira específica com os joelhos em um ângulo de $90^{\circ}$ (posição inicial). O tornozelo do avaliado é fixo em uma bota metálica sendo conectada à haste por meio de uma célula de carga, o que permite a determinação da força realizada a cada extensão.

Durante cada extensão o pedivela do cicloergômetro completa um quarto de volta, movendo a articulação do joelho de um ângulo de $90^{\circ}$ até aproximadamente $170^{\circ}$. Considerando que o cicloergômetro possui uma catraca fixa, o sistema se mantem em movimento após a realização da extensão e, assim, a articulação do joelho volta ao ângulo de $90^{\circ}$ de maneira 
passiva (i.e., sem a contração dos músculos posteriores de coxa). Com isso, o quadríceps femoral é o principal agente motor durante o esforço [51]. Os ajustes na intensidade de exercício são realizados exatamente como em um cicloergômetro convencional, sendo mensurados em unidades de potência (i.e., Watts). O esquema ilustrativo do ergômetro, publicado na íntegra por Andersen et al. [51], está demonstrado na Figura 34.

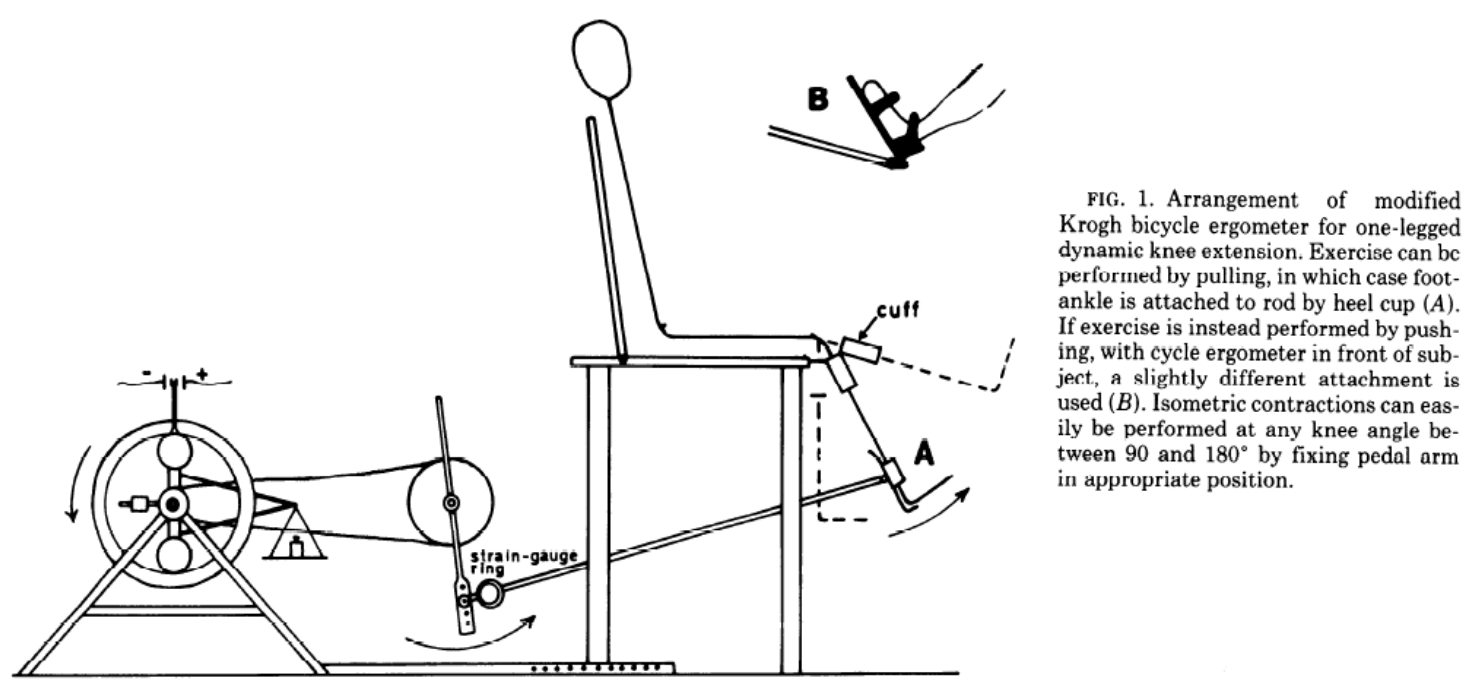

Figura 34. Figura publicada por Per Andersen e colaboradores (p. 1648), esquematizando o primeiro ergômetro de extensão dinâmica de joelho.

\section{O ergômetro atual}

Embora o artigo supracitado descreva em detalhes o ergômetro para a extensão dinâmica de joelho, originalmente o exercício foi padronizado de maneira unilateral [51]. De fato, quando utilizado da maneira original, as respostas fisiológicas e de desempenho apresentam valores inferiores em relação a utilização bilateral. Neste sentido, todos os procedimentos do projeto principal serão realizados por meio da extensão dinâmica de joelhos, realizada de maneira bilateral. Assim, esperamos uma menor diferença entre as respostas fisiológicas observadas com este modelo de exercício, em relação aos esforços tradicionalmente realizados em outros 
ergômetros (e.g. ciclismo).

Para isso, algumas modificações no ergômetro de extensão dinâmica de joelhos são necessárias, as quais já foram padronizadas no ergômetro original. Embora estas modificações ainda não tenham sido oficialmente documentadas em publicações científicas, contamos com duas fontes de informação para a construção do nosso ergômetro. As primeiras informações foram adquiridas por meio de fotografias e vídeos, obtidos pelos integrantes do nosso laboratório que regressaram do intercâmbio no instituto August Krogh. A segunda fonte de informação, foi o professor associado do instituto, Dr. Nikolai Baastrup Nordsborg, o qual gentilmente nos enviou o projeto do ergômetro utilizado em suas pesquisas.

Considerando estas observações, evidenciamos que à conexão entre as botas e a haste metálica precisava ser ajustada para a realização da extensão dinâmica de joelhos de maneira bilateral. Originalmente, esta conexão é realizada por uma célula de carga ou por uma articulação simples (Figura 35). Com as alterações, a extremidade da haste acaba em um semicírculo com diâmetro de $30 \mathrm{~cm}$, onde duas células de carga são posicionadas para a determinação da força realizada pelos dois membros inferiores (Figura 35). 


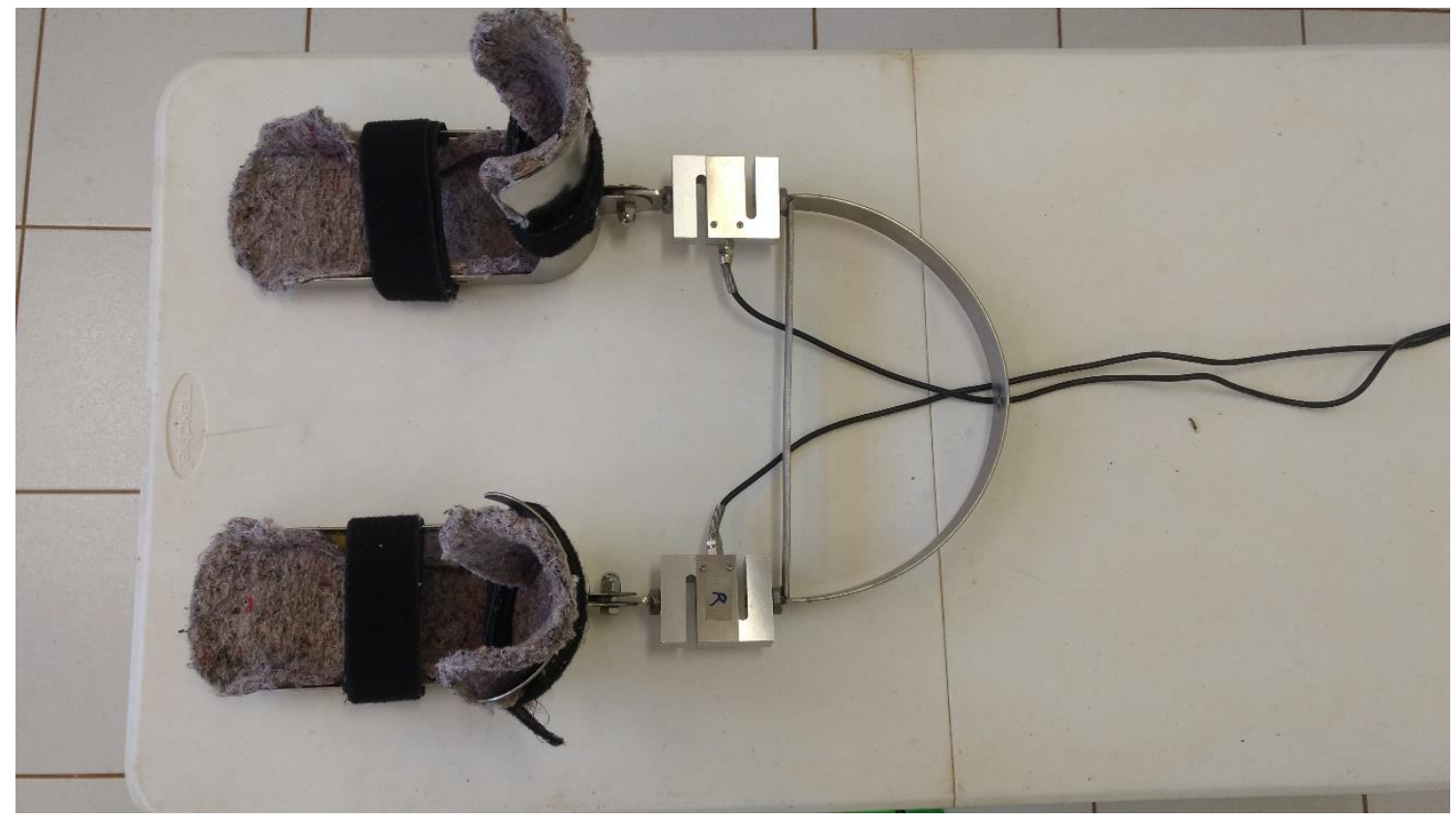

Figura 35. Semicírculo construído para conectar a haste metálica, as células de carga e as botas. Este aparato permite a realização da extensão dinâmica de joelhos de maneira bilateral.

Adicionalmente, outras alterações foram necessárias para adequar o projeto original do ergômetro à nossa realidade financeira. Embora todas as dimensões do ergômetro tenham sido mantidas, o projeto original prevê a utilização de barras quadradas em alumínio, com lados medindo $5 \mathrm{~cm}$. Este material diminuí o peso total do ergômetro, mas eleva demasiadamente o custo relacionado a sua construção. Com isso, optamos por utilizar barras metálicas simples, com lados medindo $3 \mathrm{~cm}$, as quais foram manipuladas por serralherias convencionais. Para atenuar o problema do peso, dividimos o ergômetro em duas partes (i.e., bloco onde o banco é fixado e base de suporte para o cicloergômetro), facilitando seu transporte, quando necessário. As partes distintas do ergômetro podem ser firmemente conectadas, o que não diminui a estabilidade durante as avaliações.

A haste metálica e as botas foram confeccionadas em inox, o que conferiu resistência e baixo peso a estas estruturas. Os avaliados são posicionados em um banco automobilístico, 
sendo fixados durante os esforços utilizando um cinto de competição (cinto de 4 pontas; Amicintos, São Paulo, Brasil). O banco é conectado ao ergômetro por meio de uma base ajustável tanto lateralmente como no sentido anteroposterior, conforme as dimensões do avaliado e o modelo de esforço (e.g., unilateral ou bilateral).

A frequência de extensões é controlada por meio de um dispositivo utilizando telemetria (CycleOps; Wiaconsin, EUA), posicionado na altura dos olhos do avaliado. Embora os esforços no ergômetro sejam realizados de maneira dinâmica, contrações isométricas são necessárias para a caracterização da fadiga pelas técnicas de TI e EMT. Com isso, a última alteração realizada no ergômetro está relacionada a fixação do pedivela no quadro da bicicleta ergométrica, que ocorre rapidamente por meio de uma haste de ferro desenhada exclusivamente para este propósito.

Todas as fases para a construção do ergômetro foram realizadas em um período de 17 dias e envolveram oito empresas diferentes. A Figura 36 ilustra a última versão do ergômetro construído pelo nosso grupo de pesquisa. Além disso, um vídeo demonstrando os passos para a construção e o funcionamento do ergômetro de extensão dinâmica de joelhos, está disponível $\begin{array}{llll}\text { em nosso } & \text { canal no } & \text { YouTube }\end{array}$ (https://www.youtube.com/watch?v=EF3zZMMPAPU\&feature=youtu.be; ou utilizando as palavras-chave: GECIFEX, dynamic, knee extension). 


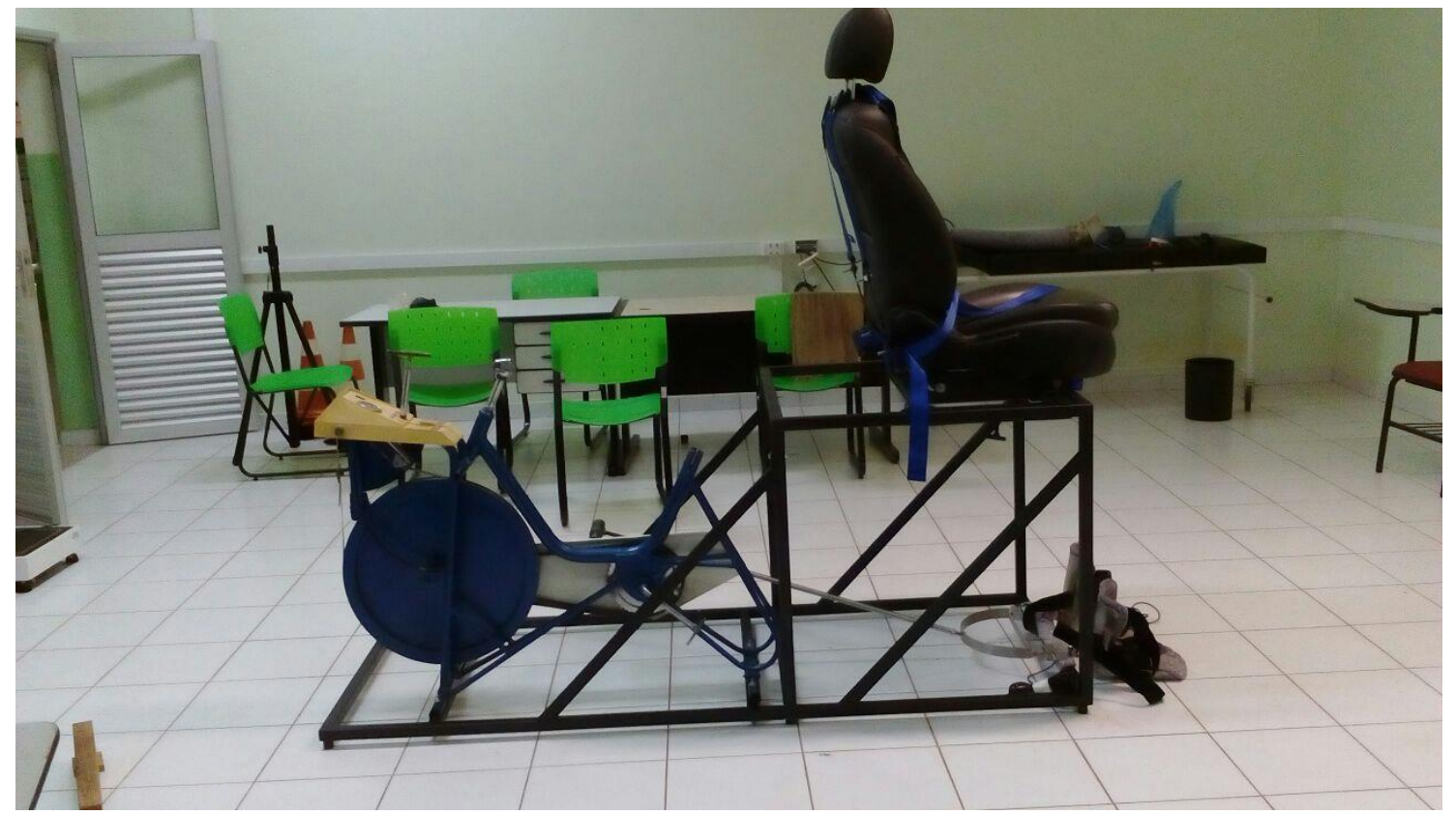

Figura 36. Última versão do ergômetro construído pelo nosso grupo de pesquisa.

\section{Procedimentos de calibração}

Antes da utilização do ergômetro para aquisição das respostas fisiológicas relacionadas a extensão dinâmica de joelhos, a frenagem mecânica da bicicleta ergométrica e as células de carga que conectam as botas ao semicírculo, foram calibradas para a correta determinação dos valores de força. Para isso, realizamos um conjunto de experimentos que coletivamente objetivaram a padronização destas calibrações, os quais estão apresentados nos próximos tópicos deste capítulo. A partir destes procedimentos, foi possível a determinação da potência durante os esforços, procedimento também descrito neste capítulo.

As células de carga utilizadas durante os experimentos foram confeccionadas pelo mesmo fabricante e possuíam capacidade de 50 ou $250 \mathrm{Kg}$ (CSR-1T, MK Controle, São Paulo - Brasil). O sinal foi adquirido por meio de uma placa de aquisição de sinais (NI-USB 6009, National Instruments ${ }^{\circledR}$ ), utilizando uma frequência de aquisição de 1000 Hz. A “tensão inicial” (i.e. valor de tensão obtido pela célula de carga imóvel e sem sofrer nenhum vetor de extensão ou 
compressão) foi zerada antes de todos os procedimentos por meio de ajustes no amplificador de sinais (Saída de 0 a 10 VDC; CSR-1T, MK Controle, Sao Paulo - Brasil). O sinal da força foi suavizado em filtro digital butterworth de ordem 3, com frequência de corte tipo passabanda de 0,3 e $5 \mathrm{~Hz}$, obtidas por meio da análise de resíduos [118].

Independentemente da célula de carga utilizada, os procedimentos de calibração consistiram na sobreposição de pesos conhecidos (e.g. 0 - 10,2 Kg; com incrementos variando entre 0,101 e 4,146 Kg). O sinal obtido pela célula de carga foi registrado por $10 \mathrm{~s}$ e a reta de calibração foi construída por meio da relação entre a média da tensão e o peso conhecido utilizado. Todos os procedimentos para a coleta da tensão e a construção da reta de calibração, foram realizados em ambiente Matlab®, utilizando aplicativos e rotinas desenvolvidas especificamente para este propósito.

\section{Calibração da frenagem mecânica}

O sistema de frenagem mecânica utilizado pelo cicloergômetro deve ser calibrado, garantindo a precisão nos implementos de carga durante a extensão dinâmica de joelhos. $\mathrm{O}$ cicloergômetro que será usado no presente projeto (Monark 828; Monark Exercise $\mathrm{AB}$, Vansbro, Suécia), utiliza um sistema de engrenagens e um pêndulo para os ajustes de tensão sobre a fita de frenagem mecânica. Embora este modelo não possua um display eletrônico que demonstre a tensão na fita, o pêndulo possui uma escala que mostra a força necessária para girar a roda do cicloergômetro (i.e., Quilograma-força ou kilopound). Assim, realizamos um experimento para testar se a força apontada pelo pêndulo é a mesma realizada pela fita de frenagem mecânica na roda do cicloergômetro.

O experimento foi dividido em duas fases. Na primeira, uma célula de carga foi posicionada na fita (Capacidade de $50 \mathrm{Kg}$ ), permitindo a determinação da tensão real aplicada pelo sistema de frenagem mecânica sobre a roda do cicloergômetro (Figura 37). Utilizando este 
posicionamento da célula de carga, foram realizados oito esforços de $30 \mathrm{~s}$ separados por $90 \mathrm{~s}$ de intervalo passivo. A cadência destes esforços foi mantida em $60 \mathrm{rpm}$ e a intensidade foi aumentada progressivamente considerando as diferentes marcações na escala do pêndulo (e.g., 0 - 3,5 Kg; com incrementos de $0,5 \mathrm{Kg}$ ). A média de tensão captada pela célula de carga nos últimos $10 \mathrm{~s}$ de cada esforço, foi ajustada linearmente em função das marcações na escala do pêndulo. Na segunda fase, a célula de carga foi retirada do ciclo ergômetro, sendo calibrada convencionalmente com a sobreposição de pesos conhecidos $(0-4,55 \mathrm{Kg}$; com incrementos variando entre 0,101 e 4,146 Kg), como descrito acima.

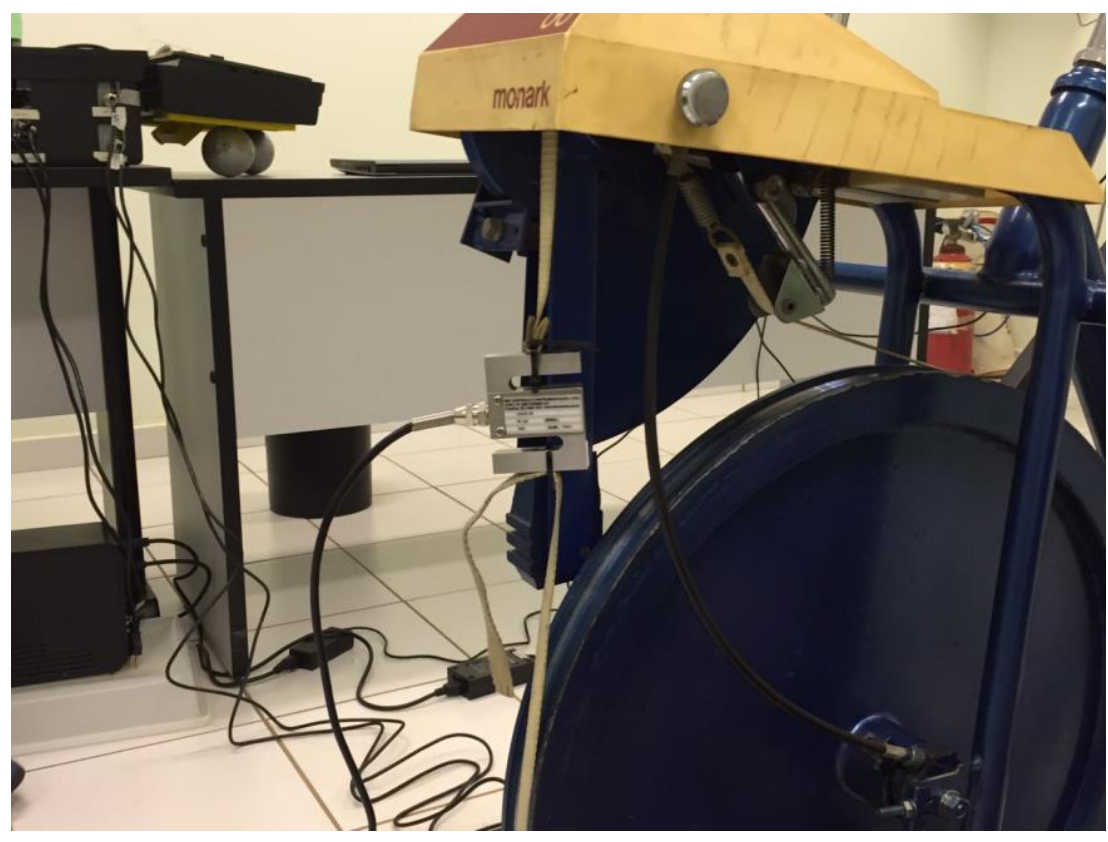

Figura 37. Posicionamento da célula de carga durante a primeira fase do experimento para calibração do sistema de frenagem mecânica.

Assim, dois ajustes lineares foram obtidos (i.e., tensão vs marcação do pêndulo e tensão vs peso conhecido), os quais estão apresentados na Figura 38. Ambos os ajustes apresentaram elevados índices de linearidade $\left(\mathrm{R}^{2}>0,993\right)$. As equações obtidas por estes ajustes lineares 
foram as seguintes:

Equação 1.

Equação 2.
Peso do pêndulo $=(28,629 \cdot$ Tensão $)-0,144$

Peso conhecido $=(29,874 \cdot$ Tensão $)-0,2355$

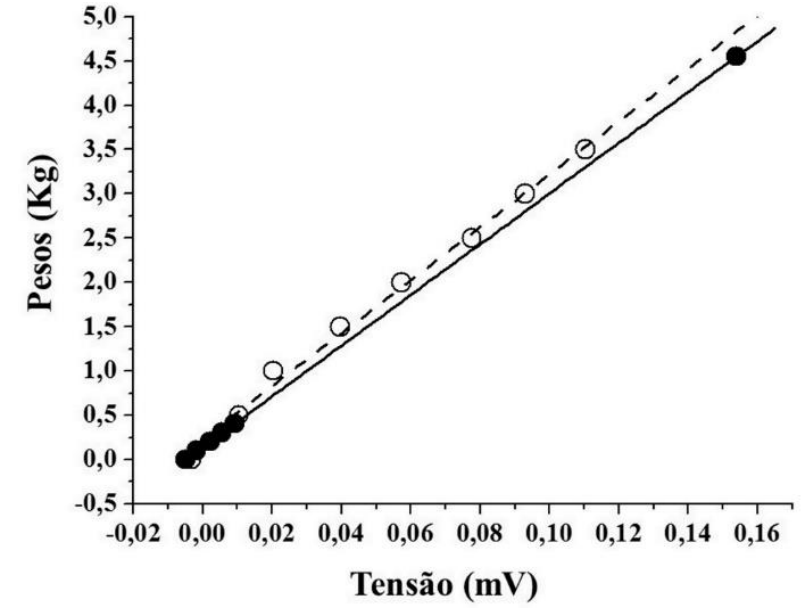

Figura 38. Relações lineares entre a tensão captada pela célula de carga na primeira fase (i.e., tensão $v s$ marcação do pêndulo; símbolos abertos) e na segunda fase (i.e., tensão vs peso conhecido; símbolos fechados) do experimento.

A sobreposição perfeita das retas indicaria que o sistema de frenagem mecânica aplica exatamente o peso apontado pelo pêndulo. Em outras palavras, quando o pêndulo estiver na escala de $1,5 \mathrm{Kg}$, a fita do sistema de frenagem gera uma tensão equivalente a 1,5 $\mathrm{Kg}$ na roda do cicloergômetro. Neste contexto, o sistema de frenagem mecânica estaria perfeitamente calibrado e poderia ser utilizado para a prescrição dos esforços e para a determinação da potência gerada.

Entretanto, podemos observar que a diferença entre as duas retas aumenta concomitantemente ao peso analisado. Este comportamento indica que quando a célula de carga capta elevadas tensões, os dois sistemas podem indicar diferentes pesos. Calculamos a magnitude destas diferenças por meio da análise de resíduo, o qual foi considerado como a 
diferença entre os pesos obtidos pelas equações 1 e 2 , assumindo diferentes valores de tensão. Embora o resíduo aumente linearmente com o aumento da tensão, seus valores não ultrapassaram 0,25 Kg (i.e. precisão mínima observada na escala do pêndulo) (Figura 39). Além disso, os maiores valores de resíduo $(0,2322 \mathrm{Kg})$ foram observados para uma tensão de 0,26 $\mathrm{mV}$, a qual seria observada com um peso equivalente a 7,5 $\mathrm{Kg}$ (i.e., $0,5 \mathrm{Kg}$ acima da capacidade máxima do sistema de frenagem mecânica).

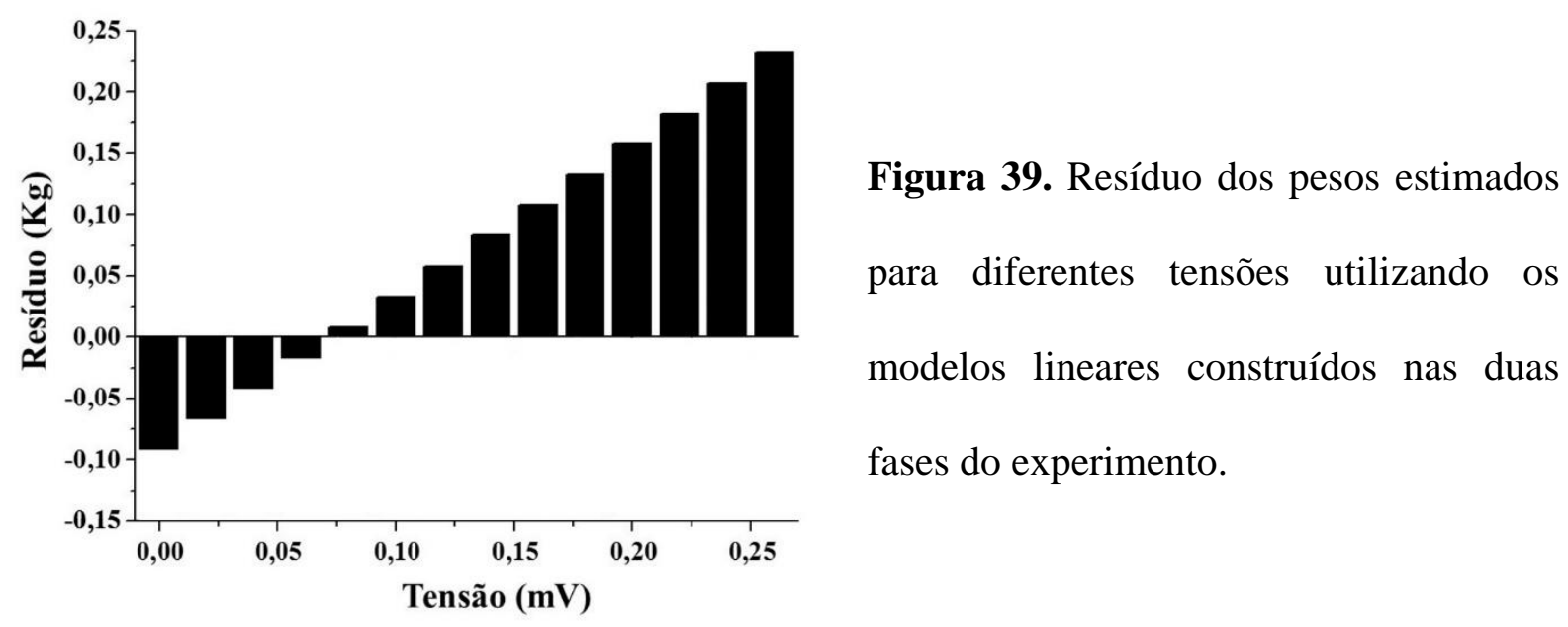

A magnitude das diferenças entre os dois modelos lineares construídos neste experimento, demonstra que a marcação do pêndulo pode ser utilizada para a determinação do peso imposto pelo sistema de frenagem do ciclo ergômetro. Assim, a fita de frenagem foi ajustada para gerar a mesma tensão de quando a célula de carga estava posicionada, implementando a mesma condição das aferições realizadas na primeira fase do experimento.

Embora este experimento tenha demonstrado a possibilidade de utilização das marcações do pêndulo, é possível que ocorra uma grande variabilidade inter-avaliadores durante a manipulação do sistema de frenagem mecânica. Este erro pode ocorrer principalmente pelo ângulo em que as marcações do pêndulo são observadas e/ou pela diferença no número de ajustes necessários para que a carga seja implementada (e.g. de 0,25 para 0,5 $\mathrm{Kg}$ uma volta 
completa é necessária, mas de 2,0 para 2,25 um quarto de volta na manivela é necessária). Considerando esta possibilidade, apenas um avaliador manipulou o sistema de frenagem mecânica durante os experimentos demonstrados nos próximos capítulos.

\section{Calibração das células de carga}

Para a realização da extensão dinâmica de joelhos, duas células de carga conectam as botas ao semicírculo (Capacidade de $250 \mathrm{Kg}$ ), o que permite a determinação tanto da cadência como da força gerada durante o exercício. A calibração das células de carga é a primeira etapa para a determinação destes parâmetros, sendo realizado por meio da sobreposição de pesos conhecidos, como descrito anteriormente. Aqui, as células de carga foram calibradas sobrepondo os pesos simultaneamente, utilizando o semicírculo e aproximando a situação de calibração daquelas observadas durante os esforços.

Atualmente em nosso laboratório, os procedimentos de calibração são realizados todos os dias de avaliação, antes ou após a realização de todos os testes. Entretanto, o sistema de aquisição de dados pode apresentar variações entre os dias e/ou momentos de avaliação. Assim, realizamos dois procedimentos para a padronização da calibração das células de carga, os quais responderam as duas questões apresentadas abaixo.

\section{É necessário realizar o procedimento de calibração todos os dias de avaliação?}

Para responder esta questão, realizamos 10 calibrações em diferentes dias, desligando o sistema de aquisição de dados entre as coletas (i.e. situação rotineira durante a coleta de projetos). Testamos a estabilidade das calibrações por meio dos valores de coeficiente de variação $\left(\mathrm{CV} \%=\right.$ Desvio padrão $\left.\cdot \mathrm{Média}^{-1} \cdot 100\right)$, calculados tanto para os parâmetros das regressões lineares como para o peso estimado para a tensão de $0,5 \mathrm{mV}$.

A Figura 40 demonstra as regressões lineares obtidas nos diferentes dias, as quais 
demonstraram elevados coeficientes de determinação (i.e., $\mathrm{R}^{2}>$ 0,9995). Embora os pesos conhecidos tenham sido exatamente os mesmos, foram observadas variações nos valores de tensão entre os dias de coleta. Além disso, as regressões lineares não foram sobrepostas e/ou paralelas, indicando que a relação entre a tensão captada e o peso conhecido é diferente entre as duas células de carga.

A Figura 41 demonstra os valores dos coeficientes angulares e lineares observados a cada calibração. O coeficiente angular apresentou elevada estabilidade entre as 10 calibrações, o que é confirmado pelos baixos valores de CV\% (célula $1=0,937 \%$; célula $2=0,638 \%$ ). Estes valores demonstram que para cada quilo de peso adicionado durante a calibração, a célula de carga 1 aumenta em média $0,0087 \mathrm{mV}$ e a célula de carga 2 aumenta $0,0121 \mathrm{mV}$. Diferentemente, o coeficiente linear não apresentou uma estabilidade satisfatória entre as calibrações (célula $1=126,6 \%$; célula $2=772,11 \%$ ). Quando o peso estimado para a tensão de $0,5 \mathrm{mV}$ é calculado (Figura 42), as maiores diferenças entre os dias de avaliação foram de 2,25 Kg para a célula de carga 1 e 2,70 Kg para a célula de carga 2, levando a baixos valores de CV\% (célula $1=1,52 \%$; célula $2=1,67 \%$ ).

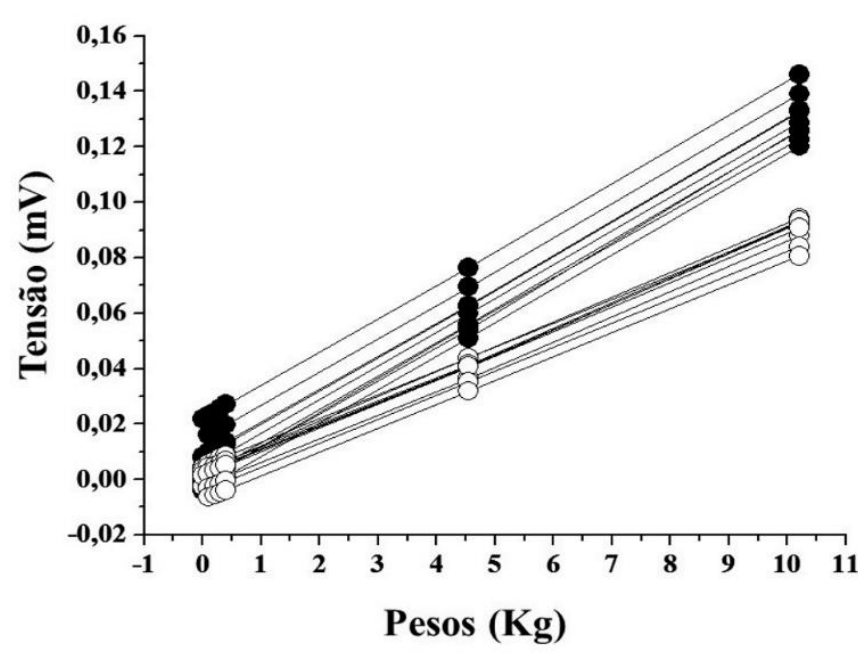

Figura 40. Regressões lineares construídas entre a tensão captada pelas células de carga (símbolos abertos: célula 1; símbolos fechados: célula 2), ao longo de 10 dias de avaliação. 

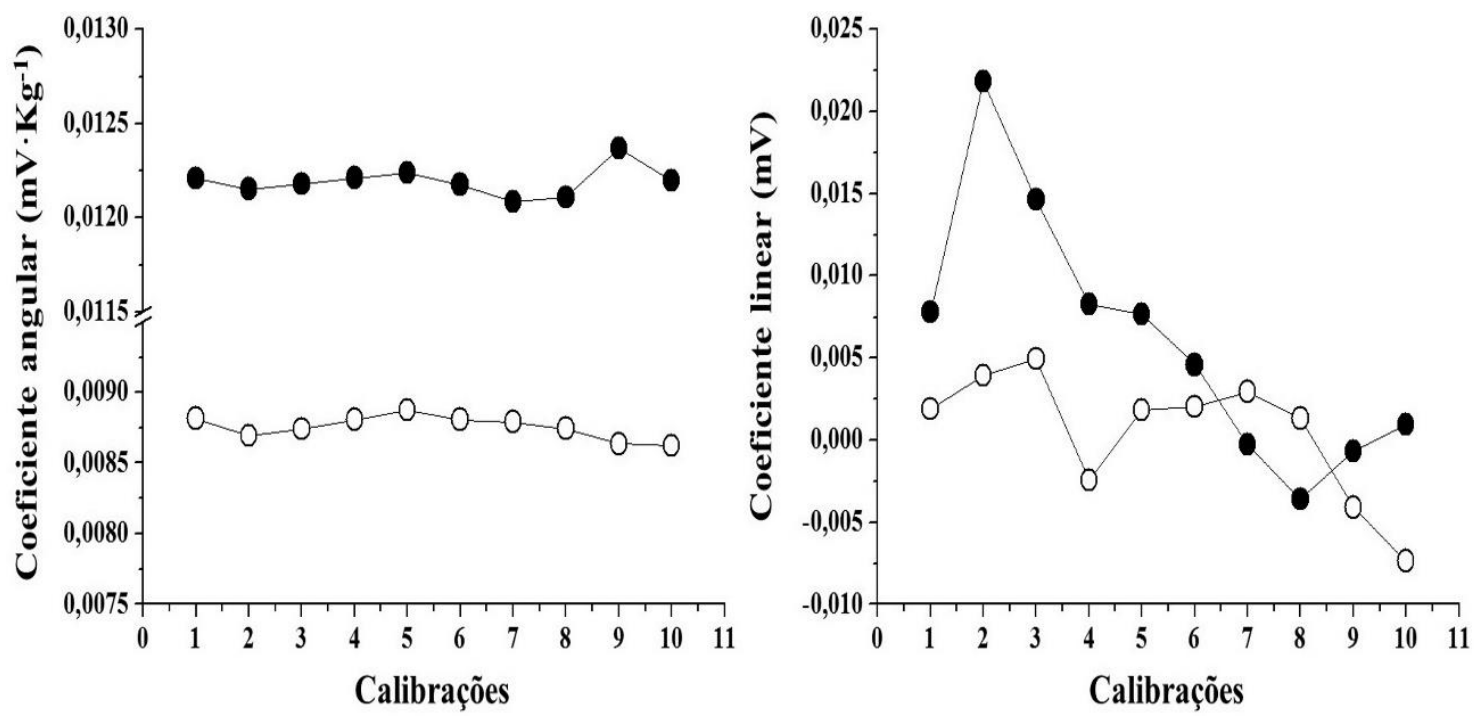

Figura 41. Coeficientes angulares e lineares obtidos nas calibrações realizadas em diferentes dias de coleta, utilizando as duas células de carga (símbolos abertos: célula 1; símbolos fechados: célula 2).

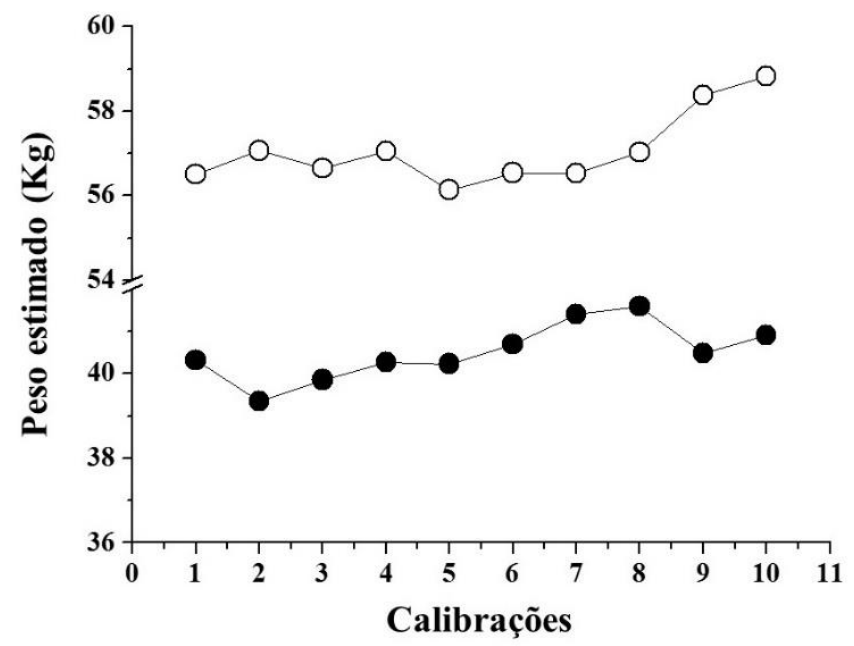

Figura 42. Pesos estimados para a tensão de $0,5 \mathrm{mV}$, utilizando as regressões construídas ao longo de 10 dias de avaliação pelas duas células de carga (símbolos abertos: célula 1; símbolos fechados: célula 2).

Qual é a variação dos parâmetros de calibração ao longo de dias consecutivos de coleta sem 


\section{desligar o sistema de aquisição?}

Consideramos esta questão de extrema importância na prática, principalmente por testar se existem diferenças entre as calibrações realizadas no início e no final do dia de avaliações (i.e., antes ou após todos os testes). Assim, 26 calibrações foram realizadas ao longo de quatro dias consecutivos entre as 8:00 h e as 22:00 h. As calibrações tiveram duração média de 11,33 min, sendo realizadas consecutivamente ou separadas por intervalos entre 2 min e $12 \mathrm{~h}$. Neste experimento, a "tensão inicial” foi zerada para as duas células de carga apenas no primeiro dia. O sistema de aquisição de dados permaneceu ligado durante os três primeiros dias, sendo desligado entre o terceiro e o quarto dia de avaliação. Esta estratégia foi realizada para que pudéssemos testar a necessidade de zerar a "tensão inicial" e/ou ligar o sistema de aquisição de dados no dia anterior as coletas.

A Figura 43 demonstra os valores de tensão captados pelas células de carga em função dos pesos conhecidos, em todas as calibrações realizadas. Claramente, a célula de carga 2 apresentou maiores variações em relação a célula de carga 1. Os valores obtidos a cada dia demonstram que a célula de carga 2 apresentou maiores variações no primeiro e no quarto dia, o que não ocorreu no segundo e no terceiro dia de avaliações (Figura 44).

A Figura 45 demonstra os valores dos coeficientes angular e linear obtidos ao longo dos quatro dias de avaliação. Claramente, o ajuste da "tensão inicial”, influenciou nos parâmetros das calibrações realizadas no primeiro dia, especialmente os valores de coeficiente linear da célula de carga 2. Além disso, o desligamento do sistema de aquisição entre o terceiro e quarto dia de avaliação, também influenciou nos valores obtidos para a calibração da célula de carga 2. De fato, o CV\% calculado entre as calibrações de cada dia, confirmam as maiores variações no primeiro e quarto dia de avaliações (Tabela 1). Estes resultados também foram observados para o peso estimado em $0,5 \mathrm{mV}$ (Tabela 1), os quais estão apresentados na Figura 46. Além 
disso, as maiores diferenças entre os pesos estimados foram observadas no primeiro dia de avaliações, sendo 0,57 e 1,33 Kg para as células de carga 1 e 2, respectivamente.

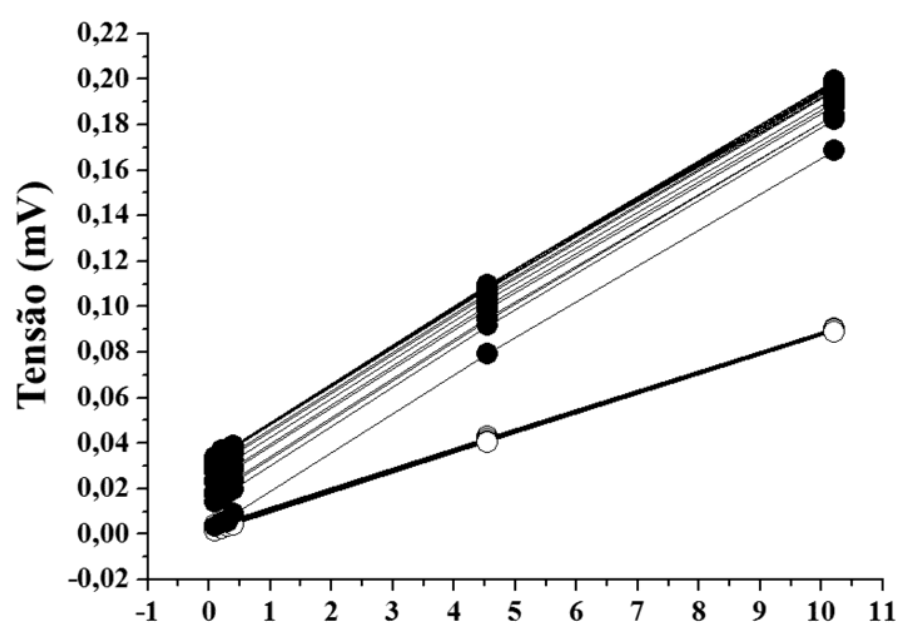

Figura 43. Regressões lineares construídas entre a tensão captada pelas células de carga (símbolos abertos: célula 1; símbolos fechados: célula 2), ao longo de quatro dias de avaliação.

\section{Pesos (Kg)}
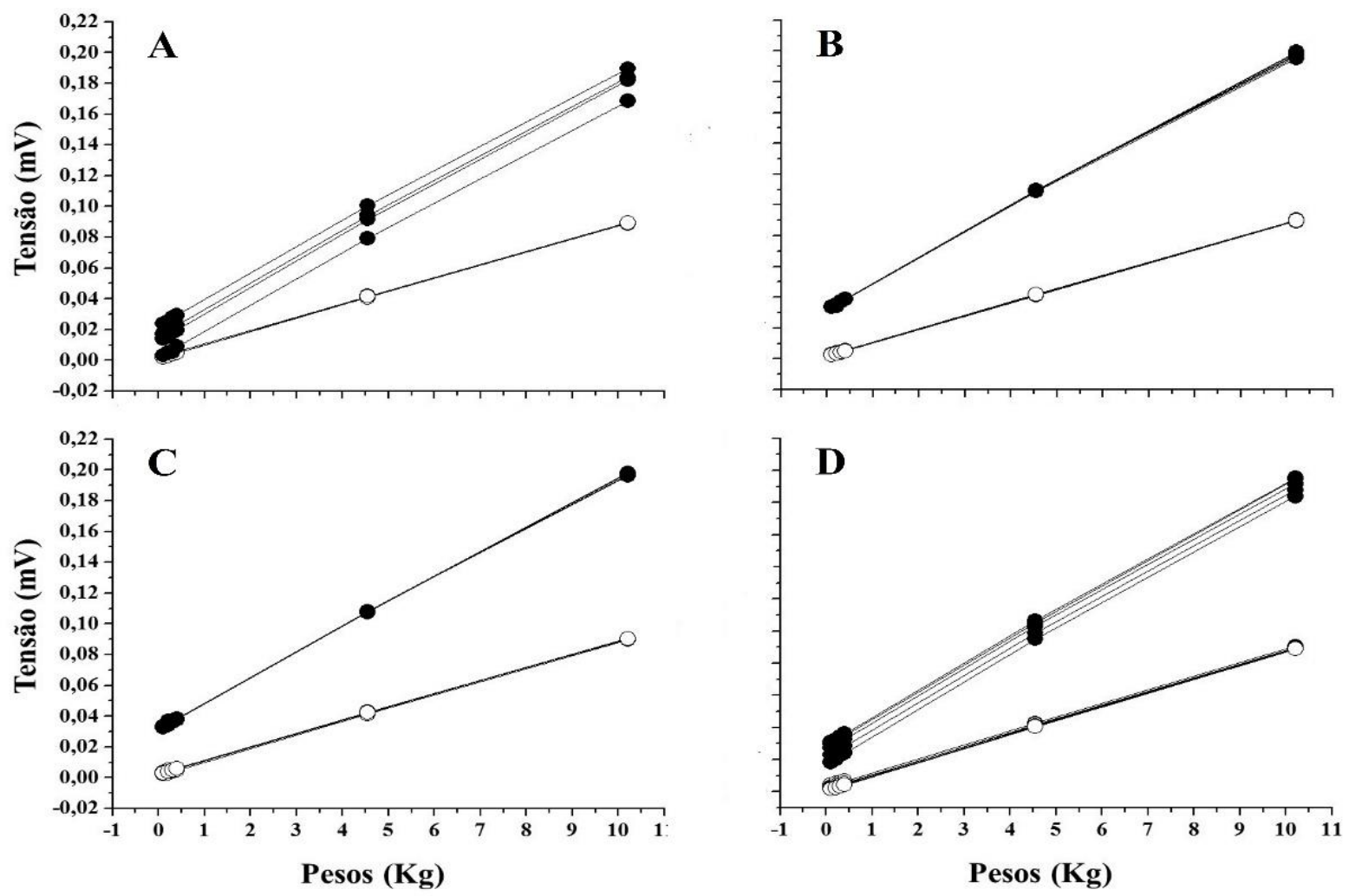

Figura 44. Regressões lineares construídas entre a tensão captada pelas células de carga 
(símbolos abertos: célula 1; símbolos fechados: célula 2), ao longo do primeiro (A), segundo (B), terceiro (C) e quarto (D) dias de avaliação.
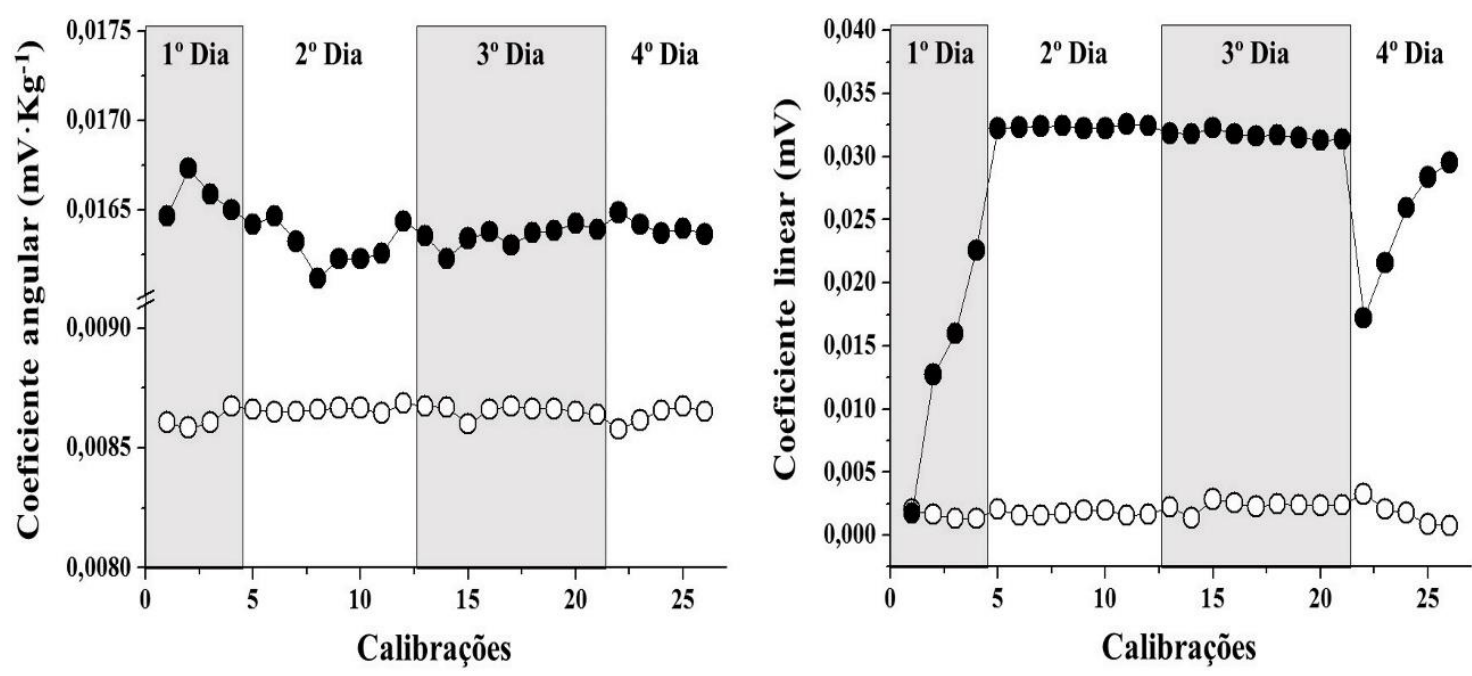

Figura 45. Coeficientes angular e linear obtidos durante as calibrações realizadas ao longo de quatro dias de avaliação, utilizando duas células de carga (símbolos abertos: célula 1; símbolos fechados: célula 2). A “tensão inicial” foi zerada no primeiro dia e o sistema de aquisição foi desligado entre o terceiro e quarto dia de avaliação.

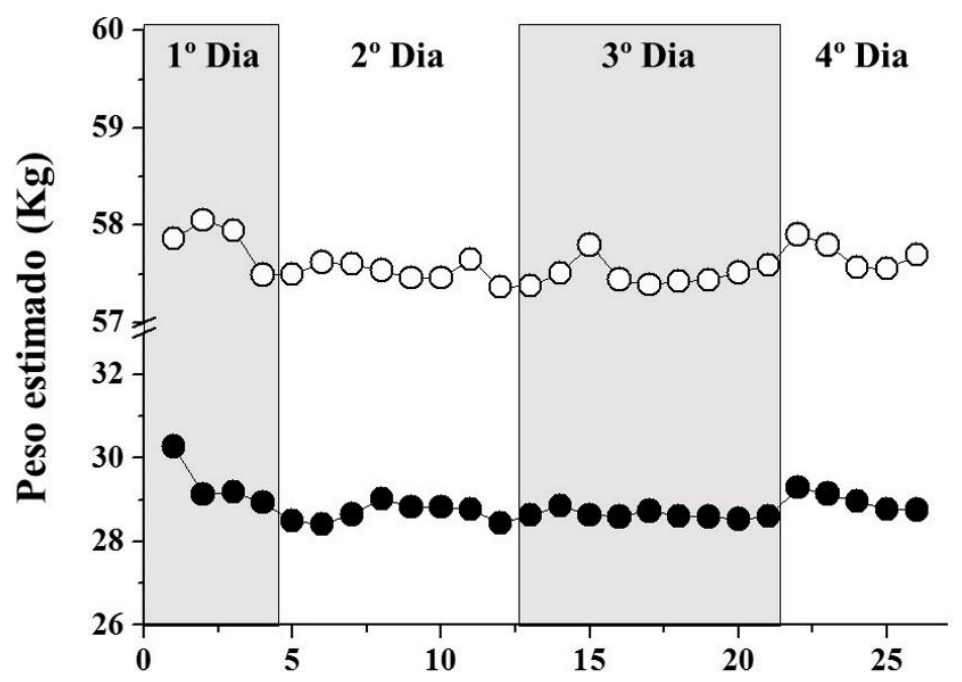

Calibrações
Figura 46. Pesos estimados para a tensão de $0,5 \mathrm{mV}$, utilizando as regressões construídas ao longo de 10 dias de avaliação pelas duas células de carga (símbolos abertos: célula $1 ;$ símbolos fechados: célula 2). 
Tabela 1. Coeficientes de variação, obtidos entre as calibrações realizadas ao longo dos quatro dias de avaliação, nas duas células de carga.

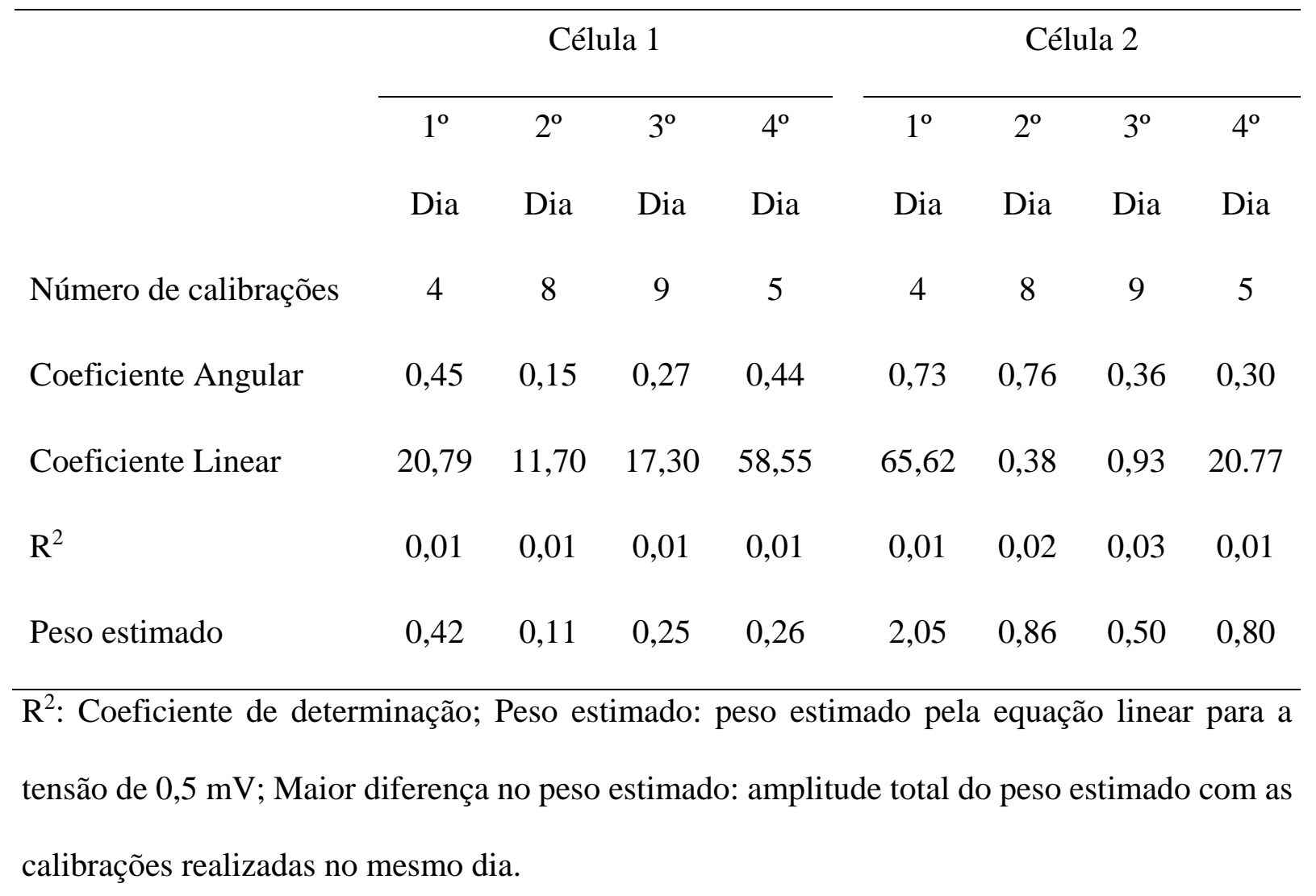

\section{Inferências sobre a calibração das células de carga}

Os resultados observados nos dois procedimentos demonstram que:

- Grandes variações nos valores de tensão são observadas entre diferentes dias de avaliação, o que pode ser explicado pelos distintos valores do coeficiente linear (i.e., valor "zero" de tensão). Embora o sistema de aquisição permita o ajuste dos valores de tensão próximos a zero, é pouco provável que este procedimento seja reprodutível entre os dias de 
avaliação. Este problema metodológico indica que as células de carga devem ser calibradas diariamente, corrigindo os diferentes valores de tensão inicial.

- As diferenças entre as calibrações levaram a uma variação de até 2,70 Kg, quando o sistema de aquisição foi desligado entre as coletas. Considerando que os esforços no ergômetro de extensão de joelhos podem gerar valores de força equivalentes a $700 \mathrm{~N}$ (e.g., contrações voluntarias máximas isométricas), a variação entre as calibrações pode gerar um erro de até 27 $\mathrm{N}$, o que deve ser considerado ao longo do projeto principal. Estes valores reforçam a necessidade de padronização dos procedimentos de calibração.

- Quando as calibrações foram realizadas ao longo de dias consecutivos, foram observados valores muito estáveis, principalmente no segundo e terceiro dia de avaliações. Além disso, zerar a "tensão inicial" parece comprometer a estabilidade das calibrações (primeiro dia do segundo procedimento), o que também ocorre com o desligamento do sistema de aquisição de dados (quarto dia do segundo procedimento). Considerando estes resultados e as baixas variações no peso estimado para $0,5 \mathrm{mV}$ no segundo e terceiro dia de avaliações, o sistema de aquisição de dados deve ser ligado no dia anterior ao início das coletas e, se possível, permanecer ligado até o final dos procedimentos propostos.

- Embora possuam a mesma capacidade (i.e., $250 \mathrm{Kg}$ ) e sejam fabricadas pela mesma empresa (CSR-1T, MK Controle, Sao Paulo - Brasil), as duas células de carga apresentam valores distintos de tensão para o mesmo peso conhecido. Estes achados indicam que distintas regressões lineares devem ser construídas para as diferentes células de carga utilizadas.

Considerando os achados destes procedimentos, todos os cuidados metodológicos apontados acima foram aplicados durante os experimentos do próximo capitulo e serão utilizados no decorrer do projeto principal. 


\section{Sinal da força e determinação da potência}

A partir das padronizações relacionadas ao sistema de frenagem mecânica e aos procedimentos de calibração das células de carga, foi possível a caracterização do sinal da força durante diferentes esforços no ergômetro de extensão dinâmica de joelhos.

O comportamento típico da força durante as extensões dinâmicas de joelho está apresentado na Figura 47. Estes sinais foram obtidos durante um esforço de cinco minutos com cadência de $60 \mathrm{rpm}$ e carga no sistema de frenagem mecânica equivalente a 1,5 $\mathrm{Kg}$, realizado por um participante com experiência prévia no ergômetro. O maior pico de força observado $(I)$ corresponde ao momento da extensão de joelhos. O segundo pico de força (II) é evidenciado quando o pedivela traciona a haste metálica para trás, fazendo com que a perna se posicione novamente para a próxima extensão. Antes da próxima extensão, valores negativos de força são observados $(I I I)$, o que pode ser atribuído a uma rápida compressão da célula de carga pela perna [51]. Embora este comportamento da força seja muito similar ao observado por Andersen et al. [51], estes autores observaram uma estabilização dos valores de força antes da próxima contração. Em nossos experimentos estes valores estáveis não foram observados, provavelmente pelo comprimento do pedivela, o qual é ligeiramente menor ao observado em outros ergômetros de extensão dinâmica de joelhos. Esta característica diminui a velocidade angular do pedivela, deixando o movimento mais dinâmico. Acreditamos que estas pequenas diferenças terão poucas influências nas respostas fisiológicas induzidas por este modelo de exercício. 


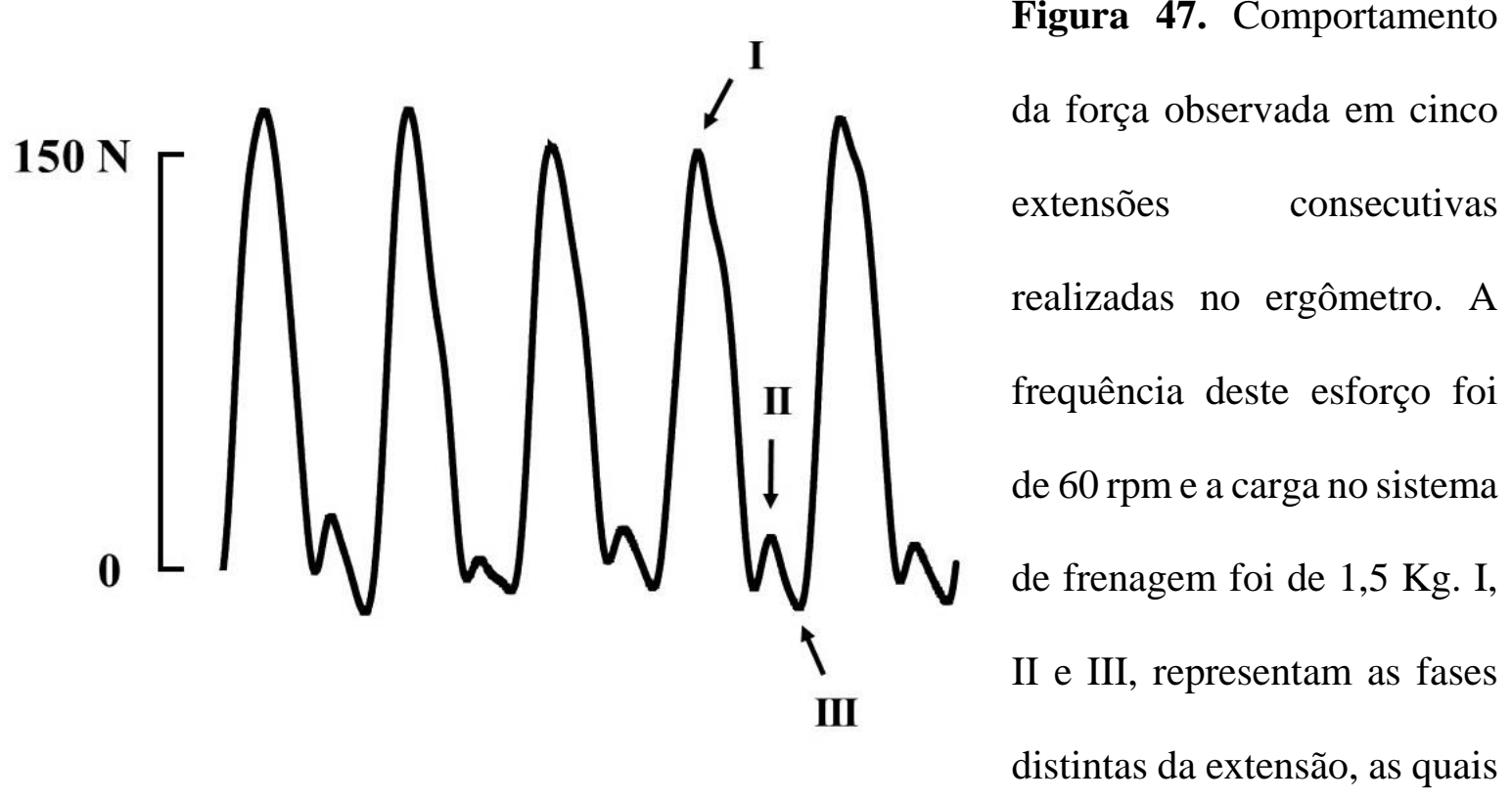

estão descritas no texto.

A partir da caracterização da força, foi possível a determinação da potência durante os esforços no ergômetro de extensão dinâmica de joelhos. A potência pode ser definida como o produto entre a força aplicada e a velocidade atingida em um certo instante [119]. Considerando que a velocidade é obtida pela relação entre a distância e o tempo, a potência pode ser definida pela seguinte equação:

Equação 3.

Potência $=$ Força $\cdot \Delta \mathrm{S} \cdot \Delta \mathrm{t}^{-1}$

Onde: A Força é expressa em Newtons, $\Delta \mathrm{S}$ representa o deslocamento e $\Delta \mathrm{t}$ é o espaço de tempo analisado.

Quando mensurada por meio de um cicloergômetro convencional, a potência gerada é o produto entre a carga aplicada pelo sistema de frenagem mecânica (i.e., força; $\mathrm{Kg}$ ), a distância percorrida pela roda após uma volta do pedivela (i.e., deslocamento; m.rev ${ }^{-1}$ ) e a cadência (i.e., 
número de voltas por unidade de tempo; rev. $\min ^{-1}$ ) [120]. A roda do ciclo ergômetro utilizado para as extensões de joelho possui $51,4 \mathrm{~cm}$ de diâmetro. Considerando que a cada volta do pedivela são realizadas 3,3 voltas na roda do cicloergômetro, a cada ciclo completo de pedalada são percorridos 5,30 m. Assim, a potência no presente projeto pode ser determinada por meio da seguinte equação:

Equação $4 . \quad$ Potência $\left(\mathrm{Kg} \cdot \mathrm{m} \cdot \mathrm{min}^{-1}\right)=$ Força $\cdot \Delta \mathrm{S} \cdot$ Cadência

Onde: A Força é determinada pela carga do sistema de frenagem mecânica $(\mathrm{Kg}), \Delta \mathrm{S}$ é a distância percorrida pela roda a cada revolução do pedivela $\left(5,30 \mathrm{~m} \cdot \mathrm{rev}^{-1}\right)$ e Cadência é o número de revoluções do pedivela por minuto $\left(\right.$ rev. $\left.\mathrm{min}^{-1}\right)$. Para que a potência seja expressa em Watts, o resultado desta equação deve ser multiplicado por $0,16344416$.

Além da tração imposta pelo sistema de frenagem mecânica, teoricamente a potência também poderia ser determinada por meio dos sinais de força obtidos com as células de carga posicionadas no semicírculo. Embora Andersen et al. [51] tenham observado uma relação linear entre os valores de potência, pequenas diferenças foram observadas utilizando o sistema de frenagem e as células de carga. Os autores atribuem estas diferenças ao pressuposto de que a força durante as revoluções é constante, o que não é verdade (e.g., Figura 47).

Para que os sinais obtidos pelas células de carga possam ser utilizados para a determinação da potência, a força durante os ciclos deve ser desmembrada em vários momentos, o que necessita da sincronização entre os ângulos dos membros inferiores e o posicionamento tanto da haste metálica como do pedivela. Apesar Ferguson et al. [121] terem realizado uma descrição detalhada deste procedimento, seus cálculos foram conduzidos utilizando a extensão de joelho unilateral, indicando que tais procedimentos não devem ser 
simplesmente transferidos para o modelo bilateral.

Neste contexto, considerando a relação linear entre as formas de determinação e facilidade de obtenção dos valores de força utilizando as marcações do pêndulo, no presente projeto a potência será calculada utilizando a carga imposta pelo sistema de frenagem mecânica, assim como ocorre na maioria dos estudos que utilizam a extensão dinâmica de joelhos.

Embora a carga imposta pelo sistema de frenagem mecânica seja facilmente obtida pela observação do pêndulo, o cicloergômetro utilizado não possui um sistema integrado para a determinação da cadência durante os esforços. Durante os experimentos, a cadência foi apresentada ao avaliado em tempo real por meio de um dispositivo de telemetria (CycleOps; Wiaconsin, EUA), possibilitando a manutenção desta variável durante os esforços.

Desse modo, quantificação da cadência foi realizada posteriormente, utilizando o sinal de força obtido pelas células de carga, considerando-se cada extensão como o maior pico de força observado (i.e., momento I da Figura 47). Os picos de força foram contabilizados por meio de uma rotina em ambiente MatLab®, desenvolvida especialmente para este propósito. Assim, a cadência foi assumida como a relação entre o número de picos e o tempo analisado (Equação 5), possibilitando a determinação da potência durante os esforços.

Equação 5.

Cadência $(\mathrm{rpm})=\mathrm{N}^{\mathrm{o}} \mathrm{Picos} \cdot \Delta \mathrm{t}^{-1}$

Onde: $\mathrm{N}^{\circ}$ Picos é o número de picos de tensão captados pelas células de carga e $\Delta$ t é o tempo de exercício analisado (min).

Por fim, para a determinação do trabalho realizado a média dos picos foi multiplicada pela cadênicia e pela distância a cada volta.

Equação 6.

Trabalho $(\mathrm{J})=\mathrm{FM}^{*}$ Cadência $^{*} \Delta \mathrm{S}$ 
Onde: A FM é a média dos picos obtidos no sinal de força, Cadência é o número de revoluções do pedivela por minuto (rev.min ${ }^{-1}$ ) e $\Delta \mathrm{S}$ é a distância percorrida pela roda a cada revolução do pedivela $\left(5,30 \mathrm{~m} \cdot \mathrm{rev}^{-1}\right)$. 


\section{III - RESPOSTAS FISIOLÓGICAS E PADRONIZAÇÃO DO ESFORÇO NO ERGÔMETRO PARA EXTENSÃO DE DINÂMICA DE JOELHOS (voltar ao documento principal)}

\section{Experimento 1 - As respostas eletromiográficas}

\section{Contextualização}

A principal vantagem na utilização da extensão dinâmica de joelhos é isolar o músculo de interesse durante a atividade. No projeto principal, esta abordagem irá permitir que todas as medidas relacionadas ao estudo da fadiga sejam obtidas num músculo com baixas quantidades de glicogênio. Além disso, todas as respostas sistêmicas (e.g., analises sanguíneas, consumo de oxigênio ( $\left.\dot{\mathrm{VO}}_{2}\right)$ e frequência cardíaca $\left.(\mathrm{FC})\right)$ serão induzidas pelo trabalho apenas do quadríceps. Acreditamos que este cuidado metodológico aumentará a robustez dos resultados obtidos no projeto principal.

Com isso, para garantir que esta vantagem está sendo aplicada durante o exercício, conduzimos um experimento para monitorar a atividade do vastus lateralis e do biceps femoris durante esforços progressivos utilizando a extensão dinâmica de joelhos.

\section{Materiais e Método}

Seis participantes (idade de $26 \pm 6$ anos, estatura de $181,2 \pm 8,2 \mathrm{~cm}$ e peso corporal de $92,0 \pm 13,7 \mathrm{Kg}$ ) foram submetidos a um esforço progressivo, que foi precedido de um aquecimento de sete minutos com intensidade de $12 \mathrm{~W}$. O esforço progressivo iniciou a $25 \mathrm{~W}$ e teve incrementos de $25 \mathrm{~W} \cdot \mathrm{min}^{-1}$, aplicados até a exaustão voluntária.

Durante os esforços a atividade eletromiográfica dos músculos vastus lateralis e biceps

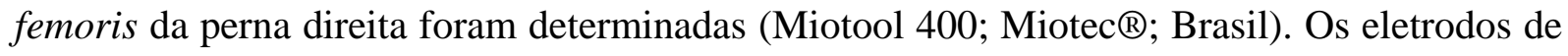
$\mathrm{Ag} / \mathrm{AgCl}$ com área de captação de $1 \mathrm{~cm}(3 \mathrm{M} 囚$, São José do Rio Preto - Brasil) foram 
posicionados segundo as diretrizes do SENIAM, após os pontos anatômicos serem tricotomizados e higienizados com álcool 70\%. Em todos os casos, o sinal eletromiográfico foi adquirido com uma frequência de $2000 \mathrm{~Hz}$ e ganho de 1000 vezes (Miograph; Miotec®; Brasil), o que posteriormente foi filtrado por meio de filtro passa-banda de 20-500 Hz. As últimas dez contrações (i.e., 10 s de exercício) foram utilizadas para a determinação da root mean square (RMS), que foi assumida como índices de ativação muscular.

Considerando a confirmação da normalidade por meio do teste de Shapiro-Wilk, os dados foram apresentados em média \pm desvio padrão. Entretanto, considerando o número reduzido de participantes, para que o erro da não uniformidade fosse evitado, as possíveis diferenças entre as respostas dos músculos vastus lateralis e biceps femoris foram testadas pelo teste de Wilcoxon. Estas análises foram realizadas pelo software SPSS 17.0 (SPSS Inc, Chicago, Illinois), com o nível de significância fixado em $p$-valor $<0,05$.

\section{Resultados e inferências}

O comportamento do sinal eletromiográfico de um participante está apresentado na Figura 48. O comportamento individual da RMS nos músculos vastus lateralis e biceps femoris está apresentado na Figura 49. Para todos os participantes, a RMS do vastus lateralis apresentou valores superiores aos observados para o biceps femoris. De fato, a estatística inferencial confirmou que, embora a RMS do vastus lateralis tenha aumentado concomitantemente a intensidade, os valores observados no biceps femoris não foram alterados durante o exercício até a exaustão (Figura 50). 


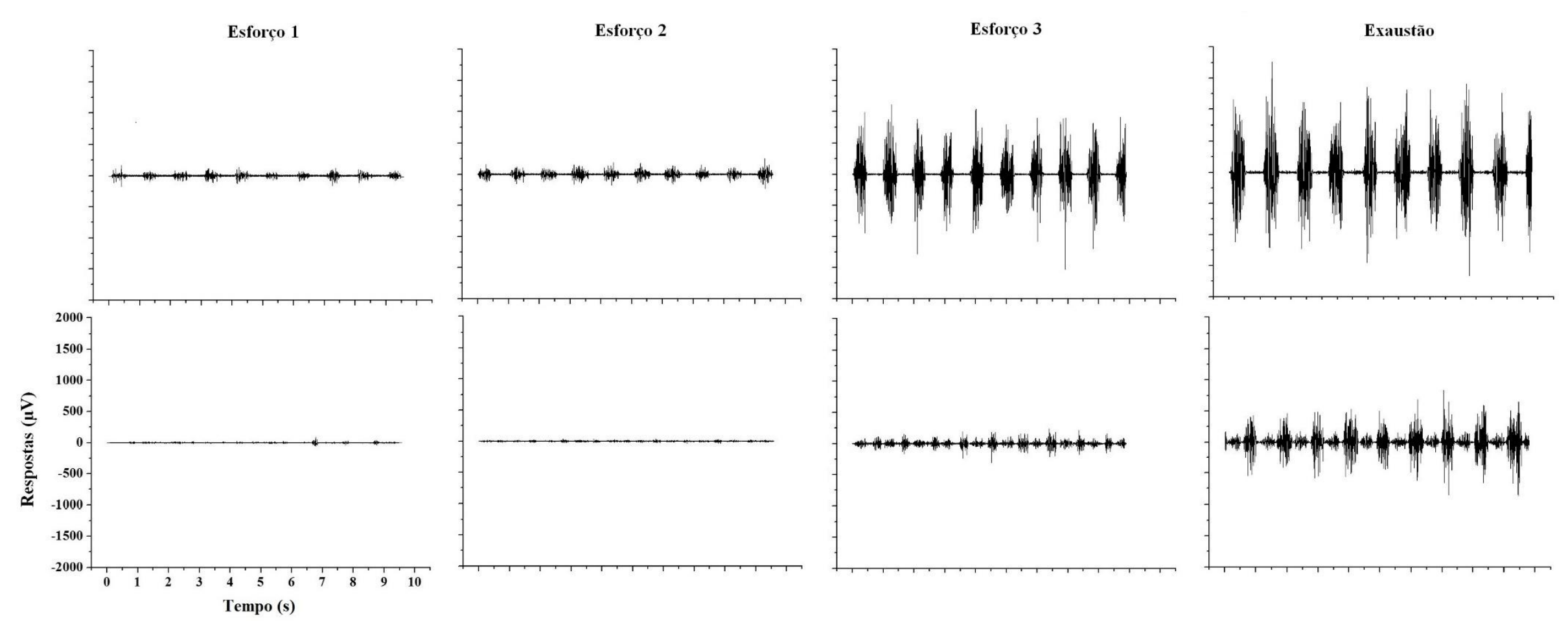

Figura 48. Comportamento individual das respostas eletromiográficas apresentadas ao longo de quatro esforços progressivos nos músculos vastus lateralis (painéis superiores) e biceps femoris (painéis inferiores). Os valores de escala foram mantidos em todos os gráficos. 

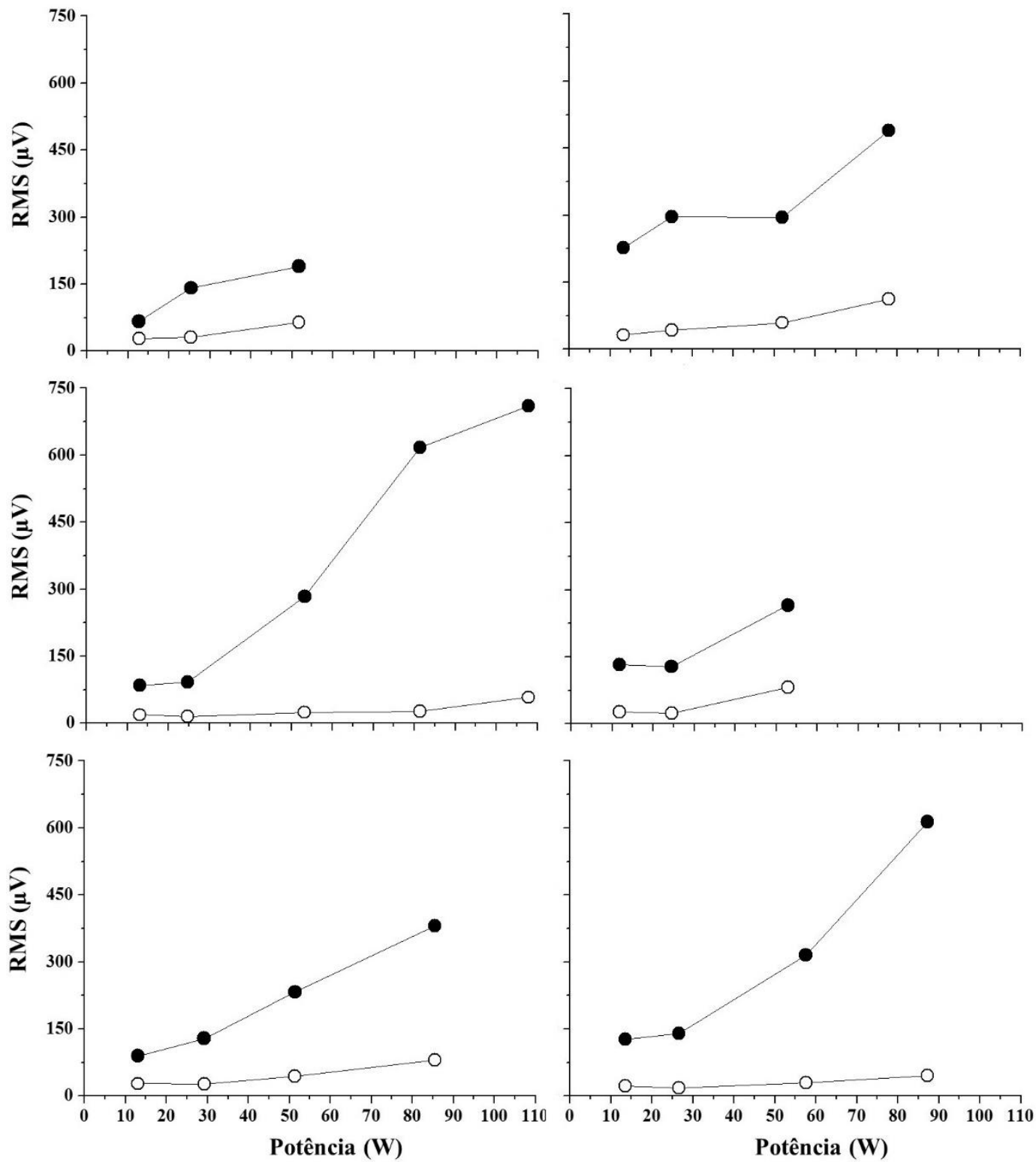

Figura 49. Comportamentos individuais da root mean square (RMS) observada nos músculos vastus lateralis (símbolos fechados) e biceps femoris (símbolos abertos), durante o esforço progressivo até a exaustão. 


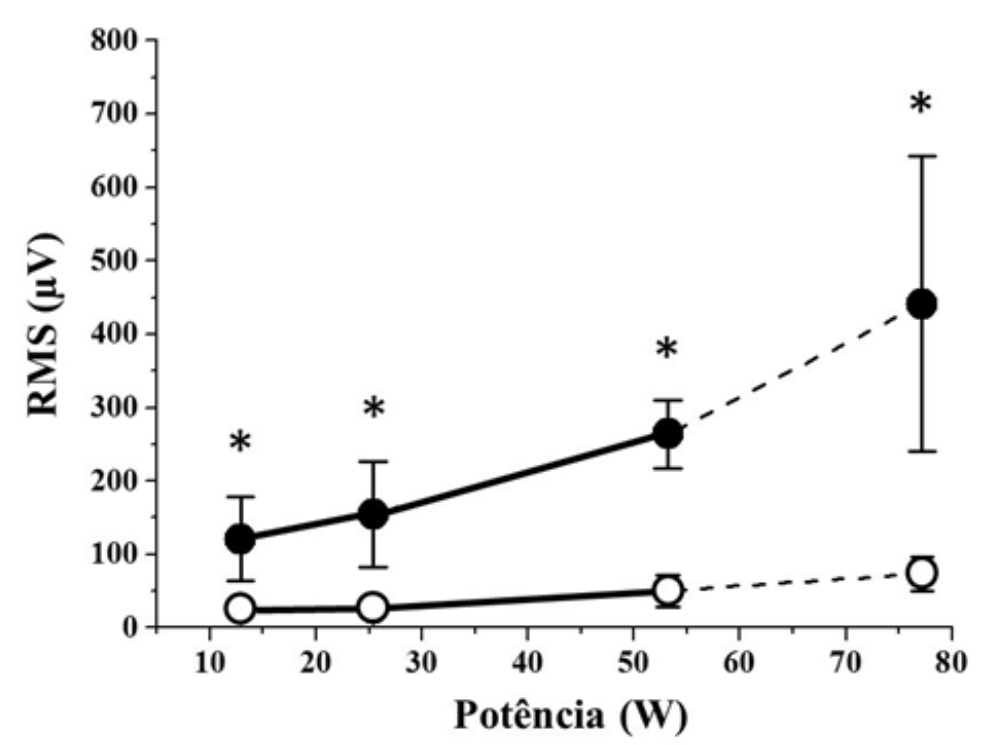

Figura 50. Comportamento médio da root mean square (RMS) observada nos músculos vastus lateralis (símbolos fechados) e biceps femoris (símbolos abertos), durante o esforço progressivo até a exaustão $(77,2 \pm 21,7 \mathrm{~W})$. *

Diferença significativa entre os músculos ( $p$-valor $<0,05)$;

Estudos anteriores evidenciaram elevadas ativações dos músculos anteriores da coxa (e.g., Vastus lateralis, Vastus medialis e Rectus femoris) sem significativas alterações em outros músculos tanto do membro inferior (e.g., Tibialis anterior, Biceps femoris, Gluteous medius e Gastrocnemius) como daqueles responsáveis pela estabilização do tronco (e.g., Rectus abdominus e Erector spinae) [51]. Ainda neste estudo, os autores confirmaram uma ativação similar entre os diferentes vastos do quadríceps, demonstrando que toda a musculatura anterior da coxa é utilizada durante as extensões dinâmicas. Os resultados do presente estudo demonstraram que o protótipo construído pelo nosso grupo de estudos também foi eficaz para isolar a musculatura anterior da coxa, principalmente pelas ativações significativamente superiores do Vastus lateralis em relação as respostas do Biceps Femoris. De fato, como demonstrado na Figura 48, alguma ativação do Biceps fomoris ocorre, principalmente nos estágios próximos à exaustão. Estes resultados, embora em menores magnitudes, também foram observados por Andersen et al. [51] nos últimos estágios de esforços progressivos e durante uma contração isométrica máxima. Assim, a utilização dos posteriores de coxa parece ser uma 
estratégia comumente utilizada na tentativa de manter a cadência em esforços de alta intensidade, o que pode ser amenizado por meio de mais sessões de familiarização. Entretanto, assim como apontado por Andersen et al. [51], é plausível supor que a maior parte do trabalho envolvido durante o exercício é advindo do quadríceps. Além disso, considerando que as respostas apresentadas na Figura 48 são relativas as 10 ultimas extensões, esta estratégia deve ocorrer apenas nos últimos instantes do exercício, tendo uma pequena influência sobre os resultados.

\section{Experimento 2 - Comparação entre testes incrementais}

\section{Contextualização}

A proposta do projeto principal é investigar as respostas relacionadas à fadiga em esforços com B-Glic, realizados em diferentes intensidades de exercício. Para isso, serão realizados esforços exaustivos nos domínios de intensidade moderado, pesado e severo. Os limites entre os domínios de intensidade podem ser determinados por meio de testes incrementais, utilizando os limiares metabólicos e as respostas do $\dot{\mathrm{V}}_{2}$.

Embora a realização de testes incrementais seja um procedimento comum em estudos utilizando a extensão dinâmica de joelhos, as respostas fisiológicas obtidas por diferentes protocolos ainda não foram investigadas. Além disso, de acordo com o nosso conhecimento, nenhum estudo investigou os limiares metabólicos neste modelo de exercício, o que pode influenciar diretamente o delineamento experimental do nosso projeto principal. Neste contexto, precisamos determinar qual é o protocolo incremental mais efetivo para a determinação dos limiares metabólicos e da intensidade relacionada ao consumo de oxigênio pico (iVंO 2 PICO).

Com base nas necessidades metodológicas evidenciadas anteriormente, o objetivo deste 
experimento foi comparar as respostas fisiológicas obtidas em dois testes incrementais, os quais foram diferentes na intensidade inicial, na duração do estágio e na magnitude dos incrementos.

\section{Materiais e Método}

Seis indivíduos do sexo masculino (Média \pm DP; idade: 27,50 \pm 4,02 anos, estatura: 183,2 $\pm 8,1 \mathrm{~cm}$ e peso corporal: $98,2 \pm 11,5 \mathrm{Kg}$ ) participaram voluntariamente do experimento. Todos os indivíduos foram informados sobre os riscos e benefícios envolvidos durante os esforços, concordando por escrito com as suas participações.

Previamente a realização dos experimentos, todos os participantes realizaram uma sessão de familiarização, onde foram realizados esforços com diferentes intensidades e durações (e.g. 2 - 7 min). O posicionamento dos participantes no ergômetro de extensão dinâmica de joelhos foi padronizado nesta sessão de familiarização, o que foi mantido durante todos os esforços.

Durante os experimentos, os participantes realizaram dois testes incrementais (TI-1 e TI2), os quais foram separados por um intervalo mínimo de $72 \mathrm{~h}$. Os participantes foram instruídos a manter suas dietas habituais e a evitar o consumo de cafeína e de outros estimulantes nas três horas que antecederam aos testes.

Os protocolos aplicados durante os testes incrementais estão demonstrados na Tabela 2. O TI-1 iniciou com uma intensidade mais elevada, teve estágios mais longos e maiores incrementos entre os estágios. Em ambos os protocolos a cadência foi mantida em 60 rpm e o primeiro estágio teve duração de 7 min para aquecimento. Estas cargas foram aplicadas utilizando o sistema de frenagem mecânica, calibrado conforme descrito no capítulo anterior. 
Tabela 2. Protocolos aplicados durante os dois testes incrementais investigados (TI).

\begin{tabular}{ccc}
\hline & TI-1 & TI-2 \\
\hline Intensidade inicial (W) & 26 & 13 \\
Incrementos (W) & 26 & 13 \\
Duração dos estágios (s) & 120 & 60 \\
Cadência (rpm) & 60 & 60 \\
\hline
\end{tabular}

Durante todo o esforço as variáveis ventilatórias foram obtidas a cada respiração. O analisador de gases (K4b2 Quark; Cosmed®, Roma, Itália) foi calibrado conforme as especificações do fabricante, utilizando concentrações de gases conhecidas e uma seringa de calibração (3L; Hans-Rudolph, Kansas City, Estados Unidos). A FC foi determinada a cada respiração por meio de interface com o software do analisador de gases. Após a retirada dos pontos discrepantes, as variáveis fisiológicas foram interpoladas individualmente em função do tempo de exercício, sendo obtidos os valores a cada segundo. As médias dos últimos $10 \mathrm{~s}$ de exercício foram utilizadas para as análises. Os valores médios obtidos nos últimos $30 \mathrm{~s}$ de cada estágio foram utilizados durante as análises. A percepção subjetiva de esforço (PSE) foi determinada ao final de cada estágio por meio da escala de 10 pontos [122], a qual todos os participantes eram familiarizados. Previamente ao teste e nos minutos 1, 3, 5 e 7 após a exaustão, as concentrações sanguíneas de lactato ([La-]) foram determinadas, seguindo os procedimentos necessários para as posteriores análises (YSI-2300; Yellow Springs Instruments $^{\circledR}$, Ohio, USA).

O $\dot{\mathrm{V}}$ 2PICO foi assumido como os valores observados no último estágio completo. A iVंO 2 PICo foi assumida como a intensidade do último estágio completo ou foi ajustada conforme 
a equação proposta por Kuipers et al. [123], nos casos em que a exaustão ocorreu durante os estágios (Equação 6).

Equação 6.

$\mathrm{iV}_{2 \mathrm{PICO}}(\mathrm{W})=\mathrm{EC}+\left(\mathrm{TP} \cdot \mathrm{DE}^{-1} \cdot \mathrm{IN}\right)$

Onde: EC é a potência no último estágio completo (W), TP é o tempo de permanência no último estágio incompleto (s), DE é a duração do estágio e IN é o incremento aplicado a cada estágio.

Os limiares metabólicos foram determinados por meio das trocas gasosas, utilizando modelos mistos de análise (i.e., interação entre duas ou mais variáveis ventilatórias). O limiar ventilatório $(\mathrm{LV})$ foi assumido como a intensidade onde foram observados aumentos contínuos tanto do equivalente ventilatório do $\dot{\mathrm{V}} \mathrm{O}_{2}\left(\dot{\mathrm{V} E} / \dot{\mathrm{V}}_{2}\right)$ como da fração expirada de $\mathrm{O}_{2}$, sem um concomitante aumento do equivalente ventilatório da produção de $\mathrm{CO}_{2}\left(\dot{\mathrm{VE}} / \mathrm{CO}_{2}\right)$ [124]. $\mathrm{O}$ ponto de compensação respiratória (PCR), foi assumido como a intensidade de exercício correspondente ao aumento do $\dot{\mathrm{V}} / \mathrm{CO}_{2}$ concomitante ao declínio da fração expirada de $\mathrm{CO}_{2}$ [125]. Os limiares metabólicos foram determinados por dois pesquisadores conhecedores dos fenômenos. Nos casos em que houveram discordâncias, um terceiro pesquisador realizou as análises e a moda entre eles foi utilizada. Ambos os limiares metabólicos foram expressos em relação aos seus valores de intensidade (W), FC (bpm), PSE (u.a.) e $\dot{\mathrm{VO}} 2\left(\mathrm{~mL} \cdot \mathrm{Kg}^{-1} \cdot \mathrm{min}^{-1}\right)$.

As contribuições energéticas relacionadas aos metabolismos anaeróbio alático (AnAl), anaeróbio lático (AnLa) e aeróbio (Ae), foram determinadas para os dois testes incrementais. A contribuição AnAl foi estimada por meio da fase rápida do consumo excessivo de oxigênio, observado nos sete primeiros minutos após a exaustão. A contribuição AnLa foi determinada por meio do acumulo das $\left[\mathrm{La}^{-}\right]$(i.e. diferença entre os valores pico e as concentrações de repouso), assumindo-se um equivalente metabólico de $3 \mathrm{~mL} \mathrm{O} \cdot \mathrm{Kg}^{-1}$, para cada $1 \mathrm{mM}$ de 
lactato acumulado. A contribuição Ae foi assumida como a área abaixo do $\dot{\mathrm{VO}}_{2}$ observado durante o teste incremental. Com isso, o custo energético total foi calculado pela soma das contribuições AnAl, AnLa e Ae. Todos os cálculos para a determinação das contribuições energéticas foram realizados em software específico (GEDAE-LaB; São Paulo; Brasil), validado para este proposito [126].

Para análises dos dados, utilizamos procedimentos não-paramétricos, evitando os erros de uniformidade relacionados ao baixo número de participantes. Assim a estatística descritiva foi apresentada em mediana (intervalo interquartil). As respostas fisiológicas observadas nos dois testes incrementais foram comparadas por meio do teste Wilcoxon e relacionadas por meio do coeficiente de Spearman. Todas as análises foram realizadas com o auxílio do pacote estatístico SPSS versão (SPSS Inc, Illinois, Estados Unidos), e em todos os casos o nível de significância foi fixado em $p$-valor $<0,05$.

\section{Resultados e inferências}

Embora os testes incrementais apresentem diferenças em seus protocolos, a duração do esforço foi similar (TI-1 = 8,00 (2,50) $\mathrm{min} ; \mathrm{T} 2=8,00(3,50) \mathrm{min} ;$-valor $=0,10)$. Os valores pico observados ao final dos testes incrementais estão apresentados na Tabela 3. O quociente respiratório $(\mathrm{QR})$ foi significativamente maior ao final do TI-2, o que não foi observado para a FC e as $\left[\mathrm{La}^{-}\right]$. Os valores de PSE apresentaram uma tendência para a diferenciação entre os dois testes, evidenciando valores ligeiramente superiores em TI-2. Apenas os valores de QR foram correlacionados entre os testes incrementais $(\mathrm{r}=0,93 ; p$-valor $=0,001)$. 
Tabela 3. Valores pico das variáveis fisiológicas obtidas durante os diferentes testes incrementais.

\begin{tabular}{cccc}
\hline & TI-1 & TI-2 & p-valor \\
\hline QR (u.a.) & $1,14(0,36)$ & $1,29(0,28)$ & $0,03 *$ \\
PSE (u.a.) & $8,50(1,50)$ & $9,50(1,00)$ & 0,06 \\
FC (bpm) & $136,90(41,65)$ & $144,18(40,29)$ & 0,75 \\
FC (\% da máxima) & $70,4(21,06)$ & $73,50(22,21)$ & 0,75 \\
{$\left[\mathrm{La}^{-}\right](\mathrm{mM})$} & $8,67(4,03)$ & $9,31(3,16)$ & 0,60
\end{tabular}

TI-1: primeiro teste incremental com incrementos de $26 \mathrm{~W}$ a cada $2 \mathrm{~min}$; TI-2: e no segundo teste incremental com incrementos de $13 \mathrm{~W}$ a cada minuto; QR: quociente respiratório; PSE: percepção subjetiva de esforço; FC: frequência cardíaca apresentada em bpm e em percentual dos valores máximos teóricos (i.e. 220 - idade); [ $\left.\mathrm{La}^{-}\right]$: concentrações sanguíneas de lactato.

Embora os valores de QR, PSE e [ $\left.\mathrm{La}^{-}\right]$tenham apresentado valores próximos aos esperados, os valores de FC foram inferiores aos tipicamente observados durante testes incrementais (i.e. > 90\% da FC máxima predita). Neste contexto, a predominância do consumo de carboidratos e a percepção relacionada a esforços máximos, parecem não sofrer influências da massa muscular envolvida durante o esforço. Além disso, embora as concentrações de lactato sejam relacionadas apenas ao trabalho realizado pelo quadríceps, seus valores podem ser comparados a outros modelos de esforço, principalmente pela menor remoção deste metabólito pelos outros grupamentos que não são ativados durante o exercício [127].

A Figura 51 demonstra o comportamento individual do $\dot{\mathrm{V}}_{2}$ durante os testes incrementais. A Figura 52 demonstra os valores de $\dot{\mathrm{V}} \mathrm{O}_{2 \mathrm{PICO}}$ e $\mathrm{i} \dot{\mathrm{V}} \mathrm{O}_{2 \mathrm{PICO}}$ observados nos dois 
testes incrementais. Embora o $\dot{\mathrm{V}} \mathrm{O}_{2 \mathrm{PICO}}$ não tenha sido diferente, os valores desta variável não foram correlacionados entre os testes incrementais $(\mathrm{r}=0,45 ; p$-valor $=0,33) . \mathrm{A}$ iV $\dot{\mathrm{VO}}_{2 \mathrm{PICO}}$ foi significativamente maior no TI-2 ( $p$-valor $=0,03)$, o que foi acompanhado por correlações não significantes entre os testes $(r=0,54 ;$-valor $=0,27)$.

Estes resultados concordam com outros estudos que observaram diferenças significativas

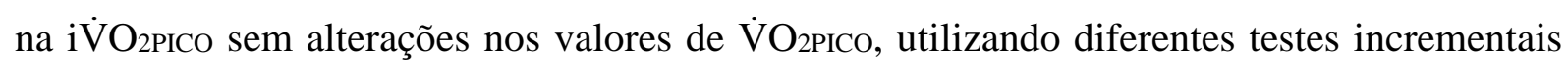
[128-131]. Embora o $\dot{\mathrm{VO}} 2$ apresente um comportamento convencional durante os testes (i.e., aumento linear), pode-se observar que a utilização da extensão dinâmica de joelhos induziu

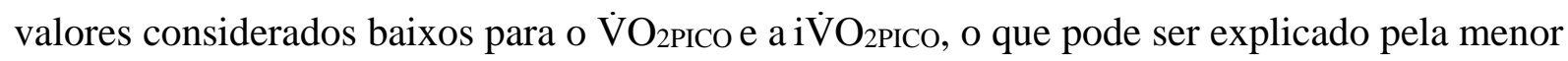
quantidade de músculos utilizados durante o exercício [132]. Estes valores relacionados ao VंO 2 PICo também são observados em termos absolutos [TI-1: 2,43 $(0,50) \mathrm{L} \cdot \mathrm{min}^{-1}$; TI-2: 1,92 $\left.(1,16) \mathrm{L} \cdot \mathrm{min}^{-1}\right]$, indicando que os critérios tipicamente utilizados para a confirmação dos valores máximos de $\dot{\mathrm{V} O}$, não podem ser aplicados neste modelo de exercício. 

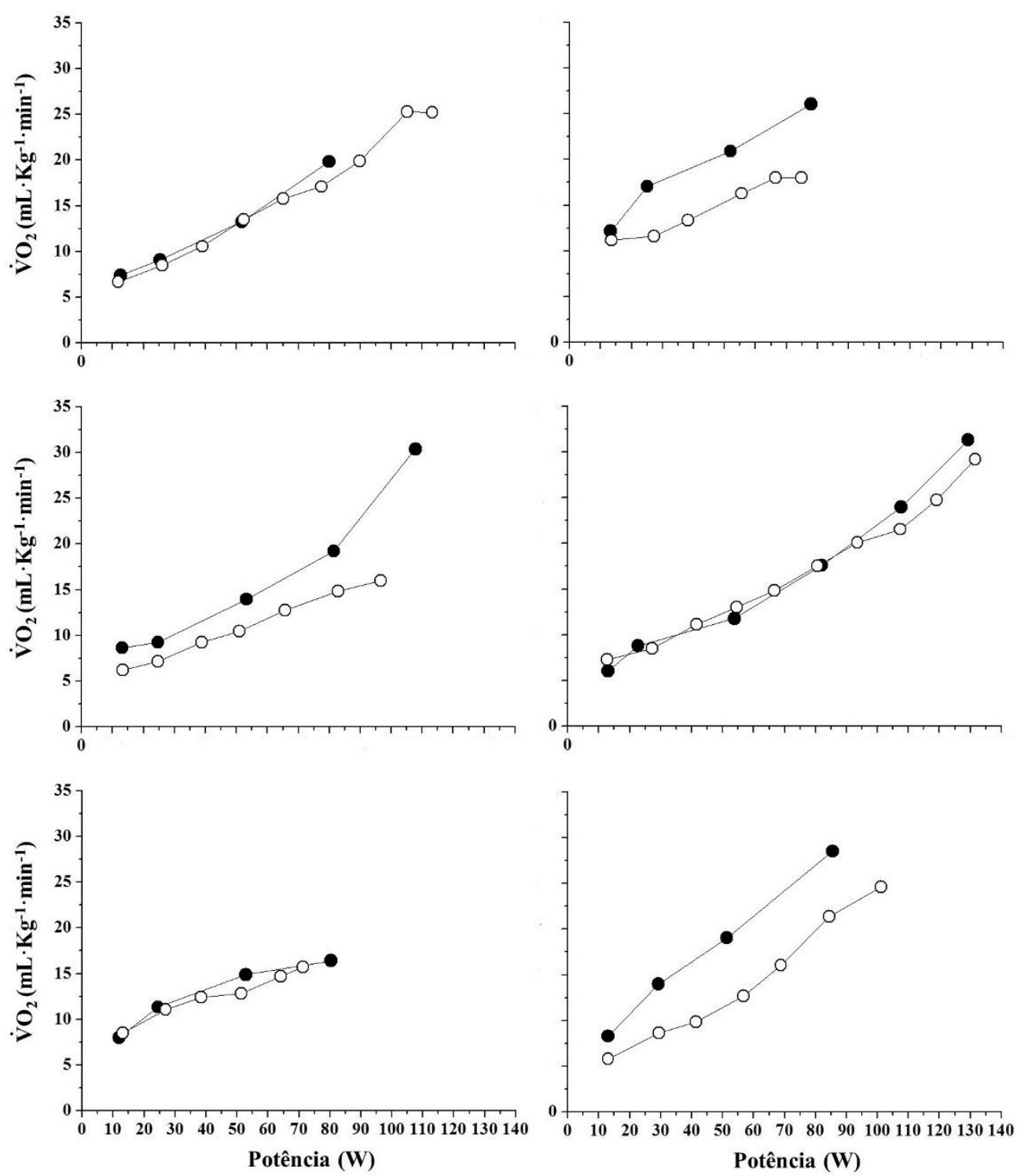

Figura 51. Comportamento individual do consumo de oxigênio $\left(\dot{\mathrm{V}}_{2}\right)$ durante os testes incrementais (TI-1: incrementos de $26 \mathrm{~W}$ a cada $2 \mathrm{~min}$; TI-2; incrementos de $13 \mathrm{~W}$ a cada minuto). A maior potência demonstrada é equivalente ao último estágio completo. 

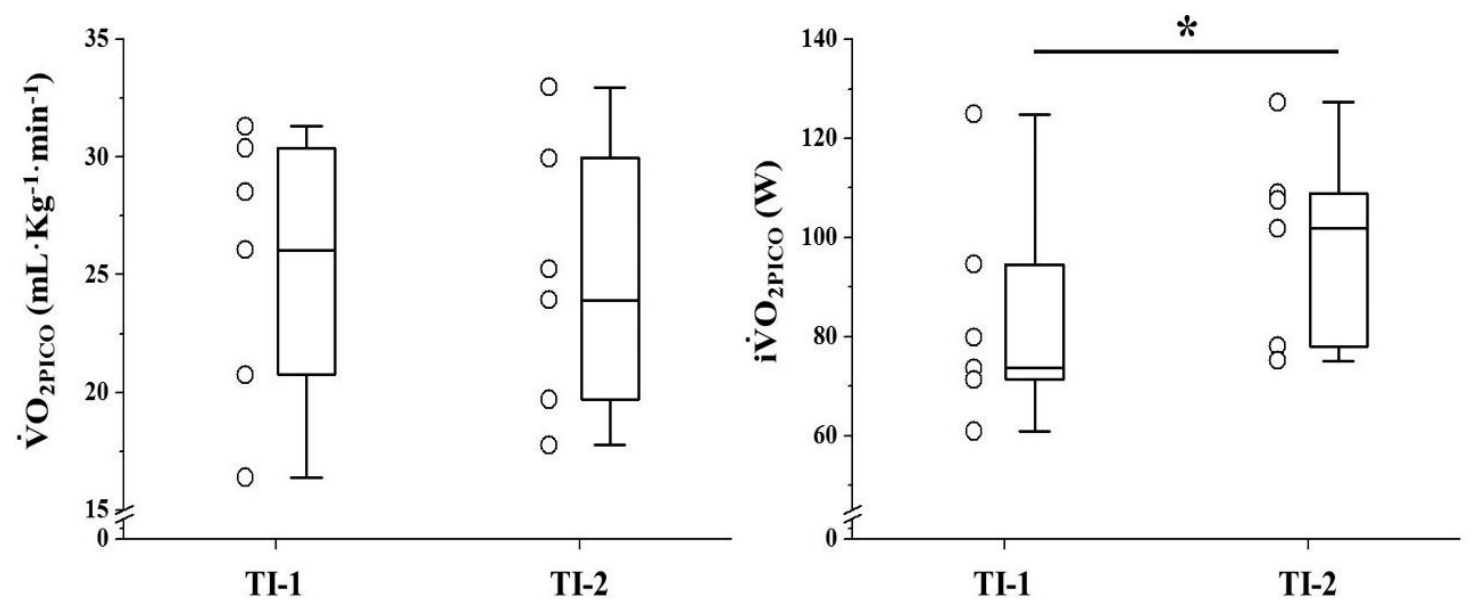

Figura 52. Valores do consumo de oxigênio pico ( $\dot{\mathrm{V}}_{2 \mathrm{PICO}}$ ) e da intensidade relacionada a este índice (iVंO 2 PICO), obtidos nos testes incrementais (TI-1: incrementos de $26 \mathrm{~W}$ a cada 2 min; TI-2; incrementos de $13 \mathrm{~W}$ a cada minuto). Os símbolos vazios representam os valores individuais. * Diferença significativa entre os testes $(p$-valor $<0,05)$.

A Tabela 4 demonstra a frequência de determinação dos limiares, conforme a intensidade onde estes índices foram observados. Durante o TI-1, foi possível a determinação do LV em apenas dois participantes. Diferentemente, todos os participantes demonstraram a ocorrência do LV durante o TI-2 [Intensidade: $34,12 \mathrm{~W}$ ou 30,04 $(17,20) \% \dot{\mathrm{V} O}_{2 \mathrm{PICO}}$; FC: $90,87(17,02)$ bpm; PSE: 2,00 (1,25) u.a.; $\dot{\mathrm{V} O} 2$ : $\left.10,79(3,14) \mathrm{mL} \cdot \mathrm{Kg}^{-1} \cdot \mathrm{min}^{-1}\right]$. A determinação do PCR foi possível para todos os participantes, demonstrando valores similares independentemente do teste incremental aplicado ou da forma de expressão (Tabela 5). Entretanto, não foram observadas correlações significativas entre os valores de PCR observados nos testes incrementais ( $\mathrm{r}<0,71 ;$-valor $>0,11)$. Estes resultados demonstram que o TI-2 foi o protocolo mais efetivo para a determinação dos limiares metabólicos (i.e., LV e PCR determinados em todos os sujeitos). 
Tabela 4. Frequência absoluta de determinação dos limiares metabólicos nos diferentes testes incrementais, conforme a intensidade de ocorrência.

\begin{tabular}{cccccc}
\hline & \multicolumn{3}{c}{ TI-1 } & & \multicolumn{3}{c}{ TI-2 } \\
\cline { 2 - 3 } \cline { 5 - 6 } Classes $(\mathrm{W})$ & LV & PCR & & LV & PCR \\
$0-26$ & 1 & 2 & & 2 & 0 \\
$26,1-52$ & 0 & 0 & & 4 & 0 \\
$52,1-\mid 78$ & 1 & 3 & & 0 & 4 \\
$78,1-\mid 104$ & 0 & 0 & & 0 & 2 \\
$104,1-130$ & 0 & 1 & & 0 & 0 \\
Soma & 2 & 6 & 6 & 6
\end{tabular}

TI-1: primeiro teste incremental com incrementos de $26 \mathrm{~W}$ a cada 2 min; TI-2: e no segundo teste incremental com incrementos de $13 \mathrm{~W}$ a cada minuto; LV: limiar ventilatório; PCR: ponto de compensação respiratório.

Tabela 5. Valores correspondentes ao ponto de compensação respiratório (PCR), determinado nos dois testes incrementais.

\begin{tabular}{|c|c|c|c|}
\hline & TI-1 & TI-2 & p-valor \\
\hline Intensidade $(\mathrm{W})$ & $51,66(41,72)$ & $61,20(36,17)$ & 0,17 \\
\hline Intensidade $\left(\% \mathrm{i} \dot{\mathrm{VO}}_{2 \mathrm{PICO}}\right)$ & $63,44(51,11)$ & $69,78(14,10)$ & 0,46 \\
\hline $\mathrm{FC}(\mathrm{bpm})$ & $115,70(30,10)$ & $117,28(11,68)$ & 0,17 \\
\hline PSE (u.a) & $4,00(2,50)$ & $6,50(2,00)$ & 0,11 \\
\hline$\dot{\mathrm{V}} \mathrm{O}_{2}\left(\mathrm{~mL} \cdot \mathrm{Kg}^{-1} \cdot \mathrm{min}^{-1}\right)$ & $16,49(10,91)$ & $15,53(5,11)$ & 0,60 \\
\hline
\end{tabular}

TI-1: primeiro teste incremental com incrementos de $26 \mathrm{~W}$ a cada 2 min; TI-2: e no segundo 
teste incremental com incrementos de $13 \mathrm{~W}$ a cada minuto; $i \dot{\mathrm{VO}}_{2 \mathrm{PICO}}$ : intensidade relacionada ao consumo de oxigênio pico; FC: frequência cardíaca; PSE: percepção subjetiva de esforço; $\dot{\mathrm{V}} \mathrm{O}_{2}$ : consumo de oxigênio.

O custo energético total não foi diferente entre os testes incrementais ( $p$-valor $=0,92)$. Como esperado, o metabolismo aeróbio foi predominante durante ambos os testes incrementais, sem diferenças significativas entre os protocolos $(p$-valor $=0,46)$. Embora a contribuição AnAl tenha sido similar entre os testes ( $p$-valor $=0,60)$, a contribuição AnLa foi significativamente superior no TI-2 ( $p$-valor $=0,03)$. Os valores relacionados as diferentes contribuições energéticas estão demonstradas na Figura 53.
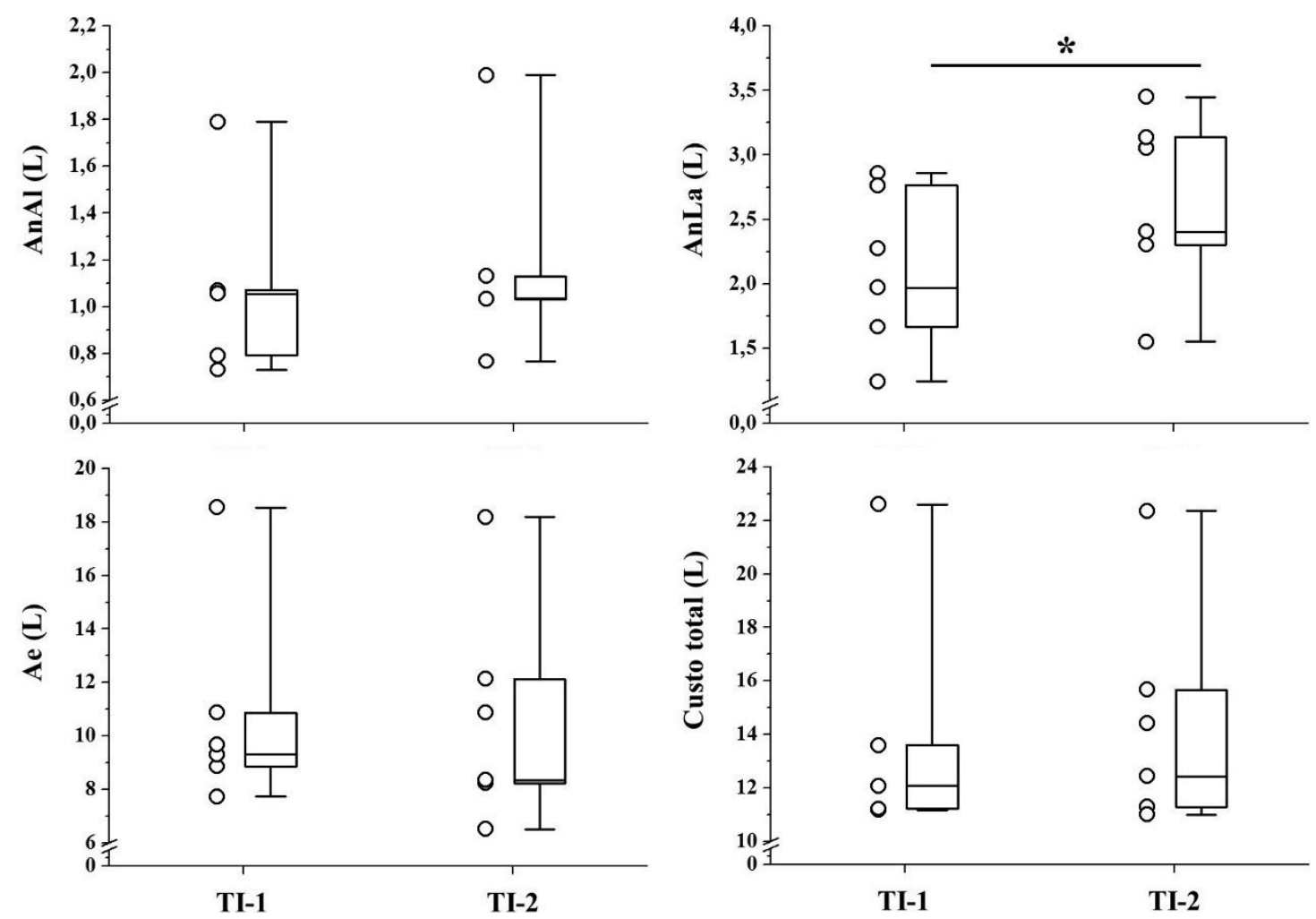

Figura 53. Contribuições energéticas observadas durante o primeiro (TI-1; incrementos de 26 $\mathrm{W}$ a cada $2 \mathrm{~min}$ ) e segundo (TI-2; incrementos de $13 \mathrm{~W}$ a cada minuto) testes incrementais. Os símbolos vazios representam os valores individuais. AnAl: contribuição anaeróbia alática; AnLa: contribuição anaeróbia lática; Ce: contribuição aeróbia; Custo total: soma de todas as 
contribuições; * Diferença significativa entre os testes $(p$-valor $<0,05)$.

Em resumo, os resultados deste experimento demonstram que, embora as durações dos testes incrementais tenham sido similares, o TI-2 foi o protocolo mais efetivo para a determinação das variáveis fisiológicas. Especificamente, a utilização do TI-2 permitiu a determinação do LV e do PCR em todos os participantes, o que será fundamental para a determinação dos domínios fisiológicos e, consequentemente, prescrição das intensidades durante o projeto principal. Estes resultados podem ser explicados pelo fato de que a intensidade inicial do TI-1 foi superior ao LV dos participantes, impossibilitando a determinação deste limiar metabólico durante o protocolo.

No TI-2, os valores de $\mathrm{i} \dot{\mathrm{V}}_{2 \mathrm{PICO}}$ foram superiores aos observados no TI-1, o que pode ser explicado pelos menores incrementos aplicados entre os estágios deste protocolo, resultando em uma menor sobrecarga entre os estágios, o que possibilitou a realização de mais esforços acima do PCR e, consequentemente, aumentou as contribuições AnLa. Com base nesses achados, o TI-2 será aplicado em todas as próximas etapas do projeto principal.

\section{Experimento 3 - Respostas fisiológicas em esforços constantes}

\section{Contextualização}

De fato, a utilização do modelo de extensão dinâmica de joelhos até o presente projeto era uma novidade em nossa rotina laboratorial. A partir dos experimentos descritos acima, observamos que tivemos sucesso em isolar a musculatura anterior de coxa e que o melhor modelo de teste incremental seria o de estágios curtos com pequenos incrementos (i.e., 13 $\left.\mathrm{W} \cdot \mathrm{min}^{-1}\right)$. Entretanto, considerando a pequena massa muscular envolvida e a pouca sinergia muscular observada durante o exercício, o esforço realizado de maneira constante poderia 
apresentar uma menor tolerância em relação a outros modelos de exercício. Esta característica inerente a utilização da extensão dinâmica de joelhos poderia comprometer a aplicabilidade do projeto principal, principalmente quando consideramos esforços até a exaustão voluntária, caso da investigação da fadiga nos diferentes domínios fisiológicos.

Desse modo, realizamos um pequeno experimento para investigar a tolerância a esforços constantes, realizados tanto em intensidades submáximas (i.e., < $\mathrm{iVO}_{2 \mathrm{PICO}}$ ) como em intensidades supramáximas (i.e., $110 \%$ da $\mathrm{iVO}_{2 \mathrm{PICO}}$ ), estes últimos realizados até a exaustão voluntária.

\section{Materiais e Método}

Oito participantes (idade: $26 \pm 4$ anos; estatura: $180,3 \pm 8,5 \mathrm{~cm}$; peso corporal: $88,3 \pm$ $14,3 \mathrm{Kg}$ ), foram submetidos a um teste incremental, idêntico ao TI-2 aplicado no experimento anterior, e a cinco esforços constantes com intensidades relativas a 50,60, 70, 80, e $110 \%$ da iVO2PICo. Os esforços submáximos tiveram duração de 7 min e o supramáximo foi realizado até a exaustão voluntária ou até a incapacidade do participante em manter a cadência por mais de 10 s (i.e., < $60 \mathrm{rpm}$ ). Adicionalmente, dois participantes realizaram um esforço constante a 90\% da $\mathrm{iVO}_{2 \mathrm{PICO}}$, possibilitando a investigação sobre a tolerância nesta intensidade. O tempo de esforço ou o até a exaustão (Tlim) foi registrado durante todo o esforço (Timex®, modelo 85103).

Todos os participantes foram previamente familiarizados ao modelo de extensão dinâmica de joelhos. Durante todos os esforços $\mathrm{o} \mathrm{VO}_{2}$ foi monitorado a cada respiração, conforme descrito nos experimentos anteriores (K4b2 Quark; Cosmed®, Roma, Itália). A PSE foi determinada ao final de cada esforço utilizando a escala de 10 pontos, conforme descrito anteriormente. 
Após confirmada a normalidade dos dados por meio do teste de Shapiro-Wilk, os dados foram apresentados em média e desvio padrão. Os valores de $\mathrm{VO}_{2}$ e PSE observados ao final dos esforços foi comparado por meio do teste de Wilcoxon, adotando-se um nível de significância de $p$-valor $<0,05$.

\section{Resultados e inferências}

A Figura 54 demonstra os valores de $\mathrm{VO}_{2}$ observados nos quatro esforços submáximos. O comportamento do $\mathrm{VO}_{2}$ durante o esforço supramáximo está demonstrado na Figura 55. O Tlim a $110 \%$ da $\mathrm{iVO}_{2 \mathrm{PICO}}$ foi de 2,5 \pm 0,8 min, apresentando uma grande variação entre os participantes (valores entre 1,6 e 4,3 min; coeficiente de variação $=31,9 \%$ ). Todos os participantes suportaram o tempo pré-determinado nas intensidades submáximas, embora tenham relatado um grande desconforto ao final do esforço em $80 \%$ da $\mathrm{iVO}_{2 \mathrm{PICO}}$ (PSE entre 8 e 9).

A Figura 56 demonstra os valores médios de $\mathrm{VO}_{2}$ e PSE, observados ao final dos diferentes esforços. $\mathrm{O} \mathrm{VO}_{2}$ observado no esforço a $50 \%$ da $\mathrm{iVO}_{2 \mathrm{PICO}}$ foi significativamente inferior a todas as outras intensidades de esforço constante ( $p$-valor $<0,02)$. Entretanto, não foram observadas diferenças significativas entre os esforços de 70, 80 e $110 \%$ da iVO 2 PICO ( $p$ valor > 0,09), indicando possivelmente uma estabilização no $\mathrm{VO}_{2 \mathrm{PICO}}$ destas intensidades. A PSE observada no esforço supramáximo foi significativamente superior aos valores observados nos outros esforços ( $p$-valor < 0,01). Dentre os esforços submáximos, a PSE observada após o esforço a $80 \%$ da iVO 2 PICO apresentou valor significativamente superior $(p$-valor $<0,01)$.

Apenas um dos participantes suportou o esforço a $90 \%$ da iVO $2 \mathrm{PICO}$, mas para isso vários feedbacks do tempo restante foram realizados e a cadência oscilou consideravelmente. O Tlim do outro participante foi de 4,2 min. A PSE relatada por ambos os participantes foi de 10 u.a.. 
O comportamento do $\mathrm{VO}_{2}$ durante o esforço a $90 \%$ da iVO 2 PICO está demonstrado na Figura 57. Ambos os participantes atingiram valores muito próximos do $\mathrm{VO}_{2 \mathrm{PICO}}$ ao final do esforço a $90 \%$ da iVO 2 PICO (i.e., diferenças de 1,7 e $1,4 \mathrm{~mL} \cdot \mathrm{Kg}^{-1} \cdot \mathrm{min}^{-1}$ ).

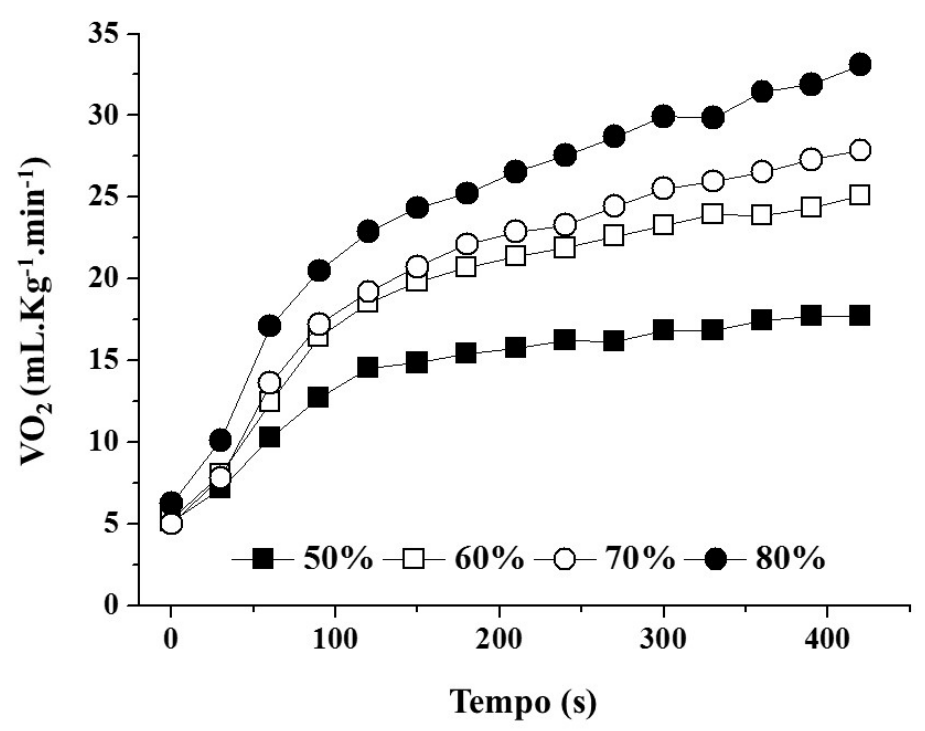

omitido para melhor visualização do comportamento.

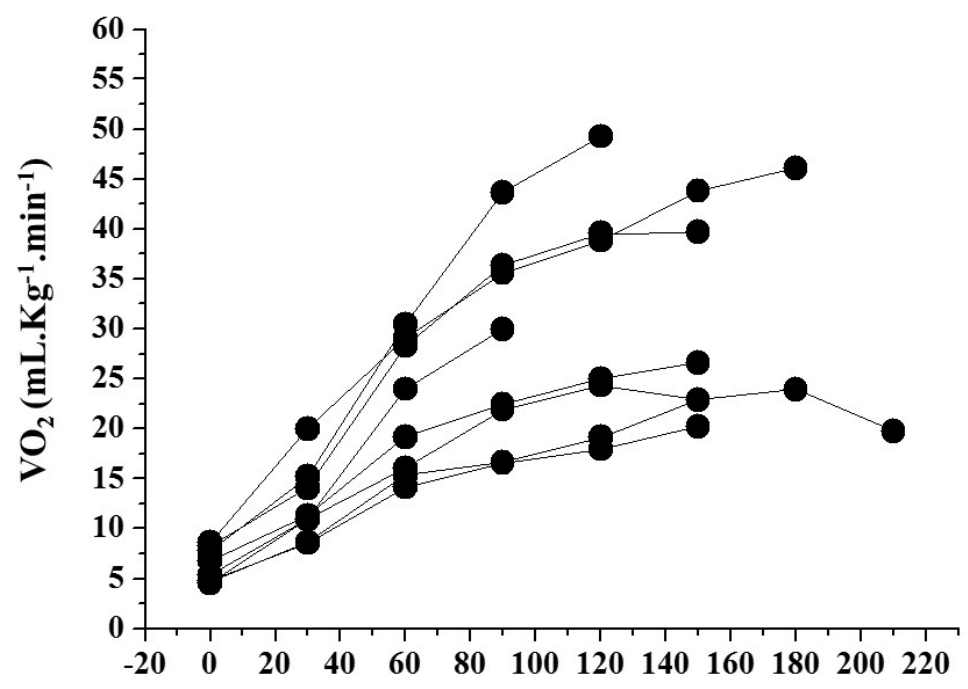

Tempo (s)
Figura 54. Comportamento do consumo de oxigênio $\left(\mathrm{VO}_{2}\right)$ durante os esforços realizados abaixo da máxima intensidade atingida no teste incremental (iVO 2 PICO). Os $\quad$ Símbolos representam a média a cada $30 \mathrm{~s}$. O desvio padrão dos pontos foi

Figura 55. Comportamento individual do consumo de oxigênio $\left(\mathrm{VO}_{2}\right)$ durante o esforço realizado acima da máxima intensidade atingida no teste incremental $\left(\mathrm{iVO}_{2 \mathrm{PICO}}\right)$ (i.e., supramáximo). Os símbolos representam a média a cada $30 \mathrm{~s}$. 


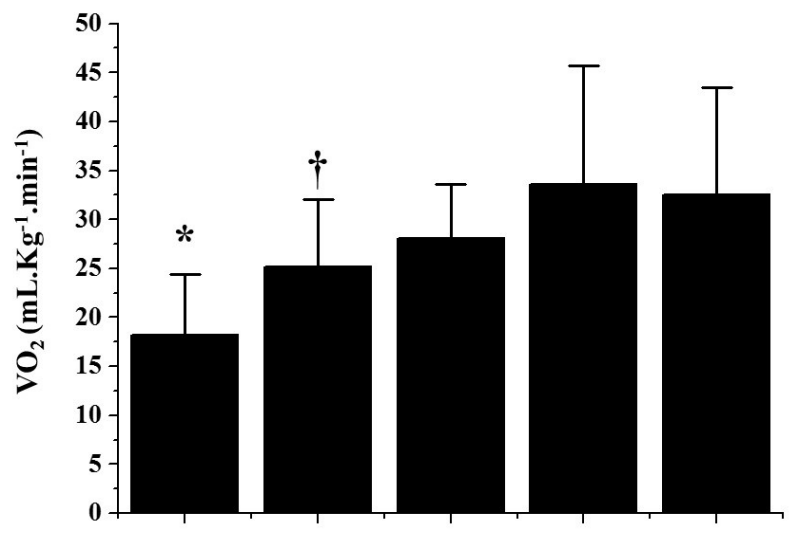

Figura 56. Valores médios e desvio padrão

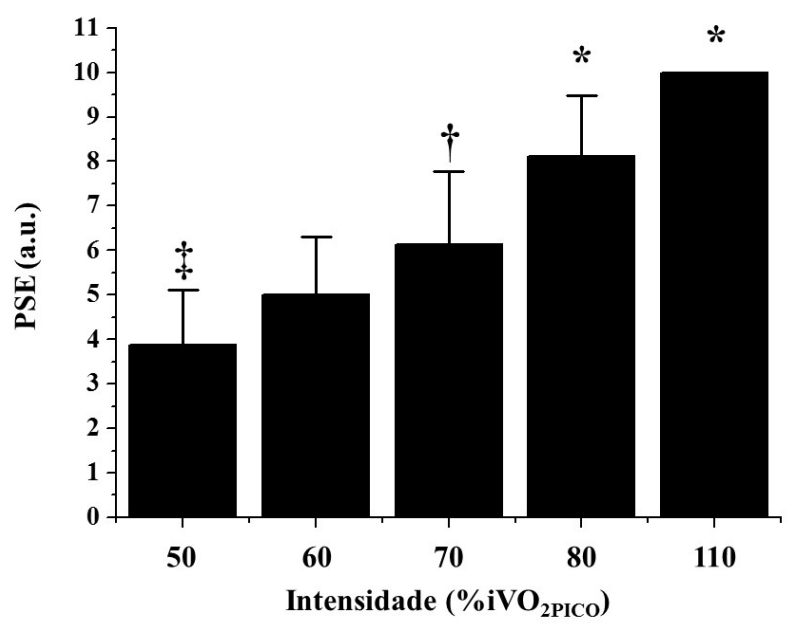

do consumo de oxigênio $\left(\mathrm{VO}_{2}\right)$ e da percepção subjetiva de esforço (PSE) observados ao final dos esforços constantes realizados abaixo e acima da máxima intensidade atingida no teste incremental (iVO2PICO). *: Diferença significativa com relação a todas as outras intensidades ( $p$ valor $<0,05)$; $\uparrow$ : Diferença significativa com relação as intensidades de 80 e $110 \%$ da $\mathrm{iVO}_{2 \mathrm{PICO}}(p$-valor $<0,05) ;+$ Diferença significativa com relação as intensidades de $70,80$ e $110 \%$ da iVO 2 PICO ( $p$-valor $<0,05)$.

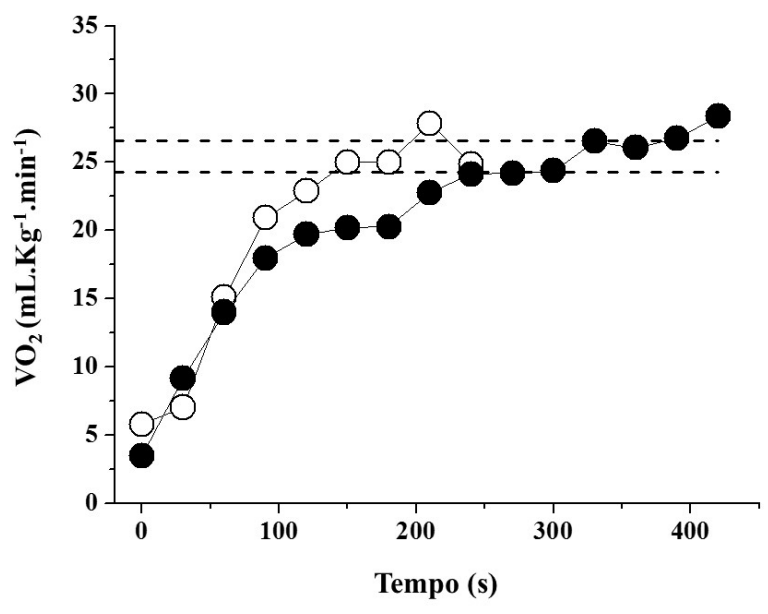

Figura 57. Comportamento do consumo de oxigênio $\left(\mathrm{VO}_{2}\right)$ demonstrado por dois participantes durante um esforço a $90 \%$ da máxima intensidade atingida durante o teste incremental (iVO2PICO). Os pontos representam as médias a cada $30 \mathrm{~s}$ e as linhas tracejadas representam os valores individuais de $\mathrm{VO}_{2}$ pico, observados em um esforço supramáximo. 
Em conjunto os resultados deste experimento demonstram que o exercício constante realizado por meio da extensão dinâmica de joelhos foi tolerado pelos participantes, pelo menos em intensidades equivalentes ou abaixo de $80 \%$ da $\mathrm{iVO}_{2 \mathrm{PICO}}$, apresentando resultados comparáveis aos frequentemente observados em outros modelos de exercício. Talvez os resultados que mais chamaram atenção neste experimento foram os valores similares do $\mathrm{VO}_{2}$ observados entre as intensidades de 70, 80 e $110 \%$ da iVO 2 PICO. Neste contexto, em exercícios como a corrida a intensidade de $70 \%$ da $\mathrm{iVO}_{2 \mathrm{PICO}}$ está inserida no domínio de intensidade pesado [133], onde o $\mathrm{VO}_{2}$ apresenta uma estabilização abaixo dos valores máximos [134] - no presente caso valores pico, considerando-se a limitada massa muscular envolvida no exercício. Pode-se especular que o $\mathrm{VO}_{2}$ nesta intensidade poderia apresentar uma estabilização tardia (5 - 15 min), mas os valores observados a $70 \%$ da $\mathrm{iVO}_{2 \mathrm{PICO}}$ foram comparados com aqueles observados em um exercício exaustivo, o qual teoricamente é suficiente para atingir os valores de $\mathrm{VO}_{2 \mathrm{PICO}}$ [134]. Assim, considerando a proximidade com os valores de $\mathrm{VO}_{2 \mathrm{PICO}}$, é plausível questionar se um esforço contínuo a $70 \%$ da $\mathrm{iVO}_{2}$ PICo seria facilmente tolerado por um longo período.

No projeto principal, baseando-se na literatura existente sobre a depleção do glicogênio utilizando a extensão dinâmica de joelhos $[10,11]$, nós propusemos a utilização de um exercício

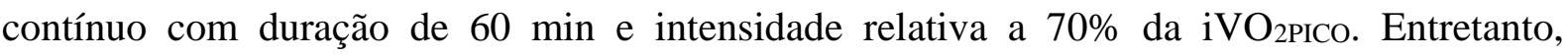
considerando os achados deste pequeno experimento, consideramos a realização de mais estudos, principalmente para a investigação sobre a tolerância do esforço utilizado para a depleção do glicogênio, fator primordial para responder à pergunta central do projeto principal.

Além disso, outra observação importante do presente experimento foi a intolerância evidenciada na intensidade correspondente a $90 \%$ da iVO 2 PICO. Este resultado possui especial significado para os experimentos do projeto principal, pois o esforço no domínio severo seria 
realizado em intensidades próximas a $90 \%$ da iVO 2 PICO. Considerando tal intolerância, outras estratégias devem ser traçadas para a investigação da fadiga neste domínio fisiológico.

\section{Considerações}

Tendo em vista a pergunta central do presente projeto de pesquisa e os desafios metodológicos impostos para responde-la, ficou evidente a necessidade da extensão dinâmica de joelhos como modelo de exercício, principalmente pela agilidade na obtenção das variáveis relacionadas a fadiga central e periférica - com a aplicação das técnicas de TI e EMT - no mesmo segmento muscular onde o B-Glic foi induzido. Assim, considerando que nosso grupo de pesquisa teve apenas um breve contato com este modelo de exercício durante intercâmbios realizados na Dinamarca (i.e., Prof. Dr. Marcelo Papoti - 2012; Prof. Dr. Eduardo Zapaterra Campos - 2014; Prof. Dr. Ricardo Augusto Barbieri - 2015), foram necessárias padronizações e investigações sobre as respostas fisiológicas oriundas deste exercício, as quais foram apresentadas acima.

Considerando os achados apresentados até aqui, podemos inferir que tivemos sucesso em isolar a musculatura anterior de coxa durante o esforço e que a maioria das respostas fisiológicas, embora em menor magnitude, assemelham-se aquelas observadas em outros modelos de exercício. Entretanto, o último experimento demonstrou que possivelmente o esforço contínuo a 70\% da iVO2PICO seja pouco tolerável em exercícios prolongados (i.e., > 30 min), o que inviabiliza a aplicação do modelo proposto inicialmente para a depleção do glicogênio muscular. Desse modo, embora tenhamos proposto traçar a curva de recuperação das variáveis fisiológicas após a depleção do glicogênio muscular (i.e., $1^{\text {o }}$ procedimento do delineamento inicial), decidimos focar no esforço de depleção propriamente dito. Além disso, a grande dificuldade dos participantes em tolerar o esforço a $90 \%$ da $\mathrm{iVO}_{2 \mathrm{PICO}}$, demonstra a 
necessidade de traçarmos novas estratégias para a investigação da fadiga no domínio de intensidade severo, aumentando o tempo de esforço nestas condições.

Desse modo, o próximo capitulo descreve algumas tentativas para a padronização do esforço de depleção (i.e., intensidade, volume e densidade). Além disso, embora não tenham sido monitoradas todas as variáveis propostas no experimento 1 do delineamento original, também testamos se $12 \mathrm{~h}$ de intervalo seriam suficientes entre o esforço de depleção e o esforço de interesse nos domínios de intensidade. 


\section{IV - A PADRONIZAÇÃO DO ESFORÇO PARA DEPLEÇÃO DO GLICOGÊNIO MUSCULAR (voltar ao Capítulo 2) (Voltar ao Capítulo 4)}

\section{Primeira tentativa -O protocolo inicialmente proposto}

\section{Contextualização}

Além da investigação sobre a tolerância ao exercício realizado para a depleção do glicogênio muscular, todas as tecnologias envolvidas na obtenção das variáveis fisiológicas e de desempenho também deveriam ser testadas, aprimoradas e adaptadas ao contexto do presente estudo. Neste contexto, a principal ferramenta que foi testada nesta primeira tentativa foi o sistema de aquisição dos sinais de força, o qual foi descrito e calibrado conforme os procedimentos do será descrito no documento principal. A diferença primordial nesta primeira tentativa foi a aquisição dos dados por meio de uma rotina em ambiente LabView (National Instruments ${ }^{\mathrm{TM}}$ LabVIEW). A principal vantagem de utilizar esta plataforma para aquisição dos dados de força, foi a possibilidade de demonstrar ao participante seu desempenho em tempo real.

\section{Modelo de depleção e variáveis coletadas}

Como primeira tentativa, buscamos aplicar o protocolo proposto no projeto principal, o qual foi embasado em estudos prévios (i.e., $60 \mathrm{~min}$ a $70 \%$ da $\mathrm{iVO}_{2 \mathrm{PICO}}$ ). Para isso, 10 esforços de 6 min foram aplicados, sendo separados por um período de até dois minutos. Entre os esforços, a técnica de TI foi aplicada, conforme será descrito no documento principal. Nesta etapa, um participante realizou todos os procedimentos (idade: 31 anos; estatura: 183,0 cm; peso corporal: 113,0 Kg). Caso o participante não fosse capaz de sustentar a cadência préestabelecida (i.e., 60 rpm), a carga foi diminuída até o reestabelecimento desta frequência. 


\section{Resultados e inferências}

A utilização do sistema LabView para aquisição da força mostrou-se ineficaz, principalmente pelo tempo necessário para gerar o arquivo de resultados (i.e., $\approx 2,5 \mathrm{~min}$ ), o que somado aos procedimentos da TI, elevou demasiadamente a recuperação entre cada esforço de 5 min. Além disso, os sinais de força correspondentes ao sétimo esforço não foram gravados, fato relacionado ao processamento dos sinais. Como nossos resultados prévios haviam indicado, para que o volume total de esforço fosse completado, uma diminuição na intensidade foi necessária ao longo do protocolo de depleção. O comportamento da força média obtida pelas células de carga nas botas e a potência gerada ao longo do esforço de depleção, estão apresentadas na Figura 58.
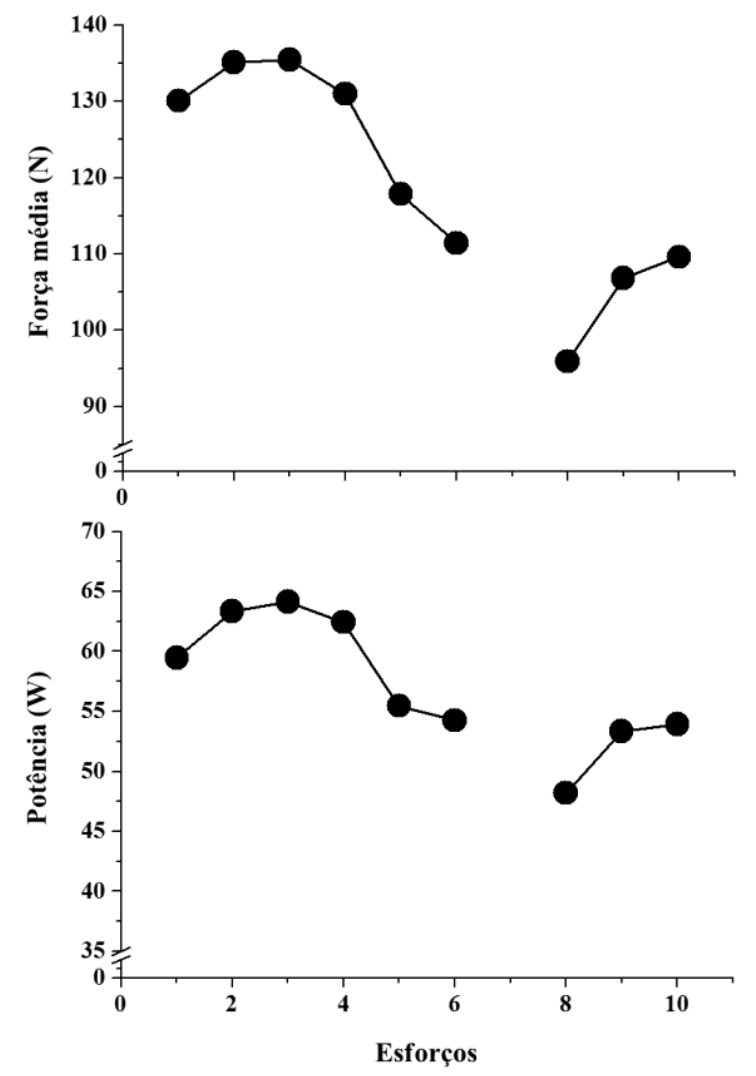

Figura 58. Comportamento da força média observada nas botas do ergômetro e da potência gerada ao longo do esforço de depleção (10 x 6 min, com intensidade inicial correspondente a $70 \%$ da máxima atingida no teste incremental). Os dados do sétimo esforço foram comprometidos no momento da aquisição.

O tempo entre o final do exercício e a realização da contração isométrica máxima foi 
inferior a $15 \mathrm{~s}$. A técnica de TI demonstrou que a força pico diminuiu ao longo do esforço de depleção $(\approx 9,99 \mathrm{Kg})$, assim como os valores de TS $(\approx 0,96 \mathrm{Kg})$ e TP $(\approx 3,5 \mathrm{Kg})$. Entretanto, a AV apresentou uma variação máxima de 5\%. O comportamento dos parâmetros provenientes da técnica de TI ao longo do esforço de depleção, estão apresentados na Figura 59. A diminuição da TS concomitantemente a queda dos valores de TP e manutenção da AV, indicam que a fadiga ocasionada por este esforço teve origem periférica [4].

Em conjunto estes resultados demonstram que o esforço de depleção foi bem suportado pelo indivíduo, embora poucos ajustes na intensidade tenham sido necessários. Além disso, o esforço no ergômetro proporcionou intervalos muito curtos entre o exercício e a aplicação da técnica de TI, possibilitando a investigação da fadiga envolvida neste esforço de uma maneira bastante robusta. Entretanto, até este experimento não sabíamos a magnitude da depleção do glicogênio muscular induzida por este esforço. 

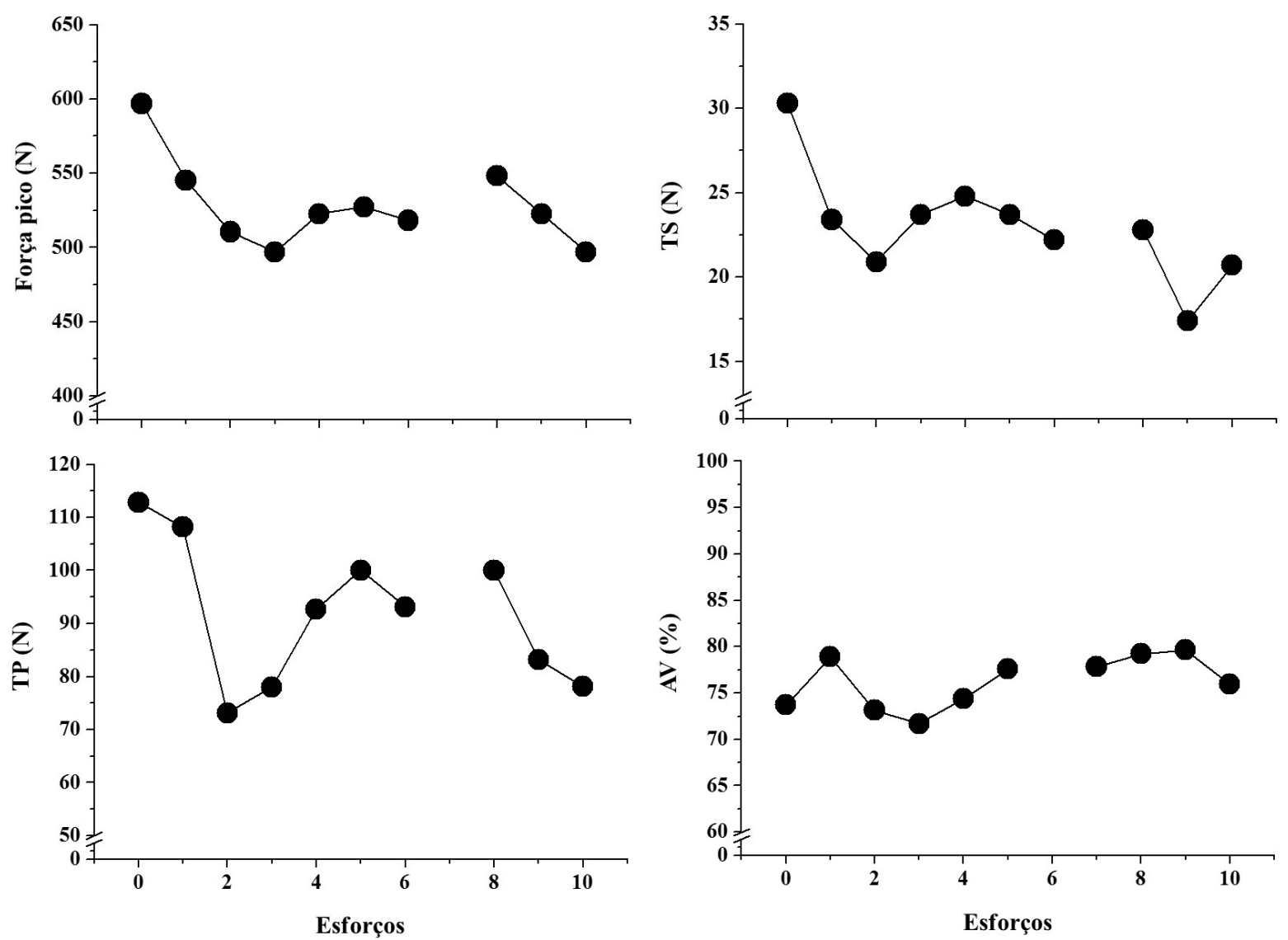

Figura 59. Comportamento dos parâmetros obtidos por meio da técnica de Twitch Interpolation observados ao longo do esforço de depleção. Os dados do sétimo esforço foram comprometidos no momento da aquisição. TS: força evocada com o estímulo elétrico durante a contração isométrica máxima; TP: força evocada com o estímulo elétrico aplicado no músculo relaxado; $\mathrm{AV}$ : ativação voluntária obtida por meio desta técnica.

\section{Segunda tentativa - Estimativa do glicogênio, depleção das fibras tipo II e 12 h de}

\section{recuperação}

\section{Contextualização}

A partir dos resultados da primeira tentativa, observamos que i) a intensidade de $70 \%$ da iVO 2 PICO pode ser utilizada para o esforço de depleção, desde que ajustes mínimos na carga sejam realizados para que o volume proposto seja cumprido, ii) a utilização da plataforma 
LabView® não foi efetiva para aquisição dos dados de força durante o exercício, e iii) a utilização do ergômetro proporcionou rapidez para aplicação da técnica de TI, aumentando a robustez dos dados. Entretanto, considerando que outras técnicas além da TI devem ser aplicadas durante as pausas entre os esforços, possibilitando a avaliação de aspectos metabólicos, estes períodos de avaliação devem ser mais bem padronizados. Neste sentido, na segunda tentativa optamos por adicionar as estimativas do conteúdo de glicogênio muscular aos períodos de intervalo.

Outro aspecto que nos chamou atenção, foram os comentários realizados pelo Prof. Dr. Nikolai Baastrup Nordsborg acerca do nosso projeto. O referido professor tem ampla experiência no estudo dos diferentes aspectos relacionados a fadiga muscular, sendo o diretor do departamento de Nutrição, Exercício e Esportes do Instituto August Krogh, na Dinamarca. Durante sua visita ao nosso laboratório em novembro de 2016, o referido professor chamou atenção para o esforço de depleção, o qual não contemplava, a princípio, a depleção das fibras musculares do tipo II. Esta observação foi de extrema importância, principalmente quando nos preocuparmos com a fadiga no domínio severo. Desse modo, nesta segunda tentativa, mantivemos a intensidade do exercício em $70 \%$ da $\mathrm{iVO}_{2 \mathrm{PICO}}$, realizando ajustes quando o participante fosse incapaz de manter a cadência em $60 \mathrm{rpm}$, mas diminuímos o volume deste esforço para 10 esforços de 5 min. Além disso, conforme observado por estudos anteriores [10], foram adicionados esforços de alta intensidade ao final do esforço de depleção.

Por fim, após 12 h do esforço de depleção aplicado nesta tentativa, realizamos também o modelo de exercício no domínio severo. Conforme observado nos experimentos preliminares descritos acima, a intensidade de exercício neste domínio foi pouco tolerada (90\% da iVO2PICO; Tlim < 10 min). Esta condição representa uma limitação, principalmente por impossibilitar a avaliação da fadiga durante o esforço, em pontos intermediários entre o início do exercício e o 
momento da exaustão. Desse modo, propusemos a realização de um de um esforço intermitente para a investigação da fadiga durante o exercício no domínio severo, na tentativa de traçarmos estes importantes pontos intermediários de avaliação.

\section{Modelo de depleção, variáveis coletadas e esforço no domínio severo}

Dois indivíduos participaram deste experimento (idade: $27 \pm 4$ anos; estatura 188,5 $\pm 3,5$ cm; peso corporal: $87,0 \pm 1,4 \mathrm{Kg}$ ), os quais apresentavam familiarização prévia com o modelo de extensão dinâmica de joelhos. O esforço de depleção foi composto de 10 esforços de 5 min com intensidade inicial equivalente a $70 \%$ da $\mathrm{iVO}_{2 \mathrm{PICO}}$, seguidos de esforços de um minuto com intensidade inicial de $120 \%$ da $\mathrm{iVO}_{2 \mathrm{PICO}}$. Estes esforços de alta intensidade foram separados por três minutos de intervalo passivo e foram realizados até a exaustão voluntária. Em todos os esforços ajustes na intensidade foram realizados para a manutenção do volume do exercício proposto (i.e., 5 min para os esforços a $70 \%$ da iVO 2 PICo e 1 min para os esforços a $120 \%$ da iVO $2 \mathrm{PICO}$ ), conforme descrito na tentativa anterior. Após 12 h de repouso (i.e., pernoite), os participantes foram submetidos a seis esforços de um minuto com intensidade correspondente a $120 \%$ da $\mathrm{iVO}_{2 \mathrm{PICO}}$, os quais também foram separados por 3 min de recuperação passiva. Durante o período de repouso, os participantes receberam quatro litros de solução contendo 400 g de maltodextrina $\left(\approx 4,5 \mathrm{~g} \cdot \mathrm{Kg}^{-1}\right)$, e foram instruídos a ingerir alimentos com baixos conteúdos de carboidratos (i.e., 4,6 g que compuseram 7,6\% dos macronutrientes ingeridos).

Tanto durante o esforço de depleção como durante o esforço no domínio severo, a técnica de TI foi aplicada e o conteúdo de glicogênio foi estimado por meio de imagens de ultrassom, procedimentos descritos no item 2.3.. Todos os procedimentos para aquisição dos sinais de força foram realizados em ambiente Matlab®, utilizando aplicativos e rotinas desenvolvidas especificamente para este propósito. A Figura 60 esquematiza os diferentes esforços e os 
momentos de avaliação aplicados neste experimento.

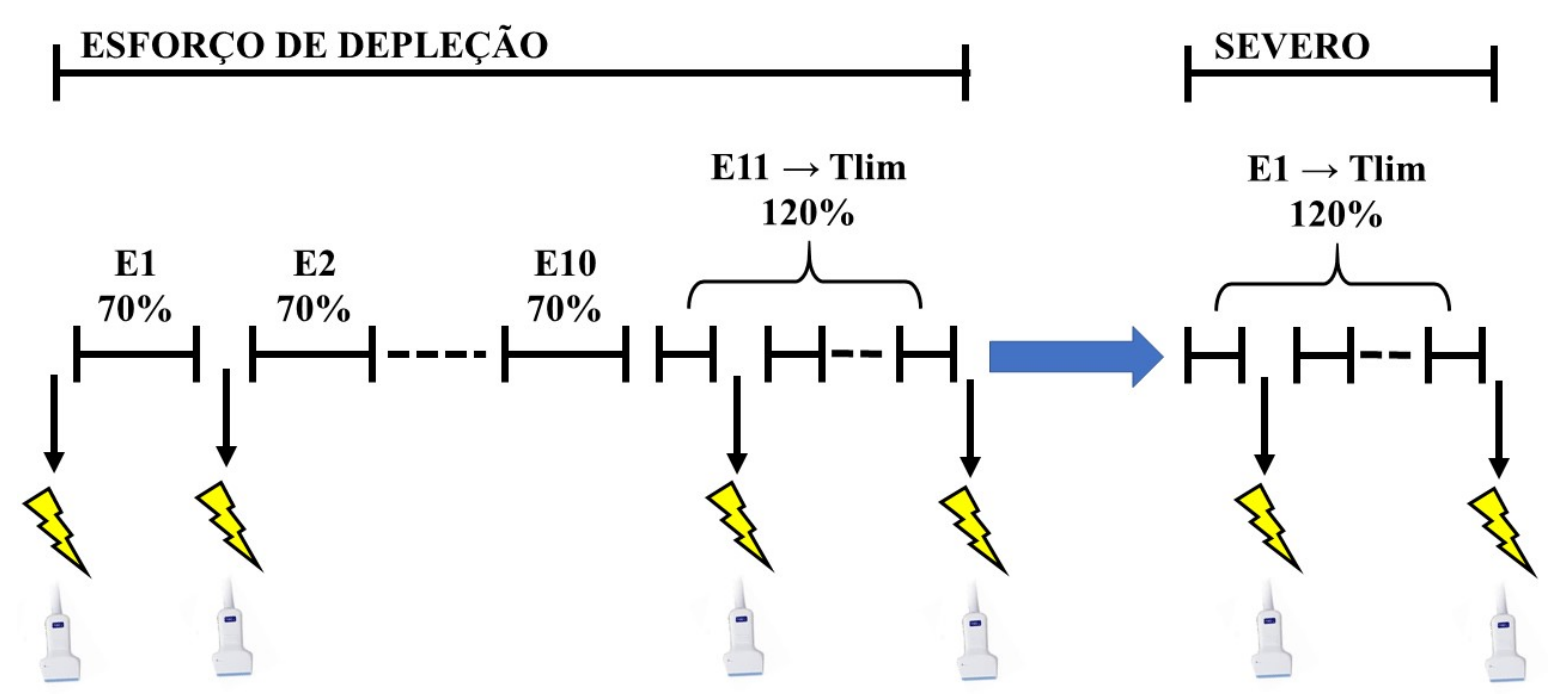

Figura 60. Delineamento do esforço de depleção e do esforço de interesse no domínio severo.

Os percentuais representam a intensidade em relação a máxima atingida durante um teste incremental ( $\mathrm{iVO}_{2 \mathrm{PICO}}$ ). Os esforços realizados a $70 \%$ da $\mathrm{iVO}_{2 \mathrm{PICO}}$ tiveram duração de 5 min e os esforços com intensidade de $120 \%$ da $\mathrm{iVO}_{2 \mathrm{PICO}}$ foram realizados por um minuto.

avaliação dos processos centrais e periféricos relacionados a fadiga; ${ }^{-}$: estimativa do conteúdo de glicogênio por meio de imagens de ultrassom; $\Rightarrow \Rightarrow$ : intervalo de recuperação com solução contendo maltodextrina.

\section{Resultados e inferências}

A utilização da plataforma Matlab® diminuiu significativamente o tempo necessário para o processamento e armazenamento dos dados de força. Desse modo, mesmo com a técnica de TI e as estimativas do conteúdo de glicogênio sendo aplicadas a cada intervalo, o período de recuperação reduziu de 5 min para aproximadamente $2,5 \mathrm{~min}$.

O comportamento da força média observada nas botas e da potência desenvolvida ao 
longo do esforço de depleção estão apresentadas na Figura 61. Como observado durante a primeira tentativa, um declínio na força média e na potência foi observado ao longo do esforço a $70 \%$ da $\mathrm{iVO}_{2 \mathrm{PICO}}(\approx 41 \mathrm{~N}$ e $17,3 \mathrm{~W})$. O número máximo de repetições nos esforços de alta intensidade realizados ao final da depleção foi de dois esforços (Figura 61).

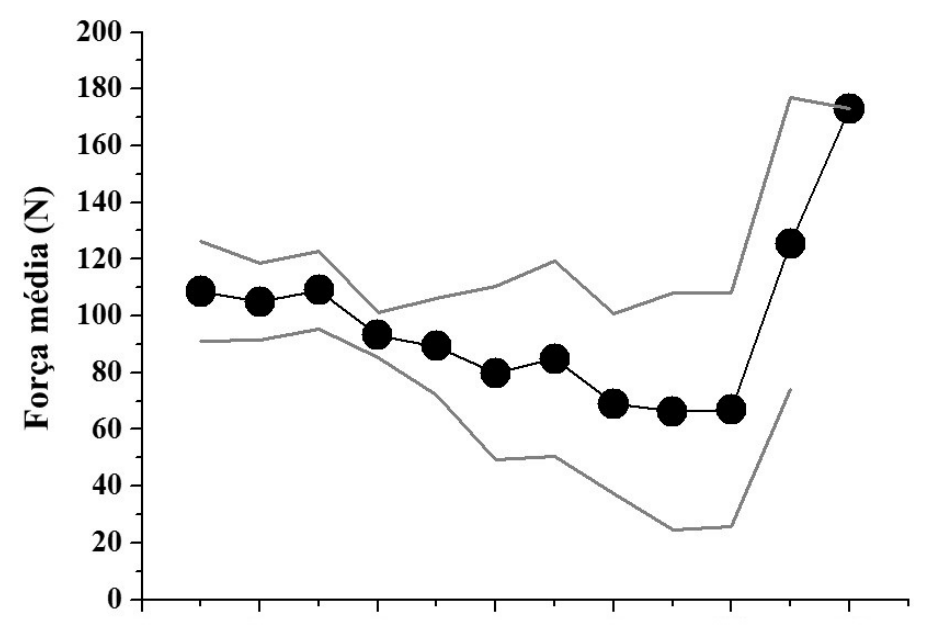

Figura 61. Comportamento da força média observada nas botas do ergômetro e a potência desenvolvida ao longo do esforço de depleção.

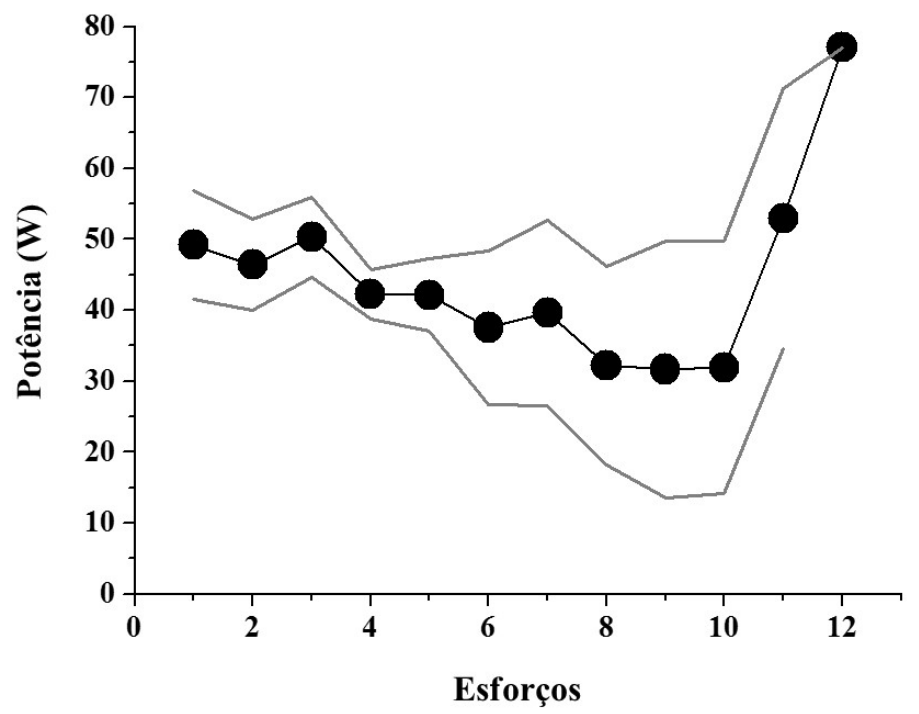

O tempo de intervalo obtido neste experimento também foi suficiente para que a estimativa do glicogênio muscular pudesse ser realizada, principalmente porque a utilização do ergômetro de extensão permitiu o posicionamento do equipamento ultrassom próximo ao 
avaliado (Figura 62). Basicamente, para que esta estimativa ocorra, várias imagens são realizadas do músculo Rectus femoris, utilizando a forma de aquisição em modo B. Estas imagens são imediatamente enviadas para análise no software da MuscleSound ${ }^{\circledR}$, onde o processamento ocorre e o score de glicogênio é gerado (Figura 63). Como no mínimo três imagens são necessárias para este processo, durante as avaliações nós realizamos de 8 a 12 aquisições. Este procedimento é necessário pois imagens com baixa qualidade - com problemas na definição e/ou alinhamento do musculo ao centro da imagem - são automaticamente excluídas pelo software. No presente experimento, 292 imagens foram realizadas, sendo 205 efetivamente utilizadas para as análises. Os scores de glicogênio apresentaram uma queda ao longo do esforço de depleção de 55 e $65 \%$ para os dois participantes. O comportamento destes scores ao longo do esforço de depleção, está apresentado na Figura 64.

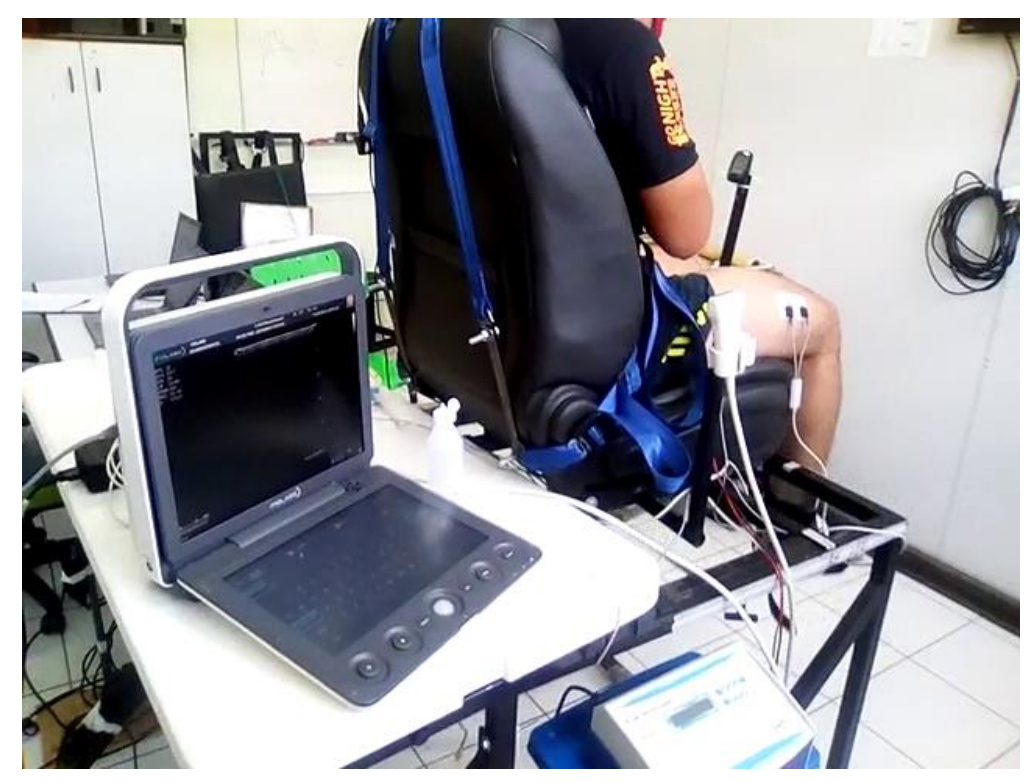

Figura 62. Posicionamento do equipamento de ultrassom próximo ao avaliado, o que diminuiu consideravelmente o tempo necessário para aquisição das imagens. 


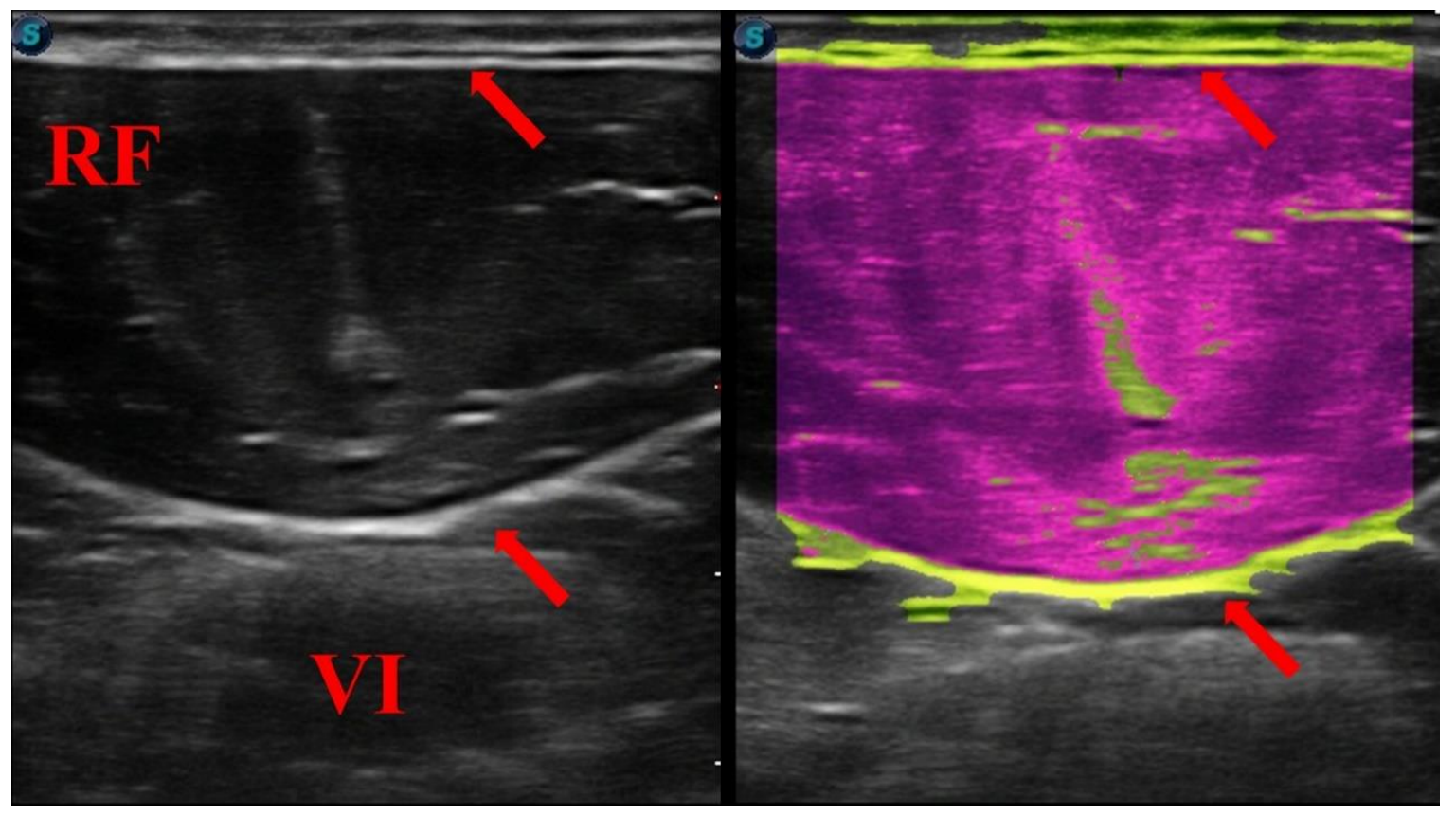

Figura 63. Imagens de ultrassom obtidas no presente experimento do músculo Rectus femoris (RF). As flechas representam as fáscias superior e inferior, as quais devem aparecer na imagem de maneira contínua e horizontal, delimitando o músculo de interesse e o Vastus Intermédius. A imagem direita foi obtida no software MuscleSound ${ }^{\circledR}$, onde a área roxa foi a efetivamente analisada para os conteúdos de glicogênio e as áreas verdes representam tecidos não utilizados para as análises (e.g., fáscias e tecidos conectivos).

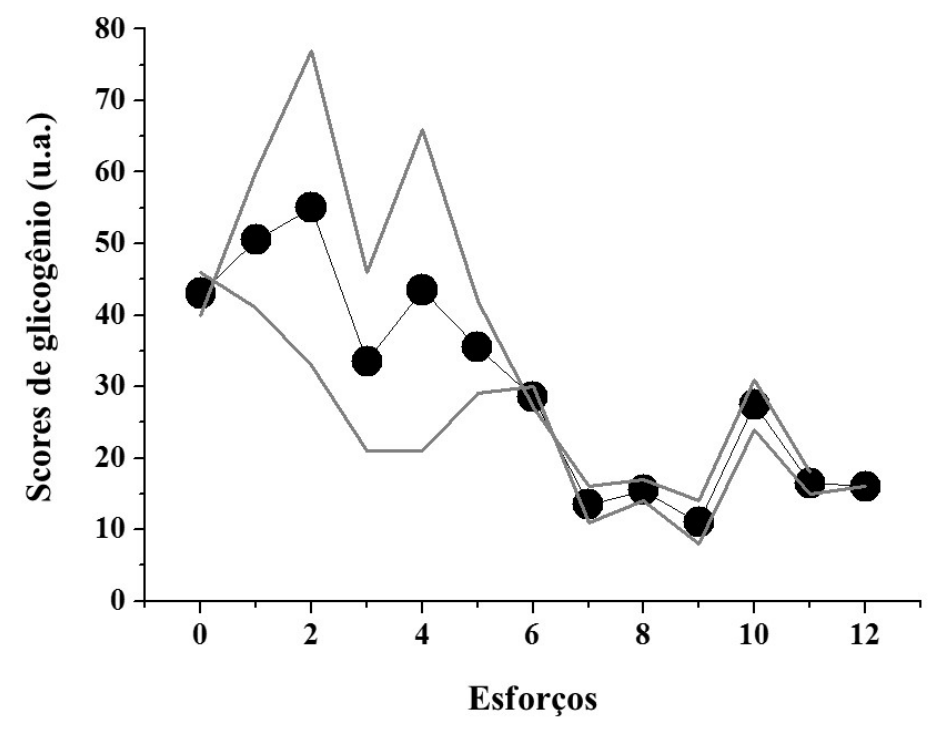

Figura 64. Comportamento dos scores de glicogênio muscular ao longo do esforço de depleção, obtidos por meio de imagens de ultrassom. Os símbolos representam os valores médios e as linhas os comportamentos individuais. 
Assim como observado na primeira tentativa de padronização do esforço de depleção, a força pico diminuiu ao longo do esforço $(\approx 9,4$ e $11,6 \mathrm{Kg})$, o que também ocorreu para os valores de TP $(\approx 1,4$ e 3,2 Kg). A diferença nos valores de TS foram menos expressivos do que os observados na primeira tentativa, apresentando respostas diferentes entre os dois participantes. A AV apresentou uma variação de 17,2\% e 13,4\% para os dois participantes. O comportamento destes parâmetros longo do esforço de depleção está apresentado na Figura 65. Diferentemente do primeiro esforço, onde parece ter ocorrido um quadro de fadiga periférica bem definido, nesta tentativa a diminuição dos valores de AV também indica uma diminuição da atividade do sistema nervoso central [4].
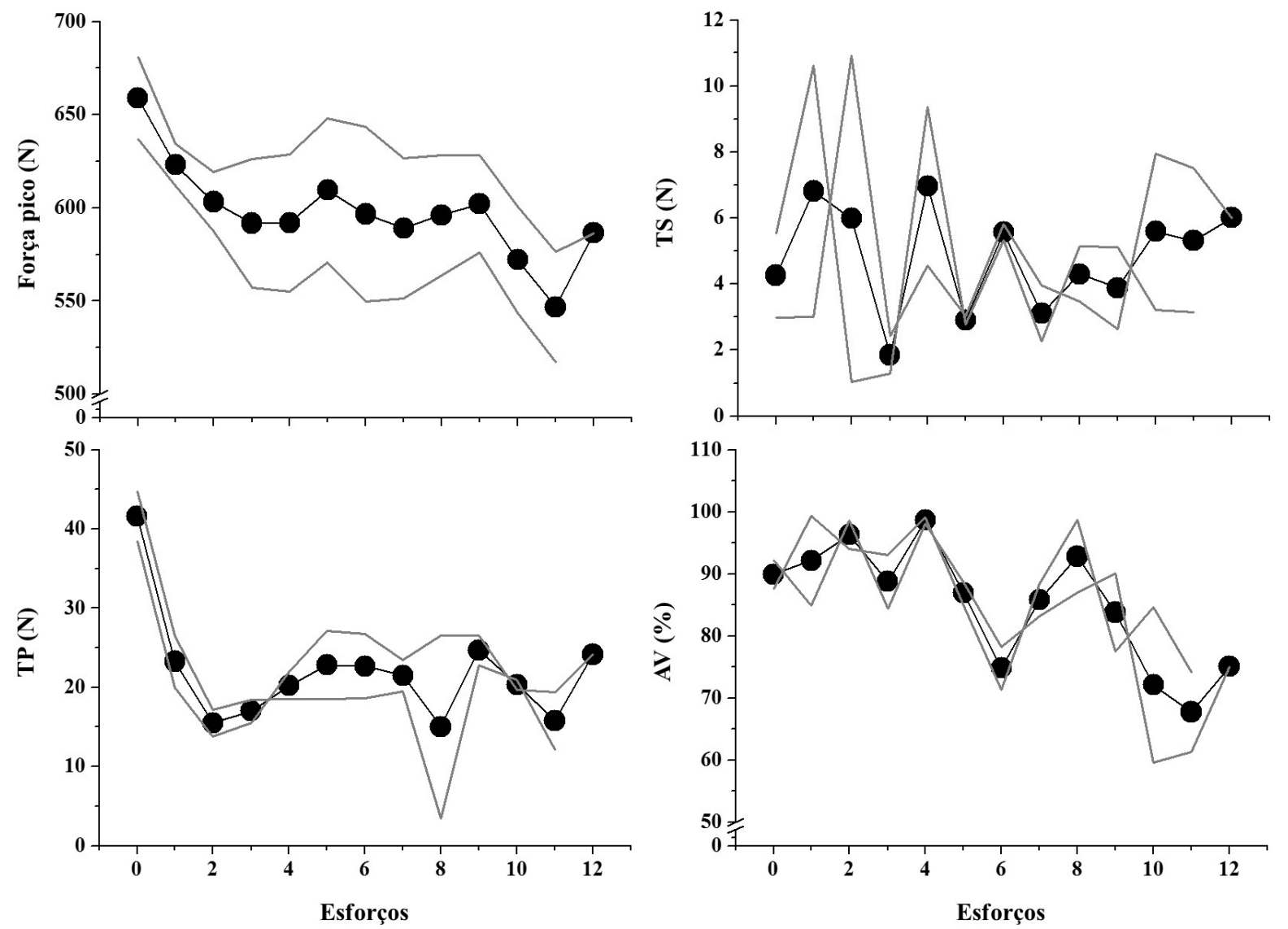

Figura 65. Comportamento dos parâmetros obtidos por meio da técnica de Twitch Interpolation observados ao longo do esforço de depleção. Os símbolos representam os valores médios e as linhas o comportamento individual. TS: força evocada com o estímulo elétrico 
durante a contração isométrica máxima; TP: força evocada com o estímulo elétrico aplicado no músculo relaxado; AV: ativação voluntária obtida por meio desta técnica.

O primeiro participante a realizar os esforços no domínio severo, suportou cinco esforços de um minuto a $120 \%$ da iVO $2 \mathrm{PICO}$, possibilitando uma boa avaliação do desenvolvimento da fadiga neste domínio. Entretanto, o segundo participante realizou apenas dois esforços, o que impossibilita as principais investigações do projeto principal. A força média observada nas botas do ergômetro e a potência desenvolvida durante os esforços no domínio severo, estão apresentadas na Figura 66. É importante salientar que ambos os participantes relataram um estado de "cansaço" ainda oriundo do esforço de depleção realizado $12 \mathrm{~h}$ antes.

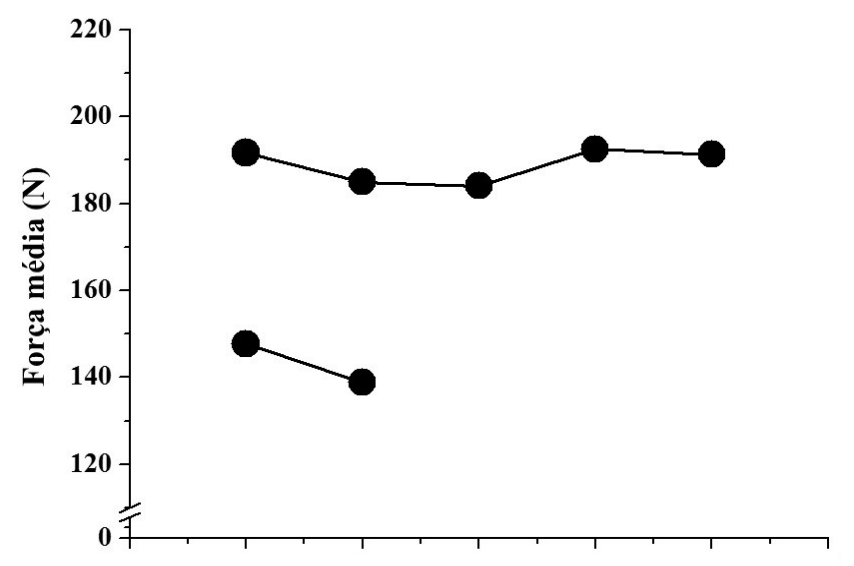

Figura 66. Comportamento individual da força média observada nas botas do ergômetro e a potência desenvolvida ao longo dos esforços realizados no domínio severo.

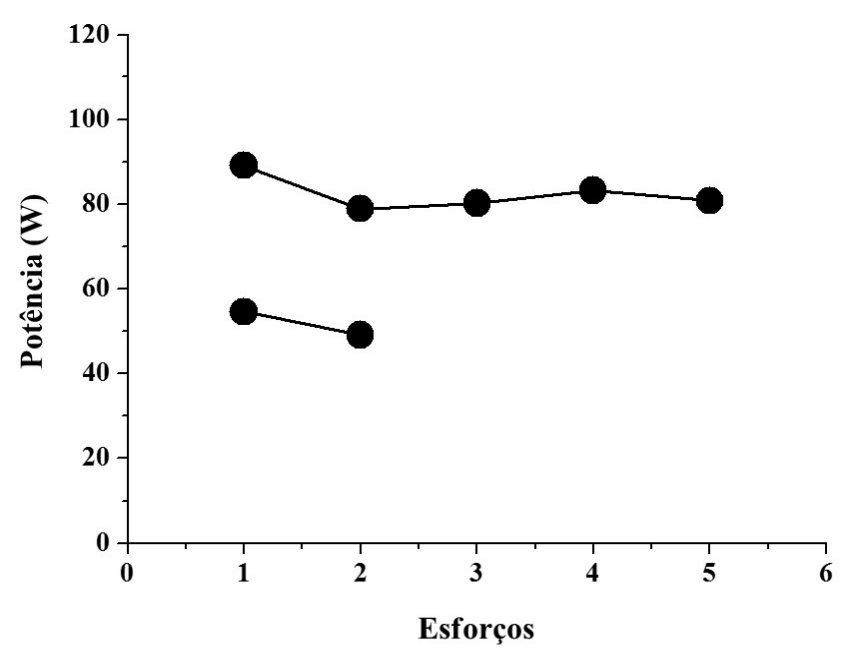

Os scores do conteúdo de glicogênio muscular aumentaram após 12 h de recuperação para 
os dois participantes $(+10$ e +12 u.a), mas continuaram abaixo dos valores observados antes da depleção (- 10 e - 11 u.a.) (Figura 67). Estes scores de glicogênio apresentaram um declínio para ambos os participantes até o segundo esforço no domínio severo. Entretanto, voltaram a aumentar nos últimos três esforços do participante que apresentou o melhor desempenho, comportamento não esperado para esta fase do exercício.

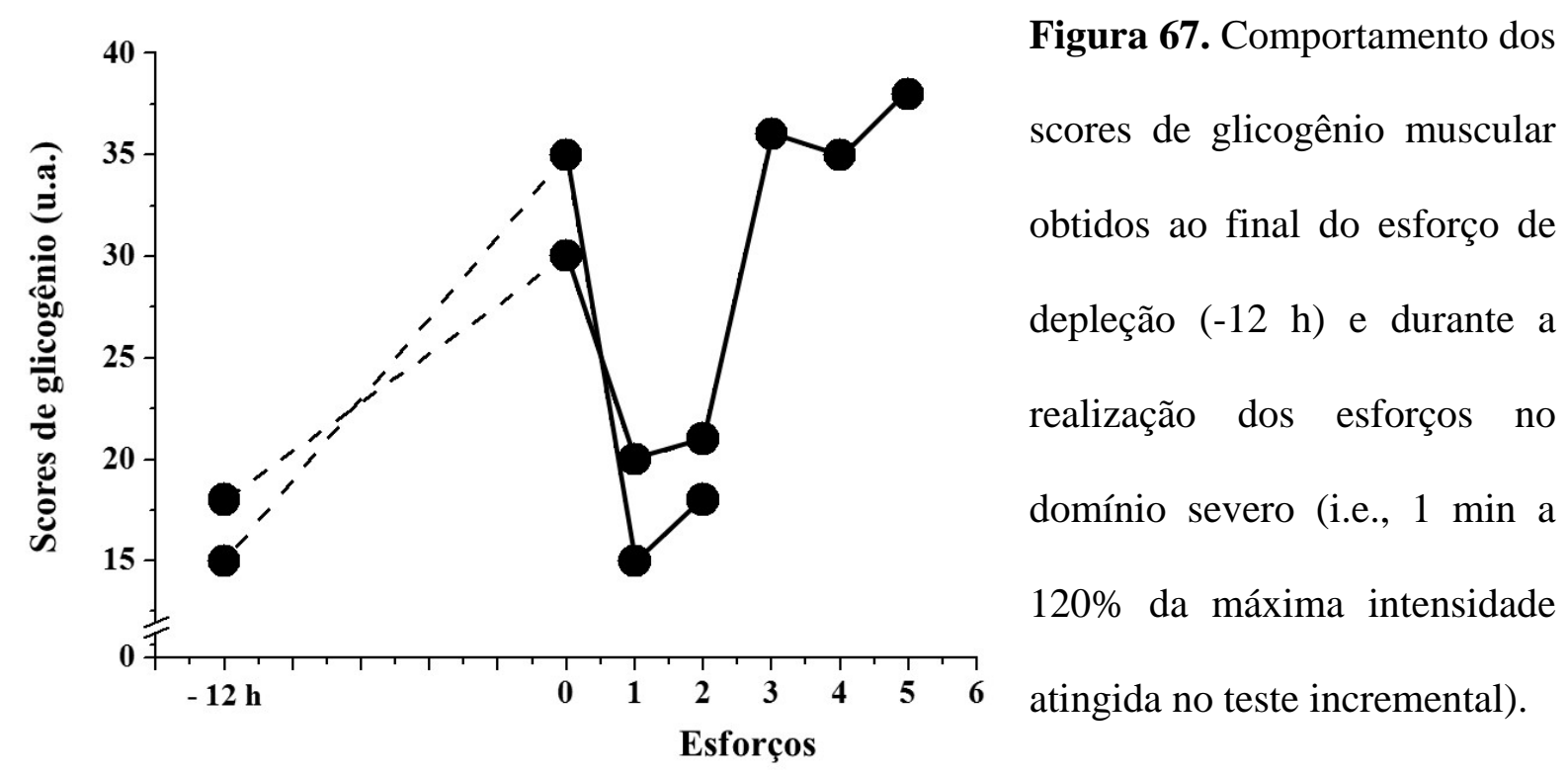

Os parâmetros provenientes da técnica de TI, estão apresentados na Figura 68. A força pico aumentou após as 12 h de recuperação, mas ao longo dos esforços no domínio severo uma queda entre as mensurações de repouso e a última contração isométrica máxima foi observada, para os dois participantes $(-46,7 \mathrm{Ne}-34,1 \mathrm{~N})$. Os valores de TS e TP também apresentaram uma recuperação após 12 h. Além disso, estes parâmetros provenientes da técnica de TI, diminuíram ao longo dos esforços no domínio severo, o que também ocorreu para ambos os participantes (TS: $-2,5 \mathrm{Ne}-1,01 \mathrm{~N}$; TP: $-29,8 \mathrm{Ne}-21,2 \mathrm{~N}$ ). Entretanto, a AV não apresentou grandes alterações ao longo dos esforços. Considerando as diminuições concomitantes na força pico, TS e TP, sem alterações na AV, podemos inferir que a fadiga apresentada por estes dois 
participantes foi de caráter periférico em esforços no domínio severo [33].
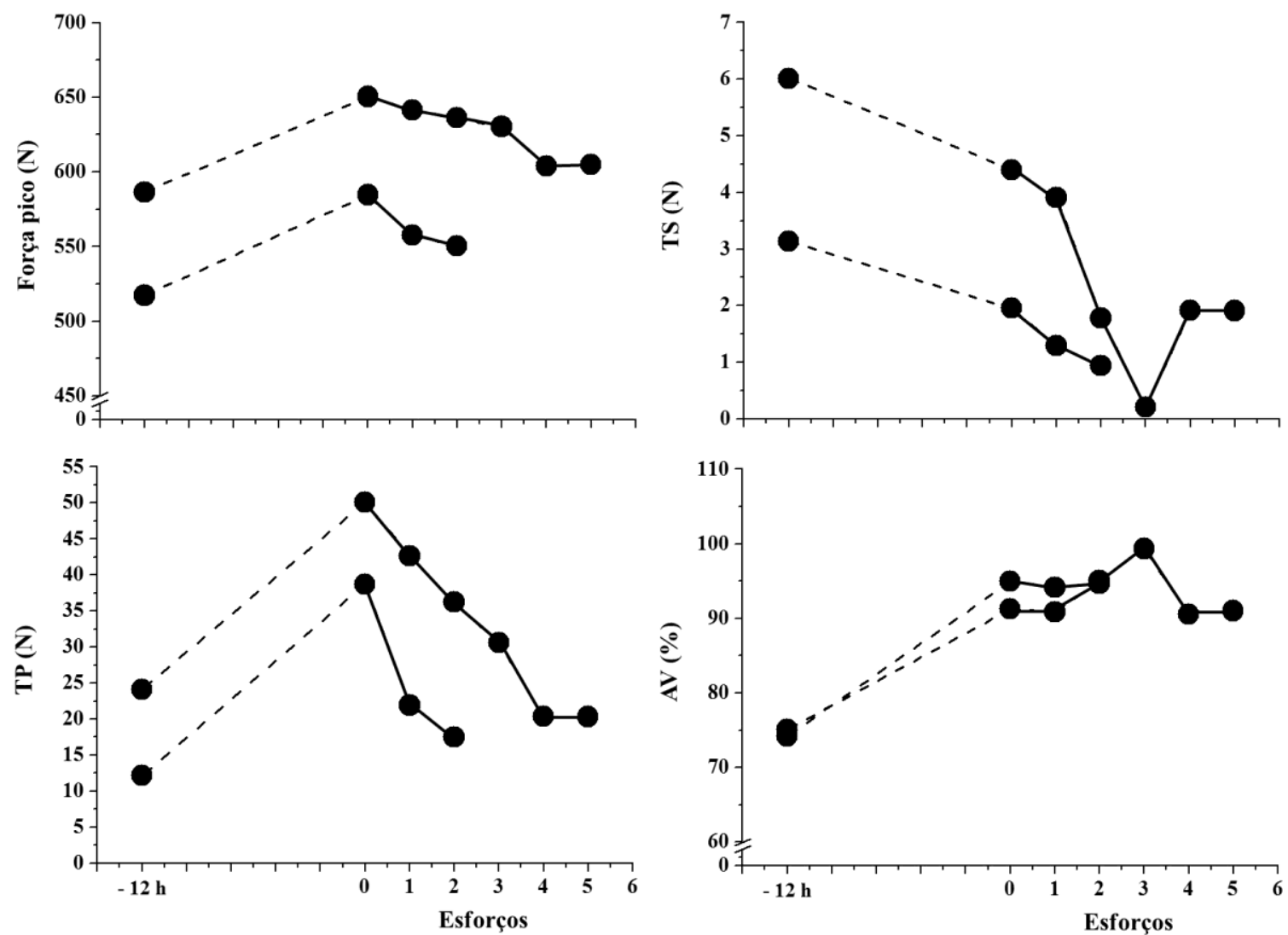

Figura 68. Comportamento dos parâmetros obtidos por meio da técnica de Twitch Interpolation observados após o esforço de depleção $(-12$ h) e ao longo dos esforços no domínio severo. TS: força evocada com o estímulo elétrico durante a contração isométrica máxima; TP: força evocada com o estímulo elétrico aplicado no músculo relaxado; AV: ativação voluntária obtida por meio desta técnica.

\section{Considerações do capítulo}

Consideramos os experimentos apresentados neste capítulo como sendo de grande importância para o projeto principal, principalmente por terem ajudado a caracterizar o esforço de depleção e o feedback dos participantes em relação às $12 \mathrm{~h}$ de recuperação. Estes resultados 
nortearam as decisões e os delineamentos dos experimentos principais do projeto de pesquisa, os quais estão apresentados nos próximos capítulos. Um resumo dos principais resultados está apresentado abaixo:

- Embora o LabView ${ }^{\circledR}$ possibilite a observação dos dados de força em tempo real, o armazenamento destas aquisições aumenta demasiadamente o intervalo entre os esforços da depleção. Desse modo, optamos por utilizar em todas as próximas etapas o sistema de aquisição operado por rotinas específicas construídas em ambiente Matlab ®;

- A intensidade de $70 \%$ da iVO2PICO pode ser utilizada durante os esforços de depleção, embora pequenos ajustes devam ser realizados durante o exercício, para garantir o cumprimento do volume (tempo de esforço) dos estímulos. Com isso, para diminuir o possível viés causado por este procedimento, apenas um avaliador foi responsável por realizar estes ajustes em todos os experimentos descritos nos próximos capítulos.

- Após um volume considerável de exercício a $70 \%$ da $\mathrm{iVO}_{2 \mathrm{PICO}}$, as fibras do tipo II necessitam que seus estoques de glicogênio sejam diminuídos. Entretanto, respostas muito divergentes foram observadas entre os participantes. Com isso, durante os experimentos principais do presente projeto, utilizaremos apenas um esforço de alta intensidade ao final do exercício de depleção. Na tentativa de diminuir a variabilidade observada neste procedimento, este esforço será realizado até a exaustão, na intensidade correspondente a iVO2PICO. Assim, esperamos aumentar o tempo de permanência em alta intensidade (i.e., > 2 min), cumprindo de uma maneira mais robusta o propósito de depleção das fibras tipo II.

- Embora todas as variáveis estudadas tenham apresentado uma recuperação ao menos parcial, acreditamos que $12 \mathrm{~h}$ de recuperação entre o esforço de depleção e o esforço de interesse tenha sido um tempo insatisfatório, comprometendo o desempenho nos esforços do domínio 
severo. Assim, nos experimentos apresentados nos próximos capítulos respeitamos intervalos de pelo menos 24 h entre o esforço de depleção e o exercício realizado no domínio de interesse.

- A variabilidade apresentada em esforços realizados até o Tlim tem sido considerável, desde os primeiros experimentos no ergômetro de extensão dinâmica de joelhos. Este fato poderia comprometer as conclusões sobre os resultados deste projeto, principalmente por i) possibilitar um número insatisfatório de esforços, como ocorreu no domínio severo durante a segunda tentativa de padronização e ii) como cada participante deveria apresentar um nível de desempenho diferente (i.e., diferentes números de esforços), as comparações estatísticas não poderiam ser realizadas em "isotime". Considerando estas limitações, optamos por alterar os esforços de interesse nos diferentes domínios de intensidade. O projeto inicial previa a realização de esforços com cargas constantes até a exaustão, onde o Tlim seria o principal índice de desempenho avaliado. Após estes experimentos preliminares, fixamos um volume a ser cumprido em cada esforço de interesse, com intensidades iniciais correspondentes ao domínio a ser estudado. Durante todos estes esforços, pequenos ajustes na intensidade podem ocorrer, assim como padronizamos durante o esforço de depleção, priorizando assim o cumprimento do volume proposto. 


\section{V - A PADRONIZAÇÃO DAS BIÓPSIAS E DETERMINAÇÃO DO GLICOGÊNIO MUSCULAR (voltar ao documento principal)}

Embora a utilização do ultrassom tenha possibilitado a determinação de vários pontos de glicogênio ao longo do exercício e de sua recuperação, o equipamento que utilizamos ficou indisponível. Várias tentativas foram realizadas, considerando possíveis parcerias com laboratórios da Universidade de São Paulo - Ribeirão Preto e do Instituto Federal de Minas Gerais - Muzambinho, mas não tivemos acesso a nenhum equipamento compatível com a plataforma da MuscleSound ${ }^{\circledR}$, impossibilitando a determinação dos scores de glicogênio. Diante desta importante limitação metodológica, decidimos alterar radicalmente o delineamento experimental, sem perder o foco na pergunta central do presente projeto e ainda utilizar uma metodologia considerada "padrão ouro" para estimativa do glicogênio muscular.

Consideramos as sugestões do professor Prof. Dr. Nikolai Baastrup Nordsborg, que durante a sua visita técnica ao nosso laboratório em novembro de 2016, questionou a não utilização da biópsia muscular no presente projeto. De fato, a utilização da biópsia muscular para a confirmação das concentrações de glicogênio aumentaria o nível de fidedignidade das mensurações pretendidas, além de possibilitar outras análises não vislumbradas no projeto inicial. Entretanto, na época, explicamos que os procedimentos de biópsia muscular não faziam parte da rotina do nosso laboratório e que, considerando os estudos de validação, as imagens de ultrassom seriam suficientes para responder nossa pergunta central.

Além deste professor dinamarquês, os docentes Prof. Dr. Claudio Alexandre Gobatto e Prof ${ }^{a}$. Dr. Fúlvia de Barros Manchado Gobatto também realizaram uma visita técnica ao nosso laboratório. Nesta ocasião, após apresentação do presente projeto e uma extensa discussão, os professores sugeriram um período maior para a depleção do glicogênio muscular. Neste caso, os esforços de depleção seriam aplicados durante vários dias, sendo acompanhados por uma 
dieta com baixas quantidades de carboidrato. Os exercícios de interesse seriam realizados ao final deste período (i.e., situação B-Glic) e após alguns dias de uma dieta com altas quantidades de carboidratos (i.e., situação R-Glic). Desse modo, teoricamente, teríamos uma situação com baixas quantidades de glicogênio e outra aproveitando o fenômeno da supercompensação deste substrato [74].

Considerando as importantes sugestões destes pesquisadores juntamente com a possibilidade real de realização de biópsia muscular, o delineamento do presente projeto foi alterado. Nessa nova abordagem metodológica, optamos por promover duas situações bastante distintas de avaliação, uma com baixo e outra com elevados níveis de glicogênio muscular, o que foi induzido por meio do procedimento de supercompensação deste substrato muscular [74]. Consideramos estas alterações uma "evolução científica" adotada pela presente tese, utilizando metodologias mais robustas para responder a nossa pergunta central.

\section{Procedimentos de biópsia muscular}

As amostras foram extraídas das duas pernas, de maneira randomizada e contrabalanceada entre as duas visitas. Todos os procedimentos foram realizados por uma médica com treinamento específico em extração de tecido muscular, nas dependências do Laboratório de Fisiologia e Desempenho Esportivo, coordenado pelo Prof. Dr. Alessandro Moura Zagatto da UNESP, campus de Bauru. A região de interesse (porção medial do músculo vasto lateral) foi tricotomizada e limpa com liquido antisséptico. $\mathrm{Na}$ sequência, a região foi anestesiada com xilocaína (2\%), permitindo a realização de uma incisão de aproximadamente $5 \mathrm{~mm}$ até a fáscia do músculo. O tecido muscular foi extraído por meio de uma agulha específica para biópsia muscular, a qual foi inserida a uma profundidade de aproximadamente 2,5 a $3 \mathrm{~cm}$. Em média foram extraídos $0,111 \pm 0,04 \mathrm{~g}$ e 0,101 $\pm 0,02 \mathrm{~g}$ na primeira e na segunda visitas, 
respectivamente. As amostras de tecido foram imediatamente congeladas por meio de nitrogênio líquido e posteriormente armazenados $-80^{\circ} \mathrm{C}$. Os procedimentos estão ilustrados na Figura 69.

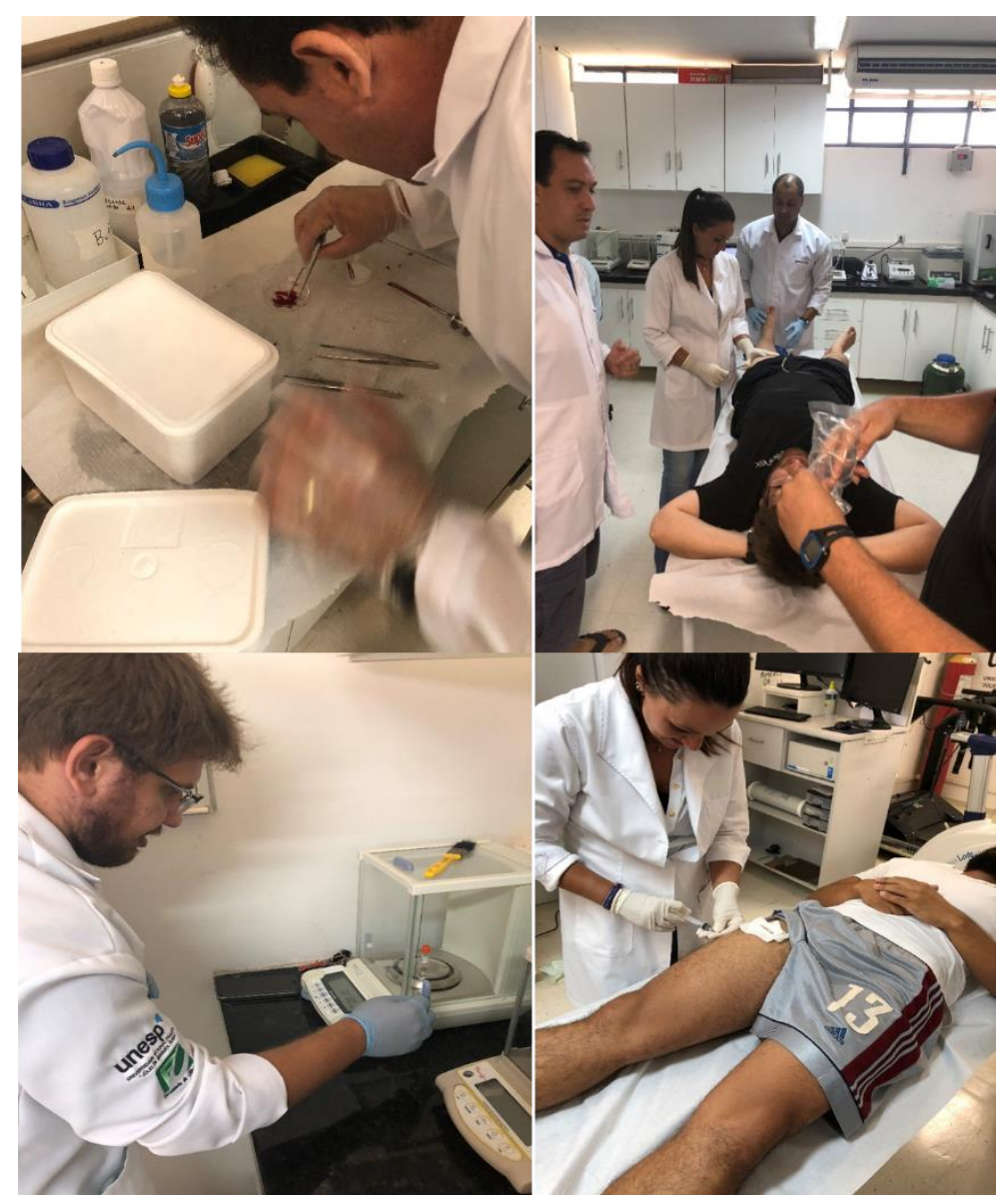

Figura 69. Registro dos procedimentos de biópsia muscular realizados em parceria com o Laboratório de Fisiologia e Desempenho Esportivo.

Todos os procedimentos relacionados a determinação do glicogênio muscular foram realizados no Laboratório de Fisiologia Aplicada ao Esporte (LAFAE), coordenado pelo Prof. Dr. Gobatto e Prof ${ }^{a}$. Dra . Manchado-Gobatto, e sobre supervisão do doutorando Pedro Paulo Menezes Scariot, os quais somos muito gratos pela paciência e disponibilidade.

As concentrações de glicogênio foram determinadas por método colorimétrico, conforme proposto por Dubois et al. [135]. Para isso, os tecidos foram digeridos em banho a 
$100{ }^{\circ} \mathrm{C}$ utilizando $0,5 \mathrm{~mL}$ de $\mathrm{KOH} 1 \mathrm{~N}$ durante 20 minutos. Posteriormente foram adicionados $20 \mu \mathrm{L}$ de solução saturada de $\mathrm{Na} 2 \mathrm{SO} 4$, sendo o glicogênio precipitado por meio de duas passagens de 2,5 mL de etanol a quente, seguida de centrifugação em $4 \mathrm{~mL}$ de água. A determinação colorimétrica foi realizada em $1 \mathrm{mM}$ de extrato, $20 \mu \mathrm{L}$ de fenol a $80 \%$ e $2,0 \mathrm{~mL}$ de ácido sulfúrico concentrado, após fervura de 15 minutos. A absorbância foi medida em espectrofotômetro 490nm. Sete padrões foram confeccionados por meio de soluções conhecidas de glicose entre 10 e 90 g.mL $\mathrm{mL}^{-1}$. A curva de calibração foi construída por meio da relação linear da absorbância evidenciada nos sete diferentes padrões de concentrações, apresentando elevados índices de linearidade $\left(r^{2}=0,998\right)$.

Embora esta técnica seja muito utilizada, suas padronizações foram realizadas para quantidades maiores de tecido (i.e., $200 \mathrm{mg}$ ). Desse modo, realizamos ensaios preliminares para que as concentrações de glicogênio nas diferentes situações (i.e., B-Glic e R-Glic), ficassem dentro da curva de absorbância esperada, mesmo quando utilizássemos amostras de tecido menores. Para as concentrações observadas na situação B-Glic, o protocolo padrão foi mantido, principalmente porque a coloração das amostras após adicionarmos o ácido sulfúrico ficou dentro da curva padrão. Assim para a situação de B-Glic, utilizamos para a análise de absorbância $300 \mu \mathrm{L}$ de amostra. Entretanto, na situação em que os estoques de glicogênio foram supercompensados, considerando a elevada concentração de glicogênio nesta situação, apenas $20 \mu \mathrm{L}$ de amostra foram necessários, o que foi identificado após quatro ensaios. Estas diferenças foram corrigidas posteriormente, conforme proposto pela equação da metodologia original [135]. A coloração dos diferentes ensaios em relação aos padrões, podem ser observados na Figura 70. A coloração das diferentes amostras obtidas no presente projeto, podem ser observadas na Figura 71. 


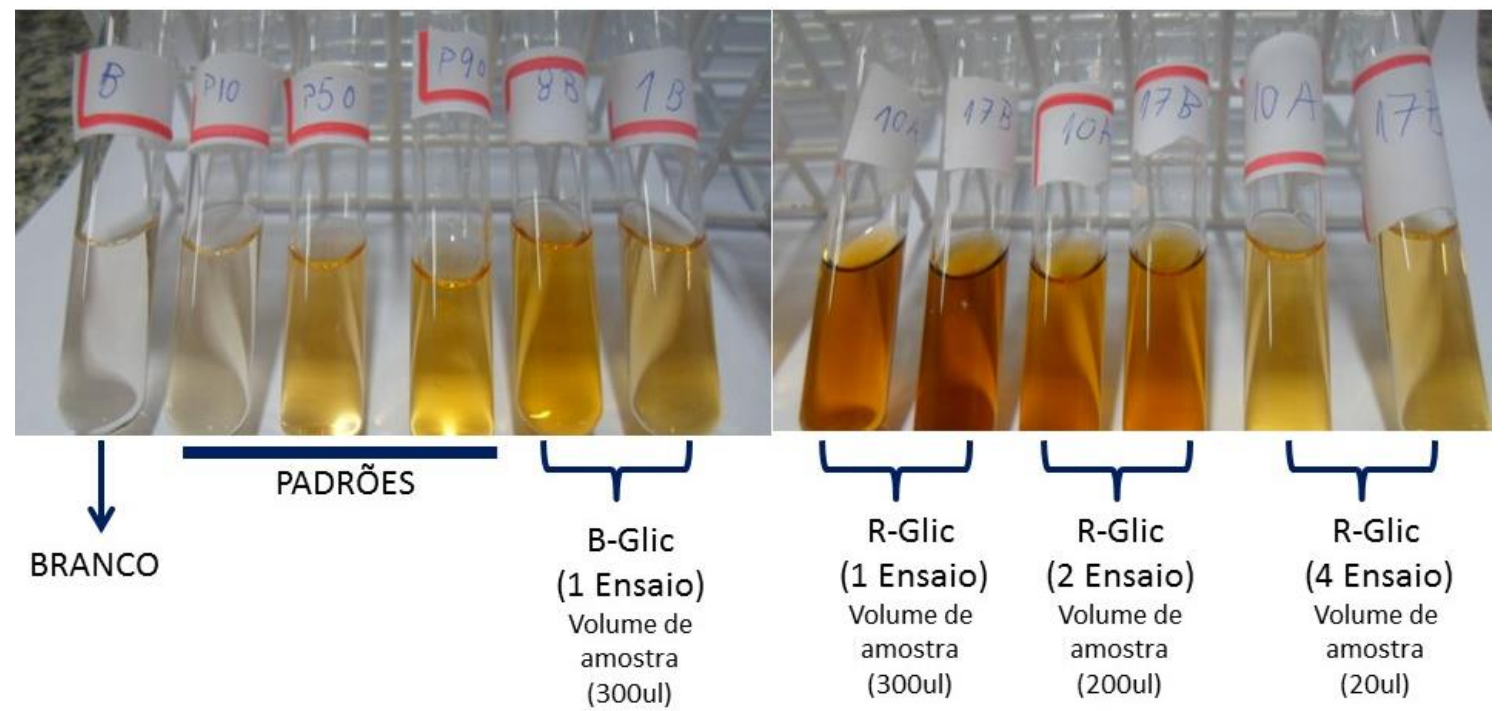

Figura 70. Coloração das amostras em relação aos padrões nas situações após a depleção (i.e., baixas concentrações; B-Glic) e após o período de supercompensação (i.e., concentrações recuperadas; R-Glic).

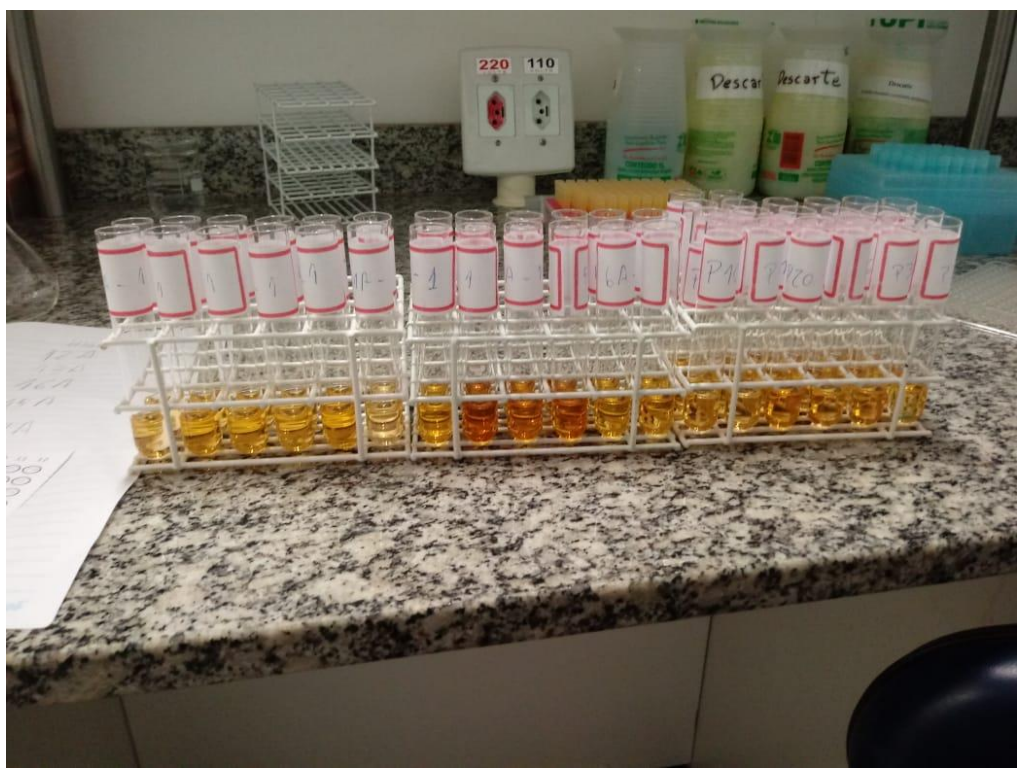

Figura 71. Coloração das amostras finais utilizadas para a determinação das concentrações de glicogênio muscular do presente projeto de pesquisa. 


\section{VI - A TÉCNICA DE ESTIMULAÇÃO MAGNÉTICA TRANSCRANIANA (voltar ao documento principal)}

Todos os procedimentos relacionados a técnica de EMT, foram realizados utilizando os equipamentos do Laboratório de Biomagnetismo da Faculdade de Filosofia, Ciências e Letras da USP de Ribeirão Preto, coordenado pelo Prof. Dr. Oswaldo Baffa Filho e ajuda incondicional dos doutorandos Renan Hiroshi Matsuda e Victor Hugo de Oliveira e Souza. Os estímulos da EMT foram orientados por um software de neuronavegação idealizado e validado pelo referido laboratório (Figura 72 e 73; ou https://www.youtube.com/watch?v=KWooQhgCafQ\&t=74s).

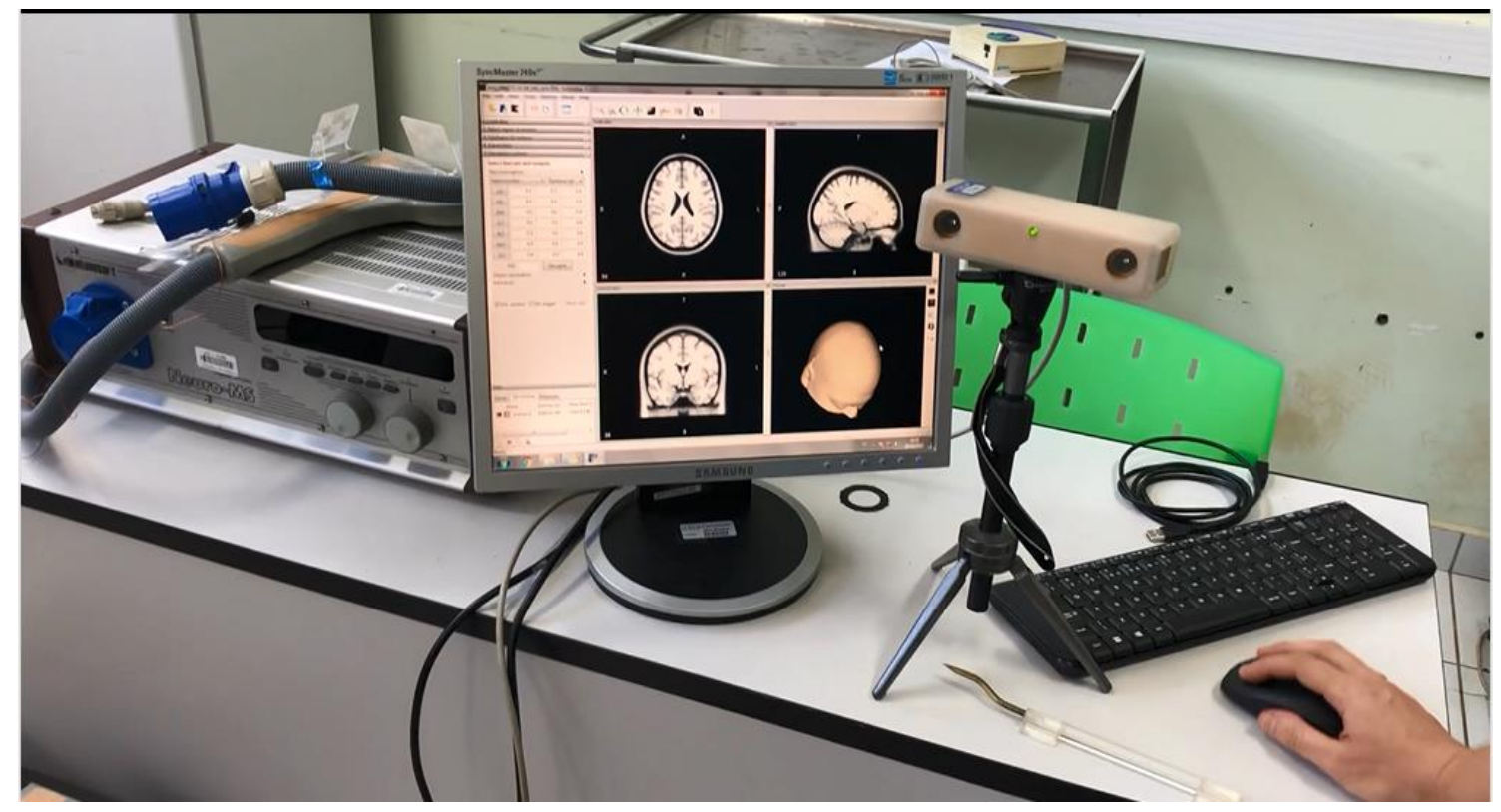

Figura 72. Layout do neuronavegador e a câmera utilizada para o rastreamento da bobina em relação a cabeça do avaliado. 


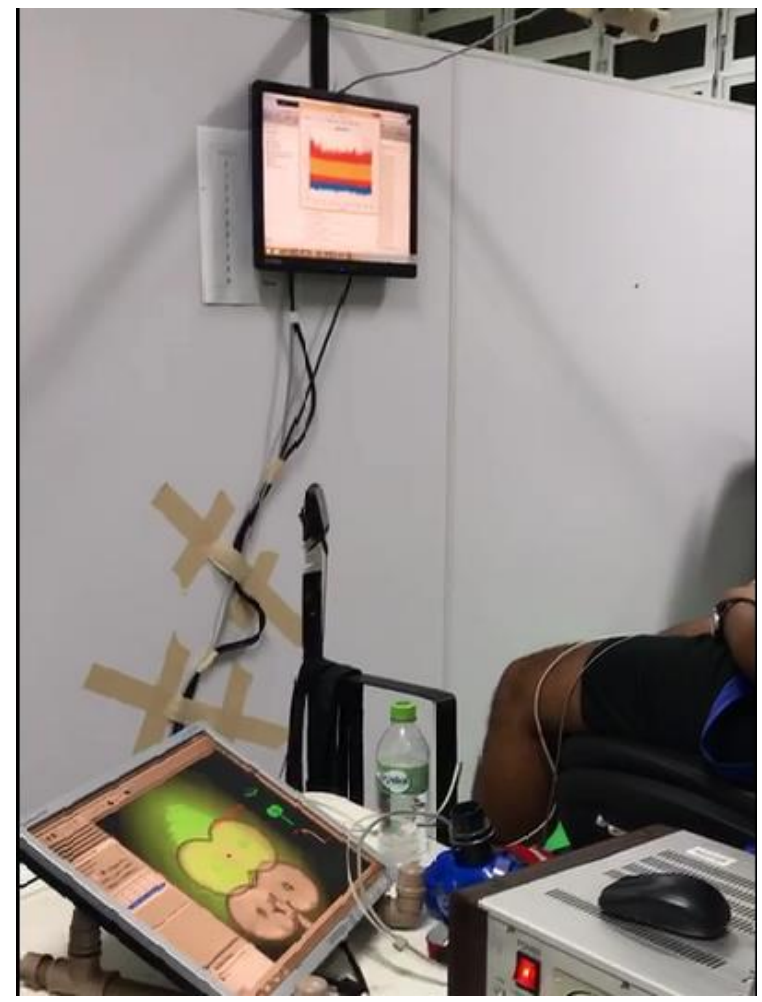

Figura 73. Disposição do neuronavegador para aplicação dos estímulos magnéticos da técnica de estimulação magnética transcraniana e a força em tempo real, possibilitando o participante manter o esforço a $20 \%$ de uma contração isométrica máxima.

O comportamento típico da força durante o procedimento de EMT está demonstrado na Figura 74. Em todos os casos foram aplicados pelo menos 10 estímulos magnéticos durante uma contração isométrica submáxima. Este procedimento foi adotado para que a média das cinco melhores estimulações fosse utilizada nas análises. A Figura 75 demonstra o comportamento típico do sinal de EMG durante o procedimento de EMT, o que permitiu a determinação da amplitude do estímulo (Amp), do tempo entre os picos positivo e negativo (Tp-p) e do tempo de silencio (i.e., tempo após o estímulo para que o sinal de EMG volte a ter o comportamento característico de uma contração isométrica; Tsil). Como é característico deste procedimento, os estímulos apresentam uma perceptível variação ao longo da contração isométrica (Figura 76), o que é suavizado pela utilização da média das estimulações de interesse. No caso do presente estudo, as cinco estimulações que evocaram os maiores valores de força (Figura 77). 

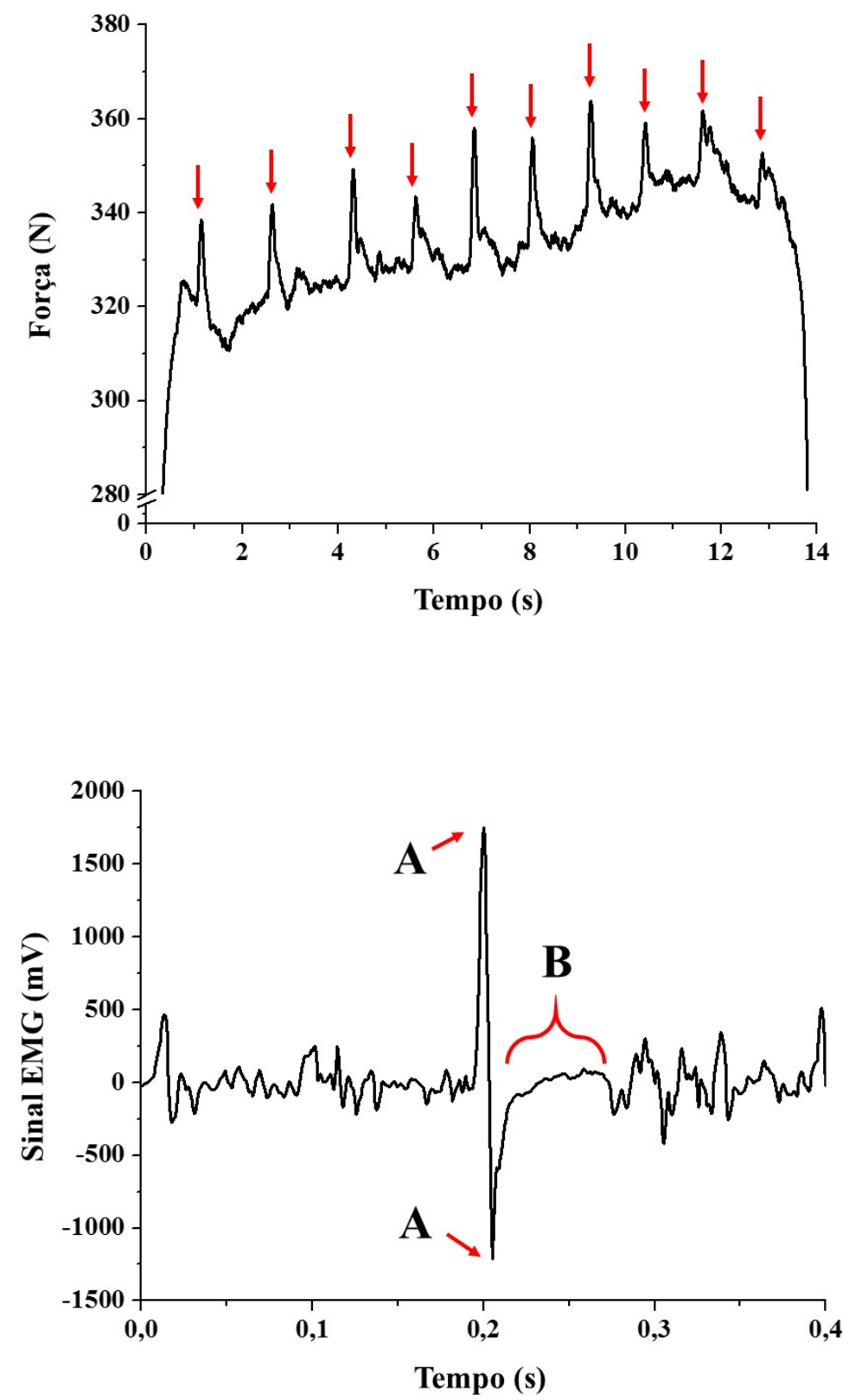

Figura 74. Comportamento da força observada durante os procedimentos da técnica de estimulação magnética transcraiana (EMT). $\downarrow:$ Momentos de estímulo magnético.
Figura 75. Comportamento do sinal de EMG observado durante os procedimentos da técnica de estimulação magnética transcraiana (EMT). A: picos positivos e negativos induzidos pelo estímulo magnético; $\mathrm{B}$ : tempo até que o sinal de EMG

volte a ter um aspecto típico de uma contração submáxima (i.e., tempo de silencio). 


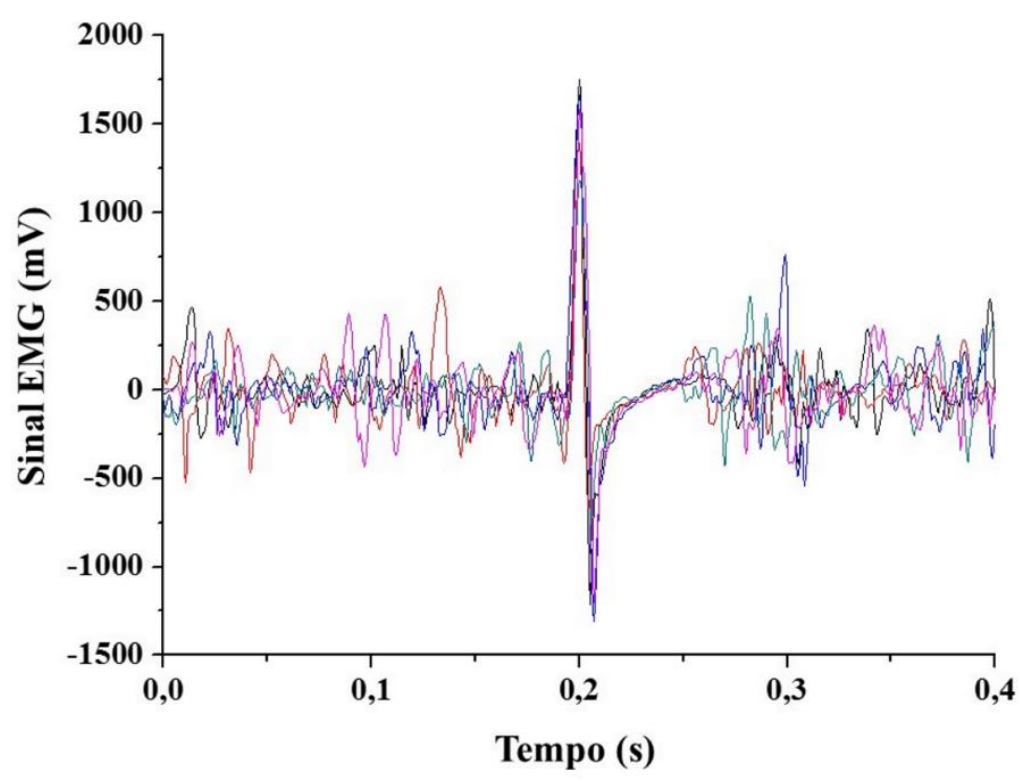

Figura 76. Comportamento do sinal de EMG observado durante os procedimentos da técnica de estimulação magnética transcraiana (EMT). Esta figura representa a variação dos cinco melhores estímulos realizados durante uma contração submáxima.

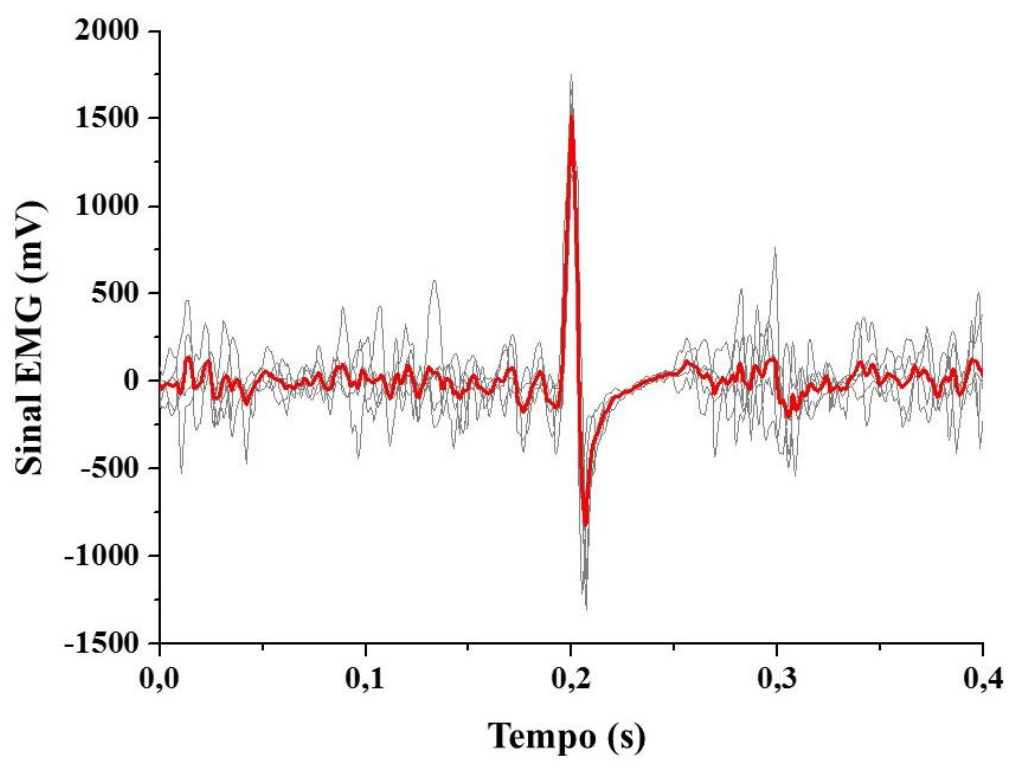

Figura 77. Para suavizar o sinal de EMG durante a técnica de estimulação magnética transcraniana, utilizamos a média das cinco melhores estimulações, a qual está destacada em vermelho.

Entretanto, embora todos os cuidados tenham sido tomados, tais como a utilização de neuronavegador e a determinação da melhor intensidade de estímulo, observamos sinais de EMG atípicos para esta técnica de EMT (Figura 78). De fato, consideramos que apenas 49\% (n = 59 das 128 possíveis EMT previstas) apresentaram sinais confiáveis. A Figura 79 demonstra a efetividade da EMG nos momentos de avaliação ao longo do delineamento experimental. 
Considerando que todas as tentativas foram inconsistentes após o segundo esforço no domínio pesado na situação R-Glic, as comparações entre as situações foram realizadas apenas entre os esforços no domínio moderado $(\mathrm{n}=5)$.

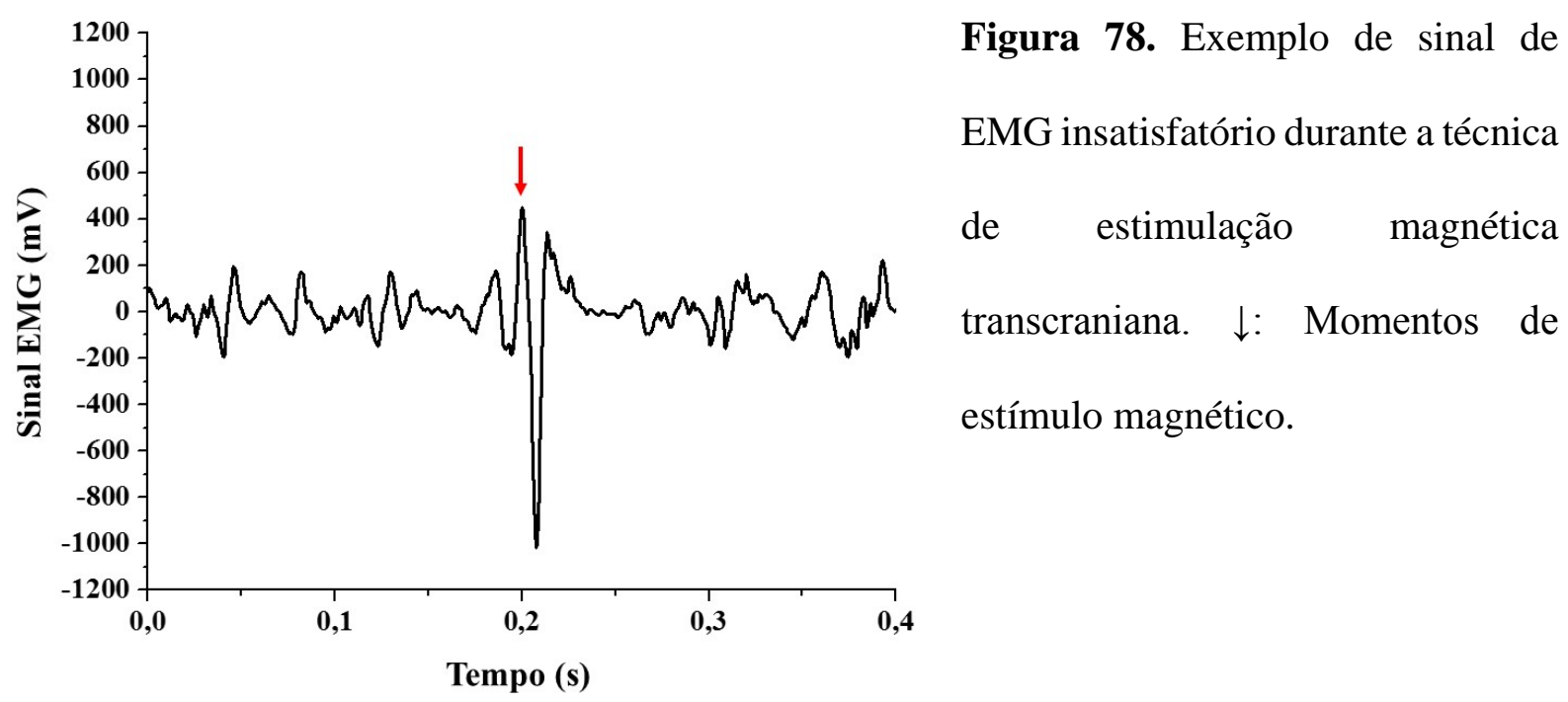

\begin{tabular}{|c|c|c|c|c|c|}
\hline E0 & E1 & $\mathbf{E 2}$ & $\mathbf{E 3}$ & Efetividade & $\mathbf{n}$ \\
\hline \multirow[t]{2}{*}{32} & 32 & 32 & 32 & $100 \%$ & 8 \\
\hline & & & Pesado B-Glic & & \\
\hline \multirow[t]{2}{*}{5} & 5 & 4 & 4 & $56,25 \%$ & 4 \\
\hline & & & Moderado B-Glic & & \\
\hline \multirow[t]{2}{*}{5} & 5 & 5 & 5 & $62,5 \%$ & 5 \\
\hline & & & Pesado R-Glic & & \\
\hline \multirow[t]{2}{*}{2} & 1 & $\mathbf{0}$ & 2 & $15,6 \%$ & $\mathbf{0}$ \\
\hline & & & Moderado R-Glic & & \\
\hline 5 & 5 & 5 & 5 & $62,5 \%$ & 5 \\
\hline
\end{tabular}

Figura 79. Efetividade da técnica de estimulação magnética transcraniana ao longo do delineamento experimental proposto. B-Glic: situação com baixas quantidades de glicogênio muscular; R-Glic: situação onde o glicogênio muscular foi recuperado. 


\section{VII - A DETERMINAÇÃo do TRIPTOFANO SANGUínEO TOTAL}

\section{(voltar ao documento principal)}

As análises de TrP foram realizadas no Laboratório de Eletrocatálise e Eletroquímica Ambiental (LEEA) da Faculdade de Filosofia, Ciências e Letras da USP de Ribeirão Preto, por intermédio do professor Dr. Paulo Olivi e supervisão da técnica Mercia Virginia Carlos.

As amostras de TrP foram obtidas por meio de cromatografia líquida de alta eficiência de fase reversa (do inglês High performance liquid chromatography, HPLC) (Shimadzu SPDM10AVP, Japan). Embora os procedimentos para a determinação do TrP por esta técnica tenham sido detalhadamente descritos por Sultana et al. [73], fatores como o modelo do equipamento e da coluna, a marca e pureza dos reagentes e padrões utilizados, podem influenciar no cromatograma observado. Com isso, embora tenhamos uma boa base teórica para iniciar as análises, várias padronizações são necessárias para que os resultados de TrP tenham a precisão pretendida.

Para todas as tentativas, utilizamos uma coluna C-18 (4,6x250mm), um fluxo de entrada de 1,5 mL.min ${ }^{-1}$, volume amostral de $20 \mu \mathrm{L}$ e fase móvel composta por Acetonitrila nível HPLC (Sigma-Aldrich, USA) e água ultrapura com pH de 2,7; ajustado pela adição de ácido ortofosfórico nível HPLC. Os picos de TrP foram analisados a $273 \mathrm{~nm}$ [73]. Os demais parâmetros relacionados à rotina de amostragem foram descritos conforme as tentativas descritas abaixo. Em todos os casos soluções padrão foram elaboradas a partir de uma solução base com concentração de $100 \mu \mathrm{g} \cdot \mathrm{mL}^{-1}$ de TrP (Synth ${ }^{\circledR}$, Brasil).

A primeira tentativa foi a utilização da fase móvel sendo composta $10 \%$ de acetonitrila e $90 \%$ de água de $\mathrm{pH} 2,7$, o que induziu a uma pressão sistêmica de $83 \mathrm{Kgf} / \mathrm{cm}^{3}$. Para estas tentativas, uma solução padrão com concentração $20 \mu \mathrm{g} \cdot \mathrm{mL}^{-1}$ de $\operatorname{TrP}$ foi utilizada. Na primeira tentativa a solução padrão foi injetada e o tempo de corrida foi ajustado para 20 min (Figura 
80). Embora um pico de detecção tenha ocorrido logo aos 1,983 min, o cromatograma apresentou uma base larga e picos adjacentes, indicando sobreposição de compostos [136]. Este comportamento foi reprodutível para as amostras com concentração de 10,7 e $5 \mu \mathrm{g} . \mathrm{mL}^{-1}$ (Figura 81). Além destas amostras padrão, também testamos o comportamento de uma amostra de plasma $(20 \mu \mathrm{L})$, preparada utilizando Metanol nível HPLC $(200 \mu \mathrm{L})$ para a desproteinização e Fosfato de Sódio (100 $\mu \mathrm{L})$ para a suspensão. O cromatograma, mais uma vez, apresentou um aspecto inesperado, com um pico de base larga e vários picos adjacentes (Figura 82). Buscamos diferentes alternativas para corrigir estas imperfeições. Na primeira tentativa, alteramos a forma de preparo da amostra, diluindo $20 \mu \mathrm{L}$ de plasma em $40 \mu \mathrm{L}$ de HCL $0,5 \mathrm{M}$, aproximando sua condição com a fase móvel proposta (i.e., meio ácido). Embora a base do pico tenha estreitado, picos adjacentes ainda foram observados (Figura 82), impossibilitando sua utilização.

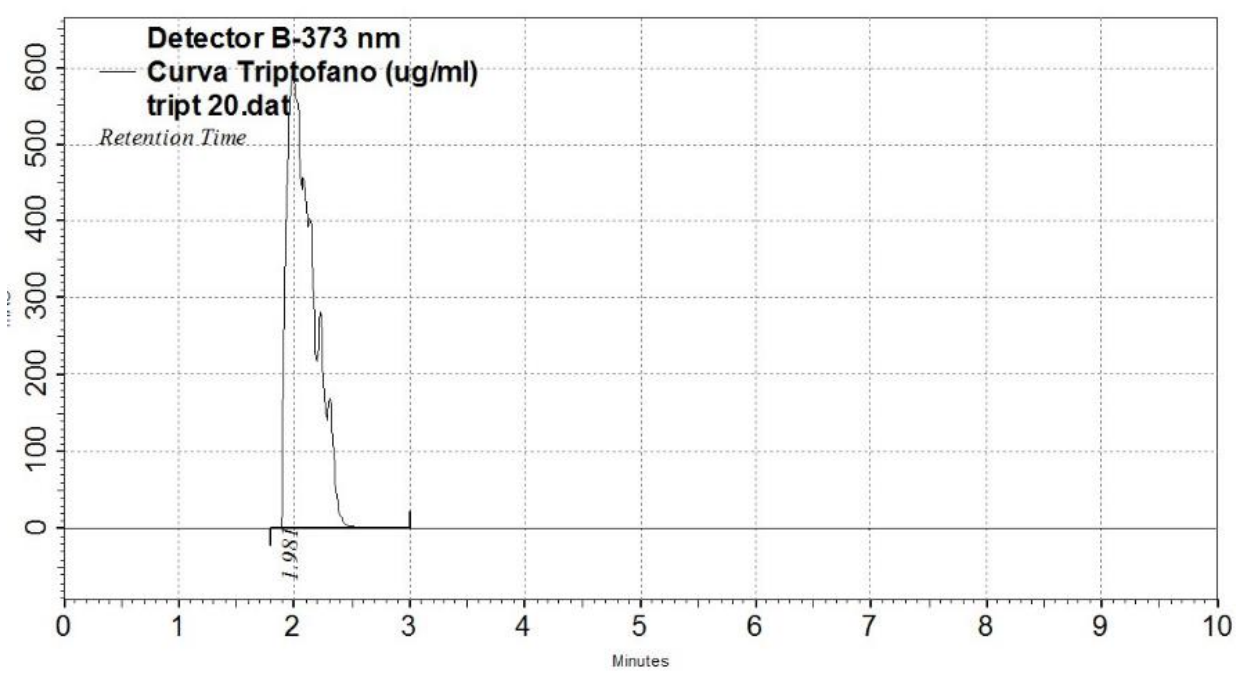

Figura 80. Cromatograma da primeira tentativa para dosagem das concentrações de triptofanao em solução contendo $20 \mu \mathrm{g} \cdot \mathrm{mL}^{-1}$ de padrão. 

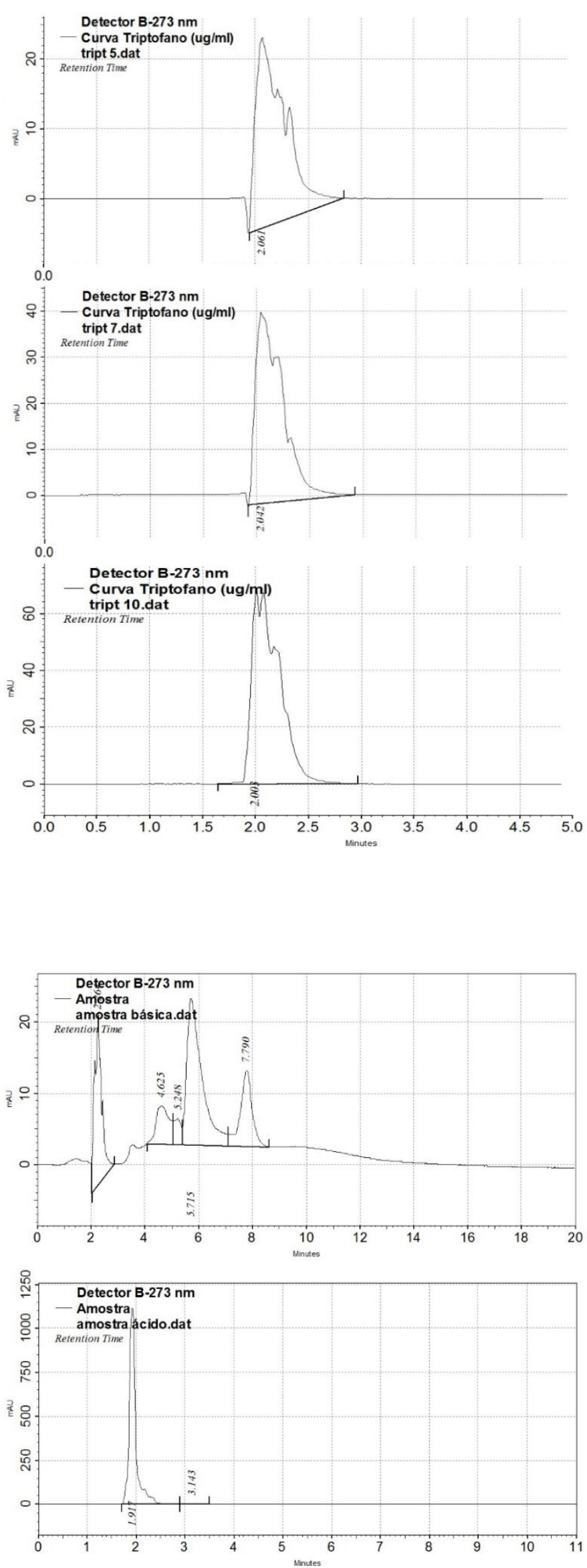

Figura 81. Cromatograma da reprodutibilidade dos picos atípicos das concentrações de triptofanao em soluções contendo 5,7 e $10 \mu \mathrm{g} \cdot \mathrm{mL}^{-1}$ de padrão.

Figura 82. Cromatograma da reprodutibilidade dos picos atípicos observados nas primeiras amostras de plasma injetadas. $\mathrm{O}$ painel superior apresenta a amostra preparada em meio básico e o painel inferior a amostra preparada utilizando HCL $0,5 \mathrm{M}$. 
Após estas tentativas, decidimos utilizar Ácido Perclórico 0,4M, o que aumentou sensivelmente a precisão desta técnica, principalmente pela ocorrência de um novo pico aos 6,489 min (Figura 83) assim como demonstrado anteriormente [73]. Como este pico apresentou sensibilidade as diferentes concentrações de TrP das soluções padrão (Figura 83) e uma reprodutibilidade satisfatória para amostras de plasma (Tabela 1), concluímos que a utilização de Ácido perclórico para a preparação das amostras era a mais adequada, permitindo que o presente estudo fosse concluído. 


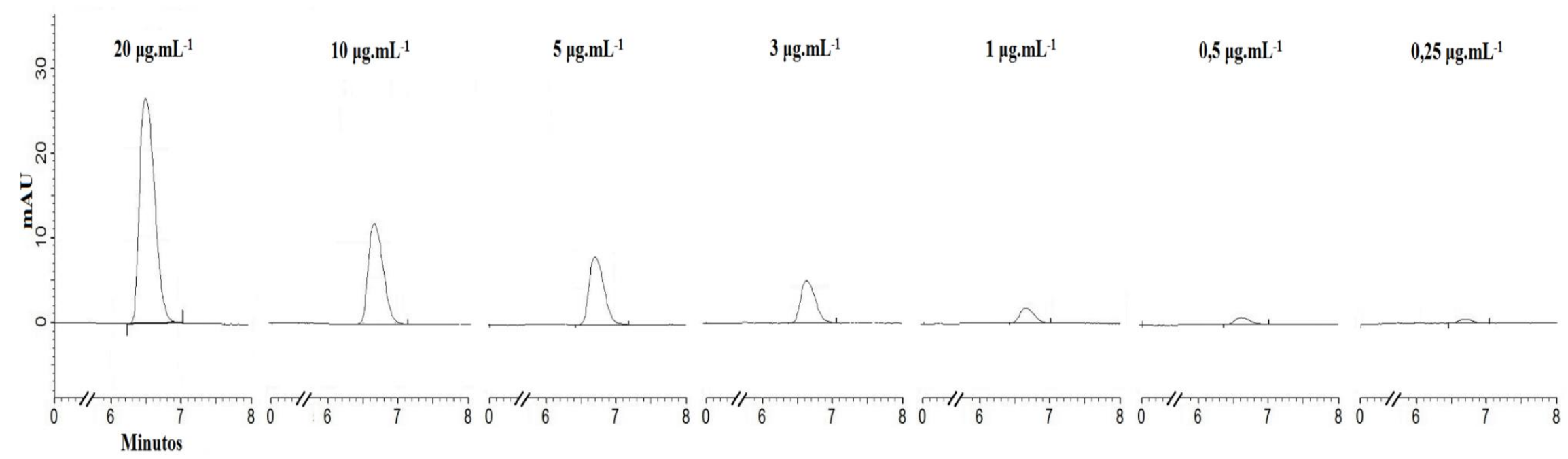

Figura 83. Comportamento cromatográfico dos picos de triptofano observados com diferentes concentrações em soluções padrão.

Tabela 1. Índices de reprodutibilidade de 14 amostras injetadas para a determinação das concentrações de triptofano.

\begin{tabular}{llllll}
\hline & Teste & Reteste & ET & CV & ICC \\
\hline Tempo de retenção (min) & $6,7 \pm 0,5$ & $6,8 \pm 0,2$ & 0,3 & 4,3 & 0,44 \\
Área do pico (mAU.min) & $118454 \pm 119206$ & $121275 \pm 122438$ & 3621 & 3,0 & $0,99 *$ \\
Triptofano ( $\left.\mu \mathrm{g} \cdot \mathrm{mL}^{-1}\right)$ & $5,6 \pm 5,9$ & $5,8 \pm 6,1$ & 0,2 & 3,3 & $0,99 *$ \\
\hline
\end{tabular}

Tempo de retenção: tempo em que o pico de triptofano emergiu no cromatograma; Área do pico: área observada abaixo do pico de triptofano;

Triptofano: concentração calculada a partir da reta de calibração construída entre a área e as diferentes soluções padrão* ICC significativa $(\mathrm{p}<0,05)$. 


\section{REFERÊNCIAS}

1. Ascensão, A., et al., Fisiologia da fadiga muscular. Delimitação conceptual, modelos de estudo e mecanismos de fadiga de origem central e periférica. Revista Portuguesa de Ciências do Desporto, 2003. 3(1): p. 108-123.

2. $\quad$ Fitts, R., Cellular mechanisms of muscle fatigue. Physiological reviews, 1994. 74(1): p. 49-94.

3. Enoka, R.M. and D.G. Stuart, Neurobiology of muscle fatigue. Journal of applied physiology, 1992. 72(5): p. 1631-1648.

4. Gandevia, S., Spinal and supraspinal factors in human muscle fatigue. Physiological reviews, 2001. 81(4): p. 1725-1789.

5. Costill, D.L., et al., Effects of repeated days of intensified training on muscle glycogen and swimming performance. Med Sci Sports Exerc, 1988. 20(3): p. 249-254.

6. Alghannam, A.F., et al., Impact of Muscle Glycogen Availability on the Capacity for Repeated Exercise in Man. Medicine and science in sports and exercise, 2016. 48(1): p. 123-131.

7. Ørtenblad, N., H. Westerblad, and J. Nielsen, Muscle glycogen stores and fatigue. The Journal of physiology, 2013. 591(18): p. 4405-4413.

8. Bergström, J. and E. Hultman, A study of the glycogen metabolism during exercise in man. Scandinavian journal of clinical and laboratory investigation, 1967. 19(3): p. 218-228.

9. Bergström, J., et al., Diet, muscle glycogen and physical performance. Acta Physiologica Scandinavica, 1967. 71(2-3): p. 140-150.

10. Gollnick, P., et al., Glycogen depletion pattern in human skeletal muscle fibers after heavy exercise. Journal of Applied Physiology, 1973. 34(5): p. 615-618.

11. Gollnick, P., et al., Glycogen depletion patterns in human skeletal muscle fibers after varying types and intensities of exercise, in Metabolic Adaptation to Prolonged Physical Exercise. 1975, Springer. p. 416421.

12. Gollnick, P., K. Piehl, and B. Saltin, Selective glycogen depletion pattern in human muscle fibres after exercise of varying intensity and at varying pedalling rates. The Journal of Physiology, 1974. 241(1): p. 45.

13. Green, H., How important is endogenous muscle glycogen to fatigue in prolonged exercise? Canadian journal of physiology and pharmacology, 1991. 69(2): p. 290-297.

14. Hansen, A.K., et al., Skeletal muscle adaptation: training twice every second day vs. training once daily. Journal of Applied Physiology, 2005. 98(1): p. 93-99.

15. Hargreaves, M., Exercise, muscle, and CHO metabolism. Scandinavian journal of medicine \& science in sports, 2015. 25(S4): p. 29-33.

16. Hermansen, L., E. Hultman, and B. Saltin, Muscle glycogen during prolonged severe exercise. Acta Physiologica Scandinavica, 1967. 71(2-3): p. 129-139.

17. Philp, A., M. Hargreaves, and K. Baar, More than a store: regulatory roles for glycogen in skeletal muscle adaptation to exercise. American Journal of Physiology-Endocrinology And Metabolism, 2012. 302(11): p. E1343-E1351.

18. Steensberg, A., et al., Muscle glycogen content and glucose uptake during exercise in humans: influence of prior exercise and dietary manipulation. The Journal of physiology, 2002. 541(1): p. 273-281.

19. Green, H., et al., Early muscular and metabolic adaptations to prolonged exercise training in humans. Journal of Applied Physiology, 1991. 70(5): p. 2032-2038.

20. Coyle, E.F., et al., Muscle glycogen utilization during prolonged strenuous exercise when fed carbohydrate. Journal of applied physiology, 1986. 61(1): p. 165-172.

21. Hearris, M., et al., Regulation of muscle glycogen metabolism during exercise: implications for endurance performance and training adaptations. Nutrients, 2018. 10(3): p. 298.

22. Chan, M.S., et al., Cytokine gene expression in human skeletal muscle during concentric contraction: evidence that IL-8, like IL-6, is influenced by glycogen availability. American Journal of PhysiologyRegulatory, Integrative and Comparative Physiology, 2004. 287(2): p. R322-R327.

23. Nieman, D.C., et al., Post-exercise skeletal muscle glycogen related to plasma cytokines and muscle IL6 protein content, but not muscle cytokine mRNA expression. Frontiers in Nutrition, 2015. 2: p. 27.

24. Steensberg, A., et al., Interleukin-6 production in contracting human skeletal muscle is influenced by preexercise muscle glycogen content. The Journal of physiology, 2001. 537(2): p. 633-639.

25. Meeusen, R. and P. Watson, Amino acids and the brain: do they play a role in" central fatigue"? International journal of sport nutrition and exercise metabolism, 2007. 17: p. S37. 
26. Pitsiladis, Y., et al., Hyperprolactinaemia during prolonged exercise in the heat: evidence for a centrally mediated component of fatigue in trained cyclists. Experimental physiology, 2002. 87(02): p. 215-226.

27. Meeusen, R., et al., Central fatigue. Sports Medicine, 2006. 36(10): p. 881-909.

28. Perrier, J.-F., MODULATION OF MOTONEURON ACTIVITY BY SEROTONIN. Current pharmaceutical design, 2013. 19(24): p. 4371-84.

29. Noakes, T., Physiological models to understand exercise fatigue and the adaptations that predict or enhance athletic performance. Scandinavian journal of medicine \& science in sports, 2000. 10(3): p. 123145.

30. Noakes, T.D., J.E. Peltonen, and H.K. Rusko, Evidence that a central governor regulates exercise performance during acute hypoxia and hyperoxia. Journal of Experimental Biology, 2001. 204(18): p. 3225-3234.

31. Lima-Silva, A.E., et al., Influence of high-and low-carbohydrate diet following glycogen-depleting exercise on heart rate variability and plasma catecholamines. Applied Physiology, Nutrition, and Metabolism, 2010. 35(4): p. 541-547.

32. Helge, J.W., E.A. Richter, and B. Kiens, Interaction of training and diet on metabolism and endurance during exercise in man. The Journal of physiology, 1996. 492(Pt 1): p. 293.

33. Havemann, L., et al., Fat adaptation followed by carbohydrate loading compromises high-intensity sprint performance. Journal of Applied Physiology, 2006. 100(1): p. 194-202.

34. Weltan, S.M., et al., Influence of muscle glycogen content on metabolic regulation. American Journal of Physiology-Endocrinology And Metabolism, 1998. 274(1): p. E72-E82.

35. Martin, V., et al., Central and peripheral contributions to neuromuscular fatigue induced by a 24-h treadmill run. Journal of applied physiology, 2010. 108(5): p. 1224-1233.

36. de Oliveira Pires, F., Thomas Kuhn's 'Structure of Scientific Revolutions' applied to exercise science paradigm shifts: example including the Central Governor Model. British journal of sports medicine, 2013. 47(11): p. 721-722.

37. Rauch, H., et al., A signalling role for muscle glycogen in the regulation of pace during prolonged exercise. British journal of sports medicine, 2005. 39(1): p. 34-38.

38. Laursen, P.B., Training for intense exercise performance: high-intensity or high-volume training? Scandinavian journal of medicine \& science in sports, 2010. 20(s2): p. 1-10.

39. Bastos-Silva, V.J., et al., Carbohydrate Mouth Rinse Maintains Muscle Electromyographic Activity and Increases Time to Exhaustion during Moderate but not High-Intensity Cycling Exercise. Nutrients, 2016. 8(3): p. 49.

40. Hawley, J.A., et al., Carbohydrate-loading and exercise performance. Sports medicine, 1997. 24(2): p. 73-81.

41. O'Leary, T., et al., Central and peripheral fatigue following non-exhaustive and exhaustive exercise of disparate metabolic demands. Scandinavian journal of medicine \& science in sports, 2015.

42. Carter, H., et al., Muscle glycogen depletion alters oxygen uptake kinetics during heavy exercise. Medicine and science in sports and exercise, 2004. 36(6): p. 965-972.

43. Shield, A. and S. Zhou, Assessing voluntary muscle activation with the twitch interpolation technique. Sports Medicine, 2004. 34(4): p. 253-267.

44. Cueva, A.S., et al., Normative data of cortical excitability measurements obtained by transcranial magnetic stimulation in healthy subjects. Neurophysiologie Clinique/Clinical Neurophysiology, 2016. 46(1): p. 43-51.

45. Goodall, S., et al., Augmented supraspinal fatigue following constant-load cycling in the heat. Scandinavian journal of medicine \& science in sports, 2015. 25(S1): p. 164-172.

46. Goodall, S., et al., Supraspinal fatigue after normoxic and hypoxic exercise in humans. The Journal of physiology, 2012. 590(11): p. 2767-2782.

47. Goodall, S., et al., Transcranial magnetic stimulation in sport science: a commentary. European journal of sport science, 2014. 14(sup1): p. S332-S340.

48. Hermsen, A., et al., Test-retest reliability of single and paired pulse transcranial magnetic stimulation parameters in healthy subjects. Journal of the Neurological Sciences, 2016.

49. Milioni, F., Associações entre, índices fisiológicos e fadiga neuromuscular com padrões de deslocamento e desempenho do chute de finalização no futsal. 2014.

50. Andrade, V.L.d., Alterações mecânicas e fisiológicas induzidas por um teste anaeróbio de esforços repetidos de alta intensidade, Universidade de São Paulo.

51. Andersen, P., et al., Dynamic knee extension as model for study of isolated exercising muscle in humans. Journal of Applied Physiology, 1985. 59(5): p. 1647-1653.

52. Hill, J.C. and I.S. Millán, Validation of musculoskeletal ultrasound to assess and quantify muscle 
glycogen content. A novel approach. The Physician and sportsmedicine, 2014. 42(3): p. 45-52.

53. Nieman, D.C., et al., Ultrasonic assessment of exercise-induced change in skeletal muscle glycogen content. BMC sports science, medicine and rehabilitation, 2015. 7(1): p. 1.

54. Areta, J.L. and W.G. Hopkins, Skeletal muscle glycogen content at rest and during endurance exercise in humans: a meta-analysis. Sports Medicine, 2018: p. 1-12.

55. Costill, D., et al., Effects of elevated plasma FFA and insulin on muscle glycogen usage during exercise. Journal of Applied Physiology, 1977. 43(4): p. 695-699.

56. Hargreaves, M., G. McCONELL, and J. Proietto, Influence of muscle glycogen on glycogenolysis and glucose uptake during exercise in humans. Journal of Applied Physiology, 1995. 78(1): p. 288-292.

57. Balsom, P.D., et al., High-intensity exercise and muscle glycogen availability in humans. Acta Physiologica Scandinavica, 1999. 165: p. 337-346.

58. Ivy, J., et al., Muscle glycogen synthesis after exercise: effect of time of carbohydrate ingestion. Journal of applied physiology, 1988. 64(4): p. 1480-1485.

59. Hermens, H.J., et al., European recommendations for surface electromyography. Roessingh Research and Development, 1999. 8(2): p. 13-54.

60. Milioni, F., et al., Futsal match-related fatigue affects running performance and neuromuscular parameters but not finishing kick speed or accuracy. Frontiers in physiology, 2016. 7: p. 518.

61. Girard, O., D.J. Bishop, and S. Racinais, Neuromuscular adjustments of the quadriceps muscle after repeated cycling sprints. PLoS One, 2013. 8(5): p. e61793.

62. Neyroud, D., et al., The effect of muscle fatigue on stimulus intensity requirements for central and peripheral fatigue quantification. Eur J Appl Physiol, 2014. 114(1): p. 205-15.

63. Allen, G., S. Gandevia, and D. McKenzie, Reliability of measurements of muscle strength and voluntary activation using twitch interpolation. Muscle \& nerve, 1995. 18(6): p. 593-600.

64. Hingst, J.R., Glucose Uptake and Glycogen Synthesis in Recovery from Exercise: Molecular Mechanisms Regulating the 'Set-Point'for Muscle Glucose Storag, 2016, Department of Nutrition, Exercise and Sports, Faculty of Science, University ....

65. Gavin, J.P., S.D. Myers, and M.E. Willems, Neuromuscular responses to mild-muscle damaging eccentric exercise in a low glycogen state. Journal of Electromyography and Kinesiology, 2015. 25(1): p. 53-60.

66. Greene, J., et al., State-of-the-Art Methods for Skeletal Muscle Glycogen Analysis in Athletes-The Need for Novel Non-Invasive Techniques. Biosensors, 2017. 7(1): p. 11.

67. Adams, J. and J. Koeslag, Carbohydrate homeostasis and post-exercise ketosis in trained and untrained rats. The Journal of physiology, 1988. 407(1): p. 453-461.

68. Alghannam, A.F., et al., Impact of muscle glycogen availability on the capacity for repeated exercise in man. Med Sci Sports Exerc, 2016. 48(1): p. 123-31.

69. Gruet, M., et al., Stimulation of the motor cortex and corticospinal tract to assess human muscle fatigue. Neuroscience, 2013. 231: p. 384-399.

70. Gruet, M., et al., Dynamics of corticospinal changes during and after high-intensity quadriceps exercise. Experimental physiology, 2014. 99(8): p. 1053-1064.

71. Souza, V.H., et al., Development and characterization of the InVesalius Navigator software for navigated transcranial magnetic stimulation. Journal of neuroscience methods, 2018. 309: p. 109-120.

72. Temesi, J., The use of transcranial magnetic stimulation in locomotor function: methodological issues and application to extreme exercise, 2013, Université Jean Monnet-Saint-Etienne.

73. Sultana, N., et al., Determination of tryptophan in raw materials, rat brain and human plasma by RPHPLC technique. Journal of chromatographic science, 2012. 50(6): p. 531-537.

74. Bergström, J. and E. Hultman, Muscle glycogen synthesis after exercise: an enhancing factor localized to the muscle cells in man. Nature, 1966. 210(5033): p. 309.

75. Greenhaff, P., M. Gleeson, and R. Maughan, The effects of diet on muscle pH and metabolism during high intensity exercise. European journal of applied physiology and occupational physiology, 1988. 57(5): p. 531-539.

76. Maughan, R. and D. Poole, The effects of a glycogen-loading regimen on the capacity to perform anaerobic exercise. European Journal of Applied Physiology and Occupational Physiology, 1981. 46(3): p. 211-219.

77. Henneman, E., G. Somjen, and D.O. Carpenter, Functional significance of cell size in spinal motoneurons. Journal of neurophysiology, 1965. 28(3): p. 560-580.

78. Nordlund, M.M., A. Thorstensson, and A.G. Cresswell, Central and peripheral contributions to fatigue in relation to level of activation during repeated maximal voluntary isometric plantar flexions. Journal of applied physiology, 2004. 
79. Jensen, J. and Y.-C. Lai, Regulation of muscle glycogen synthase phosphorylation and kinetic properties by insulin, exercise, adrenaline and role in insulin resistance. Archives of physiology and biochemistry, 2009. 115(1): p. 13-21.

80. Bergström, J., Percutaneous needle biopsy of skeletal muscle in physiological and clinical research. Scandinavian journal of clinical and laboratory investigation, 1975. 35(7): p. 609-616.

81. Tarnopolsky, M.A., et al., Suction-modified Bergström muscle biopsy technique: Experience with 13,500 procedures. Muscle \& nerve, 2011. 43(5): p. 716-725.

82. Goldsmith, E., S. Sprang, and R. Fletterick, Structure of maltoheptaose by difference Fourier methods and a model for glycogen. Journal of molecular biology, 1982. 156(2): p. 411-427.

83. Ivy, J.L., Muscle glycogen synthesis before and after exercise. Sports Medicine, 1991. 11(1): p. 6-19.

84. Ørtenblad, N., et al., Role of glycogen availability in sarcoplasmic reticulum Ca2+ kinetics in human skeletal muscle. The Journal of physiology, 2011. 589(3): p. 711-725.

85. Tsintzas, O.-K., et al., Carbohydrate ingestion and single muscle fiber glycogen metabolism during prolonged running in men. Journal of applied physiology, 1996. 81(2): p. 801-809.

86. Tsintzas, O.-K., et al., Carbohydrate ingestion and glycogen utilization in different muscle fibre types in man. The Journal of Physiology, 1995. 489(1): p. 243-250.

87. Wasserman, D.H., et al., The physiological regulation of glucose flux into muscle in vivo. Journal of Experimental Biology, 2011. 214(2): p. 254-262.

88. Skurat, A.V. and P.J. Roach, Phosphorylation of sites $3 a$ and $3 b$ (Ser640 and Ser644) in the control of rabbit muscle glycogen synthase. Journal of Biological Chemistry, 1995. 270(21): p. 12491-12497.

89. Skurat, A.V., et al., Rate-determining steps in the biosynthesis of glycogen in COS cells. Archives of biochemistry and biophysics, 1996. 328(2): p. 283-288.

90. Roach, P.J., Control of glycogen synthase by hierarchal protein phosphorylation. The FASEB Journal, 1990. 4(12): p. 2961-2968.

91. Roach, P.J., Glycogen and its metabolism. Current molecular medicine, 2002. 2(2): p. 101-120.

92. Bangsbo, J. and Y. Hellsten, Muscle blood flow and oxygen uptake in recovery from exercise. Acta Physiologica Scandinavica, 1998. 162(3): p. 305-312.

93. Price, T., D. Laurent, and K. Petersen, 13C/31P NMR studies on the role of glucose transport/phosphorylation in human glycogen supercompensation. International journal of sports medicine, 2003. 24(04): p. 238-244.

94. Gollnick, P.D., et al., Glycogen depletion patterns in human skeletal muscle fibers during prolonged work. Pflügers Archiv, 1973. 344(1): p. 1-12.

95. Meyer, F., et al., Control of Phosphorylase Activity in a Muscle Glycogen Particle I. ISOLATION AND CHARACTERIZATION OF THE PROTEIN-GLYCOGEN COMPLEX. Journal of Biological Chemistry, 1970. 245(24): p. 6642-6648.

96. CAUDWELL, F.B. and P. COHEN, Purification and subunit structure of glycogen-branching enzyme from rabbit skeletal muscle. European journal of biochemistry, 1980. 109(2): p. 391-394.

97. Heilmeyer, L.M., et al., Control of phosphorylase activity in a muscle glycogen particle II. Activation by calcium. Journal of Biological Chemistry, 1970. 245(24): p. 6649-6656.

98. Kobayashi, T., et al., Phosphorylation of mylein basic protein by glycogen phosphorylase kinase. FEBS letters, 1984. 169(2): p. 224-228.

99. Nakielny, S., D.G. CAMPBELL, and P. COHEN, The molecular mechanism by which adrenalin inhibits glycogen synthesis. European journal of biochemistry, 1991. 199(3): p. 713-722.

100. Howlett, R.A., et al., Regulation of skeletal muscle glycogen phosphorylase and PDH at varying exercise power outputs. American Journal of Physiology-Regulatory, Integrative and Comparative Physiology, 1998. 275(2): p. R418-R425.

101. Krogh, A. and J. Lindhard, The relative value of fat and carbohydrate as sources of muscular energy: with appendices on the correlation between standard metabolism and the respiratory quotient during rest and work. Biochemical Journal, 1920. 14(3-4): p. 290.

102. Gollnick, P., Energy metabolism and prolonged exercise. Perspectives in exercise science and sports medicine, 1988. 1: p. 1-42.

103. Impey, S.G., et al., Fuel for the work required: a theoretical framework for carbohydrate periodization and the glycogen threshold hypothesis. Sports Medicine, 2018. 48(5): p. 1031-1048.

104. Greenhaff, P., M. Gleeson, and R. Maughan, The effects of dietary manipulation on blood acid-base status and the performance of high intensity exercise. European journal of applied physiology and occupational physiology, 1987. 56(3): p. 331-337.

105. Greenhaff, P., et al., Dietary composition and acid-base status: limiting factors in the performance of maximal exercise in man? European journal of applied physiology and occupational physiology, 1987. 
56(4): p. 444-450.

106. Lamb, D.R., A.C. Snyder, and T.S. Baur, Muscle glycogen loading with a liquid carbohydrate supplement. International journal of sport nutrition, 1991. 1(1): p. 52-60.

107. Tarnopolsky, M., et al., Carbohydrate loading and metabolism during exercise in men and women. Journal of applied Physiology, 1995. 78(4): p. 1360-1368.

108. Hawley, J.A., G.S. Palmer, and T.D. Noakes, Effects of 3 days of carbohydrate supplementation on muscle glycogen content and utilisation during a 1-h cycling performance. European journal of applied physiology and occupational physiology, 1997. 75(5): p. 407-412.

109. Madsen, K., et al., Carbohydrate supercompensation and muscle glycogen utilization during exhaustive running in highly trained athletes. European journal of applied physiology and occupational physiology, 1990. 61(5-6): p. 467-472.

110. B., A., B. J., and B. J., Human muscle glycogen content and capacity for prolonged exercise after different diets Foersvarsmedicin 1967: p. 85-99.

111. Bosch, A.N., S.C. Dennis, and T.D. Noakes, Influence of carbohydrate ingestion on fuel substrate turnover and oxidation during prolonged exercise. Journal of Applied Physiology, 1994. 76(6): p. 23642372.

112. Goulet, E.D. and M.D. Hoffman, Impact of Ad Libitum Versus Programmed Drinking on Endurance Performance: A Systematic Review with Meta-Analysis. Sports Medicine, 2019: p. 1-12.

113. Kimber, N.E., et al., Skeletal muscle fat and carbohydrate metabolism during recovery from glycogendepleting exercise in humans. The Journal of physiology, 2003. 548(3): p. 919-927.

114. Kiens, B. and E.A. Richter, Utilization of skeletal muscle triacylglycerol during postexercise recovery in humans. American Journal of Physiology-Endocrinology And Metabolism, 1998. 275(2): p. E332-E337.

115. Bangsbo, J., M. Kjær, and Y. Hellsten, Bengt Saltin (1935-2014). The Journal of physiology, 2014. 592(23): p. 5149-5151.

116. Booth, F., Muscle adaptation to exercise: New Saltin's paradigms. Scandinavian journal of medicine \& science in sports, 2015. 25(S4): p. 49-52.

117. Greenhaff, P.L., Milestones in human physiology: muscle energy metabolism and blood flow during contraction. The Journal of physiology, 2003. 551(2): p. 397-399.

118. Winter, D.A., Biomechanics and motor control of human movement. 2009: John Wiley \& Sons.

119. David Halliday, R. Resnick, and J. Walker, Fundamentos de Física: Mecânica, 2009, LTC.

120. Brown, S.P., W.C. Miller, and J.M. Eason, Exercise physiology: basis of human movement in health and disease. 2006: Lippincott Williams \& Wilkins.

121. Ferguson, R.A., et al., Total power output generated during dynamic knee extensor exercise at different contraction frequencies. Journal of Applied Physiology, 2000. 89(5): p. 1912-1918.

122. Foster, C., et al., A new approach to monitoring exercise training. The Journal of Strength \& Conditioning Research, 2001. 15(1): p. 109-115.

123. Kuipers, H., et al., Variability of aerobic performance in the laboratory and its physiologic correlates. International journal of sports medicine, 1985. 6(4): p. 197-201.

124. Beaver, W.L., K. Wasserman, and B.J. Whipp, A new method for detecting anaerobic threshold by gas exchange. Journal of applied physiology, 1986. 60(6): p. 2020-2027.

125. Takano, N., Respiratory compensation point during incremental exercise as related to hypoxic ventilatory chemosensitivity and lactate increase in man. The Japanese journal of physiology, 2000. 50(4): p. 449455 .

126. Bertuzzi, R., et al., GEDAE-LaB: A Free Software to Calculate the Energy System Contributions during Exercise. PloS one, 2016. 11(1): p. e0145733.

127. Beneke, R., R. Leithäuser, and M. Hütler, Dependence of the maximal lactate steady state on the motor pattern of exercise. British Journal of Sports Medicine, 2001. 35(3): p. 192-196.

128. Kuipers, H., et al., Effects of stage duration in incremental running tests on physiological variables. International journal of sports medicine, 2003. 24(07): p. 486-491.

129. Machado, F.A., et al., Effect of stage duration on maximal heart rate and post-exercise blood lactate concentration during incremental treadmill tests. Journal of Science and Medicine in Sport, 2013. 16(3): p. 276-280.

130. Machado, F.A., et al., Incremental test design, peak 'aerobic'running speed and endurance performance in runners. Journal of science and medicine in sport, 2013. 16(6): p. 577-582.

131. Peserico, C.S., A.M. Zagatto, and F.A. Machado, Reliability of peak running speeds obtained from different incremental treadmill protocols. Journal of sports sciences, 2014. 32(10): p. 993-1000.

132. Bassett, D.R. and E.T. Howley, Limiting factors for maximum oxygen uptake and determinants of endurance performance. Medicine and science in sports and exercise, 2000. 32(1): p. 70-84. 
133. Binder, R.K., et al., Methodological approach to the first and second lactate threshold in incremental cardiopulmonary exercise testing. European journal of cardiovascular prevention \& rehabilitation, 2008. 15(6): p. 726-734

134. Hill, D.W., D.C. Poole, and J.C. Smith, The relationship between power and the time to achieve. VO (2max). Medicine and science in sports and exercise, 2002. 34(4): p. 709-714.

135. Dubois, M., et al., Colorimetric method for determination of sugars and related substances. Analytical chemistry, 1956. 28(3): p. 350-356.

136. BONATO, P.S., C. Collins, and G. Braga, Fundamentos de Cromatografia. Campinas, SP: Editora da Unicamp, 2006. 